University of Louisville

ThinkIR: The University of Louisville's Institutional Repository

Electronic Theses and Dissertations

$12-2003$

\title{
Synthesis of peptides with hydroxamic acid side chain appendages.
}

Yingchuan Susan Sun 1975-

University of Louisville

Follow this and additional works at: https://ir.library.louisville.edu/etd

\section{Recommended Citation}

Sun, Yingchuan Susan 1975-, "Synthesis of peptides with hydroxamic acid side chain appendages." (2003). Electronic Theses and Dissertations. Paper 1407.

https://doi.org/10.18297/etd/1407

This Master's Thesis is brought to you for free and open access by ThinkIR: The University of Louisville's Institutional Repository. It has been accepted for inclusion in Electronic Theses and Dissertations by an authorized administrator of ThinkIR: The University of Louisville's Institutional Repository. This title appears here courtesy of the author, who has retained all other copyrights. For more information, please contact thinkir@louisville.edu. 


\title{
SYNTHESIS OF PEPTIDES WITH HYDROXAMIC ACID SIDE CHAIN APPENDAGES
}

\author{
By Yingchuan Susan Sun \\ B.S., China Pharmaceutical University, 1997
}

\begin{abstract}
A Thesis
Submitted to the Faculty of the

Graduate School of the University of Louisville

in Partial Fulfillment of the Requirements

for the Degree of
\end{abstract}

Master of Science

Department of Chemistry

University of Louisville

Louiville, Kentucky

December, 2003 
SYNTHESIS OF PEPTIDES WITH HYDROXAMIC ACID SIDE CHAIN APPENDAGES

\author{
By \\ Yingchuan Susan Sun
}

A Thesis Approved on

April 14, 2003

By the Following Thesis Committee:

Arno F. Spatola (deceased)

Thesis Director

Chairman 
Copyright 2003 by Yingchuan Susan Sun

All rights reserved 


\title{
DEDICATION
}

This thesis is dedicated to my graduate advisor

\author{
Dr. Arno Spatola
}

who spent his whole life in teaching me and other students principles of chemical science 


\section{ACKNOWLEDGEMENTS}

The author would like to express her gratitude and appreciation to her mentor, Dr. Arno F. Spatola, for his guidance, advice, encouragement, and inspiration throughout her entire graduate student program. His life-long dedication to career and obligation to students and family is greatly acknowledged and appreciated. The author is also grateful to other members of her master of science committee, Dr. Robert Buchanan, Dr. William Pierce and Dr. K. Grant Taylor for their time and effort in evaluation of this thesis.

The effort of our collaborators, Ned Smith, lab manager and Dr. William Pierce, director of the mass spectrometry core laboratory at the University of Louisville, is gratefully acknowledged. It was through their work that the electrospray ionization-mass spectrometry data was obtained. The author also gives thanks to Dr. Hynda Kleinman, Chief, Cell Biology Section, National Institute of Dental and Craniofacial Research, NIH, who provided biological data for this project. She would also like to thank the Graduate School for financial support through the course of these studies.

Many laboratory colleagues are acknowledged here for their advice, encouragement and friendships, and they are Dr. Peter Romanovskis, Dr. David Vogel, Dr. Florence Brunel, Ms. Anne-Marie Leudc, Mr. Amit Galande, Ms. Natali Richter, Ms. Elizabeth Romaine-Schmidt and Ms. Melody Grapperhaus who helped the author in preparing a poster and slides. At last the author would like to show her profound gratitude to her parents for their love, support and encouragement. 


\begin{abstract}
SYNTHESIS OF PEPTIDES WITH HYDROXAMIC ACID SIDE CHAIN

APPENDAGES

Yingchuan Susan Sun
\end{abstract}

April 14, 2003

Chapter 1 detailed the synthesis method of hydroxamate peptides derivatives of pentapeptide Ac-PHSXX'-N-NH$H_{2}$ by solid phase hydroxamate peptide synthesis method. The glutamic acid / aspartic acid side chain was modified to hydroxamic acid by on resin $\mathrm{N}-\mathrm{C}$ coupling. The hydroxamate benzyl protecting group was removed during HF cleavage. In Chapter 2 a novel multiple hydroxamic acid peptide siderophore was prepared and the metal binding activity of these peptides was studied by ESI-MS and MS/MS. Siderophore peptide Ac-Gly $-\mathrm{Glu}_{2}(\mathrm{NHOH})-\mathrm{D}-\mathrm{Pro}_{3}-\mathrm{Gly}_{4}-\mathrm{Glu}_{5}(\mathrm{NHOH})-\mathrm{D}-\mathrm{Pro}_{6}-\mathrm{NH}_{2}$ was found to have significant preference to $\mathrm{Fe}(\mathrm{III})$ over $\mathrm{Zn}(\mathrm{II})$ and $\mathrm{Ni}(\mathrm{II})$, while the natural peptide analogue Ac-Gly $-\mathrm{Glu}_{2}-\mathrm{D}-\mathrm{Pro}_{3}-\mathrm{Gly}_{4}-\mathrm{Glu}_{5}-\mathrm{D}-\mathrm{Pro}_{6}-\mathrm{NH}_{2}$ did not show any obvious preference in these metal ions. The study of these multi hydroxamate ligands metal coordination revealed that the C-terminal binding site $\left(\mathrm{Glu}_{5}(\mathrm{NHOH})\right)$ has the stronger chelation capability than the $\mathrm{N}$ terminal $\left(\mathrm{Glu}_{2}(\mathrm{NHOH})\right)$ metal binding site and the amide bonds between glutamic acid and proline were identified as the most fragile bonds by MS/MS study. 


\section{TABLE OF CONTENTS}

\section{PAGE}

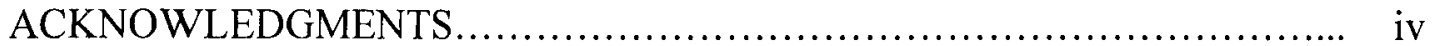

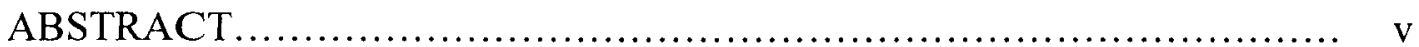

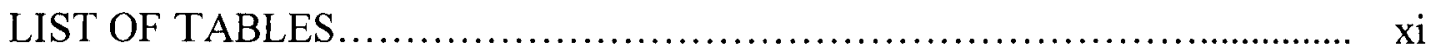

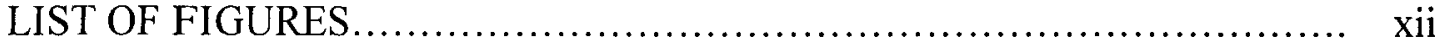

Chapter 1: Design an Synthesis of the Hydroxamic Acid Variants of Antitumorigenic and Antimetastatic Hydroxamate Based Ac-PHSXX'$\mathrm{NH}_{2}$ Sequences........................................... 1

A. Introduction..................................................... 1

1. Biological Importance of Peptide PHSRN ..................... 1

2. Preparation of HydroxamicAcid............................... 7

B. Research Objectives......................................... 12

C. Results and Discussion............................................. 13

1. Synthesis of Amino Hydroxamate Building Blocks............... 13

2. Attempted Synthesis of Peptides Using a Protected Hydroxamic Acid- Containing Amino Acid as a Preformed Building Block....... 16

3. Solid Phase Synthesis of Side Chain Hydroxamic Acid Peptides.... 17

4. Aspartimide Inhibition Study of Ac-PHSD(NHOH)N-NH $\mathrm{NH}_{2 \ldots \ldots \ldots \ldots . . .2} 21$ 
5. Parallel Synthesis of Ac-PHSXX'- $\mathrm{NH}_{2}$ Peptides.................. 30

6. Biological activity tests of peptide analogues Ac-PHSXX'N-NH ${ }_{2} \ldots 31$

D. Conclusion................................................... 34

E. Experimental Section............................................ 35

1. Preparation of Boc-Asp(NHOBn)-OFm and Boc-Glu(NHOBn)-

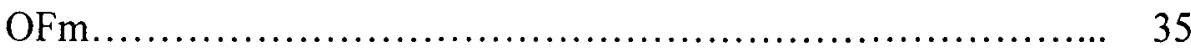

(1). Preparation of Boc-Asp-OH............................. 35

(2). Preparation of Boc-Aspartic Acid Anhydride................ 36

(3). Preparation of Boc-Asp-OFm.......................... 37

(4). Preparation of Boc-Glu(OBn)-OFm.................... 37

(5). Preparation of Boc-Glu-OFm........................... 38

(6). Preparation of Boc-Asp(NHOBn)-OFm.................. 39

(7). Preparation of Boc-Glu(NHOBn)-OFm.................. 39

2. Preparation of Boc-Asp(NHOBn)-OH and Boc-Glu(NHOBn)-OH.. $\quad 40$

(1). Preparation of Boc-Asp(NHOBn)-OH.................... 40

(2). Preparation of Boc-Glu(NHOBn)-OH..................... 41

3. Preparation of Ac-PHSXX'- $\mathrm{NH}_{2}$ sequences..................... 43

(1). Preparation of Ac-Pro-His-Ser-Arg-Asn- $\mathrm{NH}_{2} \ldots \ldots \ldots \ldots \ldots \ldots$

(2). Preparation of Ac-Pro-His-Ser-Cys-Asn- $\mathrm{NH}_{2} \ldots \ldots \ldots \ldots \ldots \ldots . .44$

(3). Preparation of Ac-Pro-His-Ser-Ser-Asn- $\mathrm{NH}_{2} \ldots \ldots \ldots \ldots \ldots \ldots \ldots .45$

(4). Parallel Synthesis of Ac-Pro-His-Ser-Asp-Asn- $\mathrm{NH}_{2}$, Ac-Pro-His-Ser-Asp- Phe-NH ${ }_{2}$, Ac-Pro-His-Ser-Arg-Phe$\mathrm{NH}_{2}$, Ac-Pro-His-Ser-Arg-Try-NH $\mathrm{N}_{2}$, Ac-Pro-His-Ser-Cys- 
Phe- $\mathrm{NH}_{2}$ and Ac-Pro-His-Ser-Cys-Tyr- $\mathrm{NH}_{2} \ldots \ldots \ldots \ldots \ldots \ldots . \ldots 4$

(5). Preparation of Ac-Pro-His-Ser-Glu(NHOH)-Leu- $\mathrm{NH}_{2} \ldots \ldots \ldots .49$

(6). Preparation of Ac-Pro-His-Ser-Glu(NHOH)-Asn- $\mathrm{NH}_{2} \ldots \ldots \ldots .50$

(7). Preparation of Ac-Pro-His-Ser-Asp(NHOH)-Asn- $\mathrm{NH}_{2} \ldots \ldots \ldots . .51$

Chapter II: Synthesis and Metal Binding Studies of Peptides Siderophore

Analogues..................................................... 52

A. Introduction...................................................... 52

1. General Introduction to Siderophores........................ 52

2. Molecular Diversity of Siderophores......................... 54

(1). Hydroxamate Siderophores............................... 54

(2). Phenolate Siderophores............................... 55

(3). Mixed Metal Binding Sites Siderophores................... 56

(4). Carboxylate Siderophores.............................. 58

(5). Peptide Siderophores.................................. 59

3. Siderophore Detection....................................... 61

4. Methods for Metal Binding Assay ............................. 61

(1). Electron Spray Ionization- Mass Spectrometry (ESI-MS)..... 62

(2). Tandem Mass Spectrometry (MS/MS) ................... 63

(3). Matrix Assisted Laser Desorption Ionization - Time of Flight Mass Spectrometry (MALDI-TOF MS) ................... 64

B. Research Objectives......................................... 66

C. Results and Discussion........................................ 66

1. Peptide Synthesis........................................... 66 
2. Metal Binding Study with Peptide E (Ac-Gly ${ }_{1}-\mathrm{Glu}_{2}-\mathrm{D}-\mathrm{Pro}_{3}-\mathrm{Gly}_{4}-$ $\mathrm{Glu}_{5}-\mathrm{D}-\mathrm{Pro}_{6}-\mathrm{NH}_{2}$ ) Using MALDI-TOF MS

3. Metal Binding Study of Peptide E (Ac-Gly $-\mathrm{Glu}_{2}-\mathrm{D}-\mathrm{Pro}_{3}-\mathrm{Gly}_{4}-$ $\mathrm{Glu}_{5}$-D-Pro 6 - $\mathrm{NH}_{2}$ ) with ESI-MS

(1).Peptide E Binding with Single Metal Studies. 72

(2).Peptide E Ligand Competitive Metal Binding Studies 74

(3).Peptide E · Metal Ion Complexes Structures. 76

4. Metal Binding Study of Peptide H (Ac-Gly ${ }_{1}-\mathrm{Glu}_{2}(\mathrm{NHOH})-\mathrm{D}-\mathrm{Pro}_{3}-$ $\mathrm{Gly}_{4}-\mathrm{Glu}_{5}(\mathrm{NHOH})-\mathrm{D}-\mathrm{Pro}_{6}-\mathrm{NH}_{2}$ ) using ESI-MS. 89

5. Peptide Fragmentation (Tandem MS/ MS). 96

6. Peptide $\mathrm{H} \cdot$ Metal Complexes Fragmentation. 115

D. Conclusion.

E. Experimental Section.

1. Synthesis of Ac-Gly-Glu-D-Pro-Gly-Glu-D-Pro-NH 130

(1). Preparation of Boc-D-Pro-MBHA resin. 130

(2). Preparation of Gly-Glu-D-Pro-MBHA resin.

(3). Preparation of Ac-Gly-Glu-D-Pro-Gly-Glu-D-Pro-MBHA resin 131

(4). Preparation of Ac-Gly-Glu-D-Pro-Gly-Glu-D-Pro- $\mathrm{NH}_{2}$ 131

2. Preparation of Ac-Gly-Glu(NHOH)-D-Pro-Gly-Glu(NHOH)-D-

Pro- $\mathrm{NH}_{2}$

(1). Preparation of Fmoc-Gly-Glu(O-tBu)-D-Pro- Gly-Glu(OtBu)-D-Pro-MBHA resin. 
(2). Preparation of Ac-Gly-Glu( $(\mathrm{O}-\mathrm{B} u)-\mathrm{D}-\mathrm{Pro}-\mathrm{Gly}-\mathrm{Glu}(\mathrm{O}-\mathrm{t} \mathrm{Bu})$ D-Pro- MBHA resin.

(3). Preparation of Ac-Gly-Glu(NHOBn)-D-Pro-GlyGlu(NHOBn)-D-Pro-MBHA resin.

(4). Preparation of Ac-Gly-Glu(NHOH)-D-Pro-Gly-

Glu(NHOH)-D-Pro- $\mathrm{NH}_{2}$

3 General Procedure for Metal Binding Studies.

References.

Appendix: Glossary of Abbreviation. 145

Curriculum Vitae. 150 


\section{LIST OF TABLES}

TABLE

PAGE

1

Preparation of hydroxamic acids by the acylation of

hydroxylamine and derivatives

2

Solid phase synthesis of side chain peptide hydroxamic acids

by following the peptide synthesis method in Figure 11

Summary of Ac-PHSXX'- $\mathrm{NH}_{2}$ peptides analogues in solid

solid phase peptide synthesis Boc chemistry

Ac-PHSXX'- $\mathrm{NH}_{2}$ peptides ex vivo ring angiogenesis assay

$(200 \mu \mathrm{g} / \mathrm{mL}$ at $24 \mathrm{~h}$ and $48 \mathrm{~h})$

Solid phase peptide synthesis protocol

Boc-amino acid building block used in parallel synthesis

peptide $7,8,9,10,11$ and 12

Peptide $\mathrm{E}$ binding with mixed metal perchlorates

Peptide Ac-Gly-Glu-dPro-Gly-Glu-dPro- $\mathrm{NH}_{2}$ metal binding

assay in individual test by ESI-MS

Using ESI-MS to assess peptide $\mathrm{H}$ metal binding in competition experiment

ESI-MS data from CID individual fragments of peptide $\mathrm{H}$

along with the metal (Ni(II), $\mathrm{Zn}(\mathrm{II})$ and $\mathrm{Fe}(\mathrm{III}))$ adducts 


\section{LIST OF FIGURES}

PAGE

Figure 1 A model for FN9-10 binding to $\alpha 5 \beta$ lintegrin 5

Figure 2 Three-dimensional structure of FN9-10 5

$\begin{array}{lll}\text { Figure } 3 & \text { Synthetic fibronectin peptides with different functions } & 6\end{array}$

Figure 4 Preparation of aminoxymethyl-Wang resin via Whittaker's 11 protocol

Figure $5 \quad$ SASRIN resin with $\mathrm{ONH}_{2}$ anchor

Figure 6 Hydroxamate aspartic acid and glutamic acid building blocks

Figure $7 \quad$ Synthesis of Boc-Asp-OFm

Figure $8 \quad$ Synthesis of Boc-Glu-OFm

Figure 9 Synthesis of Boc-Asp(NHOBn)-OH and Boc-Glu(NHOBn)-

$\mathrm{OH}$

Figure 10 Attempted coupling the building block to peptide chain

Figure 11 Preparation of Ac-PHSE(NHOH)N-NH

Figure 12 Side product in the preparation of Ac-Pro-His-SerAsp(NHOH)-Asn- $\mathrm{NH}_{2}$

Figure 13 Mechanism of aspartimide formation

Figure 14 Acid catalyzed aspartimide formation 
Figure 15 Base catalyzed aspartimide formation

Figure 16 Aspartimde formation in N-C coupling (path 1) and in peptide chain prolongation (path 2)

Figure 17 Backbone protecting group Hmb

Figure 18 New strategies to inhibit aspartimide formation using HMFS linker or Mpe ester

Figure 19 Boc-Asn(Xan)-OH

Figure 20 Modified methodology to prepare Ac-PHSD(NHOH)N-NH

Figure $21 \quad$ Structure of Desferrioxamine B

Figure 22 Structure of Enterobactin

Figure 23 Structure of Pyoverdin, chromophores of pyoverdin, 57 azotobactin and ferribactin

Figure $24 \quad$ Structure of Mycobactin

Figure 25 Structure of rhizoferrin

Figure $26 \quad$ Structure of coprogen

Figure 27 Ligand site of agrobactin, parabactin and fluvabactin

Figure $28 \quad$ Structure of peptide $\mathrm{E}$ and peptide $\mathrm{H}$

Figure 29 Synthesis method of peptide $\mathrm{H}$

Figure 30 Metal binding modes of peptide $\mathrm{E}$ with $\mathrm{M}^{2+}\left(\mathrm{Zn}^{2+}\right.$ or $\left.\mathrm{Ni}^{2+}\right)$ and 70 $\mathrm{Fe}^{3+}$

Figure 31 MALDI-MS study of peptide E (spectrum d) and peptide E with single metal ion (spectrum a-c) 
Figure 33 Metal binding modes of carboxylate ligand

Figure 34 Proposed Structure of peptide E - metal (ML) complexes (M: $\mathrm{Ni}^{2+}$ or $\mathrm{Zn}^{2+} ; \mathrm{L}:$ Ac-Gly-Glu- ${ }_{\mathrm{d}}$ Pro-Gly-Glu- ${ }_{\mathrm{d}} \mathrm{Pro}-\mathrm{NH}_{2}$ )

Figure 35 Proposed equilibrated structures of sandwich complex peptide

$\mathrm{E} \cdot \mathrm{Ni} \cdot$ peptide $\mathrm{E}(\mathrm{Ni}$ adopts the tetrahedral structure)

Figure 36 Alternative proposed structure of sandwich complex peptide $\mathrm{E}$

$\cdot \mathrm{Ni} \cdot$ peptide $\mathrm{E}$ (Ni adopts the octahedral structure)

Figure 37 Proposed coordination structure of peptide E $\cdot$ Fe (III) complex

Figure 38 ESI-MS spectra of peptide $\mathrm{E} \cdot \mathrm{Ni}^{2+}$ complex

Figure 39 ESI-MS spectrum of peptide $\mathrm{E} \cdot \mathrm{Ni}^{2+}$ complex (higher mass region)

Figure $40 \quad$ ESI-MS spectrum of peptide $\mathrm{E} \cdot \mathrm{Zn}^{2+}$ complex

Figure $41 \quad$ ESI-MS spectrum of peptide $\mathrm{E} \cdot \mathrm{Zn}^{2+}$ complex

(higher mass region)

Figure 42 ESI-MS of peptide $\mathrm{E} \cdot \mathrm{Fe}^{3+}$ complex

Figure 43 Peptide E with $\mathrm{Fe}\left(\mathrm{ClO}_{4}\right)_{3}, \mathrm{Ni}\left(\mathrm{ClO}_{4}\right)_{2}$ and $\mathrm{Zn}\left(\mathrm{ClO}_{4}\right)_{2}$

(Spectrum a-e)

Figure 44 Metal binding selectivity test with metal mixtures in different ratios

Figure 45 Metal binding selectivity test with metal mixtures in the concentration ratio of Peptide $\mathrm{H}: \mathrm{Fe}^{3+}: \mathrm{Ni}^{2+}: \mathrm{Zn}^{2+}=1: 1: 10: 10$

Figure 46 Metal binding selectivity comparison study of peptide $\mathrm{H}$ with 
and without $\mathrm{Fe}$ (III)

Figure 47 ESI-MS of Peptide H-Fe-Ni-Zn (1:1:1:1) at $\mathrm{pH} \sim 5$ vs $\mathrm{pH} 2$

$\begin{array}{lll}\text { Figure } 48 & \text { Peptide fragment nomination } & 97\end{array}$

Figure 49 Daughters of peptide $\mathrm{E}(\mathrm{m} / \mathrm{z}=626.2)$

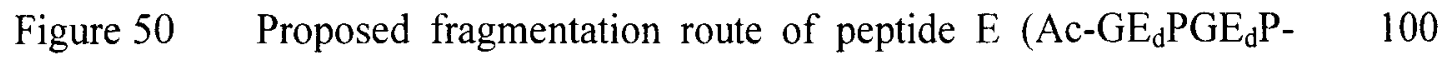
$\mathrm{NH}_{2}$ )

$\begin{array}{lll}\text { Figure } 51 \quad \text { Proposed double cleavage route of peptide E } & 101\end{array}$

Figure 52 ESI-MS data for peptide H, with varying ionization voltages 103 providing fragments for MS/ MS analysis.

Figure 53 ESI-MS study of peptide $\mathrm{H}$ and the CID experiment of the 104 peak of [peptide $\mathrm{H}+\mathrm{H}]^{+}$

Figure 54 Proposed fragmentation path of peptide $\mathrm{H}$ to generate fragment

2 through C-terminal cleavage

Figure 55 Proposed fragmentation path of peptide $\mathrm{H}$ to generate fragment 106

3 through side chain cyclization

Figure 56 Proposed fragmentation path of peptide $\mathrm{H}$ to generate fragment 107

6 and 12 through cleavage between $\mathrm{E}_{2}(\mathrm{NHOH})$ and $\mathrm{P}_{3}$ and fragment 8 through fragment 6 side chain cyclization

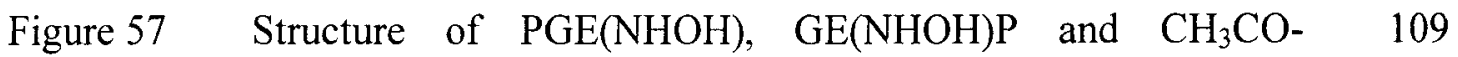
$\mathrm{E}(\mathrm{NHOH}) \mathrm{P}-\mathrm{NH}_{2}$

Figure 58 Fragment $10(\mathrm{~m} / \mathrm{z}=299)$ in MS/MS study

Figure 59 Proposed fragmentation path to give fragment ion with a mass of 299 
Figure 60 CID study of molecular ion $(\mathrm{m} / \mathrm{z}=701)$

Figure 61 Possible structures of molecular ion with the mass of 701

Figure 62 Proposed fragmentation route for peptide $\mathrm{H} \cdot \mathrm{M}$ (II) complex

$$
\text { (L: free peptide H, M: Ni or Zn) }
$$

Figure 63 Continued Proposed Fragmentation route for peptide $\mathrm{H} \cdot \mathrm{M}(\mathrm{II})$ complex (M: Ni or Zn)

Figure 64 ESI-MS and MS/MS study of peptide $\mathrm{H} \cdot \mathrm{Ni}(\mathrm{II})$ vs MS/MS study of free peptide $\mathrm{H}$

Figure $65 \quad$ ESI-MS and MS/MS study of peptide $\mathrm{H} \cdot \mathrm{Zn}$ (II)

Figure $66 \quad$ ESI-MS study of peptide $\mathrm{H} \cdot \mathrm{Fe}(\mathrm{III})$

Figure 67 Proposed structure of peptide $\mathrm{H} \cdot \mathrm{Fe}(\mathrm{III})$

Figure $68 \quad$ M/MS study of peak at $707 v s$ peak at 709

Figure 69 Proposed structure of peptide $\mathrm{H}(\mathrm{L}) \cdot \mathrm{Fe}^{3+}$ and its fragments 


\section{CHAPTER I}

\section{DESIGN AND SYNTHESIS OF HYDROXAMIC ACID VARIANTS OF ANTI- TUMORIGENIC AND ANTIMETASTATIC AC-PHSXX'-NH2 SEQUENCES}

\section{A Introduction}

\section{Biological Importance of Peptide PHSRN/ PHSCN}

The adhesive protein fibronectin (FN) is abundant in extracellular matrix of many cell types and plays important roles in a variety of biological processes. FNs have been shown to be involved in cell adhesion, cell morphology, thrombosis, cell migration, and embryonic differentiation (Hynes, 1990). FNs interact with cells using specific domains that are bound by specific cell surface receptors. For example, FNs have nearly a dozen cell-binding sites that can be recognized and are bound by cell-surface integrin, and this process mediates the adhesion of cells to $\mathrm{FN}$ in the extracellular matrix. One of the best characterized integrin-ligand interactions is $\alpha_{5} \beta_{1}$ binding to fibronectin (Figure 1).

The cell-binding domain of fibronectin has been the most extensively studied region among the many sites in extracellular matrix proteins that are known to mediate cell adhesion and migration (Hynes, 1990) (Pierschbacher and Ruoslahti, 1984). This region consists of repeating units, approximately 90 amino acid residues in length, termed FN type III repeats (Kornblihtt, 1985). The short polypeptide sequence RGD, which is located in the $10^{\text {th }}$ type III repeating unit of FN, has been shown to be a key binding site 
for $\alpha_{5} \beta_{1}$ integrin (Pierschbacher and Ruoslahti, 1984). But a second fragment, the pentapeptide PHSRN, found in the FN III domain 9 (FN 9), also contributes importantly to adhesion (Aota, 1994). This region has the potential to enhance overall binding to the integrin, and has therefore been termed as a synergy site. It bound only to the $\alpha_{5}$ domain of integrin, while RGD binds both $\alpha_{5}$ and $\beta_{1}$ domains.

In 1996, Leahy, Aukhil and Erickson determined the $2.0 \AA$ crystal structure of a fragment of human fibronectin encompassing the seventh through the RGD-containing tenth type III repeats (FN 7-10). The cell-binding RGD loop is well-ordered in this structure and extends $\sim 10 \AA$ away from the FN 7-10 core. The X-ray structure also revealed that an unusually small rotation between domains 9 and 10 creates a distinctive binding site, in which the RGD loop from domain 10 and the "synergy" region from domain 9 are on the same face of FN 7-10. Thus both binding sites are easily accessible to a single integrin molecule, which can explain synergistic properties of PHSRN in terms of the protein's structural features (Figure 2) (Leahy, 1996).

These cell binding sites can be reproduced as biologically active short peptides, and when presented to cells as a peptide, a cell-binding site of fibronectin can function in several different ways. It can mimic the intact protein as a substrate for integrin; for example, a peptide could be covalently attached to a synthetic matrix and bound by a cell-surface integrin. The peptide analogue can also serve as a competitive inhibitor and thereby block adhesion and migration. Finally, binding of fibronectin peptides can augment integrin signaling and induce expression of collagenase or activated cell-to-cell adhesiveness in particular cell types (Figure 3) (Miyamoto, 1995;Yamada, 2000). This can be important in wound healing. 
When the PHSRN was mixed with an RGD peptide, it did not show synergistic activity and it suggested that the spatial array between RGD and PHSRN in fibronectin could be necessary for synergistic activity (Aota, 1994). Hojo first prepared the active synthetic peptide containing both binding sites RGD and PHSRN and these fragments were linked by an amino acid/ poly(ethylene glycol) derivative (aaPEG). The PHSRNaaPEG-RGD hybrid strongly promoted cell spreading compared with aaPEG-RGD, which suggested a PHSRN synergistic effect for PHSRN in the hybrid peptide (Hojo, 2001).

Livant and coworkers used the naturally serum-free basement membranes and associated extracellular matrices of sea urchin embryos (SU-ECM) as in vitro invasion substrates to determine PHSRN sequence stimulating SU-ECM invasion by keratinocytes and fibroblasts (Livant, 2000a). They also found the wound healing effect of PHSRN peptide in healing-impaired and obese diabetic mice by stimulating re-epithelialization and contraction of dermal wounds. The arginine of this sequence appears to be crucial for its invasion-inducing activity because substitution of the arginine with an amino acid having a neural or negatively-charged side chain resulted in complete or near-complete loss in activity (Livant, 2000b). However, when arginine was replaced by cysteine, the peptide turned out to be a potent competitive inhibitor of PHSRN (Livant 2000b). The pentapeptide PHSCN could block both PHSRN and serum-induced invasion. Acetylated, amidated PHSCN (Ac-PHSCN-NH ) was 30-fold more potent. The PHSRN sequence induced invasion through $\alpha_{5} \beta_{1}$ integrin by interacting with the third $\mathrm{NH}_{2}$ terminal domain of the $\alpha_{5}$ chain, which formed a pocket that may contain a divalent cation (Aota, 1994). In peptide sequence $\mathrm{PHSCN}$, the large, electron-rich sulfhydryl group may allow the 
peptide to interact tightly in the binding pocket without inducing basement membrane invasion. Thus, Ac-PHSCN- $\mathrm{NH}_{2}$ may be a potent antitumorigenic and antimetastatic agent for postsurgical use prior to extensive metastasis (Livant, 2000a).

For a better understanding of the role of the unusual thio-containing cysteine residues, and to verify whether a divalent cation presents in the fibronectin and integrin binding pocket, we proposed that the cysteine in peptide PHSCN can be substituted by a metal chelating group. Among the metal chelating possibilities, we chose the hydroxamic acid function to incorporate within our synthetic peptide, since hydroxamic acid has significant metal binding ability towards a variety of transition metal ions. Preparing hydroxamate variants of PHSXN peptide was chosen as an important synthesis goal in our study. 
Figure 1 A model for FN9-10 binding to $\alpha 5 \beta 1$ integrin.

(Adapted from Redick, 2000)

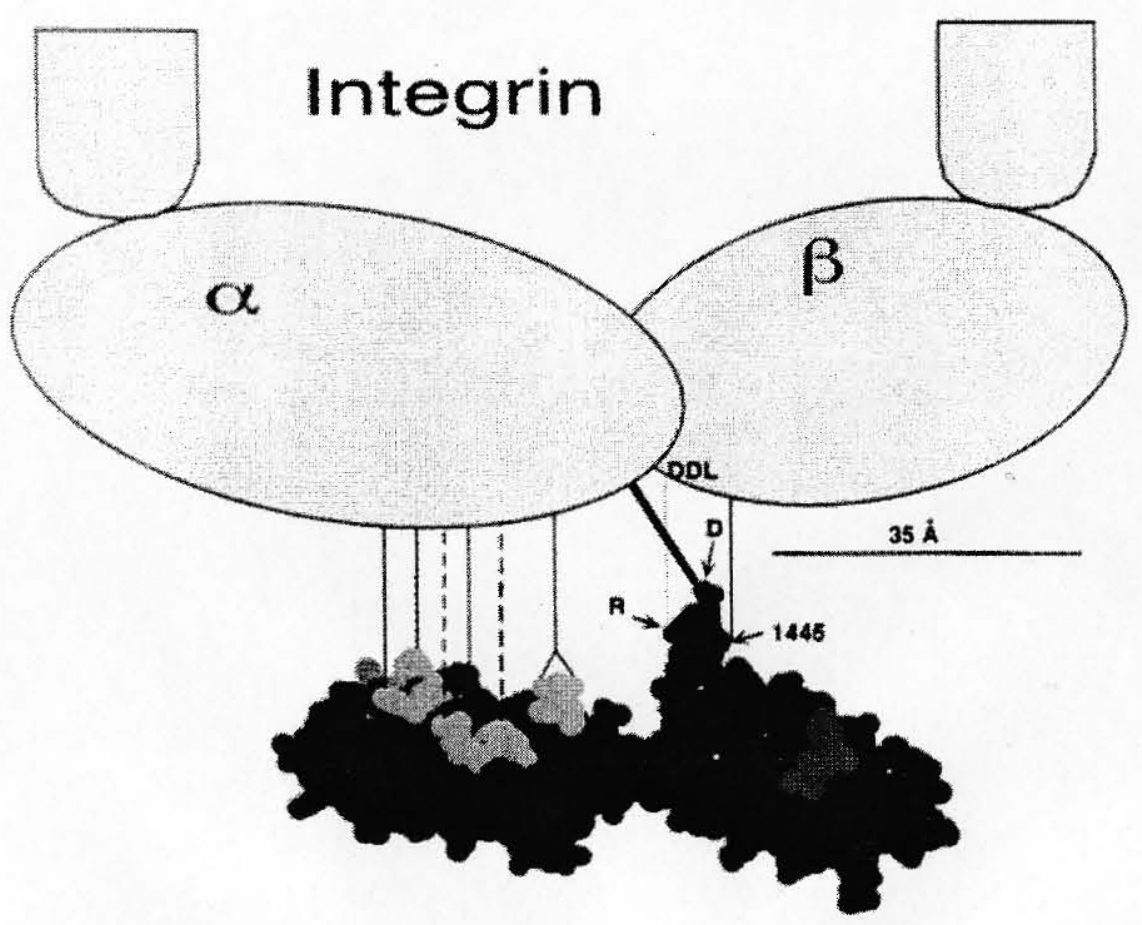

Figure 2 Three-dimensional structure of FN9-10 (Adapted from Leahy, 1996)

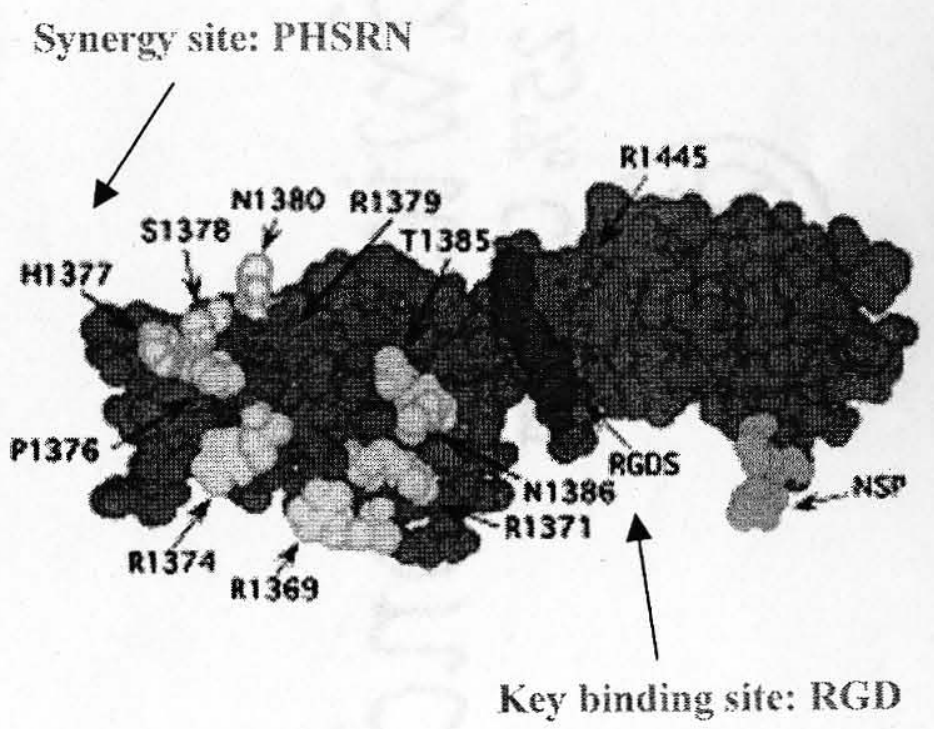


Figure 3 Synthetic fibronectin peptides with different functions (adapted from:

$$
\text { Yamada, 2000) }
$$

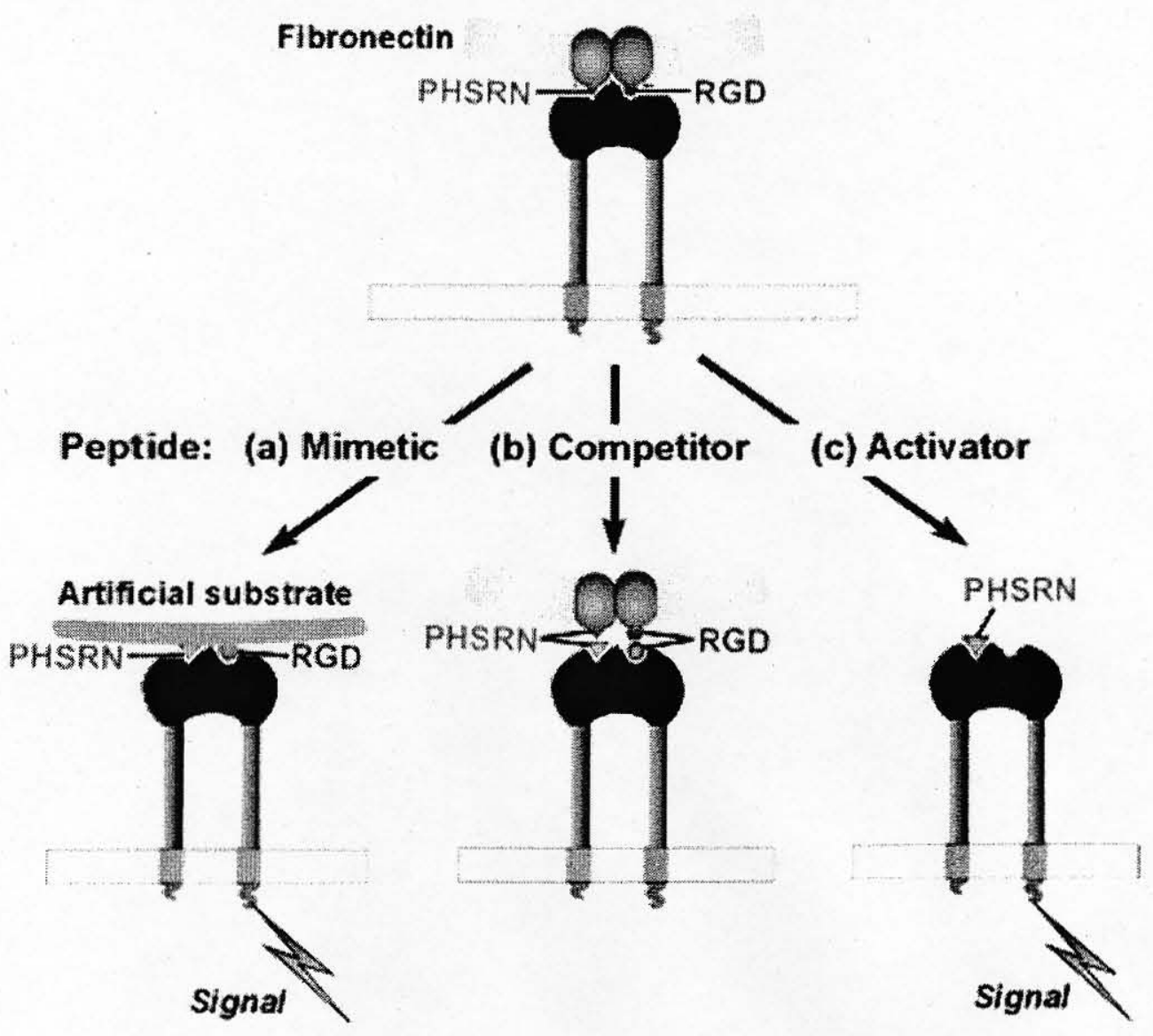




\section{Preparation of Hydroxamic Acid}

The organic synthesis of hydroxamic acid group has been extensively explored in past twenty years. In general the hydroxamic acid has been synthesized by coupling hydroxylamine or various $\mathrm{N}$ - or O-alkylated derivatives with activated carboxylic acids, carboxylic anhydrides, acyl chlorides or esters. Water soluble coupling reagents such as EDC (1-(3-Dimethylaminopropyl)-3-ethyl- carbodiimide hydrochloride) and DIC (diisopropylcarbodiimide) are frequently used. DCC is converted to DCU and can be easily removed by filtration. BOP is often used for better coupling and good chromatographic separation of products from impurities.

A conversion of the aminomalonic acid methyl ester into the corresponding hydroxamic acid was achieved by directly aminolysis of the methyl ester with hydroxylamine, or was effected via hydrolysis of the ester to the free malonic acid under the treatment with hydroxylamine hydrochloride, a tertiary amine and DCC (Krumme, 1998). Pirrung's group started from an amino acid ester and obtained an amino acid hydroxamate by refluxing the ester with O-benzylhydroxylamine trimethylaluminium reagent in toluene. The benzyl group was then removed by palladium catalyzed hydrogenation (Pirrung, 1995). $\mathrm{Pd} / \mathrm{C}$ catalyzed hydrogenation is a routine way to deprotect the O-benzyl group. However, in this procedure, a mixture of the desired hydroxamic acid and an amide (with $\mathrm{N}-\mathrm{O}$ bond cleavage) was invariably produced. Therefore, Mikam proposed the use of a milder catalyst $\mathrm{Pd} / \mathrm{BaSO}_{4}(5 \%)$ in order to obtain the clean hydroxamic acid product in good to excellent yield (Mikam, 1995). In another example, cyclo(Asu-Phe-Phe-D-Pro) was reacted with hydroxylamine, triethylamine and coupling reagent to generated cyclo(Asu(NHOH)-Phe-Phe-D-Pro). It is one of the first 
examples of a substituted cyclic peptide with a hydroxamic acid side chain (Furumai, 2001). The synthesis of unusual hydroxamic acids was reported by Krumme's group. A peptide containing an amide-bound oxalyl hydroxamic acid was prepared from a $\mathrm{N}$ terminal free peptide, which could be converted to its oxalic acid monomethyl ester under basic conditions. The oxalic acid ester was then cleaved with hydroxylamine in methanol to obtain the desired oxalyl hydroxamic acid derivatives (Krumme, 2002).

In recent years many research groups have started to prepare hydroxamic acids using solid phase reactions, which include introducing resin bound benzylhydroxylamine (Floyd, 1996) or binding the acetylating reagent on the resin before the coupling reaction (Chen and Spatola, 1997). Resin bound benzyl hydroxylamine was first introduced by Floyd and Whittaker and has been broadly used for C-terminal peptidic hydroxamic acid synthesis and for hydroxamate derivatives. Wang resin was converted to the Nhydroxyphthalimide derivative by using a Mitsunobu reaction (Figure 4). The Oactivated $p$-benzyloxybenzyl alcohol resin was treated with hydrazine in THF- ethanol to remove the phthalimido group, which resulted in the hydroxylamine resin. After the acylation, TFA was used to cleave the adduct from the resin to provide the free hydroxamic acid (Floyd, 1996). Following the same synthetic route, a resin with an $\mathrm{ONH}_{2}$ anchor was synthesized from SASRIN resin (super acid sensitive resin ${ }^{\mathrm{TM}}$ ) (Figure 5). After peptide elongation, the peptide could be cleanly cleaved from the resin under very mild condition (5\% TFA-DCM, $15 \mathrm{~min}$ ) to give the corresponding hydroxamic acid (Barlaam, 1999). 
Table 1 Preparation of hydroxamic acids by the acylation of hydroxylamine and derivatives

\begin{tabular}{|c|c|c|c|c|}
\hline $\begin{array}{l}\text { Hydroxylamine } \\
\text { or derivative }\end{array}$ & Acylating Reagent & Reaction Condition & Product & Ref \\
\hline $\mathrm{NH}_{2} \mathrm{OH} \cdot \mathrm{HCl}$ & DCC activated malonic acid & $\begin{array}{c}\mathrm{Et}_{3} \mathrm{~N} \text { in } \mathrm{DMF} \\
\text { at } 0-5^{\circ} \mathrm{C}\end{array}$ & Aaa-Ame(NHOBn)-Aaa'- $\mathrm{R}_{2}$ & $\begin{array}{c}\text { Krumme } \\
1998\end{array}$ \\
\hline $\mathrm{NH}_{2} \mathrm{OH} \cdot \mathrm{HCl}$ & Malonic acid ester & $\begin{array}{c}\mathrm{CH}_{3} \mathrm{ONa} \text { in anhydrous } \\
\mathrm{MeOH} \text { at } 5^{\circ} \mathrm{C}\end{array}$ & Aaa-Ame(NHOBn)-Aaa'- $\mathrm{R}_{2}$ & $\begin{array}{l}\text { Krumme } \\
1998\end{array}$ \\
\hline $\mathrm{NH}_{2} \mathrm{OH}$ & $\begin{array}{c}\text { BOP, HOBt activated } \\
\text { cyclo(Asu-Phe-Phe-D-Pro) }\end{array}$ & $\mathrm{DMF}, \mathrm{rt}$ & cyclo(Asu(NHOH)-Phe-Phe-D-Pro) & $\begin{array}{l}\text { Furumai } \\
2000\end{array}$ \\
\hline$i$-PrNHOH & $\begin{array}{l}\text { EDC activated triscarboxylic } \\
\text { acid }\end{array}$ & $\begin{array}{c}\text { THF }-\mathrm{H}_{2} \mathrm{O}(1: 1) \\
\text { pH 4.8, rt }\end{array}$ & trishydroxamic acids & $\begin{array}{c}\text { Karunaratne } \\
1992\end{array}$ \\
\hline $\mathrm{Me}_{2} \mathrm{AlCINHOR}^{\prime}$ & $\mathrm{RCO}_{2} \mathrm{Me}$ & benzene, reflux & RCONHOR' & $\begin{array}{l}\text { Pirrung } \\
1995\end{array}$ \\
\hline $\mathrm{NH}_{2} \mathrm{OH}$ & Oxalic acid ester & methanol & Oxal hydroxamic acid derivative & $\begin{array}{l}\text { Krumme } \\
2002\end{array}$ \\
\hline
\end{tabular}




\section{Continued Table 1}

(treated with


Figure 4 Preparation of aminoxymethyl-Wang resin via Whittaker's protocol

(Flyod, 1996)
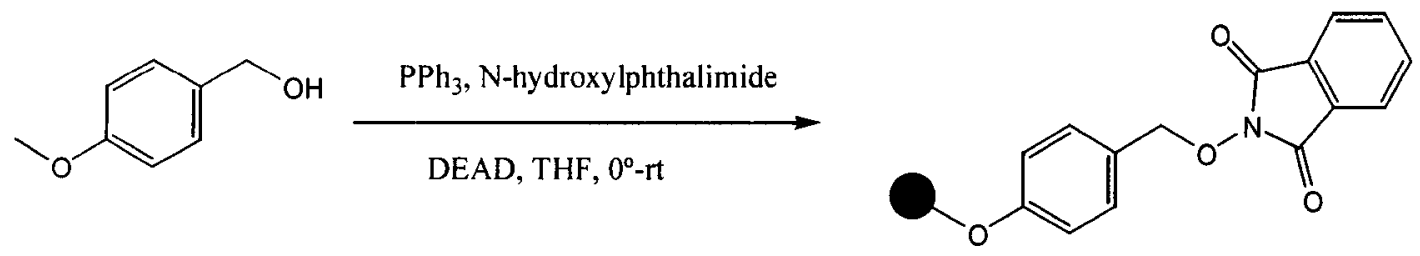

Hydrazine, THF-ethanol, $0^{\circ}-\mathrm{rt}$<smiles>COc1ccc(CON)cc1</smiles>

Figure 5 SASRIN resin with $\mathrm{ONH}_{2}$ anchor (Barlaam, 1999)

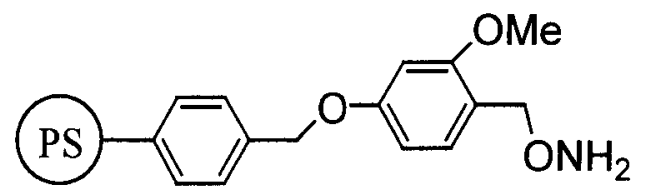

Hydroxamic acids could be prepared from some non-activated carbonyl functional groups. Whittaker's group reported a method for introducing a hydroxamic acid functionality via the palladium catalyzed carbonylation of aryl iodides and subsequent trapping of the acylpalladium (II) intermediate with a resin-bound hydroxylamine. Simultaneous deprotection and cleavage with TFA afforded the free hydroxamic acids (Grigg, 1999). The synthesis of an acyclic hydroxamic acid fragment can also commence with nitrone, which was treated with hydroxylamine hydrochloride and the product hydroxylamine was reacted with an excess of formic acid by the use of EDC to give an $\mathrm{N}$ - and O-formate moiety. Subsequent removal of the O-formate group afforded the hydroxamate in $71 \%$ yield (Yokokawa, 2000). 


\section{B Research Objectives}

PHSRN represents the peptide sequence with biological importance in cell adhesion, cell morphology, cell migration and wound healing, and its competitive inhibitor, PHSCN, has significant antimetastatic and antitumorigenic activities (Livant, 2000a). We selected twelve analogues of the PHSXX' sequence series as synthetic targets, some with unnatural amino acids, in order to explore their structure activity relationships. All analogues were prepared with their N-terminal acetylated, and Cterminal amidated as Ac-PHSXX'- $\mathrm{NH}_{2}$. The side chains were modified at only the $\mathrm{X}$ and X' positions, but included aromatic, acidic and hydroxyl replacements for arginine/cysteine and for asparagines.

As mentioned earlier, we were also interested in the role of the unusual thiocontaining cysteine residues. The SH group could be a potential metal chelator or could play another role. In 1994, Aota and coworkers proposed that the protein $(\mathrm{pFn})$ and ligand (integrin) binding pocket may contain a divalent cation (Aota, 1994). If it were the case, PHSCN could coordinate a divalent cation, block the overall fibronectin protein binding to the receptor, and inhibit cell invasion. Therefore we decided to replace the cysteine with a chelating group to reveal whether metal binding might represent an important consideration for the design of second-generation compounds.

Among the metal chelating possibilities, we chose the hydroxamic acid function to incorporate within our synthetic peptide, since it has significant metal binding ability towards a variety of transition metal ions. It is among the most widely observed chelating agents in natural ionophores and it has well-known pharmaceutical applications. Hydroxamic acids have been shown to have a role in MMP (matrix metalloproteinase) 
inhibition, since they can serve as bidentate ligands to block MMP's at their central $\mathrm{Zn}(\mathrm{II})$ active site. PHSCN was reported to inhibit the expression of specific metalloproteinases functioning in cell migration through the extracellular matrix (Livant, 2000a). Therefore we aimed at preparing hydroxamate variants of PHSCN sequence and evaluating the angiogenesis activity of these hydroxamate peptides in order to achieve a better understanding of fibronectin - integrin interaction mechanism.

\section{Results and Discussion}

\section{Synthesis of Amino Hydroxamate Building Blocks}

In order to produce hydroxamate analogs by solid phase methods, it would be convenient to have appropriately protected building blocks. Accordingly we decided to prepare both aspartic acid and glutamic acid derived amino hydroxamates, BocAsp(NHOBn)-OH and Boc-Glu(NHOBn)-OH (Figure 6). These orthogonally protected building blocks could be used in Boc chemistry solid phase peptide synthesis. The side chain O-benzyl protecting group could be resistant to $50 \%$ TFA Boc group deprotection and be removed by HF when the peptide is cleaved from the resin.

Figure 6 Hydroxamate aspartic acid and glutamic acid building blocks
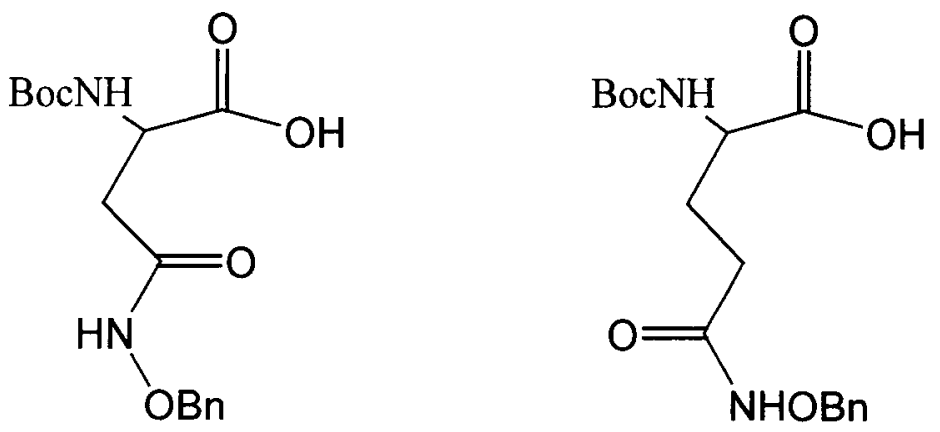
Boc-Asp-OFm was the key intermediate in the synthesis of Boc-Asp(NHOBn)$\mathrm{OH}$, following the method previously described (Spatola, 1996) (Figure 7). Boc-Asp-OH was converted to its anhydride by using the coupling reagent, DCC. Next the anhydride was esterified with 9-fluorenylmethanol and this provided a mixture of $\alpha$ - and $\beta$ fluorenylmethyl esters. The desired product, $\alpha$-fluorenylmethyl ester, was separated by recrystallization from EtOAc/ hexane. O-benzylhydroxylamine was then coupled to the $\beta$ - carbonyl group to afford Boc-Asp(NHOBn)-OFm. After base deprotection of the Fm group, the aspartic acid hydroxamate building block Boc-Asp(NHOBn)-OH was obtained in $97 \%$ purity and $65 \%$ yield (from Boc-Asp-OFm). Similarly Boc-Glu(NHOBn)-OH was prepared from Boc-Glu-OFm in $94 \%$ purity and $71 \%$ yield.

Figure 7 Synthesis of Boc-Asp-OFm from Boc-Asp-OH (from Boc-Asp-OH)<smiles>CC(C)(C)N[C@@H](CC(=O)O)C(=O)O</smiles><smiles>O=C1CC(NC(=O)c2ccccc2)C(=O)O1</smiles>

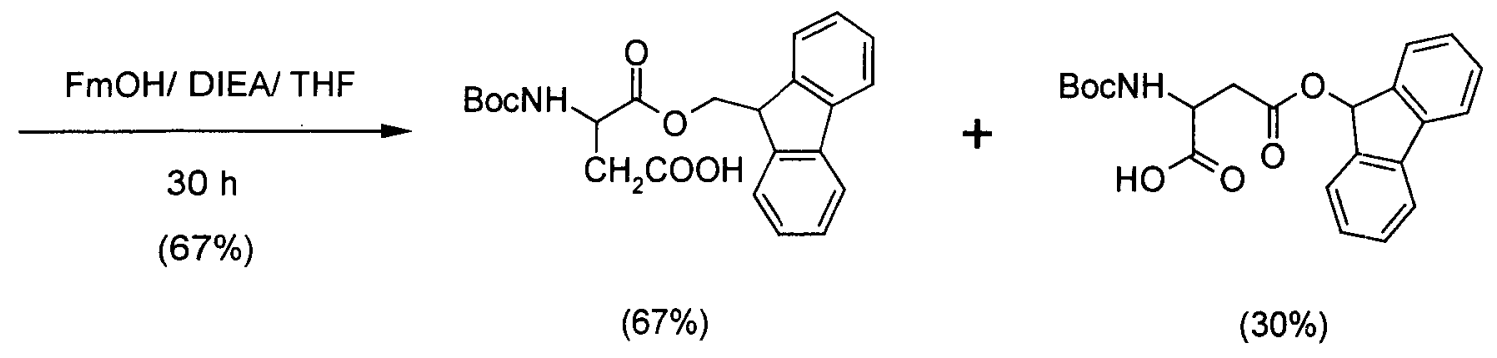


Figure 8 Synthesis of Boc-Glu-OFm from Boc-Glu(OBn)-OH
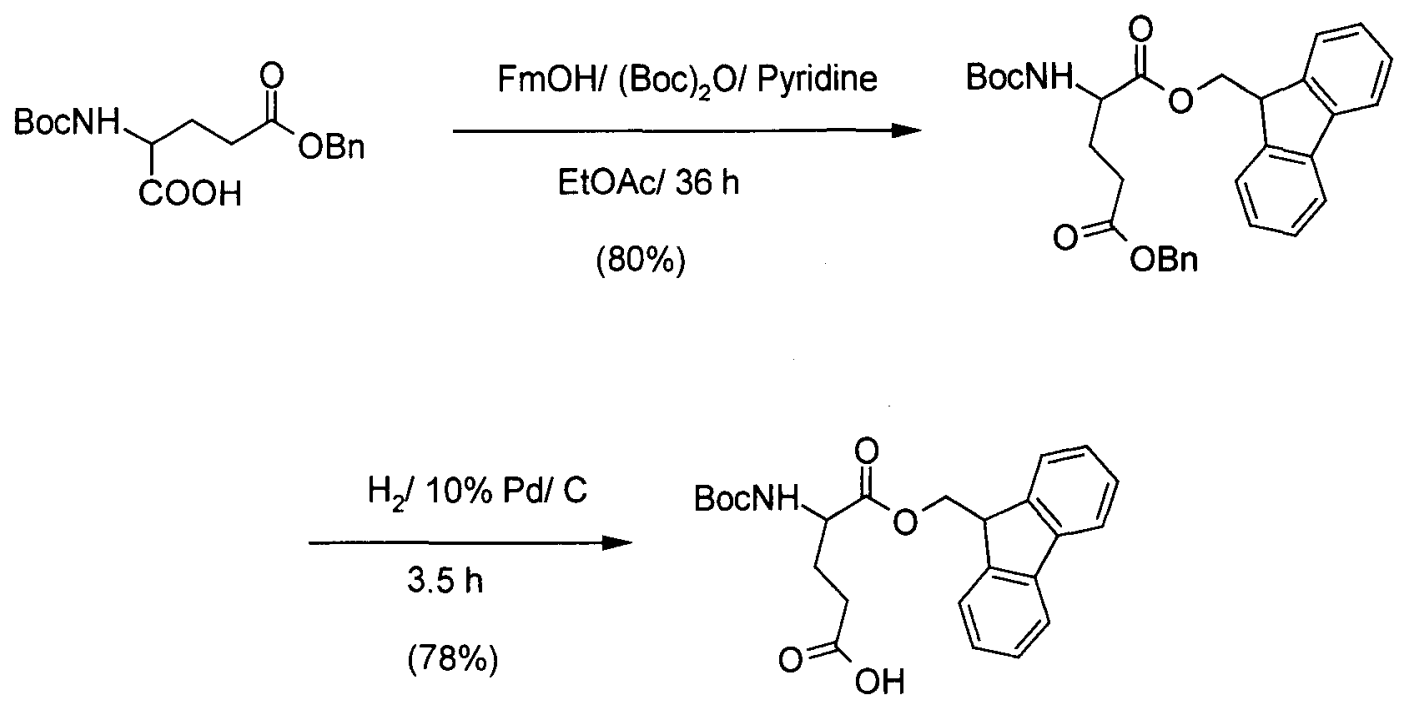

In order to synthesize Boc-Glu-OFm, we started from the commercially available Boc-Glu(OBn)-OH (Figure 8 ). The $\alpha$-carbonyl group was first protected by fluorenyl methyl group and the $\gamma-\mathrm{OBn}$ group was removed by partial hydrogenation $(3.5 \mathrm{~h})$, which provided Boc-Glu-OFm (Romanovskis and Spatola, 1998). The Boc-Glu-OFm was then treated by the same method as Boc-Asp-OFm to afford Boc-Glu(NHOBn)-OH in $94 \%$ purity and 71\% yield (from Boc-Glu-OFm). For both Boc-Asp(NHOBn)-OFm and BocGlu(NHOBn)-OFm, the fluroenyl methyl group was removed by $5 \% \mathrm{w} / \mathrm{v}$ piperazine in THF to provide the Boc protected $\mathrm{N}^{\alpha}$-aspartyl hydroxamate and $\mathrm{N}^{\alpha}$-glutamyl hydroxamate, which each has the $\alpha$-carboxylic group available for further modification (Figure 9). 
Figure 9 Synthesis of Boc-Asp(NHOBn)-OH and Boc-Glu(NHOBn)-OH<smiles>CC(C)(C)OC(=O)NC(CC(=O)O)C(=O)OCC1c2ccccc2-c2ccccc21</smiles><smiles>Nc1ccc(Br)cc1</smiles><smiles>CC(C)(C)OC(=O)NC(CC(=O)NCc1ccccc1)C(=O)OCC1c2ccccc2-c2ccccc21</smiles>

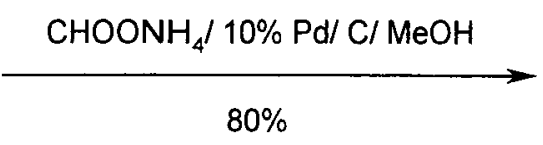<smiles>Cc1ccccc1</smiles>

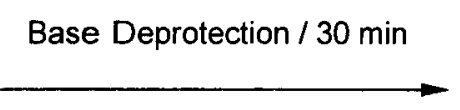

$(65-70 \%)$<smiles>CC(C)(C)OC(=O)N[C@@H](CC(=O)NCc1ccccc1)C(=O)O</smiles>

\section{Attempted Synthesis of Peptides Using a Protected Hydroxamic Acid-}

\section{Containing Amino Acid as a Preformed Building Block}

The new hydroxamate building blocks were next combined with Asn-MBHA resin under different reaction conditions using 1) BOP /HOBt /DIEA, 2) HBTU/DIEA or 3) the strong coupling reagent TFFH (Carpino, 1995) as coupling reagents (Figure 10). However none of these reactions was successful, as monitored by the ninhydrin reaction. By analysis of the reaction mixture after each coupling reaction, we isolated $\mathrm{N}$-OBn aspartimide as the glutaimide. The stable heterocycles were formed due to the side chain amide nitrogen, which could attack the activated carbonyl group and give the unwanted cyclized imide product. Once the stable five-membered aspartimide or six-membered 
glutaimide ring on the activated carboxylic acid formed (Figure 10), the nucleophilic amine on the resin could no longer be coupled to the hydroxamate amino acid building block. Therefore, Boc-Asp(NHOBn)-OH and Boc-Glu(NHOBn)-OH were shown to be actively self-cyclized building blocks and were not appropriate for regular coupling reactions.

Figure 10 Attempted coupling hydroxamate building blocks to peptide chain

\begin{tabular}{|c|c|c|}
\hline \multirow{2}{*}{ Boc-Asp(NHOBn)-OH } & $X-M B H A$ resin & \\
\hline & $\mathrm{X}$ : Leu, Phe or Asn & Boc-Asp(NHOBn)-X-MBHA resin \\
\hline or & $\longrightarrow x \longrightarrow$ & or \\
\hline $\mathrm{Boc}-\mathrm{Glu}(\mathrm{NHOBn})-\mathrm{OH}$ & $\begin{array}{l}\text { BOP/ DIEA DMF } \\
\text { HBTU/ DIEA/ DMF } \\
\text { TFFH/ DMF }\end{array}$ & Boc-Glu(NHOBn)-X-MBHA resin \\
\hline
\end{tabular}

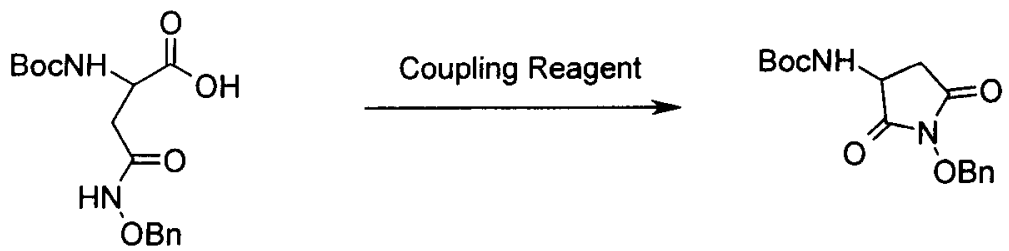<smiles>CC(C)(C)NC1CCC(=O)N(OCc2ccccc2)C1=O</smiles>

\section{Solid Phase Synthesis of Side Chain Hydroxamic Acid Peptide}

Hydroxamic acid peptides were previously prepared on a solid support according to an effective method set up by Chen (Chen and Spatola, 1997). In this procedure a peptide containing an appropriately functionalized amino acid with a protected carboxylic 
residue was assembled on the resin, prior to the side chain carboxylic group undergoing an $\mathrm{N}$ to $\mathrm{C}$ amidation.

As shown in Figure 11, a residue bearing a protected carboxylic residue was introduced using orthogonally protected Asp/Glu derivatives. The side chain carboxylate group was modified by solid phase $\mathrm{N}$ to $\mathrm{C}$ amidation using an O-benzylhydroxylamine. The O-benzyl protection group can be removed concomitantly before or after the peptide resin cleavage to afford the functionalized hydroxamate side chain.

For the synthesis of Ac-PHSX(NHOH)X'-NH $\mathrm{NH}_{2}$ analogs, Fmoc-Glu( $\left.{ }^{t} \mathrm{Bu}\right)-\mathrm{OH}$ or Fmoc- $\mathrm{Asp}\left(\mathrm{O}^{t} \mathrm{Bu}\right)-\mathrm{OH}$ was incorporated onto $\mathrm{X}^{\prime}-\mathrm{MBHA}$ resin by coupling with protected O-benzylhydroxylamine to afford Fmoc- $\mathrm{X}\left(\mathrm{O}^{t} \mathrm{Bu}\right)-\mathrm{X}^{\prime}-\mathrm{MBHA}$ resin. Subsequent TFA treatments deprotected the $\mathrm{O}^{\mathrm{t}} \mathrm{Bu}$ protecting group and the unprotected carbonyl group was available for further modification. $\mathrm{BnONH}_{2} \cdot \mathrm{HCl}$ was condensed with $\mathrm{BOP}$ and DIEA, which provided Fmoc-X(NHOBn)-X'-MBHA resin and the remaining amino acids were coupled to the resin via routine Fmoc solid phase chemistry. After HF cleavage, the crude peptides were obtained. When tested with the $\mathrm{FeCl}_{3}$ test, the compounds gave the requisite pink (positive) hydroxamic acid test. Further analysis included proton NMR spectroscopy, which gave the characteristic pair of signals near 10 ppm indicating an NHOH moiety, and MALDI-TOF MS which confirmed the expected masses.

By following the method described above, a series of hydroxamic acid peptides could be synthesized. Table 2 summarizes the results from HPLC assay of the crude peptide and final reaction yields after purification. 
Figure 11 Preparation of Ac-PHSE(NHOH)N-NH

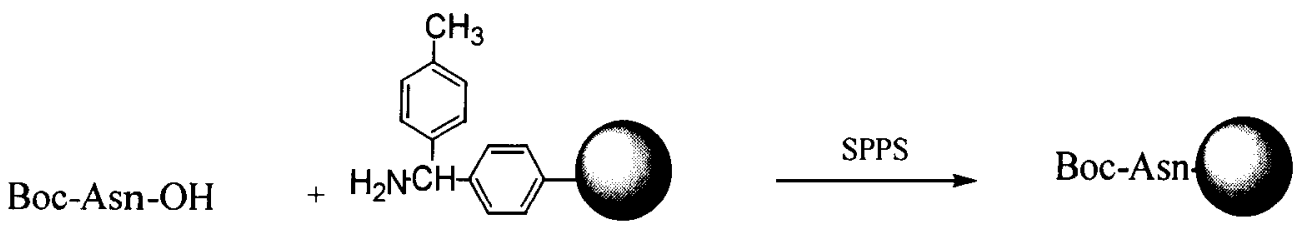

1) $\mathrm{TFA} / \mathrm{DCM} /$ Anisole (50/45/5)

2) Fmoc-Glu( $\left.\mathrm{O}^{t} \mathrm{Bu}\right)-\mathrm{OH}, \mathrm{BOP}, \mathrm{HOB}$, DIEA in DMF

Fmoc-Glu( $\left.\mathrm{O}^{\mathrm{t}} \mathrm{Bu}\right)-\mathrm{Asn}$

TFA/ DCM/ Anisole (70/25/5)

3. $30 \mathrm{~min}$

Fmoc-Glu-Asn

$\mathrm{NH}_{2} \mathrm{OBn}, \mathrm{BOP}, \mathrm{HOBt}$, DIEA in DMF

Fmoc-Glu(NHOBn)-Asn

Fmoc cycle three times

Fmoc-Pro-His(Trt)-Ser(tBu)-Glu(NHOBn)-Asn-

$20 \%$ Piperidine in DMF

Acetic Anhydride, DIEA in DCM

Ac-Pro-His(Trt)-Ser(tBu)-Glu(NHOBn)-Asn-

$\mathrm{HF}$, anisole

Ac-Pro-His-Ser-Glu(NHOH)-Asn- $\mathrm{NH}_{2}$ 
Table 2 Solid phase synthesis of side chain peptide hydroxamic acids by the following the hydroxamate peptide synthesis method in Figure 11

\begin{tabular}{cccccc}
\hline No & Peptide hydroxamic acid & $\begin{array}{c}\text { Peptide Content in } \\
\text { Crude peptide }(\%)^{\mathrm{a}}\end{array}$ & Yield (\%) $^{\mathrm{b}}$ & MW calcd & MW found (M+1) \\
\hline 1 & Ac-Pro-His-Ser-Glu(NHOH)-Leu-NH & 86 & 78 & 637.7 & 638.7 \\
2 & Ac-Pro-His-Ser-Glu(NHOH)-Asn-NH & 83 & 80 & 638.6 & 639.9 \\
3 & Ac-Pro-His-Ser-Asp(NHOH)-Asn-NH & 54 & 41 & 624.6 & 625.8 \\
\hline
\end{tabular}

${ }^{a}$ Determined by RP-HPLC at $\lambda=220 \mathrm{~nm}$. ${ }^{b}$ Calculated after RF-HPLC purification according to the initial substitution level $(1.25 \mathrm{meq} / \mathrm{g})$ on the pMBHA resin. ${ }^{\mathrm{c}}$ Obtained by MALDI-TOF MS 
As shown in Table 2, the peptide Ac-Pro-His-Ser-Asp(NHOH)-Asn- $\mathrm{NH}_{2}$ was synthesized with much lower reaction yield than the Glu version peptide Ac-Pro-His-SerGlu(NHOH)-Asn-NH2. An MALDI-MS result suggested there was a major impurity in the former, with a mass of 592.8 in the crude peptide. This mass was the result of formation a major side product. Presumably, the presence of this impurity only in the aspartyl case may be related to the greater stablity of a five-membered ring (Figure 12).

Figure 12 Side product in the preparation of Ac-Pro-His-Ser-Asp(NHOH)-Asn- $\mathrm{NH}_{2}$

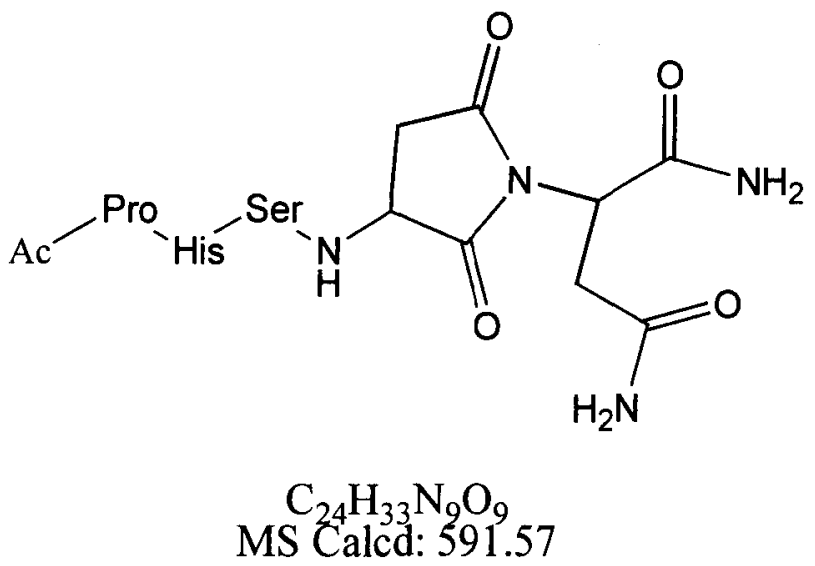

\section{Aspartimide Inhibition Study in the Synthesis of Peptide Ac-}

\section{PHSD(NHOH)N-NH}

Aspartimide formation in classic Boc or Fmoc-solid phase synthesis of sensitive sequences is a serious side reaction that is difficult to both anticipate and control (Bodanszky, M. and Martinez, J., 1978). Aspartimide formation could be both acid and base catalyzed (Figure 13,14 and 15). The ring closure can be spontaneous, because of the thermodynamic stability of the five-membered aspartimide ring; the latter is nonetheless reactive and opens up readily under attack by nucleophiles. Strongly acidic conditions were required for the acidolytic cleavage of the side chain protecting group 
and the loss of benzyl alcohol was accompanied by the formation of succinimide derivatives. Among the acids that catalyze the ring closure reaction, $\mathrm{HBr}$ in acetic acid and liquid HF were found to be contributory for this problem (Bodanszky, M. and Martinez, J., 1978).

Figure 13 Mechanism of aspartimide formation in aspartic acid containing peptide<smiles>[R]C(=O)CC(N)C(=O)NC([R])C(=O)C(C)(C)C</smiles><smiles>[R6][R6](=O)(O)O</smiles><smiles>[R]C(C(C)=O)N1C(=O)CC(N)C1=O</smiles>

Figure 14 Acid catalyzed aspartimide formation<smiles>CCNC(CC(=O)NOCc1ccccc1)C(=O)NC(CC(N)=O)CC(=O)I</smiles><smiles>CCNC(CC(=O)NOCc1ccccc1)C(=O)NC(CC(N)=O)CC(=O)I</smiles><smiles>CC(=O)CC(CC(N)=O)N1C(=O)CC(NC(C)C)C1=O</smiles>

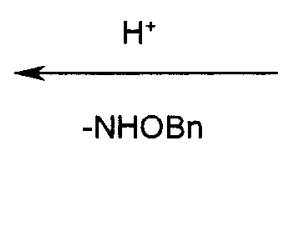

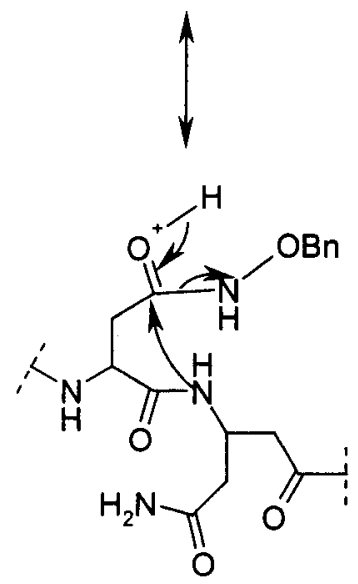


Base-induced aspartimide (cyclic imide) formation in Fmoc chemistry is shown in Figure 15. The extent of the aspartimide side-reaction is dependant upon the base employed for removal of the Fmoc group, and on the C-terminal residue of the aspartyl bond (especially prone are Gly, Ser, Thr, Asn and Gln). The ring closure reaction starts from the deprotonation of an $\mathrm{NH}$ group of a neighboring residue, followed by nucleophilic attack of the $\beta$-carboxyl group to form a stable five-membered ring (Figure $15)$.

Figure 15 Base catalyzed aspartimide formation<smiles>CC(C)CC(CC(N)=O)NC(=O)C(CC(=O)O)NC(C)C</smiles>

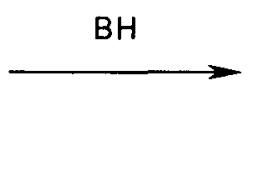<smiles>CCCCC(=O)N(C(=O)CC(C)C)C(CC(N)=O)CC(=O)C(C)C</smiles><smiles>CC(C)NC1CC(=O)N(C(CC(N)=O)CC(=O)C(C)(C)C)C1O</smiles>

Although there are no literature reports concerning the aspartimide formation during O-benzylhydroxamate aspartyl peptide synthesis, we believe that the aspartimide 
formation observed in peptide $\mathbf{3}$ followed a similar mechanism as succinimide formation from $\beta$-benzyl aspartyl residues (Figure 16).

Following coupling of the second amino acid in peptides $\mathbf{3}$, synthesis was continued by using Fmoc chemistry, and after peptide chain elongation, anhydrous HF was used to cleave the peptide from the resin and remove the remaining protecting groups. Thus, both acid and basic catalyzed aspartimide formation needed be avoided in an optimized method. However, little work could be done to inhibit the acid catalysis of aspartimide formation in our scheme, since HF cleavage was the primary choice in cleaving the peptide from MBHA resin and provided the C-terminal amidated peptide. Thus we initiated a study involving inhibition of base catalyzed aspartimide formation.

In the process of one $\mathrm{N}$ to $\mathrm{C}$ coupling, the $\beta$-carboxyl group of $\mathrm{O}$ benzylhydroxamate aspartic acid could be competitively attacked by either nucleophile NR group including amide nitrogen of the neighboring residue or the incoming Obenzylhydroxylamine (Figure 16, path 1). The hydroxylamine coupling provided the desired product, while amide $\mathrm{N}$ attack formed a stable five-membered aspartimide side product. In the meantime, the side product could also be formed from resin bound peptide. The deprotonated amide nitrogen would attack the aspartyl $\beta$-carbonyl group and NHOBn would be the leaving group in this cyclization reaction (Figure 16, path 2). 
Figure 16 Aspartimide formation in N-C coupling (path 1) and in peptide chain elongation (path 2)

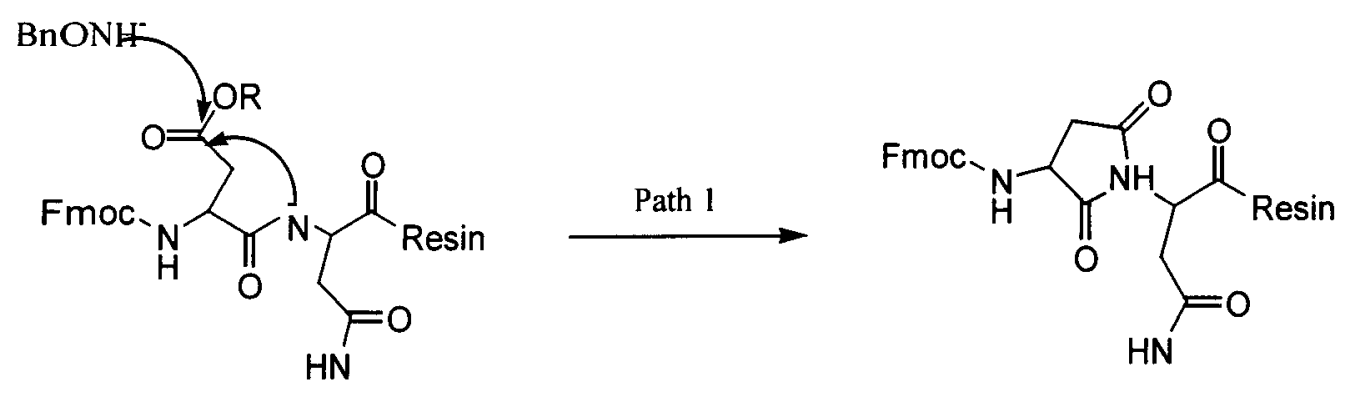

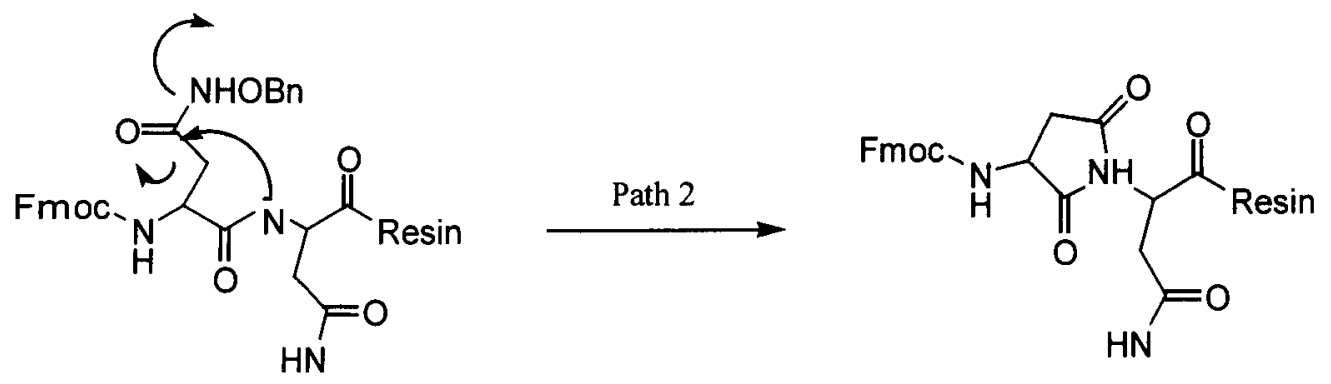

Offer and his coworkers reported that the use of N-(2-acetoxyl-4-methoxybenzyl) (AcHmb) aspartyl amide-bond protection is able to suppress the formation of aspartimide in both the initial chain assembly and during the activation and modification of the aspartyl $\beta$-carboxyl group (Offer, 1996) (Figure 17). In that case, the amide nitrogen proton of the aspartyl bond was replaced and the self-cyclization could not proceed. 
Figure 17 Backbone protecting group Hmb<smiles>[X]C(=O)CC(NC)C(=O)N(Cc1ccc(OC)cc1OC(C)=O)C([R])C(C)=O</smiles>

-Asp-(Hmb)AA-

Another application involving peptide synthesis on a base-labile functionalized resin was carried out in Rabanal's group and great success was achieved by using the bifunctional linker $N$-[9-hydroxylmethyl]-2-fluorenyl] succinamic acid (HMFS) handle on PEGA-resin (Figure 18). They synthesized the peptide containing an -Asp-Alasequence on a HMFS-PEGA-resin using Boc/Bn chemistry and cleaved the peptide from resin with a mild base, morpholine (Rabanal, 2000). This strategy effectively eliminated the aspartimide formation by avoiding strong acid (HF cleavage) or strong base (piperidine deprotection).

In another approach a new protecting group for aspartic acid was synthesized and applied in both Fmoc and Boc solid phase peptide synthesis with minimal aspartimide formation. The protecting group, $\beta-3-$ methylpent-3-yl (Mpe) ester, has good flexibility and large steric hindrance and can interfere with the attack of the amide bond nitrogen on the $\beta$-carbonyl group and /or the abstraction of the $\mathrm{NH}$ proton at the amide bond (Karlström, 1996; Karlström, 1995). 
Figure 18 New strategies to inhibit aspartimide formation using HMFS linker or Mpe ester

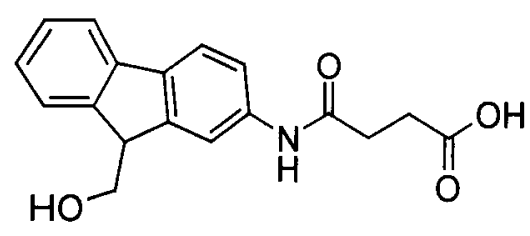

HMFS handle<smiles>CCC(C)(CC)OC(=O)CC(NP(=O)(O)c1ccccc1)C(=O)O</smiles>

$-A s p(O M p e)-O H$

Among these reported methods to inhibit base catalyzed aspartimide formation, most of them employ novel aspartic acid side chain protecting groups or backbone protecting groups (Karlström, 1996; Karlström, 1995; Rabanal, 2000) and none of these could provide an efficient solution for our problem. Therefore we combined several strategies in optimization of the chemistry of Figure 11 to improve the overall yield of our hydroxamated aspartic acid peptide. First we introduced a neighboring residue with a bulky side chain; that is, we used Boc-Asn(Xan)-OH to replace the unprotected Boc-Asn$\mathrm{OH}$ (Figure 19). Usually asparagine can be used in either Boc or Fmoc chemistry without a side chain protecting group. In our study the bulky 9-xanthenyl (Xan) group was introduced as a side chain protecting group to increase the steric hindrance toward asparagines $\mathrm{N}^{\alpha}$ deprotonation and consequently impede the intramolecular ring closure process.

Base induced aspartimide formation could also be inhibited by the use of piperazine in $\mathrm{N}^{\mathrm{a}}$-Fmoc deprotection according to a report from Wade (Wade, 2000). The 
effect of extended treatment of piperazine as reagent on two sensitive peptide sequences was examined and piperazine caused less side reactions comparing to other bases, including piperidine, 1-hydroxypiperidine, tetrabutylammonium fluoride, or 1,8diazabicyclo[5.4.0]undec-7-ene (Wade, 2000). Therefore, $6 \% \mathrm{w} / \mathrm{v}$ piperazine in DMF was used to replace $25 \%$ piperidine in DMF for Fmoc deprotection in our later hydroxamate peptide syntheses.

As mentioned before, in the process of N-C coupling our activated carbonyl group could be competitively attacked by nucleophiles, either NHOBn or the neighboring backbone NH. However, the NHOBn was protonated after TFA treatment of the peptide and the coupling step could be slowed down. NHOBn would lose its edge in the competition and this would result in aspartimide formation. It has been reported that an extra neutralizing step would eliminate the effect of residual acid (TFA) in aspartimide formation (Chen and Spatola, 1997).

Figure 19 Boc-Asn(Xan)-OH<smiles>CC(C)(C)OC(=O)N(CC(=O)OC1c2ccccc2Oc2ccccc21)C(=O)O</smiles> 
Overall four modifications were made to the optimized method (Figure 20) compared to the original method (Figure 11). Boc-Asn-OH was replaced by BocAsn(Xan)-OH, 6\% w/v piperazine was used in Fmoc deprotection, and the resin was neutralized by $10 \%$ DIEA before N-C coupling. Most importantly the side chain modification was introduced after the peptide chain was elongated, in order to minimize the exposure of the NHOBn group to piperazine and eliminate the aspartimide formation observed in Figure 16 path 2 . These changes lead to obvious improvement in the synthesis of Ac-Pro-His-Ser-Asp(NHOH)-Asn- $\mathrm{NH}_{2}$, since the yield was increased from $41 \%$ to $68 \%$ and the formation of succimide was effectively inhibited.

Figure 20 Modified methodology to prepare Ac-PHSD(NHOH)N-NH

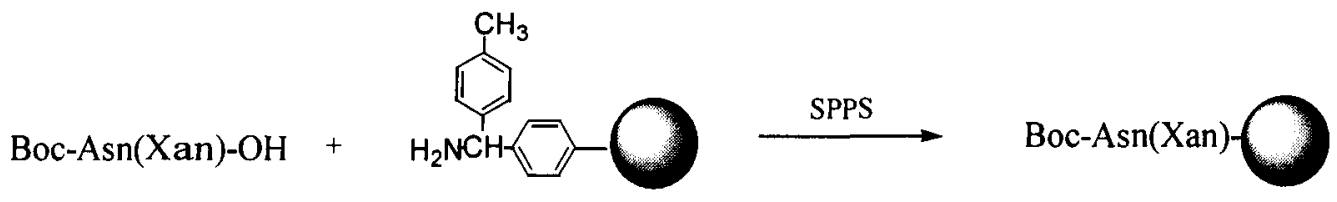

1) TFA/DCM/ Anisole (50/45/5)

2) Fmoc-Asp $\left(\mathrm{O}^{t} \mathrm{Bu}\right)-\mathrm{OH}, \mathrm{BOP}, \mathrm{HOBt}, \mathrm{DIEA}$ in DMF

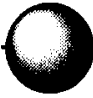

1) $6 \% \mathrm{w} / \mathrm{v}$ piperazine in DMF

Fmoc cycle four times

Fmoc-Pro-His(Trt)-Ser(tBu)-Asp( $\left.\mathrm{O}^{t} \mathrm{Bu}\right)-\mathrm{Asn}(\mathrm{Xan})$

1) $6 \% \mathrm{w} / \mathrm{v}$ piperazine in $\mathrm{DMF}$

2) Acetic Anhydride, DIEA in DCM Ac-Pro-His(Trt)-Ser(tBu)-Asp( $\left.{ }^{t} B u\right)-A s n(X a n)$

1) TFA/DCM/Anisole (70/25/5), $3 \times 30 \mathrm{~min}$

2) $10 \%$ DIEA in DMF

3) $\mathrm{NH}_{2} \mathrm{OBn}, \mathrm{BOP}, \mathrm{HOBt}$, DIEA in DMF

Ac-Pro-His-Ser-Asp(NHOBn)-Asn (Xan)

$\mathrm{HF}$, anisole

Ac-Pro-His-Ser-Asp(NHOH)-Asn- $\mathrm{NH}_{2}$ 


\section{Parallel Synthesis of Ac-PHSXX'-NH $\mathrm{NH}_{2}$ Peptides}

Analogues of parent peptides PHSRN and PHSCN were prepared to explore the role of several of the amino acids in peptide's cell invasion inducing activity. As mentioned before, hydroxamate derivatives of PHSXX' peptide were prepared because of the high metal binding ability of hydroxamic acids and the activity of hydroxamate peptides would indicate if the metal binding is involved in the anti-invasion-inducing activity. Peptide PHSDN, the precursor of PHSD(NHOH)N, was also included in these analogues. In the meantime, cysteine was replaced by a similar sized amino acid, serine, which has a hydroxyl side chain, and unlike the thiol group, does not have metal binding ability.

The importance of the C-terminal asparagine was examined by substituting it with Phe and Tyr. Both Phe and Tyr are hydrophobic aromatic amino acids comparing to Asn, which is slightly hydrophilic with an amide side chain. Since Phe and Tyr have obviously larger steric factors than Asn (steric factor: Asn: $117.7 \AA$, Phe 189.9 $\AA$ and Tyr: $193.6 \AA$ ), we could derive the information about whether the neighboring side chain of the metal binding group involved interference in its access to the divalent cation pocket and finally affected the activity of PHSXX' peptides.

Analogues for PHSRN (agonist to cell adhesion): PHSRF, PHSRY

Analogues for PHSCN (antagonist to cell adhesion): PHSCF, PHSCY.

Peptides shown in Table 3 were prepared parallely in the fritted syringes, which were set up on the drain and wash block. Dried MBHA resin was loaded and swollen in syringes. Each peptide was synthesized by a series of Boc cycles on the MBHA resin, and was cleaved by HF simultaneously after peptide chain elongation. The peptides were 
purified by $\mathrm{C}-18$ column chromatography under water/ acetonitrile stepwise elution. The identity of the peptide was confirmed by MALDI-TOF mass spectroscopy, which showed the presence of the pseudomolecular ion $[\mathrm{m}+\mathrm{H}]^{+}$.

\section{Biological Activity Tests of Peptide Analogues Ac-PHSXX'N-NH}

Peptide analogues (1-6 and 8-12) were tested in an ex vivo ring angiogenesis assay and the results were summarized in Table 4. First, aortic arches were removed from chicken eggs at day 14 of embryonic development and individual peptide was applied to small pieces of aortic rings. The aortic ring sprouting was detected and the change of the diameter of the aortic ring was recorded at $24 \mathrm{~h}$ and $48 \mathrm{~h}$, respectively. Most of the peptides were tested once, some of them were tested twice and some experimental results were not reproducible. In some cases, the inconsistent nature of the assay results made it impossible for us to make any definitive conclusion about the biological activity of these peptides. The hydroxamate peptide Ac-PHSE(NHOH)N-NH $\mathrm{N}_{2}$ was shown to be inhibitory, Ac-PHSD(NHOH)N-NH 2 and Ac-PHSE(NHOH)L-NH $\mathrm{NH}_{2}$ were inactive. Whether the metal binding group was involved in cell inductive invasion activity as its effect on angiogenesis activity will require further verification, perhaps using a more robust assay procedure. 
Table 3 Summary of Ac-PHSXX'- $\mathrm{NH}_{2}$ peptides analogues in solid phase peptide synthesis Boc chemistry (peptides 7-12 were prepared by parallel peptide synthesis)

\begin{tabular}{|c|c|c|c|c|c|}
\hline No & Peptide & $\begin{array}{l}\text { Peptide content in } \\
\text { crude peptide }(\%)^{\mathrm{a}}\end{array}$ & $\begin{array}{l}\text { Yield } \\
(\%)^{b}\end{array}$ & MW cald & $\begin{array}{l}M W+1 \\
\text { found }^{c}\end{array}$ \\
\hline 4 & Ac-PHSRN-NH ${ }_{2}$ & 94 & 89 & 650.3 & 651.4 \\
\hline 5 & Ac-PHSCN-NH & 82 & 77 & 597.4 & 598.4 \\
\hline 6 & Ac-PHSSN-NH ${ }_{2}$ & 93 & 56 & 581.5 & 582.7 \\
\hline 7 & Ac-PHSDN-NH ${ }_{2}$ & 78 & 69 & 609.7 & 610.6 \\
\hline 8 & Ac-PHSDF-NH ${ }_{2}$ & 80 & 73 & 642.7 & 643.8 \\
\hline 9 & Ac-PHSCF-NH ${ }_{2}$ & 78 & 72 & 630.8 & 631.8 \\
\hline 10 & Ac-PHSRF-NH ${ }_{2}$ & 85 & 82 & 683.8 & 684.8 \\
\hline 11 & Ac-PHSCY-NH & 78 & 70 & 646.8 & 647.7 \\
\hline 12 & Ac-PHSRY-NH ${ }_{2}$ & 93 & 87 & 699.7 & 700.9 \\
\hline
\end{tabular}

${ }^{a}$ Determined by RP-HPLC at $\lambda=220 \mathrm{~nm}$. ${ }^{b}$ Calculated after RP-HPLC purification according to the initial substitution level $(1.25 \mathrm{meq} / \mathrm{g})$ on the pMBHA resin. ${ }^{c}$ Obtained by MALDI-TOF MS 
Table 4 Ac-PHSXX'- $\mathrm{NH}_{2}$ peptides ex vivo ring angiogenesis assay, $200 \mu \mathrm{g} / \mathrm{mL}$ at $24 \mathrm{~h}$ and $48 \mathrm{~h}$

\begin{tabular}{|c|c|c|c|c|c|c|c|}
\hline \multirow{3}{*}{ Peptide } & \multicolumn{7}{|c|}{ Average aorta diameter $(\mathrm{cm})$} \\
\hline & \multicolumn{3}{|c|}{ Experiment I } & \multicolumn{2}{|c|}{ Experiment II } & \multicolumn{2}{|c|}{ Experiment III } \\
\hline & $24 \mathrm{~h}$ & $48 \mathrm{~h}$ & Conclusion $^{\mathrm{a}}$ & $48 \mathrm{~h}$ & Conclusion $^{\mathrm{b}}$ & $48 \mathrm{hr}$ & Conclusion $^{\mathrm{c}}$ \\
\hline Ac-PHSRN-NH ${ }_{2}$ & 0 & 0 & Inhibitory & - & - & - & - \\
\hline Ac-PHSRF-NH ${ }_{2}$ & 0.47 & 1.22 & Active++ & 0.75 & Inactive & - & - \\
\hline Ac-PHSRY-NH ${ }_{2}$ & 0.08 & 0.53 & Inactive & - & - & - & - \\
\hline Ac-PHSCF-NH ${ }_{2}$ & 0.72 & 1.41 & Active +++ & - & - & - & - \\
\hline Ac-PHSCY-NH ${ }_{2}$ & 0.34 & 0.91 & Active+ & 1.42 & Active + & - & - \\
\hline Ac-PHSCN-NH ${ }_{2}$ & - & - & - & - & - & 0.07 & Inhibitory \\
\hline Ac-PHSSN-NH 2 & 0.52 & 1.02 & Active + & 0.84 & Inactive & - & - \\
\hline Ac-PHSDF-NH ${ }_{2}$ & 0.23 & 0.82 & Inactive & 1.51 & Active + & - & - \\
\hline Ac-PHSE(NHOH)N-NH & 0 & 0 & Inhibitory & - & - & - & - \\
\hline Ac-PHSD(NHOH)N-NH & - & - & - & - & - & - & - \\
\hline Ac-PHSE(NHOH)L-NH ${ }_{2}$ & 0.12 & 0.54 & Inactive & - & - & 0.93 & Inactive \\
\hline
\end{tabular}

The data was provided by Hynda K. Kleinman.

Conclusion was drawn by comparing the data with a: negative control values: $0.42 \mathrm{~cm}(24 \mathrm{~h}$ reading $)$ and $0.70 \mathrm{~cm}(48 \mathrm{~h}$ reading) and positive control values: $2.03 \mathrm{~cm}$ ( $24 \mathrm{~h}$ reading) and $3.71 \mathrm{~cm}(48 \mathrm{~h}$ reading); b: negative control value: $0.81 \mathrm{~cm}(48 \mathrm{~h}$ reading) and positive control value: $2.70 \mathrm{~cm}(48 \mathrm{~h}$ reading); c: negative control value: $0.86 \mathrm{~cm}$ ( $48 \mathrm{~h}$ reading) and positive control value: $2.80 \mathrm{~cm}$ ( $48 \mathrm{~h}$ reading). 


\section{Conclusion}

In our study two new hydroxamate aspartic acid and glutamic acid building blocks were synthesized with high purity and good yield. The failure of these $\mathrm{N}^{\alpha}$ protected amino acids in coupling reactions was due to an intramolecular cyclization giving succinimide formation. Therefore the hydroxamate peptides were prepared indirectly using solid phase hydroxamate peptide synthesis method (Chen and Spatola, 1997). The side chain carboxyl group of a peptide synthesized on paramethylbenzhydrylamine (pMBHA) resin was converted to a hydroxamate functional group by condensing with $\mathrm{NH}_{2} \mathrm{OBn}$, and the $\mathrm{OBn}$ group was removed during $\mathrm{HF}$ cleavage of the peptide resin. Severe aspartimide formation was observed in the synthesis of Ac-PHSD(NHOH)N-NH , and several modifications were made to the original hydroxamate peptide synthesis. Neighboring asparagine was introduced with bulky side chain protecting group; piperidine was replaced with piperazine to remove $N^{\alpha}$-Fmoc group; side chain modification was made after peptide chain elongation and the resin was neutralized before $\mathrm{N}-\mathrm{C}$ coupling and the aspartimide formation was inhibited effectively with the optimized method. All Ac-PHSXX' $-\mathrm{NH}_{2}$ analogues were prepared by solid phase peptide synthesis method and examined by a ring angiogenesis assay by Dr. Kleiman at the institute $\mathrm{NIH}$. Hydroxamate analogue Ac-PHSE(NHOH)N-NH${ }_{2}$ showed the expected angiogenesis inhibition activity, however, peptide Ac- $\mathrm{PHSD}(\mathrm{NHOH}) \mathrm{N}^{-\mathrm{NH}_{2}}$ which is one $\mathrm{CH}_{2}$ short on the hydroxamate amino acid side chain turned out to be inactive. Therefore, whether hydroxamate group affected the ring sprouting activity could not be determined in these experiments and whether peptide binding the divalent pocket to influence cell invasion need be tested further. Peptides with an aromatic amino acid at 
position 5 were found to be active with Ac-PHSCY-NH 2 providing approximately as active as Ac-PHSRF-NH 2 .

\section{E. Experimental Section}

Instruments and materials

The analytical reversed phase-high performance liquid chromatography (RPHPLC) was performed on a Vydac $218 T$ T5 $4 \mathrm{C}_{18}$ column $(4.6 \times 250 \mathrm{~mm})$ on a Hitachi 655A system equipped with an L-5000 controller and D-2000 integrator. Peptides were eluted with the following gradient system: $5-90 \% \mathrm{CH}_{3} \mathrm{CN} /$ water with a constant concentration of TFA $(0.05 \% \mathrm{v} / \mathrm{v})$ in $30 \mathrm{~min}$, flow $1.0 \mathrm{~mL} / \mathrm{min}$ and the separation was monitored by UV detector set at $220 \mathrm{~nm}$. HF cleavage of peptides from resin was carried out in a Kel-F HF apparatus (Peptide Institute, Osaka). The molecular weight of the peptide was verified by MALDI-TOF MS and all the calculated molecular weights represent the exact molecular weight in this chapter. TLC was performed on Merck 254 plates using the following solvent system:
A: $n$ - $\mathrm{BuOH}: \mathrm{H}_{2} \mathrm{O}: \mathrm{AcOH}, 4: 1: 1$
B: EtOH: Hexane $\quad 1: 1$
C: $\mathrm{CHCl}_{3}: \mathrm{EtOH}: \mathrm{AcOH} \quad 85: 10: 5$

The pMBHA resin (1.2 meq/g) was a gift from Peptides International (Louisville). BOP coupling reagent was purchased from Advanced Chem Tech (Louisville). All other reagents were reagent grade and were used without further purification.

1. Preparation of Boc-Asp(NHOBn)-OFm and Boc-Glu(NHOBn)-OFm

(1) Preparation of Boc-Asp-OH, $\mathrm{N}^{\alpha}$ - (t-butyloxycarbonyl) aspartic acid(13) 
L-Aspartic acid (10 g, $75.1 \mathrm{mmol})$ and sodium hydroxide $(6 \mathrm{~g}, 150 \mathrm{mmol})$ were dissolved in dioxane-water $(1: 1)$ solution $(60 \mathrm{~mL})$. The solution was chilled with an ice bath for $15 \mathrm{~min}$. Boc anhydride $(21 \mathrm{~g}, 96.2 \mathrm{mmol})$ in $15 \mathrm{~mL}$ dioxane was added to the aspartic acid solution dropwise while stirring and the solution temperature was controlled under $0^{\circ} \mathrm{C}$. After the addition of $(\mathrm{Boc})_{2} \mathrm{O}$, the ice bath was removed and the reaction stirred at ambient temperature for 72 hours. During the reaction process, sodium hydroxide $(6 \mathrm{~g}, 150 \mathrm{mmol})$ was added to maintain the $\mathrm{pH}$ above 10 . The dioxane was removed by evaporation. The remaining aqueous solution was washed with diethyl ether $(2 \times 50 \mathrm{~mL})$ and adjusted to $\mathrm{pH} 2$ by $4 \mathrm{~N} \mathrm{HCl}$ aqueous solution. Ethyl acetate $(4 \times 70 \mathrm{~mL})$ was used to extract Boc-Asp-OH. The organic layers were combined and washed with water $(2 \times 40 \mathrm{~mL})$ and saturated brine solution $(2 \times 40 \mathrm{~mL})$, then dried by $\mathrm{MgSO}_{4}$. The solvent was evaporated and the product was recrystallized from ethyl acetatehexane.

Yield: $16 \mathrm{~g}(98 \%)$

Rf: 0.7 (solvent A)

m.p.: $115-117^{\circ} \mathrm{C}$

$1 \mathrm{H}-\mathrm{NMR}\left(\mathrm{CDCl}_{3}\right) \delta \mathrm{ppm}: 1.43(\mathrm{~s}, 9 \mathrm{H}) ; 2.84(\mathrm{dd}, 1 \mathrm{H}), 3.10(\mathrm{dd}, 1 \mathrm{H}) ; 4.61(\mathrm{~m}, 1 \mathrm{H})$ $5.67(\mathrm{dd}, 1 \mathrm{H})$

(2) Preparation of Boc-Aspartic Acid Anhydride (14)

DCC (14.6 g, $70.8 \mathrm{mmol}$ ) was dissolved in $20 \mathrm{~mL}$ ethyl acetate and added portionwise to a stirred solution of Boc-Asp-OH $(15 \mathrm{~g}, 64.4 \mathrm{mmol})$ in ethyl acetate (40 $\mathrm{mL}$ ) at $0^{\circ} \mathrm{C}$. The reaction mixture was stirred in ice bath for $1 \mathrm{hr}$ and then at ambient temperature for another hour. DCU precipitated from the reaction was filtered and the 
solvent evaporated to dryness. Boc-aspartic acid anhydride (14.5 g) was obtained and directly used in the next step of reaction.

(3) Preparation of Boc-Asp-OFm, $N^{\alpha}-$ (t-butyloxycarbonyl) aspartic $\alpha$ fluorenylmethyl ester(15)

Boc-aspartic acid anhydride (14.5 g) was dissolved in anhydrous THF (45 mL). 9fluorenylmethanol $(12.6 \mathrm{~g}, 64.4 \mathrm{mmol})$ and DIEA (10.9 $\mathrm{mL}, 64.4 \mathrm{mmol})$ were added to the reaction solution respectively and the reaction was stirred overnight. The solvent was removed by evaporation and the remaining oily product was dissolved by $40 \mathrm{~mL}$ EtOAc. The organic phase was washed by $1 \mathrm{~N} \mathrm{HCl}(3 \times 30 \mathrm{~mL}), \mathrm{NaHCO}_{3}(3 \times 30 \mathrm{~mL})$, water $(3 \times$ $30 \mathrm{~mL})$ and brine $(3 \times 30 \mathrm{~mL})$. Finally the EtOAc solution was dried over $\mathrm{MgSO}_{4}$. The product contained both $\alpha$ and $\beta$ isomers and the desired $\alpha$-fluorenylmethyl ester was the predominant in mixture $(67 \%: 33 \%)$ and was obtained by recrystallization from the solvent of EtOAc : hexane (2:1).

Yield: $12 \mathrm{~g}$ (47\% from L-aspartic acid)

Rf: 0.4 (solvent B)

m.p.: $163-164^{\circ} \mathrm{C}$

1H-NMR $\left(\mathrm{CD}_{3} \mathrm{CN}\right) \delta \mathrm{ppm} 1.46(\mathrm{~s}, 9 \mathrm{H}) ; 2.74(\mathrm{~m}, 2 \mathrm{H}) ; 4.28(\mathrm{~m}, 1 \mathrm{H}) ; 4.43-4.47(\mathrm{~m}$, $2 \mathrm{H}) ; 4.58(\mathrm{~m}, 1 \mathrm{H}) ; 5.82(\mathrm{dd}, 1 \mathrm{H}) ; 7.36-7.88(\mathrm{~m}, 8 \mathrm{H})$

(4) Preparation of Boc-Glu(OBn)-OFm, $N^{\alpha}$ - (t-butyloxycarbonyl) glutamic $\alpha$ fluorenylmethyl, g-benzyl ester (16)

The synthesis started from $\mathrm{N}^{\alpha}$ - (t-butyloxycarbonyl)-g-(benzyl ester)-L-glutamic acid. Boc-Glu(OBn)-OH (6 g, $18 \mathrm{mmol})$, fluorenylmethanol $(3.9 \mathrm{~g}, 20 \mathrm{mmol})$ were dissolved in $50 \mathrm{~mL}$ EtOAc with $1.46 \mathrm{~mL}(18 \mathrm{mmol})$ pyridine. Boc-anhydride $(4.7 \mathrm{~g}, 21.6$ 
mmol) in EtOAc was added to the mixture and allowed to react for $40 \mathrm{~h}$. Boc-anhydride $(1.9 \mathrm{~g}, 8.7 \mathrm{mmol})$ was introduced to the reaction mixture after $20 \mathrm{~h}$ to process the reaction completely. The reaction was monitored by TLC and stopped when the starting material spot disappeared on TLC plate. Working up involved washing the mixture by $5 \%$ $\mathrm{NaHCO}_{3}(3 \times 30 \mathrm{~mL})$, water $(2 \times 20 \mathrm{~mL}), 10 \% \mathrm{KHSO}_{4}(2 \times 20 \mathrm{~mL})$ and $\mathrm{NaCl}(20 \mathrm{~mL})$ and drying over the $\mathrm{NaSO}_{4}$. After removing the organic solvent by evaporation, the product was crystallized in $20 \mathrm{~mL}$ methanol. The sample was obtained as white solid in $7.5 \mathrm{~g}$ and the yield was $81.3 \%$.

Rf: 0.8 (solvent C)

m.p.: $96-97^{\circ} \mathrm{C}$

1H-NMR (DMSO-d $\left.{ }_{6}\right) \delta$ ppm: $1.34(\mathrm{~s}, 9 \mathrm{H}) ; 1.68-1.82(\mathrm{~m}, 2 \mathrm{H}), 2.28-2.36(\mathrm{~m}, 2 \mathrm{H})$ $4.02-4.43(\mathrm{~m}, 4 \mathrm{H}), 5.06(\mathrm{~s}, 2 \mathrm{H}), 7.23-7.88(\mathrm{~m}, 14 \mathrm{H})$

(5) Preparation of Boc-Glu-OFm, $N^{\alpha}$ - (t-butyloxycarbonyl) glutamic $\alpha$ fluorenylmethyl ester(17)

Boc-Glu(OBn)-OFm $(6.6 \mathrm{~g}, 12.8 \mathrm{mmol})$ was dissolved in $75 \mathrm{~mL}$ methanol, water and acetic acid (6:1:1) solvent. $20 \mathrm{mg} 10 \% \mathrm{Pd} / \mathrm{C}$ was added in the mixture. The reaction flask was flushed by nitrogen for three minutes before introducing hydrogen. BocGlu(OBn)-OFm was hydrogenated for three hours until the TLC analysis showed completion of the reaction. After the catalyst was filtered off and the filtrate was evaporated, the oily product was crystallized by hexane. After washing the crystallized product by hexane $(3 \times 10 \mathrm{~mL}), 3.8 \mathrm{~g}$ pure product was obtained. Yield: $70 \%$

Rf: 0.5 (solvent C)

mp: $95-97^{\circ} \mathrm{C}$ 
1H-NMR (DMSO-d6) $\delta$ ppm: 1.34 (s, 9H); 1.68-1.88 (m, 2H), 2.28-2.56 (m, 2H),

4.12-4.88 (m, 4H), 7.29-7.88 (m, 9H), $12.0(\mathrm{~s}, 1 \mathrm{H})$

(6) Preparation of Boc-Asp(NHOBn)-OFm, $N^{\alpha}$ - (t-butyloxycarbonyl) aspartic $\alpha$-fluorenylmethyl, $\beta$-O-benzyl hydroxamate ester (18)

Boc-Asp-OFm (14.6 mmol, $6 \mathrm{~g})$ and BOP (14.6 mmol, $2.33 \mathrm{~g})$ were dissolved in $50 \mathrm{~mL}$ dichloromethane. O-benzylhydroxylamine hydrogen chloride (14.6 mmol, $2.33 \mathrm{~g})$ was added to the mixture as the solid, which was dissolved after introducing DIEA (29.2 mmol, $5.07 \mathrm{~mL}$ ). The reaction was then maintained at room temperature for $9 \mathrm{~h}$. The solvent was evaporated and EtOAc $(30 \mathrm{~mL})$ was added to the remaining oil. The organic solution was washed by $1 \mathrm{~N} \mathrm{HCl}(3 \times 20 \mathrm{~mL})$, saturated $\mathrm{NaHCO}_{3}(3 \times 20 \mathrm{~mL})$, water $(3 \times$ $20 \mathrm{~mL}$ ) and brine $\left(3 \times 20 \mathrm{~mL}\right.$ ). The organic layer was dried by $\mathrm{MgSO}_{4}$ and after removing the EtOAc, the sample was crystallized in $10 \mathrm{~mL}$ hexane. The desired product was obtained in $6.3 \mathrm{~g}$ (yield: $90 \%$ ).

Rf: 0.7 (solvent B)

m.p.: $107-109^{\circ} \mathrm{C}$

1H-NMR $\left(\mathrm{CD}_{3} \mathrm{CN}\right) \delta \mathrm{ppm}: 1.46(\mathrm{~s}, 9 \mathrm{H}) ; 2.56(\mathrm{~m}, 2 \mathrm{H}) ; 4.28(\mathrm{~m}, 1 \mathrm{H}) ; 4.43-4.47$

$(\mathrm{m}, 2 \mathrm{H}) ; 4.58(\mathrm{~m}, 1 \mathrm{H}) ; 4.82(\mathrm{~s}, 2 \mathrm{H}), 5.84(\mathrm{~b}, 1 \mathrm{H}) ; 7.36-7.88(\mathrm{~m}, 13 \mathrm{H}) ; 9.36(\mathrm{~s}, 1 \mathrm{H})$

(7) Preparation of Boc-Glu(NHOBn)-OFm, $N^{\alpha}-\quad$ ( $t$-butyloxycarbonyl) glutamic $\alpha$-fluorenylmethyl, g-O-benzyl hydroxamate ester (19)

Boc-Glu-OFm (4.7 mmol, $2 \mathrm{~g})$ and BOP (4.7 mmol, $2.1 \mathrm{~g})$ were dissolved in 20 $\mathrm{mL}$ DCM. O-benzylhydroxyl amine hydrogen chloride $(4.7 \mathrm{mmol}, 0.57 \mathrm{~g})$ was added to the mixture as solid, which was dissolved after introducing DIEA $(9.4 \mathrm{mmol}, 1.62 \mathrm{~mL})$ and the reaction mixture was stirred for $6 \mathrm{hr}$ in room temperature. The solvent was 
evaporated and the oily product was dissolved by $15 \mathrm{~mL}$ EtOAc and the organic layer was washed by $3 \times 10 \mathrm{~mL} 1 \mathrm{~N} \mathrm{HCl}, 3 \times 10 \mathrm{~mL}$ saturated $\mathrm{NaHCO}_{3}, 3 \times 10 \mathrm{~mL}$ water and 3 x $10 \mathrm{~mL}$ brine. The organic solution was dried with $\mathrm{Na}_{2} \mathrm{SO}_{4}$ and after removing the EtOAc, the sample was crystallized in $10 \mathrm{~mL}$ hexane. The expected product was obtained in $2.3 \mathrm{~g}$ with the yield was $92 \%$.

Rf: 0.7 (solvent B)

m.p.: $95-97^{\circ} \mathrm{C}$

1H-NMR $\left(\mathrm{CD}_{3} \mathrm{CN}\right) \delta \mathrm{ppm}: 1.46(\mathrm{~s}, 9 \mathrm{H}) ; 1.72(\mathrm{~m}, 1 \mathrm{H}), 1.83(\mathrm{~m}, 1 \mathrm{H}), 2.05(\mathrm{~m}, 2 \mathrm{H})$;

$3.88(\mathrm{~m}, 1 \mathrm{H}) ; 4.44(\mathrm{~m}, 2 \mathrm{H}) ; 4.54(\mathrm{~m}, 1 \mathrm{H}) ; 4.81(\mathrm{~s}, 2 \mathrm{H}), 5.84(\mathrm{dd}, 1 \mathrm{H}) ; 7.36-7.88$

$(\mathrm{m}, 13 \mathrm{H}) ; 9.36(\mathrm{~s}, 1 \mathrm{H})$

2. Preparation of Boc-Asp(NHOBn)-OH and Boc-Glu(NHOBn)-OH

(1) Preparation of Boc-Asp(NHOBn)-OH, $N^{\alpha}$ - (t-butyloxycarbonyl) aspartic $\beta$-O-benzyl hydroxamate ester (20)

Boc-Asp(NHOBn)-OFm (2.1 g, $4.1 \mathrm{mmol})$ was dissolved in $30 \mathrm{~mL} 25 \%(\mathrm{v} / \mathrm{v})$ piperidine in THF and allowed to react for $35 \mathrm{~min}$ in room temperature. After THF removing, the remaining oil drop was dissolved by $25 \mathrm{~mL}$ saturated $\mathrm{NaHCO}_{3}$ solution. The aqueous layer was washed with $20 \mathrm{~mL}$ EtOAc for three times before adjusted to $\mathrm{pH}$ 2 by $1 \mathrm{~N} \mathrm{HCl}$ acidification. The product was extracted from the water layer by $3 \times 30 \mathrm{~mL}$ EtOAc and dried over $\mathrm{MgSO}_{4}$. The organic solvent was evaporated and $700 \mathrm{mg}$ greasy product was obtained. The yield was $51 \%$.

Rf: 0.6 (solvent B)

mp: $70-72^{\circ} \mathrm{C}$ 
1H-NMR (DMSO-d $\left.\mathrm{d}_{6}\right) \delta \mathrm{ppm}: 1.40(\mathrm{~s}, 9 \mathrm{H}) ; 2.30(\mathrm{~m}, 1 \mathrm{H}) ; 2.42(\mathrm{~m}, 1 \mathrm{H}) ; 4.32(\mathrm{~m}$,

$1 \mathrm{H}) ; 4.79(\mathrm{~s}, 2 \mathrm{H}) ; 6.98(\mathrm{~b}, 1 \mathrm{H}) ; 7.38(\mathrm{~m}, 5 \mathrm{H}) ; 11.02(\mathrm{~s}, 1 \mathrm{H})$

(2) Preparation of Boc-Glu(NHOBn)-OH, $N^{\alpha}$ - (t-butyloxycarbonyl) glutamic g-O-benzyl hydroxamate ester (21)

Boc-Glu(NHOBn)-OFm (3 g, $5.7 \mathrm{mmol})$ was dissolved in $30 \mathrm{~mL} 5 \%(\mathrm{w} / \mathrm{v})$ piperazine in THF and allowed to react for $30 \mathrm{~min}$. THF was evaporated, and the remaining oil drop was dissolved by $20 \mathrm{~mL}$ saturated $\mathrm{NaHCO}_{3}$ solution. The $\mathrm{NaHCO}_{3}$ layer was washed with $15 \mathrm{~mL}$ EtOAc for three times and acidified to $\mathrm{pH} 2$ with $1 \mathrm{~N} \mathrm{HCl}$. The product was extracted from the water layer by washing with $3 \times 20 \mathrm{~mL}$ EtOAc and dried over $\mathrm{MgSO}_{4}$. The organic solvent was evaporated and $1.3 \mathrm{~g}$ product was obtained. The yield was $65 \%$.

Rf: 0.6 (solvent B)

$\mathrm{mp} 54-56^{\circ} \mathrm{C}$

1H-NMR (DMSO-d 6 ) $\delta$ ppm: $1.38(\mathrm{~s}, 9 \mathrm{H}) ; 1.64(\mathrm{~m}, 1 \mathrm{H}) ; 1.88(\mathrm{~m}, 1 \mathrm{H}) ; 3.82(\mathrm{~m}$, $1 \mathrm{H}) ; 4.78(\mathrm{~s}, 2 \mathrm{H}) ; 7.01(\mathrm{~b}, 1 \mathrm{H}) ; 7.40(\mathrm{~m}, 5 \mathrm{H}) ; 11.02(\mathrm{~s}, 1 \mathrm{H})$ 
Table 5 Solid Phase Peptide Synthesis Protocol

\begin{tabular}{|c|c|c|c|c|}
\hline \multirow[b]{2}{*}{ Step } & \multicolumn{2}{|l|}{ Boc Chemistry } & \multicolumn{2}{|l|}{ Fmoc Chemistry } \\
\hline & Reagent & $\begin{array}{l}\text { Time } \\
(\min )\end{array}$ & Reagent & $\begin{array}{l}\text { Time } \\
(\mathrm{min})\end{array}$ \\
\hline Deprotection & $\begin{array}{l}\text { TFA/DCM/anisole } \\
(50 / 45 / 5, \mathrm{v} / \mathrm{v} / \mathrm{v} / \%)\end{array}$ & 30 & $\begin{array}{c}\text { Piperidine/DMF } \\
(1 / 4, v / v / \%)\end{array}$ & 30 \\
\hline Wash & $\begin{array}{c}\text { DCM } \\
\text { Methanol } \\
\text { DMF }\end{array}$ & $\begin{array}{l}3 \times 1 \\
2 \times 1 \\
3 \times 1\end{array}$ & $\begin{array}{c}\text { DMF } \\
\text { Methanol } \\
\text { DMF }\end{array}$ & $\begin{array}{l}3 \times 1 \\
2 \times 1 \\
3 \times 1\end{array}$ \\
\hline Kaiser Test & Kaiser test reagents & $5 * *$ & Kaiser test reagents & $5 * *$ \\
\hline Coupling & $\begin{array}{c}\text { Boc-A.A (3 eq) } \\
\text { Coupling Reagent ( } 3 \text { eq) } \\
\text { DIEA ( } 6 \text { eq) }\end{array}$ & 60 & $\begin{array}{c}\text { Fmoc-A.A (3 eq) } \\
\text { Coupling Reagent }(3 \mathrm{eq}) \\
\text { DIEA }(6 \mathrm{eq})\end{array}$ & 60 \\
\hline Wash & $\begin{array}{c}\text { DMF } \\
\text { Methanol } \\
\text { DCM }\end{array}$ & $\begin{array}{l}3 \times 1 \\
2 \times 1 \\
3 \times 1\end{array}$ & $\begin{array}{c}\text { DMF } \\
\text { Methanol } \\
\text { DMF }\end{array}$ & $\begin{array}{l}3 \times 1 \\
2 \times 1 \\
3 \times 1\end{array}$ \\
\hline Kaiser Test & Kaiser test reagents & $5^{* * *}$ & Kaiser test reagents* & $5 * * *$ \\
\hline
\end{tabular}

* Kaiser test reagents:

$12 \mathrm{~mL} 0.01 \mathrm{MKCN} 100 \mathrm{~mL}$ pyridine

$2500 \mathrm{mg}$ ninhydrin in $10 \mathrm{~mL} n-\mathrm{BuOH}$

$3 \quad 80 \mathrm{~g}$ phenol in $20 \mathrm{~mL} n-\mathrm{BuOH}$

Removed a few milligrams of the peptide-resin with a spatula to a test tube and added 2-3 drops of Kaiser test reagents 1, 2 and 3. Placed the tube in $100^{\circ} \mathrm{C}$ water bath for five minutes.

**Positive result (resin beads turn blue or brown (in the case of proline)), do next coupling. Negative result (resin beads remain white), repeat the deprotection. 
${ }^{* * *}$ Negative result (resin beads remain white or yellow), go to next cycle. Positive result (resin beads turn blue or brown (in the case of proline)), repeat the coupling.

\section{Preparation of Ac-PHSXX'-NH2 sequences}

(1) Preparation of Ac-Pro-His-Ser-Arg-Asn- $-\mathrm{NH}_{2}$

(i) Preparation of H-Pro-His-Ser-Arg-Asn-MBHA resin (22)

Peptide synthesis started from the C-terminal amino acid being loaded on the polystyrene resin. The reaction was processed in the $80 \mathrm{~mL}$ reaction vessel, which was equipped with a frit on both ends. MBHA resin ( $4 \mathrm{~g}, 4.8 \mathrm{mmol}$, substitution $=1.2 \mathrm{meq} / \mathrm{g})$ was swelled in DIEA/DMF (1:9) solvent overnight. DMF solvent was filtered out. BocAsn-OH (3.34 g, $14.4 \mathrm{mmol})$, BOP (6.37 g, $14.4 \mathrm{mmol})$ and HOBt (1.95 g, $14.4 \mathrm{mmol})$ were dissolved in $30 \mathrm{~mL}$ anhydrous DMF with $5 \mathrm{~mL}, 28.8 \mathrm{mmol}$ DIEA. The mixture was poured into the reaction vessel and allowed to react for one hour. Afterwards, the unreacted amino acids and coupling reagents were filtered out with DMF solvent. The resin was washed with $3 \times 20 \mathrm{~mL}$ DMF, $2 \times 20 \mathrm{~mL}$ methanol and $3 \times 20 \mathrm{~mL}$ DCM. After a Kaiser test, the color of resin remained yellow, which showed the first amino acid was coupled to the resin completely. Mixed solvent TFA/DCM/anisol (45/50/5) $(30 \mathrm{~mL})$ was used to remove the $\mathrm{N}^{\alpha}$-Boc group. After $30 \mathrm{~min}$, the solvent was filtered out, and the resin was washed with $3 \times 20 \mathrm{~mL}$ DCM, $2 \times 20 \mathrm{~mL}$ methanol and $3 \times 20 \mathrm{~mL}$ DCM. Once again the Kaiser test was applied and the light yellow resin turned to dark blue color. So the Boc group was removed successfully and the resin was ready for next protected amino acid coupling.

By repeating the coupling and deprotection cycle according to the protocol in Table 5, reagents including Boc-Arg(Tos)-OH (6.14 g, $14.4 \mathrm{mmol})$, Boc-Ser(Bn)-OH 
(4.24 g, $14.4 \mathrm{mmol})$, Boc-His(Tos)-OH (5.88 g, $14.4 \mathrm{mmol})$ and Boc-Pro-OH (3.09 g, $14.4 \mathrm{mmol}$ ) were introduced to the resin one by one.

(ii) Preparation of Ac-Pro-His-Ser-Arg-Asn-MBHA resin (23)

The N-terminal resin (22) was acetylated by shaking with $2.26 \mathrm{~mL}(24 \mathrm{mmol})$ acetic anhydride in $30 \mathrm{~mL}$ DCM overnight. Finally the resin was filtered, and washed with $\mathrm{CH}_{2} \mathrm{Cl}_{2}(3 \mathrm{x}), \mathrm{MeOH}(2 \mathrm{x})$ and $\mathrm{CH}_{2} \mathrm{Cl}_{2}(3 \mathrm{x})$ and dried in vacuo.

(iii) Preparation of Ac-Pro-His-Ser-Arg-Asn- $\mathrm{NH}_{2}$ (4)

The dry peptide resin (23) was placed into the HF reaction vessel with $0.5 \mathrm{~mL}$ of anisole. The reaction vessel was hooked to HF apparatus and cooled in a dry ice/acetone bath for twenty minutes. The reaction vessel was evacuated and ready to collect $\mathrm{HF}$ liquid. Hydrogen fluoride $(20 \mathrm{~mL})$ was then condensed into the vessel and the reaction was allowed to proceed with stirring under an ice bath. After one hour reaction, HF was evaporated and the scavengers were extracted by washing with ethyl ether $30 \mathrm{~mL}$ for three times. The peptide was then extracted from the resin by $25 \%$ acetic acid and the acetic acid extract was lyophilized to provide the product as white powder (Yield: $2.78 \mathrm{~g}$, $89 \%)$.

RP-HPLC $\mathrm{R}_{\mathrm{t}}(\mathrm{min}): 5.07$

MALDI-MS: calc. $\left(\mathrm{C}_{26} \mathrm{H}_{42} \mathrm{~N}_{12} \mathrm{O}_{8}\right) 650.3$, found $(\mathrm{M}+\mathrm{H}): 651.6$

(2) Preparation of Ac-Pro-His-Ser-Cys-Asn- $\mathrm{NH}_{2}(\mathbf{5})$

MBHA resin (2 g, $2.4 \mathrm{mmol}$, substitution= $1.2 \mathrm{meq} / \mathrm{g})$ was swelled in DIEA/DMF: $1 / 9$ for 30min. Boc-Asn(Xan)-OH (3.96 g, 9.6 mmol), Boc-Cys(PMB)-OH (3.28 g, 9.6 mmol), Boc-Ser(Bn)-OH (2.83 g, 9.6 mmol), Boc-His(Tos)-OH (3.93 g, $9.6 \mathrm{mmol})$ and Boc-Pro-OH (2.06 g, $9.6 \mathrm{mmol})$ were coupled to the resin by following the classic Boc 
cycles. The coupling reagent in each cycle included BOP $(4.25 \mathrm{~g}, 9.6 \mathrm{mmol}), \mathrm{HOBt}(1.30$ g, $9.6 \mathrm{mmol})$ and DIEA ( $3.37 \mathrm{~mL}, 19.2 \mathrm{mmol})$. After HF cleavage, acetic acid extraction and lyophilize, peptide was obtained as white solid in $1.1 \mathrm{~g}$ (Yield 77\%).

RP-HPLC $R_{f}(\min ): 10.54$

MALDI-MS: calc. $\left(\mathrm{C}_{23} \mathrm{H}_{35} \mathrm{~N}_{9} \mathrm{O}_{8} \mathrm{~S}\right) 597.2$, found $(\mathrm{M}+\mathrm{H}): 598.5$

(a) Preparation of Boc-His(Tos)-OH (24)

Boc-His(Tos)-OH $\cdot$ DCHA $(2.2 \mathrm{~g}, 3.72 \mathrm{mmol})$ was suspended in $15 \mathrm{~mL}$ EtOAc. After $1 \mathrm{~N}$ ice cold $\mathrm{H}_{2} \mathrm{SO}_{4}(2.3 \mathrm{~mL}, 4.46 \mathrm{mmol})$ was added to the solution, the suspended amino acid was dissolved. The EtOAc layer was removed after being shaked with aqueous phase in the separatory funnel. The remained aqueous phase was washed with 20 $\mathrm{mL}$ EtOAC twice. All the organic solution wash combined and washed with $20 \mathrm{~mL}$ water for two times and dried under $\mathrm{Na}_{2} \mathrm{SO}_{4}$. The organic phase was evaporated to provide white solid in $1.46 \mathrm{~g}$. (Yield: 96\%).

(3) Preparation of Ac-Pro-His-Ser-Ser-Asn- $\mathrm{NH}_{2}(6)$

MBHA resin ( $1 \mathrm{~g}, 1.2 \mathrm{mmol}$, substitution= $1.2 \mathrm{meq} / \mathrm{g})$ was swelled in DIEA/DCM: 1/9 overnight. The Boc-Asn-OH (0.84 g, $3.6 \mathrm{mmol})$, Boc-Ser(Bn)-OH (1.06 g, $3.6 \mathrm{mmol})$, Boc-Ser(Bn)-OH (1.06 g, $3.6 \mathrm{mmol})$, Boc-His(Tos)-OH (1.46 g, $3.6 \mathrm{mmol})$ which was recovered from Boc-His(Tos)-OH - DCHA, and Boc-Pro-OH (1.21 g, 3.6 mmol) were coupled to the resin by following the classic Boc cycles. BOP (1.59 $\mathrm{g}, 3.6$ mmol), HOBt $(0.48 \mathrm{~g}, 3.6 \mathrm{mmol})$ and DIEA $(1.25 \mathrm{~mL}, 7.2 \mathrm{mmol})$ were used as coupling reagents in each cycle. After HF cleavage, white flake was obtained in $380 \mathrm{mg}$ (Yield: $55 \%)$.

RP-HPLC Rt (min): 18.27 
MALDI-MS: calc. $\left(\mathrm{C}_{22} \mathrm{H}_{34} \mathrm{~N}_{8} \mathrm{O}_{8} \mathrm{~S}\right) 581.3$, found $(\mathrm{M}+\mathrm{H}): 582.7$

(4) Parallel synthesis: Ac-Pro-His-Ser-Asp-Asn- $\mathrm{NH}_{2}$ (7), Ac-Pro-His-SerAsp-Phe- $\mathrm{NH}_{2}$ (8), Ac-Pro-His-Ser-Arg-Phe- $\mathrm{NH}_{2}$ (10), Ac-Pro-His-Ser-Arg-Try$\mathrm{NH}_{2}$ (12), Ac-Pro-His-Ser-Cys-Phe- $\mathrm{NH}_{2}$ (9) and Ac-Pro-His-Ser-Cys-Tyr- $\mathrm{NH}_{2}$ (11).

The protected amino acids used in the parallel peptide synthesis including: BocAsn-OH (Chem-Impex), Boc-Phe-OH (Chem-Impex), Boc-Tyr(2,6-diCl-Bn)-OH (Bachem), Boc-Asp(OBn)-OH (Peninsular), Boc-Cys(Pmb)-OH (Bacham), Boc$\operatorname{Arg}(\mathrm{Tos})-\mathrm{OH}$ (Bacham), Boc-Ser(Bn)-OH (Chem-Impex), Boc-His(Tos)-OH (recovered from Boc-His(Tos)-OH - DCHA which was purchased from Bacham) and Boc-Pro-OH (Bacham).

Dry MBHA resin (150 mg, $0.18 \mathrm{mmol}$ ) was weighed into six fitted syringes separately and the resin was swell in $6 \mathrm{~mL} \mathrm{10 \%} \mathrm{DIEA/} \mathrm{DMF} \mathrm{overnight.} \mathrm{The} \mathrm{amino} \mathrm{acids}$ were coupled to the resin by classic Boc chemistry. The amount and the adding sequence of Boc amino acids are summarized in Table 6. Each amino acid was dissolved in the DMF (6 mL) with BOP (238.9 mg, $0.54 \mathrm{mmol})$, HOBt $(72.9 \mathrm{mg}, 0.54 \mathrm{mmol})$ and DIEA $(0.19 \mathrm{~mL}, 1.08 \mathrm{mmol})$ before added to the resin. After completion of the chain building, the peptides were acetylated with $1.0 \mathrm{~mL}, 5.4 \mathrm{mmol}$ acetic anhydride in DMF.

The cleavages were achieved in the 24 chamber multiple HF apparatus. For each syringe, the resin was placed in a cleavage vessel with $0.5 \mathrm{~mL}$ anisole and $5 \mathrm{~mL}$ HF. The mixture was stirred at $0{ }^{\circ} \mathrm{C}$ for two hours before the HF was removed. The peptides were extracted with $30 \mathrm{~mL} 25 \%$ acetic acid and lyophilized to provide white to light yellow solid. Yield: $70 \%-89 \%$. 
Ac-PHSDN-NH 2 : RP-HPLC Rt (min): 10.56

MALDI-MS: calc. $\left(\mathrm{C}_{24} \mathrm{H}_{35} \mathrm{~N}_{9} \mathrm{O}_{10}\right) 609.3$, found $(\mathrm{M}+\mathrm{H}), 610.6$ Ac-PHSDF-NH 2 : RP-HPLC Rt (min): 12.77

MALDI-MS: calc. $\left(\mathrm{C}_{29} \mathrm{H}_{38} \mathrm{~N}_{8} \mathrm{O}_{9}\right) 642.3$, found $(\mathrm{M}+\mathrm{H}), 643.8$ Ac-PHSCF-NH $\mathrm{N}_{2}: \mathrm{RP}-H P L C \mathrm{R} t(\mathrm{~min}): 13.84$

MALDI-MS: calc. $\left(\mathrm{C}_{28} \mathrm{H}_{38} \mathrm{~N}_{8} \mathrm{O}_{7} \mathrm{~S}\right) 630.3$, found $(\mathrm{M}+\mathrm{H}), 631.8$ Ac-PHSRF-NH $\mathrm{N}_{2}: \mathrm{RP}-\mathrm{HPLC} \mathrm{Rt}(\mathrm{min}): 12.22$

MALDI-MS: calc. $\left(\mathrm{C}_{31} \mathrm{H}_{45} \mathrm{~N}_{11} \mathrm{O}_{7}\right) 683.4$, found $(\mathrm{M}+\mathrm{H}), 684.8$ Ac-PHSCY-NH $\mathrm{N}_{2}$ : RP-HPLC Rt (min): 12.52

MALDI-MS: calc. $\left(\mathrm{C}_{28} \mathrm{H}_{38} \mathrm{~N}_{8} \mathrm{O}_{8} \mathrm{~S}\right) 646.3$, found $(\mathrm{M}+\mathrm{H}), 647.7$ Ac-PHSRY-NH $2:$ RP-HPLC Rt (min): 11.19

MALDI-MS: calc. $\left(\mathrm{C}_{31} \mathrm{H}_{45} \mathrm{~N}_{11} \mathrm{O}_{8}\right) \quad 699.4$, found $(\mathrm{M}+\mathrm{H}), \quad 700.9$ 
Table 6 Boc-amino acid building block used in parallel synthesis peptide 7, 8, 9, 10, 11 and 12

Syringe 1: Ac-PHSDN-NH${ }_{2}$, Syringe 2: Ac-PHSDF-NH ${ }_{2}$, Syringe 3: Ac-PHSCF-NH $\mathrm{N}_{2}$, Syringe 5: Ac-PHSCY-NH

\begin{tabular}{|c|c|c|c|c|c|c|}
\hline $\begin{array}{l}\text { Amino Acids Added } \\
(0.54 \mathrm{mmol})\end{array}$ & Syringe 1 & Syringe 2 & Syringe 3 & Syringe 4 & Syringe 5 & Syringe 6 \\
\hline Boc-Asn-OH (125.4 mg) & Cycle $1^{*}$ & - & - & - & - & - \\
\hline Boc-Phe-OH (143.3 mg) & - & Cycle 1 & Cycle 1 & Cycle 1 & & \\
\hline $\begin{array}{c}\text { Boc-Try }(2,6-\mathrm{diCl}-\mathrm{Bn})-\mathrm{OH} \\
(237.7 \mathrm{mg})\end{array}$ & - & - & - & - & Cycle 1 & Cycle 1 \\
\hline Boc-Asp(OBn)-OH (174.6 mg) & Cycle 2 & - & - & - & - & - \\
\hline Boc-Cys(pmb)-OH (184.4 mg) & - & - & Cycle 2 & - & - & \\
\hline Boc-Arg(Tos)-OH (231.4 mg) & - & - & - & Cycle 2 & - & Cycle 2 \\
\hline Boc-Ser(Bn)-OH (158.9 mg) & Cycle 3 & Cycle 3 & Cycle 3 & Cycle 3 & Cycle 3 & Cycle 3 \\
\hline Boc-His(Tos)-OH (213.1 mg) & Cycle 4 & Cycle 4 & Cycle 4 & Cycle 4 & Cycle 4 & Cycle 4 \\
\hline Boc-Pro-OH (180.1 mg) & Cycle 5 & Cycle 5 & Cycle 5 & Cycle 5 & Cycle 5 & Cycle 5 \\
\hline
\end{tabular}

* Cycle means each cycle addressed in Table 5 
(5) Solid phase hydroxamate peptide synthesis of Ac-Pro-His-SerGlu(NHOH)-Leu- $\mathrm{NH}_{2}(\mathbf{1})$

(i) Preparation of Fmo-Glu(OtBu)-Leu-MBHA resin (25)

The reaction started from $200 \mathrm{mg}(0.19 \mathrm{mmol})$ of MBHA resin (substitution= 1.2 meq/g) swelled in DIEA/DCM: $1 / 9$ overnight. Boc-Leu-OH $(142.1 \mathrm{mg}, 0.57 \mathrm{mmol})$ was coupled to the resin with BOP (252.2 $\mathrm{mg}, 0.57 \mathrm{mmol}), \mathrm{HOBt}(77 \mathrm{mg}, 0.57 \mathrm{mmol})$ and DIEA $(0.20 \mathrm{~mL}, 1.14 \mathrm{mmol})$. TFA/DCM/anisol $(45 / 50 / 5)(10 \mathrm{~mL})$ was used to remove the $\mathrm{N}^{\alpha}$-Boc group. Fmoc-Glu(OtBu)-OH $(404.2 \mathrm{mg}, 0.95 \mathrm{mmol})$ was coupled to the resin with BOP (420.3 mg, $0.95 \mathrm{mmol}), \mathrm{HOBt}(128.4 \mathrm{mg}, 0.95 \mathrm{mmol})$ and DIEA (0.3 mL, 1.90 mmol).

(ii) Preparation of Fmo-Glu(NHOBn)-Leu-MBHA resin (26)

The $t$-Butyl group was removed by $10 \mathrm{~mL}$ TFA/ $\mathrm{CH}_{2} \mathrm{Cl}_{2} /$ anisole $(65 / 30 / 5)$ for 30 min and for three times in together. $\mathrm{NH}_{2} \mathrm{OBn} \cdot \mathrm{HCl}(151.6 \mathrm{mg}, 0.95 \mathrm{mmol})$ was coupled to the resin under the activation of coupling reagents BOP (420.3 mg, $0.95 \mathrm{mmol}), \mathrm{HOBt}$ (128.4 mg, $0.95 \mathrm{mmol})$ and DIEA (0.3 mL, $1.90 \mathrm{mmol})$.

(iii) Preparation of Ac-Pro-His(Trt)-Ser(tBu)-Glu(NHOBn)-Leu-MBHA resin (27)

Resin 26 was treated with $25 \%$ piperidine/DMF for $30 \mathrm{~min}$ and washed with DMF, MeOH and DCM. Fmoc-Ser(tBu)-OH (364.3 mg, $0.95 \mathrm{mmol})$ and Fmoc-His(Trt)$\mathrm{OH}(622.9 \mathrm{mg}, 0.95 \mathrm{mmol})$ and Fmoc-Pro-OH( $320.5 \mathrm{mg}, 0.95 \mathrm{mmol})$ were coupled to the resin one by one in classic Fmoc cycle. The coupling reagents used were BOP (420.3 $\mathrm{mg}, 0.95 \mathrm{mmol}), \mathrm{HOBt}(128.4 \mathrm{mg}, 0.95 \mathrm{mmol})$ and DIEA $(0.3 \mathrm{~mL}, 1.90 \mathrm{mmol})$ in $8 \mathrm{~mL}$ 
DMF. After Fmoc on Proline was removed, the peptide was acetylated shaking with 1 $\mathrm{mL}, 5.4 \mathrm{mmol}$ acetic anhydride and $0.5 \mathrm{~mL}, 2.8 \mathrm{mmol}$ DIEA in $10 \mathrm{~mL}$ DCM overnight.

(iv) Preparation of Ac-Pro-His-Ser-Glu(NHOH)-Leu- $\mathrm{NH}_{2}$ (1)

The dry hydroxamate peptide resin was put into a Kel-F HF apparatus and stirred with $5 \mathrm{~mL}$ anhydrous $\mathrm{HF}$ and $0.05 \mathrm{~mL}$ anisole at $0^{\circ} \mathrm{C}$ for $1 \mathrm{~h}$. $\mathrm{HF}$ was evaporated and the solid was washed with ether $(20 \mathrm{~mL} \mathrm{X} 3)$. The peptide was extracted by $25 \%$ acetic acid and crude peptide was obtained after lyophilization. The crude peptide was purified by running through $\mathrm{C}-18$ column and eluted with $10 \%$ acetonitrile, and purified peptide (94 $\mathrm{mg}$ ) was obtained, which can change $\mathrm{FeCl}_{3}$ test solution from yellow to red. Yield: $78 \%$.

RP-HPLC Rt (min): 12.1

MALDI-MS: calc. $\left(\mathrm{C}_{27} \mathrm{H}_{43} \mathrm{~N}_{9} \mathrm{O}_{9}\right) 637.3$, found $(\mathrm{M}+\mathrm{H}), 638.5$

(6) Ac-Pro-His-Ser-Glu(NHOH)-Asn- $\mathrm{NH}_{2}$ (2)

(i) Preparation of Boc-Asn-MBHA resin (28)

Boc-Asn-OH (132.4 mg, $0.57 \mathrm{mmol})$ was coupled to $200 \mathrm{mg}(0.19 \mathrm{mmol})$ the swelled MBHA resin with coupling reagents: BOP $(252.2 \mathrm{mg}, 0.57 \mathrm{mmol}), \mathrm{HOBt}(77.0$ $\mathrm{mg}, 0.57 \mathrm{mmol})$ and DIEA $(0.20 \mathrm{~mL}, 1.14 \mathrm{mmol})$.

(ii) Preparation of Ac-Pro-His-Ser-Glu(NHOH)-Asn- $\mathrm{NH}_{2}$ (2)

By following the method of peptide 1 synthesis, the peptide Ac-Pro-His(Trt)Ser(tBu)-Glu(NHOBn)-Asn-MBHA was prepared. After HF cleavage, crude peptide was obtained as brown solid in $110 \mathrm{mg}$. Purified compound $(97 \mathrm{mg})$ was collected as light yellow powder after chromatograph. Yield: $80 \%$.

RP-HPLC Rt (min): 5.35

MALDI-MS: calc. $\left(\mathrm{C}_{25} \mathrm{H}_{38} \mathrm{~N}_{10} \mathrm{O}_{10}\right) 638.3$, found $(\mathrm{M}+\mathrm{H}), 639.9$ 
(7) Ac-Pro-His-Ser-Asp(NHOH)-Asn- $\mathrm{NH}_{2}(3)$

(i) H-Pro-His(Trt)-Ser(tBu)-Asp(O'Bu)-Asn(Xan)-MBHA resin (29)

The reaction started from $200 \mathrm{mg}, 0.24 \mathrm{mmol}$ MBHA resin. Boc-Asn(Xan)-OH ( $296.3 \mathrm{mg}, 0.72 \mathrm{mmol}$ ) was coupled to the resin, and Boc group was removed by TFA/ $\mathrm{DCM} /$ anisole (50/ 45/ 5). Fmoc-Asp( $\left.\mathrm{O}^{\mathrm{t} B u}\right)-\mathrm{OH}(296.3 \mathrm{mg}, 0.72 \mathrm{mmol})$, Fmoc-Ser(tBu)$\mathrm{OH}(276.1 \mathrm{mg}, 0.72 \mathrm{mmol})$ and Fmoc-His(Trt)-OH $\cdot 0.6$ isopropanol $(472.1 \mathrm{mg}, 0.72$ $\mathrm{mmol})$ and Fmoc-Pro-OH $(242.9 \mathrm{mg}, 0.72 \mathrm{mmol})$ were coupled to the resin one by one in classic Fmoc cycle. BOP (318.6 mg, $0.72 \mathrm{mmol}), \mathrm{HOBt}(97.3 \mathrm{mg}, 0.72 \mathrm{mmol})$ and DIEA $(0.25 \mathrm{~mL}, 1.44 \mathrm{mmol})$ were included as coupling reagents in each cycle. Piperazine in DMF (6\% w/v) was used to deprotect Fmoc group after each coupling.

(ii) Ac-Pro-His-Ser-Asp(NHOBn)-Asn(Xan)-MBHA resin (30)

Acetic anhydride ( $1 \mathrm{~mL}, 5.4 \mathrm{mmol})$ was used to acetylize the peptide. The $t$-Butyl side chain protecting group of aspartic acid was removed by TFA/ DCM/ anisole (70/25/ 5) treatment for three times and $30 \mathrm{~min}$ each time, before the resin was coupled with $\mathrm{NH}_{2} \mathrm{OBn}(115 \mathrm{mg}, 0.72 \mathrm{mmol}), \mathrm{BOP}(318.6 \mathrm{mg}, 0.72 \mathrm{mmol}), \mathrm{HOBt}(97.3 \mathrm{mg}, 0.72$ mmol) and DIEA (0.25 mL, $1.44 \mathrm{mmol})$. The TFA deprotection also removed the Tos group on histidine and $t$-butyl group on serine.

(iii) Ac-Pro-His-Ser-Asp(NHOH)-Asn- $\mathrm{NH}_{2}$ (3)

HF cleavage of the peptide provided the crude product in $125 \mathrm{mg}$ as yellow solid. After chromatograph purification, $100 \mathrm{mg}$ light yellow powder was obtained. (Yield: 68\%)

RP-HPLC Rt (min): 4.11

MALDI-MS: calc. $\left(\mathrm{C}_{24} \mathrm{H}_{36} \mathrm{~N}_{10} \mathrm{O}_{10}\right) 624.3$, found $(\mathrm{M}+\mathrm{H}) 625.3$ 


\section{CHAPTER II}

\section{SYNTHESIS AND METAL BINDING STUDIES OF PEPTIDE SIDEROPHORE}

\section{ANALOGUES}

\section{A Introduction}

Metals have played an essential role in the evolution of every form of life on earth. However, most of the metal elements are present in non-utilizable inorganic forms, so nature has prepared vehicles to convey metals for living creatures. Ionophores are recognized as being one of the most special and efficient of such vehicles. Based on the Collins English Dictionary, an ionophore is "a chemical compound capable of forming a complex with an ion and transporting it through a biological membrane". Siderophores, natural ionophores which can bind iron and transfer it from an aqueous medium into a hydrophobic phase, have been the subject of intense research for many years.

\section{General Introduction of Siderophores}

Iron is required by most biological systems due to its diverse roles in the biochemistry of the cell. Although it is one of the most abundant elements on the planet, the bioavailability of iron is very poor, because the predominant form of iron occurs in its oxidized ferric [Fe(III)] state, which is highly insoluble at physiological $\mathrm{pH}$. To circumvent the solubility problem, many microbial, plants and even higher organisms secrete specific low molecular weight iron chelators called siderophores (iron carriers) to sequester and transport iron (Clarke, 2001). 
In nature, bacteria or neighboring microorganisms produce siderophores which chelate the iron from transferrin, lactoferrin or other iron-binding proteins (Clarke, 2001). The siderophore can then be transported into the cell (through the outer membrane, across the periplasm and inner membrane) via specific membrane-bound uptake systems. The whole transportation process involves a stereospecific and enantioselective recognition of the ferric complex by receptor proteins at the cell surface (Clarke, 2001).

Iron in its trivalent state has a $\mathrm{d}^{5}$ electronic configuration and the coordination requirements of iron(III) are best satisfied by six donor atoms ligating in an octahedral fashion to the metal center. Therefore, iron complexes are preferentially hexacoordinate, quasi octahedral. Fe(III) can form 1:3 complexes with bidentate ligands, 1:2 complexes with tridentate ligands, and a 1:1 complex with a hexadentate ligand. In siderophores, sixfold coordination is mostly achieved by trisbidentate ligands, because the complex can obtain the maximal thermodynamic stability by incorporating all six donors into a single molecular structure (Liu and Hider, 2002). Outstandingly stable iron complexes are formed with these hexadentate ligands: tricatecholate siderophores have complex formation constants up to $\log \mathrm{K}_{\mathrm{f}}=52$ (Harris, 1979), trihydroxamates have formation constants around $10^{30}\left[\mathrm{~L} \cdot \mathrm{mol}^{-1}\right]$, dihydroxamate/ carboxylates are about $10^{23}\left[\mathrm{~L} \cdot \mathrm{mol}^{-1}\right]$, and the constant for pure carboxylate is approximately $10^{21}\left[\mathrm{~L} \cdot \mathrm{mol}^{-1}\right]$ (Crumbliss, 1991) (Reid, 1993).

The donor atoms in ferric siderophore complexes are primarily oxygen and, rarely, heterocyclic nitrogen in accordance with HSAB (hard/soft-acid/base) principle. Since ferric ion is a hard acid which is preferentially linked to hard base atoms, such as oxygen, as coordination partners. On the other hand, iron(III) is a spherically symmetrical 
cation of radius $0.64 \AA$ with high charge density; therefore, it forms the most stable bonds with weakly polarizable oxygen atoms (Liu and Hider, 2002).

\section{Molecular Diversity of Siderophores}

More than a hundred naturally-occurring siderophores have currently been identified and characterized. These ligands involve two major functional groups: hydroxamates and catecholates. Ferrichrome, coprogen, ferrioxamine and rhodotorulic acid are representative hydroxamate siderophores. Also, phenolate siderophores include enterobactin, the strongest iron (III) chelator analogues, pyoverdins, pseudobactin, mycobactin and pyochelin (Miller, 1989).

(1) Hydroxamate Siderophores

Derived from Streptomyces pilosisand, desferrioxamine is the most well-known example among the hydroxamic acid siderophores (Figure 21). Desferrioxamine-B (clinically as Desferal ${ }^{\mathrm{TM}}$ ) has been widely used in treating hemochromatosis, acute iron poisoning (Cooley's anemia), and iron overload over the past 30 years (Miller, 1989). Desferrioxamine has three hydroxamate functional groups and behaves as a hexadentate ligand, forming a 1:1 (molar ratio) complex with iron. Additionally, desferrioxamine has a high selectivity towards iron(III) compared to other metal ions present in biological fluids, such as zinc, calcium and magnesium. However, the oral inactivity and rapid renal clearance of desferrioxamine make it less than an ideal therapeutic agent. Medicinal chemists are still investigating the appropriate way to improve the oral bioavailability of desferrioxamine, including prodrug preparation and backbone modifications. Metaphore Pharmaceuticals has developed solid-phase approaches to the synthesis of 
desferrioxamine variant libraries for high-throughput screening for their metal-binding properties (Marshall, 2002).

Figure 21 Structure of desferrioxamine B<smiles>CC(=O)N(O)CCCCCNC(=O)CCC(=O)N(O)CCCCCNC(=O)CCC(=O)N(O)CCCCCN</smiles>

\section{(2) Phenolate Siderophores}

With the highest reported iron-binding capacity of all siderophores, enterobactin is one of the best-studied siderophores. Originally isolated from E. coli and also found in many other enterobacteriaceae, enterobactin is a tricatecholate siderophore with a ferric complex formation constant of $10^{52}\left[\mathrm{~L} \cdot \mathrm{mol}^{-1}\right]$ (Pollack and Neilands, 1970). This siderophore is a cyclic triester of serine acylated with 2, 3-dihydroxybenzoic acid and three residues of dihydroxybenzoic acid provide the chelating groups (Figure 22) (Drechsel and Jung, 1998). 
Figure 22 Structure of enterobactin<smiles>O=C(N[C@@H](COC(=O)[C@H](COC(=O)[C@H](COC(=O)c1cccc(O)c1O)NC(=O)c1cccc(O)c1O)NC(=O)c1cccc(O)c1O)C(=O)O)c1cccc(O)c1O</smiles>

(3) Mixed Metal Binding Site Siderophores

Pyoverdins (also named pseudobactins), siderophores found in Pseudomonas aeruginosa, are potent $\mathrm{Fe}^{3+}$ chelators with complexing constants between $10^{24}$ and $10^{26}$ $\left[\mathrm{L} \cdot \mathrm{mol}^{-1}\right]$ at $\mathrm{pH}$ 7.0. Pseudomonas genus belong to the "fluorescent" sub-group in the rRNA homology group I of the family Pseudomonadaceae. The "fluorescents" derived their name from their ability to produce compounds under iron-deficient growth conditions showing a yellowish-green fluorescence (Budzikiewicz, 2001). The conspicuous fluorescence of pyoverdins arises from a chromophore with the core structure of 2, 3-diamino-6,7-dihydroxyquinoline (Figure 23). Pyoverdins are defined as mixed metal binding ligands, as those complexes contain metal binding sites including the catecholate group as a chromophore and two amino acids, hydroxamic acids and/ or hydroxycarboxylic acids as bidentate ligand sites. Compounds involved in this classification all have the common (1S)-5-amino-2,3-dihydro-8,9-dihydroxy-1H[1,2a]chinolin-1-carboxylic acid chromophore. Also common to these compounds is the substitution of the 5-amino group with different carboxylic acids, such as succinic acid, 
malic acid, 2-oxo-glutaric acid or glutamic acid the amine group of which could also be connected to a peptide chain with 6-12 amino acids (Drechsel and Jung, 1998).

The siderophores azotobactins and ferribactins show a high similarity to pyoverdins; by sharing the same peptidic component but having different chromophores. Azotobactin's chromophore has an imidazolone ring fused with a quinoline ring. Lacking the chromophore of pyoverdin, ferribactin contains a cyclization product of Tyr/Dab instead (Figure 23) (Drechsel and Jung, 1998).

Figure 23 Structure of pyoverdin, chromophores of pyoverdin, azotobactin and ferribactin

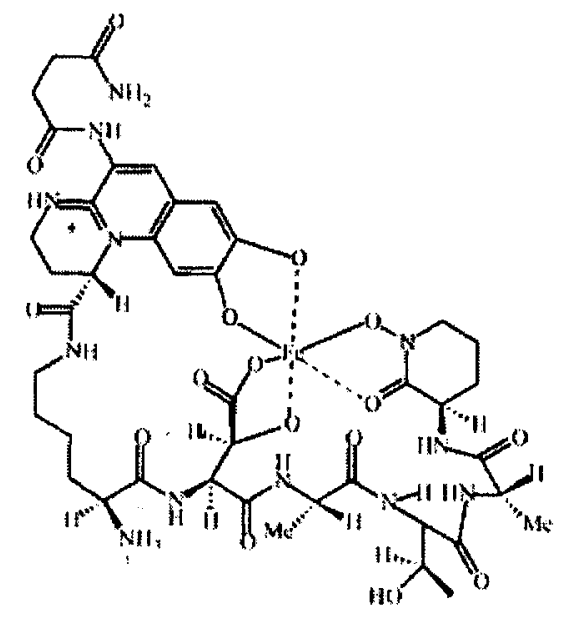

Pyoverdin<smiles></smiles><smiles>[R]C(=O)C1CCNC23NC(=O)NC(=Cc4cc(O)c(O)cc42)C13</smiles><smiles>[R]C(=O)C1CCN=C(C(Cc2ccc(O)cc2)NC(=C)CCC(N)C(=O)O)C1</smiles>

Chromophores of pyoverdins, azotobactins and ferribactins 
Mycobactins are a family of siderophores, which are isolated from mycobacteria including Mycobacterium tuberculosis and Mycobacterium phlei. This family promotes mycobacterial growth via iron uptake processes. From the general structure, one can see that mycobactins possess a nearly identical molecular metal binding site, including two hydroxamic acids and a 2-(2-hydroxyphenyl)-1,3-oxazoline residue serving as the iron chelator (Figure 24) and vary only in the stereochemistry of the chiral centers and in the peripheral groups (Hu, 1997). Based on Snow's findings, the three hydroxyl groups, chelated iron to form a stable complex which was necessary for mycobactin's biological activity. Loss of the growth inhibitory or stimulatory activity was observed for synthetic analogues without the hydroxyl groups. The long lipophilic side chain is essential for mycobactins to transport iron through cell membranes, making it a potential drug carrier (Snow, 1970; Snow, 1965).

Figure 24 Structure of Mycobactin<smiles>CC(=O)N(O)CC[C@H](NC(=O)C1COC(c2ccccc2O)=N1)C(=O)O[C@@H](C)CC(=O)NC1CCCCN(O)C1=O</smiles>

(4) Carboxylate Siderophores

Besides the hydroxamates, catecholates and mixed-ligand complexes, a new class of siderophores was isolated from various yeasts. These siderophores contain only aliphatic amines and /or carboxylate and hydroxyl donor groups as chelating ligands (Carrano, 1996). Rhizobactin DM4 (rhizoferrin, Figure 25) is the first representative of the carboxylate class of these siderophores and was originally isolated from Rhizopus 
microsporus by Neiland and his coworkers in 1985 (Smith, 1985). Rhizoferrin strongly binds and transports iron into the cell as do other siderophores; however, the coordination chemistry of the rhizoferrin iron complex is not well understood. The detailed mechanism of rhizoferrin-mediated transport by microorganisms is also under study (Carrano, 1996; Thiken, 1992).

Figure 25 Structure of rhizoferrin<smiles>O=C([O-])CC(O)(CC(=O)[O-])C[C@](O)(CC(=O)[O-])CC(=O)NCCCCNC(=O)[O-]</smiles>

(5) Peptide Siderophores

By reviewing the diverse structure of siderophores, we can find that many of them contain peptidic building blocks and some siderophores contain oligopeptides. The peptide side chains are available for complexation to ferric ions, such as the aforementioned pyoverdins. Among the amino acids attached to the chromophore, $\mathrm{N}^{5}$ acetyl- $\mathrm{N}^{5}$-hydroxy-ornithine and threo- $\beta$-aspartic acid provide the second and third bidentate iron chelating sites besides the catecholate. Among the siderophores with sidechain-connected amino acids along their backbone, coprogens have the diketopiperazine ring of two $\mathrm{N}^{5}$-acylated- $\mathrm{N}^{5}$-hydroxylated ornithine as the basic structure (Figure 26) (Drechsel and Jung, 1998). 
Figure 26 Structure of coprogen

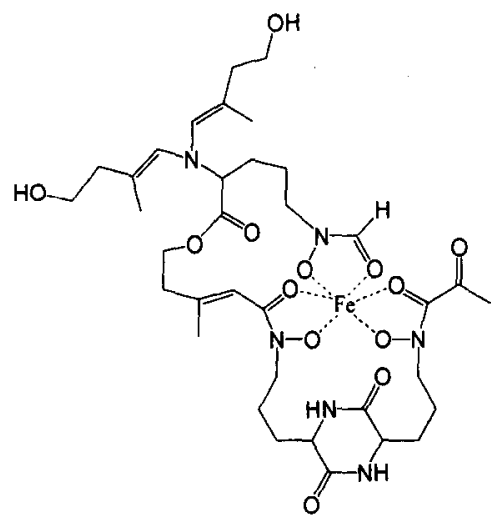

Enterobactin is a trimer of 2,3-dihydroxybenzoyl-L-serine (Figure 22), which complexes ferric ion as a hexadentate ligand. For the free ligand, by using three internal H-bonds of the amide protons to the lactone oxygen of the same serine, a cavity for complexing ferric ions is preformed. When ligand binding to ferric ions occurs, the $\mathrm{H}$ bonds are shifted to the catecholate oxygens (ortho position) (Shanzer and Libman, 1991).

Cyclized amino acids were also observed in siderophore structures. A 5methyloxazoline ring was found to be the common linker between hydroxylbenzoic acid and the dialkyl imide backbone in agrobactin (Figure 27), parabactin and fluvabactin. All of these siderophores have cyclized L-threonine, and some of those compounds have tricatecholate groups. For the non tricatecholate system, such as parabactin, the oxazoline nitrogen would also be involved in iron chelating as well as L-threonine. 
Figure 27 Ligand site of agrobactin $(\mathrm{R}=\mathrm{OH})$, parabactin $(\mathrm{R}=\mathrm{H})$ and fluvabactin $(\mathrm{R}=\mathrm{OH})$

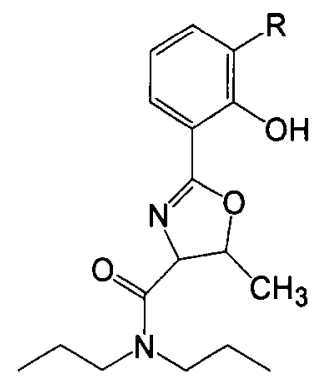

\section{Siderophore Detection}

Iron chelating capability can be proven by physiochemical means. When transition metals form complexes, charge transfer bands usually occur which give the complexes visible color. In the case of ferric complexes, charge transfer bands are seen between 350 and $650 \mathrm{~nm}$. These complexes can be visually detected as yellow-brown to red-brown compounds. In the classic $\mathrm{FeCl}_{3}$ test, the color of the solution changes from yellow to dark red once the hydroxamate iron complex is formed.

The chrome azurol sufonate assay has also been widely used for siderophore detection, because this test is comprehensive, exceptionally responsive and convenient. The chrome azurol sulfonate assay can be applied on agar surfaces or in solution. The assay is based on the color change that accompanies transfer of the ferric ion from an initial intense blue complex to the siderophore (Neilands, 1995).

\section{$4 \quad$ Methods for Metal Binding Assay}

Metal affinity chromatography was developed by Belfrage's group as a new approach for protein fractionation. This technique is based on the ability of proteins to bind metal ions immobilized on chelate gels (Porath, 1975). Volz and his coworkers 
successfully applied this technology in investigating the metal selectivity of $\mathrm{HxH}$ and CxxC polypeptides. Nitrotriacetic acid (NTA) agarose was preloaded with various metal chlorides and packed into a column before the column was connected to a protein liquid chromatography system. The polypeptide was applied to the NTA columns and the elution fractions were analyzed by sodium dodecylsulfate-polyacrylamide gel electrophoresis (SDS-PAGE) to detect metal binding peptides (Volz, 1998). Also quantitative metal ion affinity chromatography can be used to determine peptide-metal ion interaction stoichiometry.

(1) Electrospray Ionization- Mass Spectrometry (ESI-MS)

ESI mass spectrometry has been shown to be a powerful method for the characterization of non-covalent complexes of biomacromolecules (Przybylski, 1996). The gentleness of electrospray ionization allowed detection of very weakly associated complexes under the proper experimental conditions (Brewer, 2000). Once several parameters including $\mathrm{pH}$, ionic strength, temperature and source voltage parameters were carefully controlled, the ionization and volatilization process of ESI-MS did not lead to complex decomposition. As a result, ESI-MS has been used to characterize non-covalent complexes by Dorsselaer and his coworkers (Jaquinod, 1993). The affinity of metal ions to peptide sequences could be found by observing molecular mass ions, and the selectivity of peptide to metals was determined by measuring the abundance of molecular ions. (Przybylski, 1996) 
(2) Tandem Mass Spectrometry (MS/MS)

Tandem mass spectrometry (MS/MS) is a technique in which a precursor ion is isolated, which then undergoes a fragmentation to yield product ions and neutral fragments:

$$
\mathrm{m}_{\mathrm{p}}^{+} \longrightarrow \mathrm{m}_{\mathrm{d}}^{+}+\mathrm{m}_{\mathrm{n}}
$$

In the technique of MS/MS one mass spectrometer is coupled to a second spectrometer. The molecular ions are isolated by the first mass spectrometer from a sample mixture. Parent ions are then subjected to a second fragmentation to form a multitude of daughter ions and give a series of mass spectra, one for each molecular ion produced in the first spectrometer. The spectrum of these daughter ions is then scanned by the second spectrometer. One such instrument uses three quadrupoles, the first and the third of these function as spectrometers. The central one acts as an inert gas collision cell (CC) made up of a quadrupole using radio frequency (RF) only as a means of ion focusing. Besides the fragment (daughter)-ion MS/MS, the precursor (parent)-ion MS/MS is also utilized in tracking the parent peaks of the known fragment peak. In this technique the first spectrometer is scanned while the second spectrometer is set to the mass of one of the daughter ions.

Multistep tandem mass spectrometry $\left(\mathrm{MS}^{\mathrm{n}}\right)$ has been widely used in metal binding ligand characterization. Gross and Ngoka have successfully defined the metal binding sites on cyclic peptides by using MS/MS (Ngoka, 2000). The metal-containing cyclic peptide was subjected to multiple stages of collisionally activated decomposition (CAD) in an ion trap mass spectrometer. Upon collisional activation one amide bond was 
cleaved and the metal ion acted as a fixed charge site to direct a charge-remote, sequencespecific fragmentation of the ring-opened peptide.

(3) Matrix Assisted Laser Desorption Ionization - Time of Flight Mass Spectrometry (MALDI-TOF MS)

MALDI mass spectrometry is the offspring of the direct laser desorption (LD) mass spectrometry of small molecules and was first described by Karas and Hillenkamp in 1988 (Karas, 1988). This technique has become one of the most successful methods for the identification of various biologically active substances including proteins (Karas, 1989), oligosaccarides (Stahl, 1991), oligonucleotides (Overberg, 1992) and polymers (Baht, 1992). MALDI-MS is highly sensitive, and requires only femtomoles of sample. Mass accuracy is of $0.1-0.2 \%$ and can be improved to the level of $0.01 \%$ with the use of internal calibrants (Cohen, 1996). Theoretically it can analyze unlimited mass range, up to $10^{6}$ daltons $(\mathrm{Da})$. From a single ionization event, a complete set of mass spectra can be obtained, and substances can be identified from mixtures without previous fractionation.

MALDI-TOF MS is extensively used in qualitative analysis; however, the quantitation of proteins and peptides by this method is still very difficult. Significant variations in the ion signals obtained from consecutive laser shots, as well as from different spots in a given sample, complicate the direct quantification of analytes. These variations are due to non-homogeneous co-crystallization of matrix and sample molecules, fluctuations in laser power, and changes in detector response. The absolute intensities of the detected ions also depend on their chemical nature, although some suppression effects have been described (Beavis, 1990). All of these bring difficulties to quantitative analysis of proteins and peptides by MALDI-TOF MS. Internal standards 
have been used in the quantitation step to help overcome these problems. Jespersen found a linear correlation between the peak height ratio and the sample loading when similar proteins or peptides were used as internal standards. To maintain the accuracy for quantitation, the analyte and internal standard need to have the same chemical properties (Jespersen, 1995). The Mirgorodskaya group introduced stabilized ${ }^{18} \mathrm{O}$-labeled internal standards for the quantitative analysis of proteins and peptides by hydrolyzing proteins or peptides in ${ }^{18} \mathrm{O}$-water (Mirgorodskaya, 2000). Then an ${ }^{18} \mathrm{O}$-labeled standard was mixed with the corresponding unlabeled substance of unknown concentration. The isotopic pattern of the mixture could reflect the relative concentration of unlabeled compound and labeled standard (Mirgorodskaya, 2000).

A commonly used alternative quantitative method is normalization. This approach does not require the use of internal standards and is much simpler. Blair and his coworkers used the correction factor to normalize the peak intensity and enable MALDITOF MS to evaluate the binding selectivity of hosts. The binding selectivity was reflected in the intensities of the complexes after a correction factor of 1.4 was normalized to the intensity of every peak (Blair, 1998). The metal selectivity ratio obtained from the MALDI measurements agreed with the ratios obtained from comparable ESI experiments (Goolsby, 1999). However, this normalization method assumed that each sample component gave rise to a peak in the spectrum and the detector response was equivalent for all compounds. 


\section{B. Research Objectives}

Earlier work in our lab demonstrated that a cyclic heptapeptide with a dipeptide tail is a particularly effective host for a $\mathrm{Ca}^{2+}$ ion. A three-component, cyclohexapeptide mixture did not show any significant difference with respect to binding metal ions. This result also demonstrated that preferential binding of metal ions for a certain ligand could be detected by using a mixture of metal ions via competition FAB-MS studies (Chen, 1996).

This current work focused on the preparation of specific linear symmetric hexpeptides as selective siderophore analogues. Chiral amino acids were utilized to fix the stereochemistry of the side chains in well-defined and known positions, and the ligand binding sites were introduced into peptides by incorporating amino acids with metal binding side chains (glutamic acid or hydroxamate glutamic acid). Our approach used mass spectrometry as a semi-quantitative method to evaluate the metal binding abilities of peptide ligands and used an MS/MS technique to explore ligand metal binding modes. Relative peak abundances of peptide-metal ion adducts compared to free peptides were used as qualitative evidence for binding preference of the metal ions.

\section{Results and Discussion}

\section{Peptide Synthesis}

Siderophore analogues, linear hexapeptide $\mathrm{E}$ and peptide $\mathrm{H}$, containing amino acids with negatively charged side chains were designed and synthesized to explore metal binding capability and metal binding selectivity of these peptides. 
The target sequences were peptide $\mathrm{E}$ with the structure of Ac-Gly $1-\mathrm{Glu}_{2}-\mathrm{D}-\mathrm{Pro}_{3}-$ $\mathrm{Gly}_{4}-\mathrm{Glu}_{5}$-D-Pro $6-\mathrm{NH}_{2}$ and peptide $\mathrm{H}$ with the structure of $\mathrm{Ac}-\mathrm{Gly}_{1}-\mathrm{Glu}_{2}(\mathrm{NHOH})-\mathrm{D}$ $\mathrm{Pro}_{3}-\mathrm{Gly}_{4}-\mathrm{Glu}_{5}(\mathrm{NHOH})-\mathrm{D}-\mathrm{Pro}_{6}-\mathrm{NH}_{2}$ (Figure 28). These peptides were composed of the amino acids in a repetitive sequence to provide some symmetry to the peptide chain, because symmetric structures are commonly observed in natural ionophores. Two proline residues were incorporated to induce turn conformations, which are also a common structural feature of many natural ionophores. The potential metal binding sites were provided by amino acids with carboxylate groups and hydroxamate group side chains in both peptides. In peptide E, two carboxylic acid groups on the glutamic side chains can function as metal chelators after being deprotonated. In peptide $\mathrm{H}$, the strong metal chelator, the hydroxamic acid group, was substituted for each of the carboxylic acids on the glutamic acid side chains to determine whether the introduction of a hydroxamic acid residue would change the peptide metal binding capability and metal selectivity. The metal binding selectivity was tested by mass spectrometry and metal binding modes were explored by using MS/MS.

Peptide E (Ac-Gly 1 -Glu 2 -D-Pro - Gly $\left._{4}-\mathrm{Glu}_{5}-\mathrm{D}-\mathrm{Pro}_{6}-\mathrm{NH}_{2}\right)$

Peptide E was prepared by using Boc chemistry in solid phase peptide synthesis. To obtain a C-terminal amidated peptide, the peptide chain was built on a $p \mathrm{MBHA}$ resin, and the amino acid building blocks used were Boc-D-Pro-OH, Boc-Glu(OBn)-OH and Boc-Gly-OH. HF was used to cleave the peptide from the resin after peptide chain elongation and $\mathrm{N}$ terminal acetylation. The peptide was purified by eluting through a $\mathrm{C} 18$ reverse phase column with water/ acetonitrile solvent. 
Peptide H (Ac-Gly $\left.1-\mathrm{Glu}_{2}(\mathrm{NHOH})-\mathrm{D}-\mathrm{Pro}_{3}-\mathrm{Gly}_{4}-\mathrm{Glu}_{5}(\mathrm{NHOH})-\mathrm{D}-\mathrm{Pro}_{6}-\mathrm{NH}_{2}\right)$

Peptide $\mathrm{H}$ (dihydroxamate peptide) was synthesized by following the hydroxamic acid peptide solid phase synthesis method (Figure 29) discussed in Chapter 1. Fmoc chemistry was used to build the peptide chain followed by prolonged TFA treatment to deprotect the $\mathrm{O}^{t} \mathrm{Bu}$ protecting group on glutamic acid. The unprotected carbonyl group was then available for further modification. $\mathrm{BnONH}_{2} \cdot \mathrm{HCl}$ was condensed with $\mathrm{BOP}$ and DIEA, which resulted in Ac-Gly-Glu(NHOBn)-D-Pro-Gly-Glu(NHOBn)-D-Pro-resin, and the Bn group was simultaneously removed when the peptide was cleaved from the resin by $\mathrm{HF}$.

Figure 28 Structure of peptide $\mathrm{E}$ and peptide $\mathrm{H}$

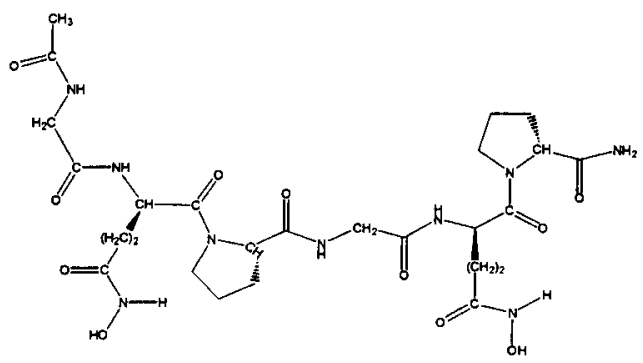

Peptide H

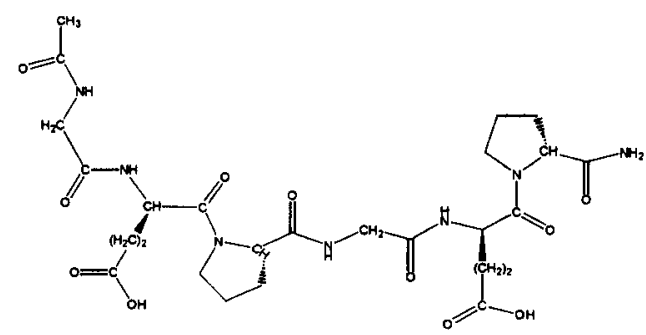

Peptide E 
Figure 29 Solid phase synthesis of peptide $\mathrm{H}$

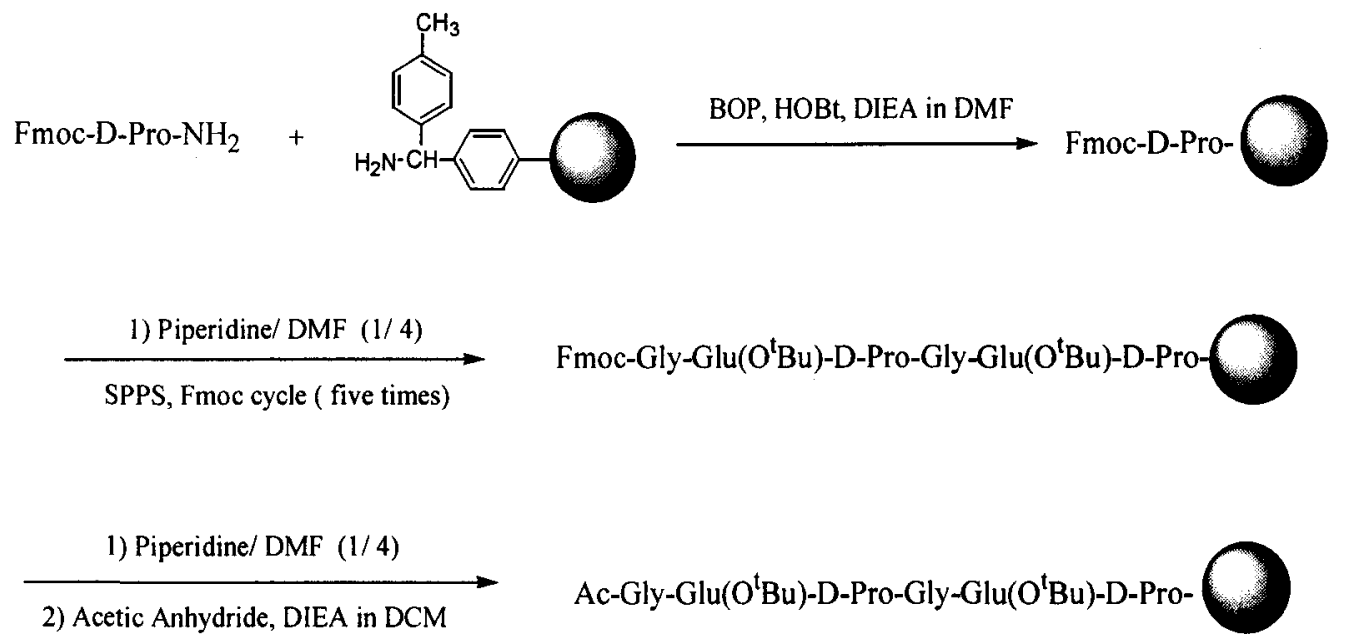

1) TFA/ DCM/Anisole (70/25/5), $3 \times 30 \mathrm{~min}$

2) $10 \%$ DIEA in DMF

Ac-Gly-Glu(NHOBn)-D-Pro-Gly-Glu(NHOBn)-D-Pro-

3) $\mathrm{NH}_{2} \mathrm{OBn}, \mathrm{BOP}, \mathrm{HOBt}, \mathrm{DIEA}$ in DMF

$\stackrel{\mathrm{HF}, \text { anisole }}{\longrightarrow} \quad$ Ac-Gly-Glu(NHOH)-D-Pro-Gly-Glu(NHOH)-D-Pro-NH${ }_{2}$

\section{Metal Binding Studies with Peptide E (Ac-Gly -Glu $_{2}$-D-Pro $\mathbf{3}^{-}-\mathrm{Gly}_{4}$ -}

\section{Glu $_{5}-\mathrm{D}-\mathrm{Pro}_{6}-\mathrm{NH}_{2}$ ) with MALDI-TOF MS}

In the following mass spectrometry study, "L" was used to stand for free peptide E molecule. First, the free ligand peptide E was subjected to MALDI-MS. A [L $+\mathrm{H}]^{+}$ $(\mathrm{m} / \mathrm{z}=625)$ molecular ion peak was not detected in spectrum (Figure $30 \mathrm{~d})$; instead $[\mathrm{L}+$ $\mathrm{Na}^{+}$and $[\mathrm{L}+\mathrm{K}]^{+}$ions were the prominent peaks at $\mathrm{m} / \mathrm{z} 648$ and 664 , respectively, indicating the samples were possibly contaminated by the alkali metals from glass surfaces. When we ran the same sample on an ESI-MS instrument, the $[\mathrm{L}+\mathrm{H}]^{+}$peak was clearly observed and peptide adducts with sodium and potassium were much less significant (Figure 32). In this case, ESI-MS appears to be a more appropriate instrument 
than MALDI-MS, because ESI-MS allows the detection of free ligand without capture of alkali metal ions from the environment.

In the evaluation of peptide $\mathrm{E}$ metal binding capability, peptide $\mathrm{E}$ was combined with single metal ions by mixing equimolar quantities of metal perchlorate salt $\left(\mathrm{Ni}\left(\mathrm{ClO}_{4}\right)_{2}, \mathrm{Zn}\left(\mathrm{ClO}_{4}\right)_{2}\right.$ or $\left.\mathrm{Fe}\left(\mathrm{ClO}_{4}\right)_{3}\right)$ and free peptide $\mathrm{E}$ in water $\left(0.6 \mu \mathrm{mol}\right.$ in $\left.50 \mu \mathrm{L} \mathrm{H} \mathrm{H}_{2} \mathrm{O}\right)$. Each complex sample was combined with an excess of $\alpha$-cyano-4-hydroxycinnamic acid matrix in a water $(0.1 \% \mathrm{TFA})$ / acetonitrile $(1: 2)$ solution and allowed to air dry before being tested by the MALDI-TOF MS.

Figure 31 (spectra A-C) illustrates the MALDI-MS data of peptide E binding a single metal ion $\left(\mathrm{Ni}^{2+}, \mathrm{Zn}^{2+}\right.$ and $\mathrm{Fe}^{3+}$ respectively). The expected ligand metal complex species $\left[\mathrm{L}+\mathrm{Ni}^{2+}-\mathrm{H}^{+}\right]^{+},\left[\mathrm{L}+\mathrm{Zn}^{2+}-\mathrm{H}^{+}\right]^{+}$or $\left[\mathrm{L}+\mathrm{Fe}^{3+}-2 \mathrm{H}^{+}\right]^{+}$was observed in respective experiments, and $[\mathrm{L}+\mathrm{Na}]^{+}$and $[\mathrm{L}+\mathrm{K}]^{+}$ions were also detected in each mass spectrum. Figure 30 shows the proposed peptide $\mathrm{E}$ metal binding modes to $\mathrm{Ni}^{2+}, \mathrm{Zn}^{2+}$ and $\mathrm{Fe}^{3+}$. Since both $\mathrm{Ni}(\mathrm{II})$ and $\mathrm{Zn}(\mathrm{II})$ are doubly charged ions and bind the metal in a similar fashion (Figure 30), then the two Glu anions neutralize divalent metals and therefore the complex requires additional protonation for the ligand. However, this is no longer the case with $\mathrm{Fe}^{3+}$ and the masses observed agree with this interpretation.

Figure 30 Metal binding modes of peptide $\mathrm{E}$ with $\mathrm{M}^{2+}\left(\mathrm{Zn}^{2+}\right.$ or $\left.\mathrm{Ni}^{2+}\right)$ and $\mathrm{Fe}^{3+}$

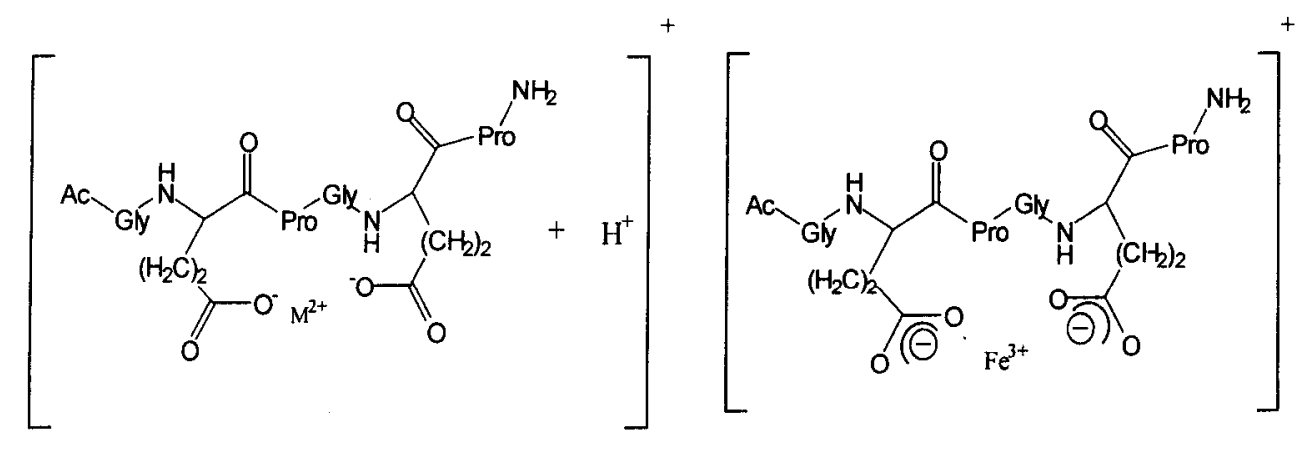


Figure 31 MALDI-MS studies of peptide E (L) (Ac-Gly-Glu-D-Pro-Gly-Glu-D-Pro-NH2 $)(31 \mathrm{~d})$ and peptide E (MW=625) with single metal ion (31a: peptide $\mathrm{E} \cdot \mathrm{Zn}^{2+}, 31 \mathrm{~b}$ : peptide $\mathrm{E} \cdot \mathrm{Ni}^{2+}, 31 \mathrm{c}$ : peptide $\mathrm{E} \cdot \mathrm{Fe}^{3+}$ )

$\mathbf{a}$

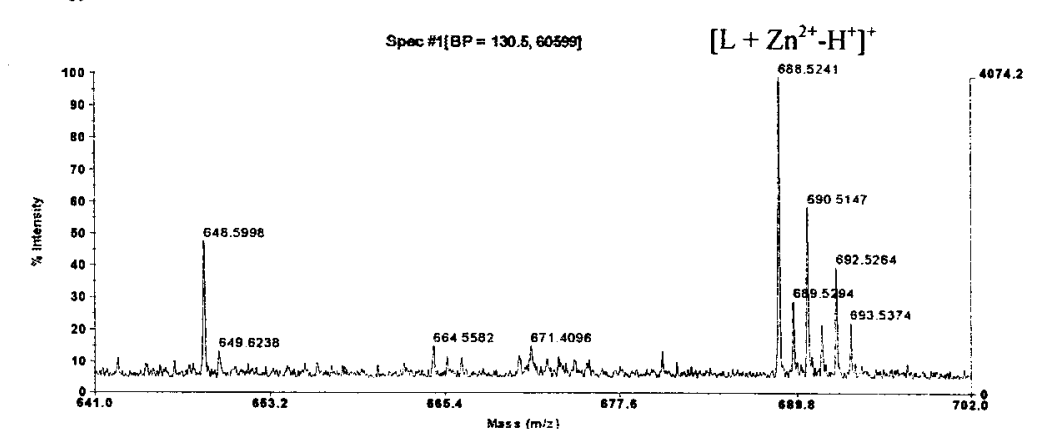

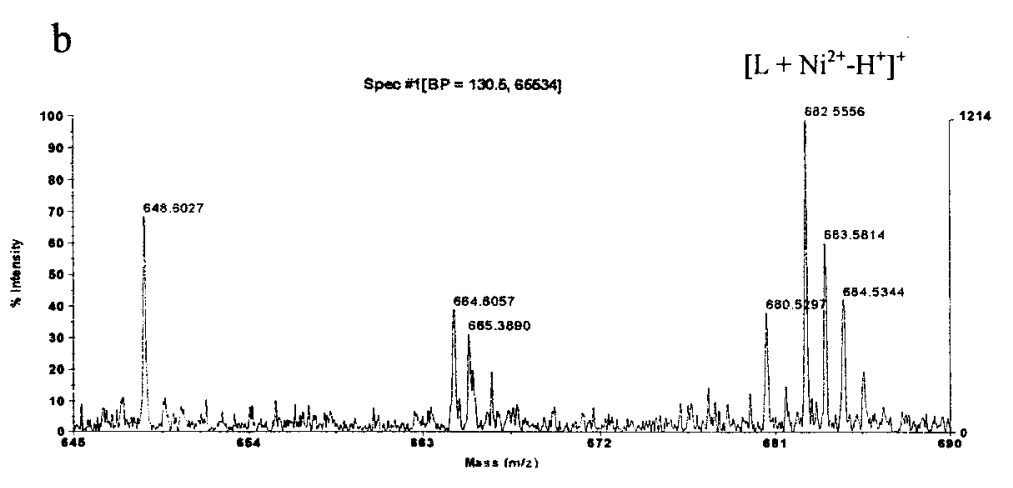

c

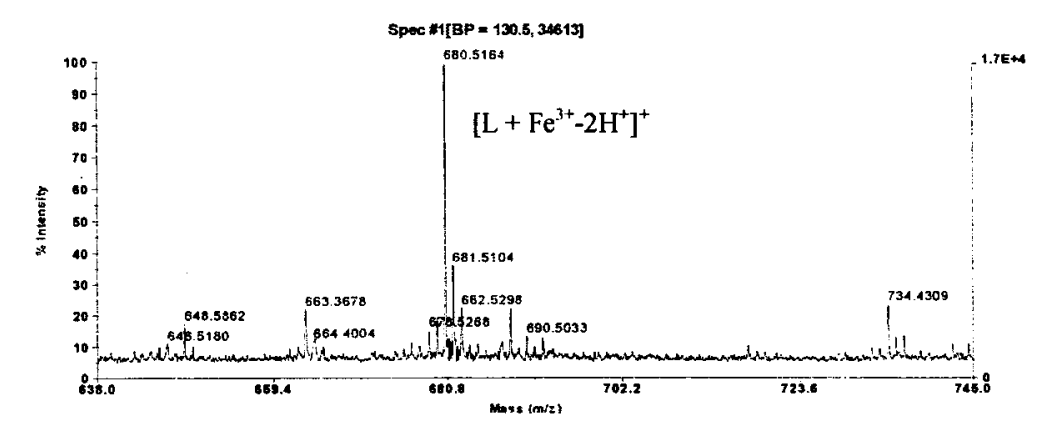

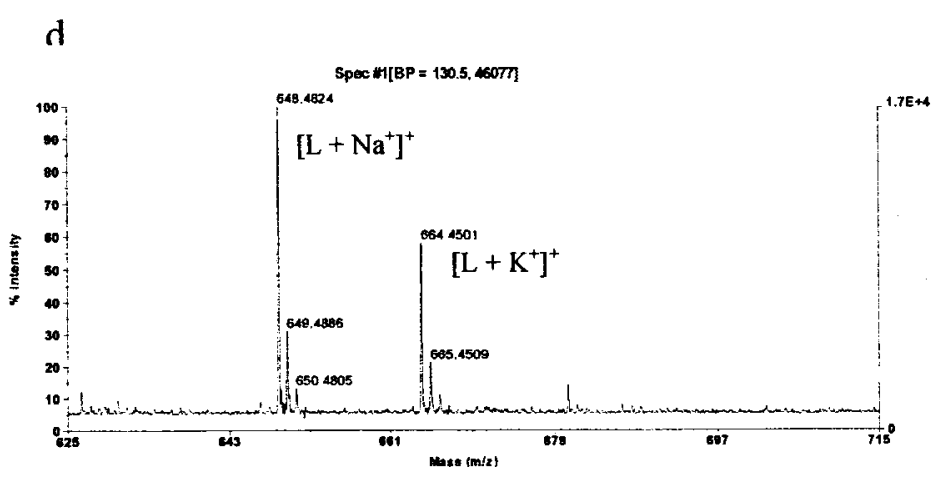




\section{$\mathrm{NH}_{2}$ ) Using ESI-MS}

As mentioned before, the free ligand peptide $\mathrm{E}$ molecular ion $[\mathrm{L}+\mathrm{H}]^{+}$ion was clearly observed in the ESI-MS spectrum, and $[\mathrm{L}+\mathrm{Na}]^{+}$and $[\mathrm{L}+\mathrm{K}]^{+}$peaks were almost undetectable (Figure 32).

Figure 32 ESI-MS spectrum of peptide E

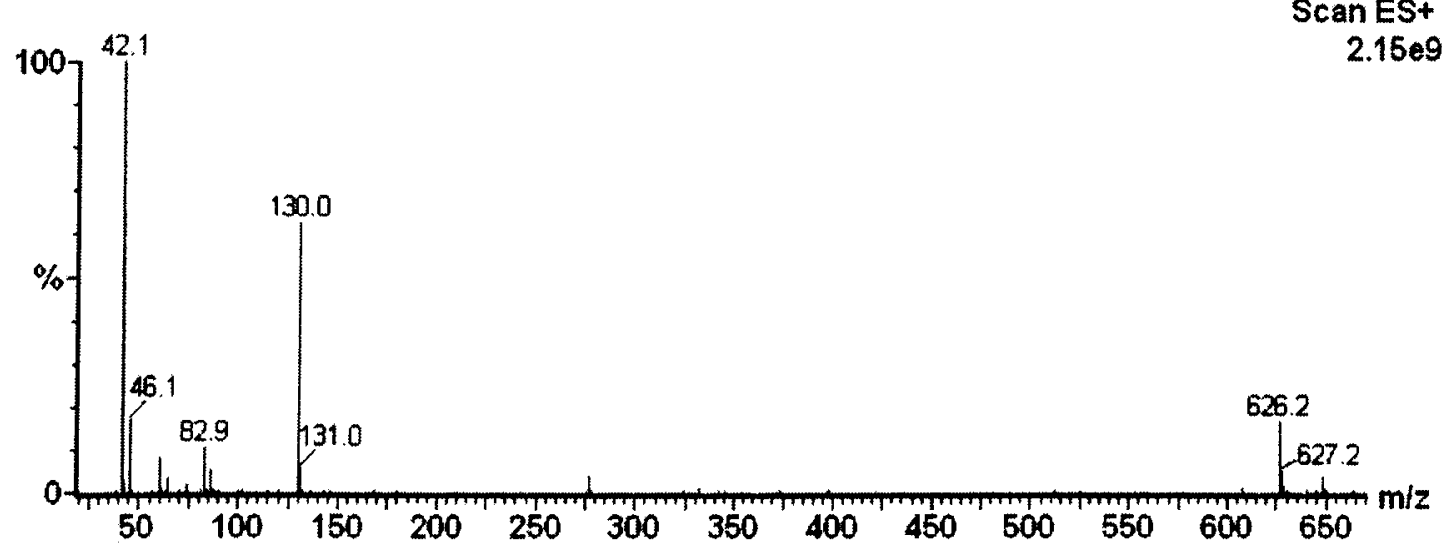

(1) Peptide E Binding with Single Metal Studies

In our peptide metal complex experiment, equimolar amounts of metal perchlorate salt and peptide $E$ were dissolved in a 1:1 water-acetonitrile solution. In a subsequent peptide metal binding competitive experiment, metal perchlorate salt mixtures were prepared with different ratios, which were dissolved in 1:1 water-acetonitrile solution, followed by the introduction of peptide $\mathrm{E}$ with the desired concentration into the solution. To achieve good ionization under the electrospray, formic acid was also added to each sample to adjust $\mathrm{pH}$ to 5 before being subjected to ESI-MS, therefore assuming partial protonation of glutamyl side chains. The peak abundances of the free ligand ion and ligand-metal adduct ions were recorded. The relative stability of the ligand-metal 
adducts was evaluated by relative peak abundance (RPA), which is defined in this case as the ratio of peptide-metal complex peak height to free peptide peak height. Peptide $\mathrm{E}$ single metal complex results are summarized in Table 8, while Table 9 contains the results of the peptide $\mathrm{E}$ competitive metal binding studies. Although the RPA value cannot be considered in any way a quantitative measure of metal ion binding, this value could be used as a semi-quantitative index to probe the most predominant species among the complex mixtures in one experiment.

Figure $38 \mathrm{~b}, 40 \mathrm{~b}$ and $42 \mathrm{~b}$ illustrate ESI-MS data of peptide $\mathrm{H} \cdot \mathrm{Ni}(\mathrm{II})$, peptide $\mathrm{H} \cdot$ $\mathrm{Zn}(\mathrm{II})$ and peptide $\mathrm{H} \cdot \mathrm{Fe}(\mathrm{III})$ respectively, which are largely different from the MALDIMS experiment of the same species. Although we did observe the expected peaks for [ $\mathrm{L}+$ $\left.\mathrm{Ni}^{2+}-\mathrm{H}^{+}\right]^{+}$at $682,\left[\mathrm{~L}+\mathrm{Zn}^{2+}-\mathrm{H}^{+}\right]^{+}$at 688 and $\left[\mathrm{L}+\mathrm{Fe}^{3+}-2 \mathrm{H}^{+}\right]^{+}$at 679 in their respective experiments, which were also found in earlier MALDI-MS experiments (Figure 31a-c), all these peaks were in much lower intensity compared to the peaks of $\left[\mathrm{L}+\mathrm{Ni}^{2+}\right]^{2+}$ at 342 , $\left[\mathrm{L}+\mathrm{Zn}^{2+}\right]^{2+}$ at 345 and $\left[\mathrm{L}+\mathrm{Fe}^{3+}-\mathrm{H}\right]^{2+}$ at 340 in single metal ligand complex ESI-MS study. Summarized in Table 8, the RPA values of the doubly charged ions peaks were several hundred times larger than the RPA of singly charged adducts, which demonstrates that the doubly charged complex ions were the most abundant species in ESI mass spectra. This unique phenomenon was only observed in the ESI-MS study and did not occur in MALDI-MS study. A possible explanation could be that these doubly charged species arose during the ionization process, from the electro sprayed droplets, where evaporation would presumably lead to higher concentrations and alter solution conditions. Singly charged complex molecules obtained one more proton and were shown as the divalent charged species in ESI-MS. 
For peptide $\mathrm{E} \cdot \mathrm{Ni}^{2+}$ and peptide $\mathrm{E} \cdot \mathrm{Zn}^{2+}$ complexes, a perchlorate ion adduct was also observed (Figure $39 \mathrm{~d}$ and Figure $41 \mathrm{c}$ ). In the complex of peptide $\mathrm{E}$ binding nickel, a doubly charged peptide-metal-peptide sandwich complex with a mass of $1308.8(\mathrm{~m} / \mathrm{z}=$ 654.4) was detected (Figure $38 \mathrm{~b}$ and $39 \mathrm{~d}$ ).

Comparing the results of MALDI-MS and ESI-MS, we found that ESI-MS is a better tool to study the non-covalent complex, which was also proved by Pramanik group who utilized ESI-MS for the study of non-covalent protein-metal complex [HCV (1-181)Zn] (Pramanik, 1998). Using ESI-MS allowed us to study metal-protein interactions in solution, since in a metal ligand complex system, pre-existing ions in solution could be observed directly as a consequence of the soft transfer to the gas phase. Although MALDI-MS has been recognized as an effective method in intact peptide/ protein detection, the ambiguity of adduct attachment of ligand and metal determined the disadvantage of MALDI-MS in metal ligand complex study.

\section{(2) Peptide E Ligand Competitive Metal Binding Studies}

In competitive metal binding studies, the doubly charged metal ligand adducts are still the predominant forms in metal peptide complexes, which is in agreement of single metal binding test, although the peaks were presented in relative low resolution (Figure $43 \mathrm{a}$ and $43 \mathrm{e})$. Therefore we used relative peak abundances of $[\mathrm{L}+\mathrm{M}]^{2+}(\mathrm{M}: \mathrm{Ni}$ or $\mathrm{Zn})$ (adduct peak intensity $v s$ free peptide peak intensity) to evaluate the metal affinities to the peptide (Table 9) (Figure 43e). Peptide E contains a carboxylate side chain and has the metal binding potential to some degree, which is shown in MS study; however, the metal preference is not obvious, and the slight selectivity of the peptide $E$ for metal ions was found to be $\mathrm{Ni}^{2+}>\mathrm{Zn}^{2+}>\mathrm{Fe}^{3+}$. 
Table 8 Peptide Ac-Gly-Glu-D-Pro-Gly-Glu-D-Pro- $\mathrm{NH}_{2}$ (L) metal binding assay in individual tests by ESI-MS

\begin{tabular}{cccc}
\hline $\begin{array}{c}\text { Peptide metal } \\
\text { ion complex }\end{array}$ & Peak found $(\mathrm{m} / \mathrm{z})$ & Adduct formation & $\begin{array}{c}\text { [Adduct }] /\left[\mathrm{m}+\mathrm{H}^{+}\right]^{+} \\
(\mathrm{RPA})\end{array}$ \\
\hline $\mathrm{L}+\mathrm{Fe}^{3+}$ & 679.4 & {$\left[\mathrm{~L}+\mathrm{Fe}^{3+}-2 \mathrm{H}^{+}\right]^{+}$} & 0.03 \\
& 340.3 & {$\left[\mathrm{~L}+\mathrm{Fe}^{3+}-\mathrm{H}^{+}\right]^{2+}$} & 4.03 \\
& 685.7 & Undetermined & 0.15 \\
\hline $\mathrm{L}+\mathrm{Zn}^{2+}$ & 688.4 & {$\left[\mathrm{~L}+\mathrm{Zn}^{2+}-\mathrm{H}^{+}\right]^{+}$} & 0.43 \\
& 344.7 & {$\left[\mathrm{~L}+\mathrm{Zn}^{2+}\right]^{2+}$} & 53.13 \\
& 788.3 & {$\left[\mathrm{~L}+\left(\mathrm{ZnClO}_{4}\right)^{+}\right]^{+}$} & 0.48 \\
& 657.4 & $\mathrm{Undetermined}$ & 0.48 \\
\hline & 682.4 & {$\left[\mathrm{~L}+\mathrm{Ni}^{2+}-\mathrm{H}^{+}\right]^{+}$} & 1.23 \\
& 341.8 & {$\left[\mathrm{~L}+\mathrm{Ni}^{2+}\right]^{2+}$} & 426.82 \\
& 654.4 & {$\left[\mathrm{~L}+\mathrm{Ni}^{2+}+\mathrm{L}^{2+}\right.$} & 7.41 \\
& 782.3 & {$\left[\mathrm{~L}+\left(\mathrm{NiClO}_{4}\right)^{+}\right]^{+}$} & 3.22 \\
\hline
\end{tabular}


Table 9 Using ESI-MS to assess peptide E (L) metal binding with a mixture of metal ions in competition experiment

\begin{tabular}{cccc}
\hline $\begin{array}{c}\text { Peptide metal } \\
\text { complex }\end{array}$ & Peak found $(\mathrm{m} / \mathrm{z})$ & Adduct formation & $\begin{array}{c}{[\text { Adduct }] /\left[\mathrm{L}+\mathrm{H}^{+}\right]^{+}} \\
(\mathrm{RPA})\end{array}$ \\
\hline $\mathrm{L}+\mathrm{Fe}^{3+}$ & 679.36 & {$\left[\mathrm{~L}+\mathrm{Fe}^{3+}-2 \mathrm{H}^{+}\right]^{+}$} & 0.05 \\
& 340.26 & {$\left[\mathrm{~L}+\mathrm{Fe}^{3+}-\mathrm{H}^{+}\right]^{2+}$} & 6.63 \\
& 685.69 & Undetermined & 0.10 \\
\hline $\mathrm{L}+\mathrm{Zn}^{2+}$ & 688.35 & {$\left[\mathrm{~L}+\mathrm{Zn}^{2+}-\mathrm{H}^{+}\right]^{+}$} & 0.06 \\
& 344.78 & {$\left[\mathrm{~L}+\mathrm{Zn}^{2+}\right]^{2+}$} & 9.54 \\
\hline $\mathrm{L}+\mathrm{Ni}^{2+}$ & 682.38 & {$\left[\mathrm{~L}+\mathrm{Ni}^{2+}-\mathrm{H}^{+}\right]^{+}$} & Undetectable \\
& 341.77 & {$\left[\mathrm{~L}+\mathrm{Ni}^{2+}\right]^{2+}$} & 12.06 \\
\hline
\end{tabular}

(3) Peptide E $\cdot$ Metal Ion Complexes Structures

In this study we also attempted to elucidate the geometry structures of peptide $\mathrm{E}$ metal complexes based on the obtained MS results and the known metal ion coordination characters. $\mathrm{A} \mathrm{d}^{8} \mathrm{Ni}^{\mathrm{Il}}$ ion can exist in six coordinate octahedral and four coordinate tetrahedral or square planar geometries depending on the ligand-field splitting of the center metal. The diamagnetic (low spin) Ni(II) would have a square-planar geometry, and both tetrahedral and octahedral $\mathrm{d}^{8} \mathrm{Ni}$ (II) complexes usually have two unpaired electrons and would be paramagnetic (high spin). Many nickel (II) complexes tend to form an equilibrium among several geometries. A famous example is the Lifschitz salt, nickel (II) complexes of substituted ethylenediamines. Depending on the temperature, solvent, anions present and other factors, this complex varies widely in color and 
magnetic properties. This phenomenon is the result of facile and reversible addition of ligands at the axial positions of square-planar complexes and changing $\mathrm{Ni}(\mathrm{II})$ from diamagnetic to paramagnetic.

Among the over two hundred known $\mathrm{Zn}^{2+}$ proteins, $\mathrm{Zn}^{2+}$ has the preference binding to histidine, cysteine and aspartic acid. In most cases, zinc forms fourcoordinated or six-coordinated complexes with ligands. The four-coordinated zinc complex prefers tetrahedral stereochemistry, and no square-planar complex has been observed. For example, zinc binds thermolysin by tetrahedrally coordinating three side chains, from two histidines, glutamic acid and a water molecule (Lippard and Berg, 1994).

Glutamic acids commonly function as ligands with common modes of interaction illustrated in Figure 33. Glutamic acid can function as a bridging ligand between two metal ions, serve as a terminal ligand to one or two ions, or act as a bidentate chelator to bind one metal ion. Besides the aforementioned $\mathrm{M}_{2} \mathrm{~L}$ and $\mathrm{ML}$ complexes, a $\mathrm{ML}_{2}$ complex could be formed by one metal coordinating two ligands.

Figure 33 Metal binding modes of carboxylate ligand<smiles>[M]OC(C)=O</smiles>

a<smiles>[M]OC(C)=O</smiles>

b<smiles>[M]OC(C)O[M]</smiles>

c<smiles>CC(=O)O[W]OC(C)=O</smiles>

d<smiles>[M]OC1OC1C</smiles>

e 
Since an ML complex is the most observed metal ligand adducts in our study (Table 8) and the chelator binding (Figure 33e) provides the most stable complex, we proposed that two glutamic side chains function as the tetradentate chelator in binding divalent nickel or zinc ion. Both $\mathrm{Ni}(\mathrm{II})$ and $\mathrm{Zn}(\mathrm{II})$ (referred as $\mathrm{M}(\mathrm{II})$ or $\mathrm{M}^{2+}$ ) are fourcoordinate metal ions and binding the tetradentate ligand would satisfy the coordination geometry. Center metal zinc should adopt a tetrahedral geometry, and nickel could be either square-planar or tetrahedral, as shown in Figure 34. The complex ions $\left[\mathrm{L}+\mathrm{M}^{2+}\right.$ $\left.\mathrm{H}^{+}\right]^{+}$and $\left[\mathrm{L}+\mathrm{M}^{2+}\right]^{2+}$ observed in the MS study are the same ligand-metal complex acquiring one or two protons from the environment. The observed peptide E $\cdot$ Nickel $\cdot$ peptide $\mathrm{E}$ sandwich complex $\left(\mathrm{NiL}_{2}{ }^{2+}\right)$ could be an equilibrated structure among four species as Figure 35 illustrates. In this case interligand metal binding is favored over intraligand binding and tetrahedral nickel binds with two chelators provided by different ligand molecules. Also, an alternative structure of the $\mathrm{NiL}_{2}{ }^{2+}$ complex is proposed in Figure 36. The octahedral nickel coordination sphere consists of two bidentate carboxylate chelator and two oxygen atoms from the remaining carboxylate groups. The definite metal binding mode of $\mathrm{NiL}_{2}{ }^{2+}$ complex was not determined in our study. 
Figure 34 Proposed structure of the peptide $\mathrm{E} \cdot$ metal $(\mathrm{ML})$ complexes $\left(\mathrm{M}: \mathrm{Ni}^{2+}\right.$ or $\mathrm{Zn}^{2+} ; \mathrm{L}:$ Ac-Gly-Glu- ${ }_{\mathrm{d}}$ Pro-Gly-Glu- ${ }_{\mathrm{d}}$ Pro--NH ${ }_{2}$ )

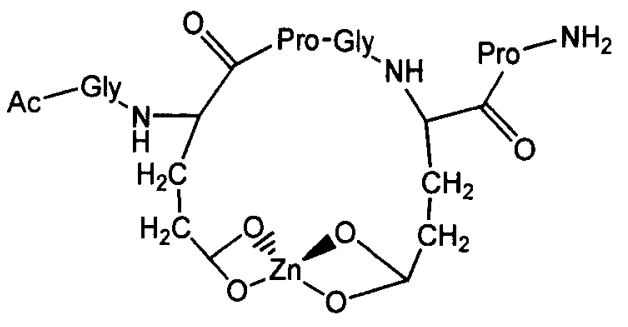

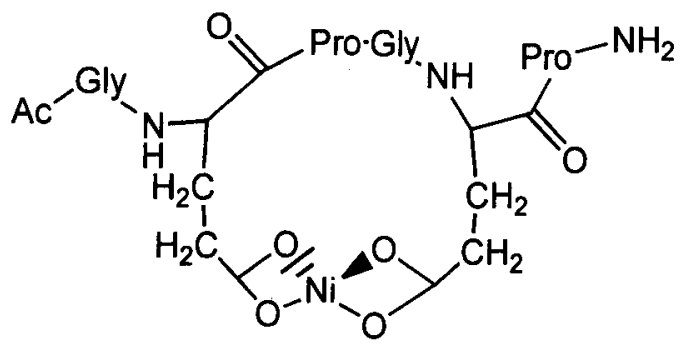

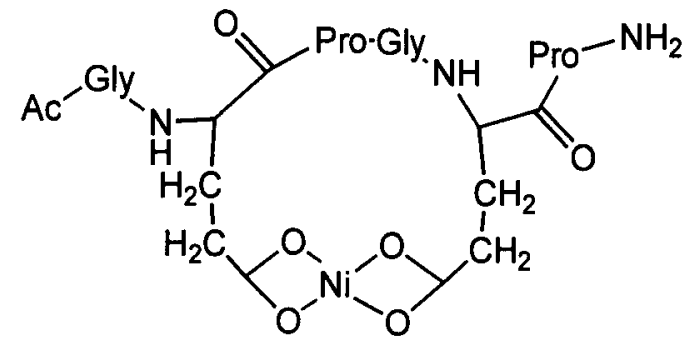

Figure 35 Proposed equilibrated structures of the sandwich complex peptide E $\cdot \mathrm{Ni}$. peptide $\mathrm{E}$ (Ni adopts the tetrahedral structure)
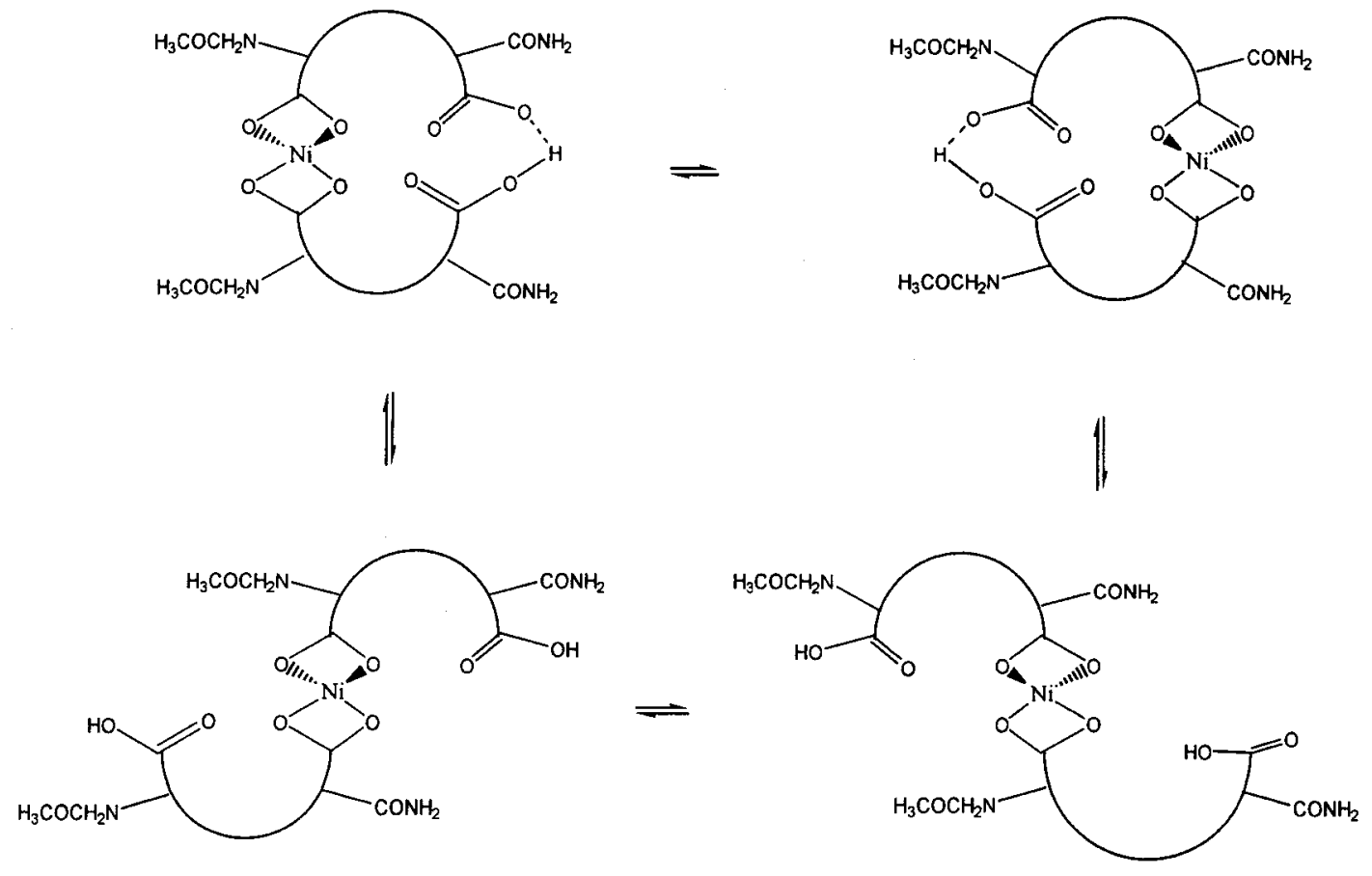
Figure 36 Alternative proposed structure of the sandwich complex peptide $\mathrm{E} \cdot \mathrm{Ni}$. peptide $\mathrm{E}$ (Ni adopts the octahedral structure)

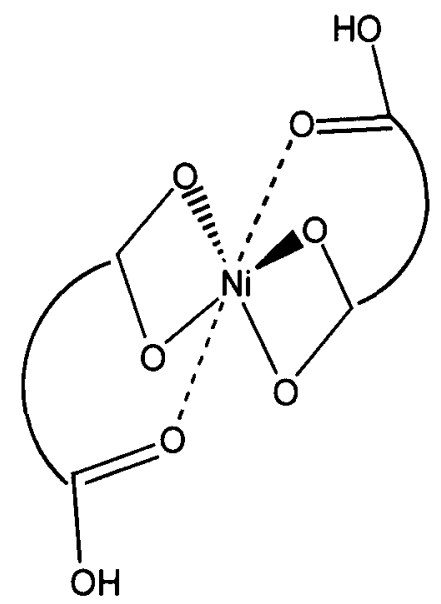

When $\mathrm{Fe}^{3+}$ binds with peptide $\mathrm{E}$ ligand, we observed both $\mathrm{Fe}(\mathrm{III}) \mathrm{H}_{-2} \mathrm{~L}^{+}$and $\mathrm{Fe}(\mathrm{III}) \mathrm{H}_{-1} \mathrm{~L}^{2+}$ complexes. Since iron always adopts a six-coordinated octahedral geometry, the iron could be coordinated by tetradentate dicarboxylic acid ligand and two water molecules to complete its six-coordination, and the proposed structure is shown in Figure 37.

Figure 37 Proposed coordination structure of the peptide $E \cdot F e(I I I)$ complex

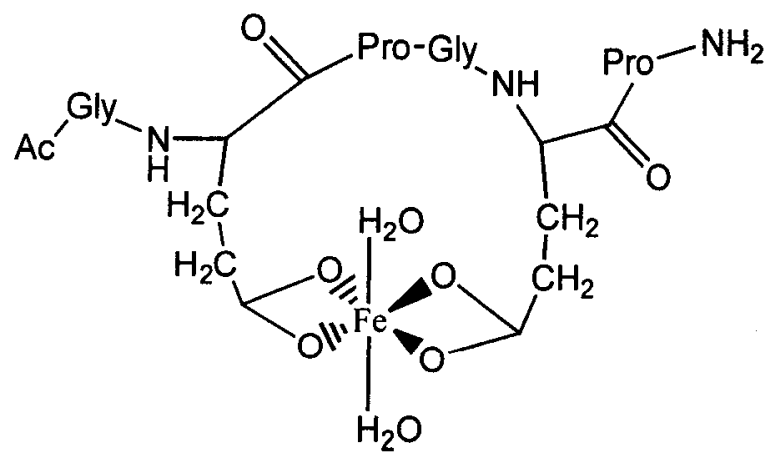


In summary, in the acidic water/ actonitrile (1:1) solution of peptide E metal perchlorate complexes $(\mathrm{pH}=5)$, doubly charged species $\mathrm{ML}^{2+}(\mathrm{M}: \mathrm{Ni}(\mathrm{II})$ and $\mathrm{Zn}(\mathrm{II}))$ existed as the predominant ligand metal adducts in the form of $\left[\mathrm{Ni}^{2+} \mathrm{L}\right]^{2+}(\mathrm{m} / \mathrm{z}=341.8)$ and $\left[\mathrm{Zn}^{2+} \mathrm{L}\right]^{2+}(\mathrm{m} / \mathrm{z}=344.7)$ based on ESI-MS data (Table 8, Figure 38-41). $\mathrm{MH}_{-1} \mathrm{~L}^{+}$ complexes were also observed in both peptide $\mathrm{E}$ nickel and zinc adducts as $\left[\mathrm{Ni}^{2+} \mathrm{L}-\mathrm{H}^{+}\right]^{+}$ $(\mathrm{m} / \mathrm{z}=682.4)$ and $\left[\mathrm{Zn}^{2+} \mathrm{L}-\mathrm{H}^{+}\right]^{+}(\mathrm{m} / \mathrm{z}=688.4) . \mathrm{ML}^{2+}$ complex could also be present in the form of perchlorate salts as $\left[\mathrm{Ni}^{2+} \mathrm{L}+\mathrm{ClO}_{4}\right]^{+}$ion $(\mathrm{m} / \mathrm{z}=782.4)$ and $\left[\mathrm{Zn}^{2+} \mathrm{L}+\mathrm{ClO}_{4}\right]^{+}$ $(\mathrm{m} / \mathrm{z}=788)$ (Figure 39,41). Other species of metal ligand complex could also exist in the system but were not observed in this study. Such unobserved complexes could remain uncharged and undetected in MS or the corresponding $\mathrm{m} / \mathrm{z}$ value could be out of the scanned range $(\mathrm{m} / \mathrm{z}=10-820)$. 
Figure 38 ESI-MS study of the peptide $\mathrm{E}(\mathrm{L}) \mathrm{Ni}^{2+}$ complex

(38a (top) Calculated spectrum for $\mathrm{C}_{26} \mathrm{H}_{37} \mathrm{~N}_{7} \mathrm{O}_{11} \mathrm{Ni} ; 38 \mathrm{~b}$ (bottom) Experimental spectrum showing small peaks at 682 (nickel complex) and peaks at 654 (a proposed species peptide-nickel-peptide sandwich complex) amplified fifty times. $(\mathrm{Ni}: \mathrm{m} / \mathrm{z}=58)$ )

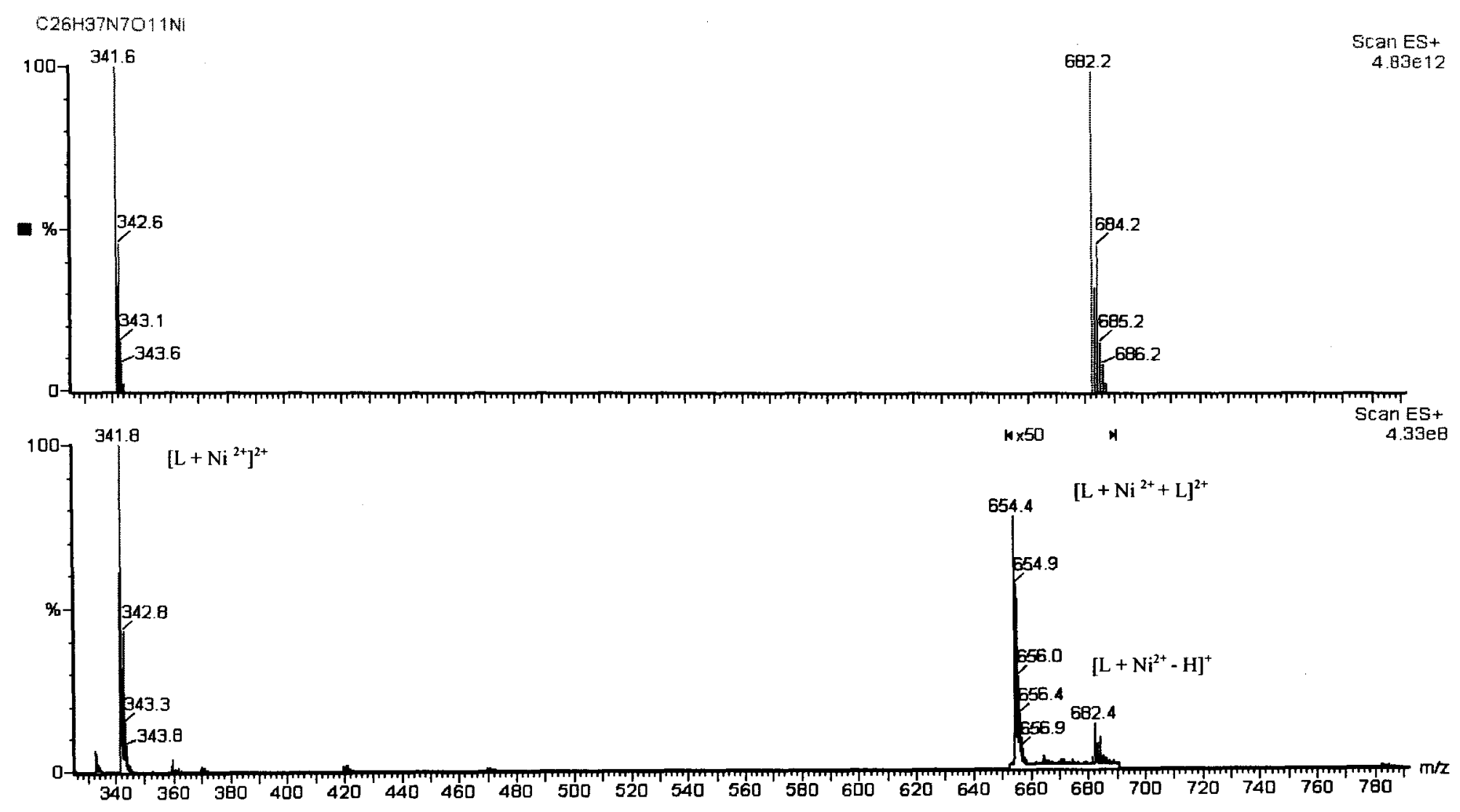


Figure 39 ESI-MS study of the peptide $\mathrm{E}(\mathrm{L}) \cdot \mathrm{Ni}^{2+}$ complex (higher mass region)

(39a: Calculated spectrum for $\mathrm{C}_{52} \mathrm{H}_{78} \mathrm{~N}_{14} \mathrm{O}_{22} \mathrm{Ni}$; 39b: Calculated spectrum for $\mathrm{C}_{26} \mathrm{H}_{37} \mathrm{~N}_{7} \mathrm{O}_{11} \mathrm{Ni}$;

39c: Calculated spectrum for $\mathrm{C}_{26} \mathrm{H}_{38} \mathrm{~N}_{7} \mathrm{O}_{15} \mathrm{NiCl} ; 39 \mathrm{~d}$ : Experimental spectrum of peptide $\mathrm{E} \cdot \mathrm{Ni}^{2+}$ complex (higher mass region))

$52 \mathrm{H} 7 \mathrm{~N} 14022 \mathrm{Ni}$

a

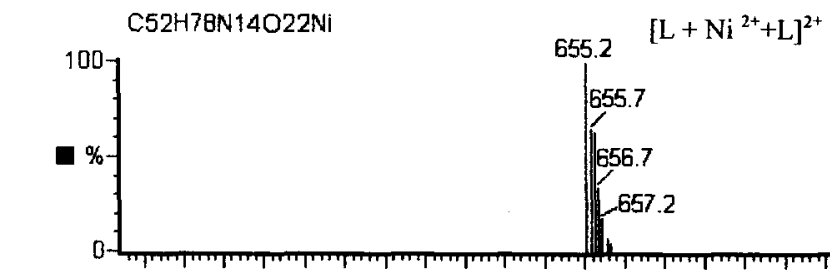

b

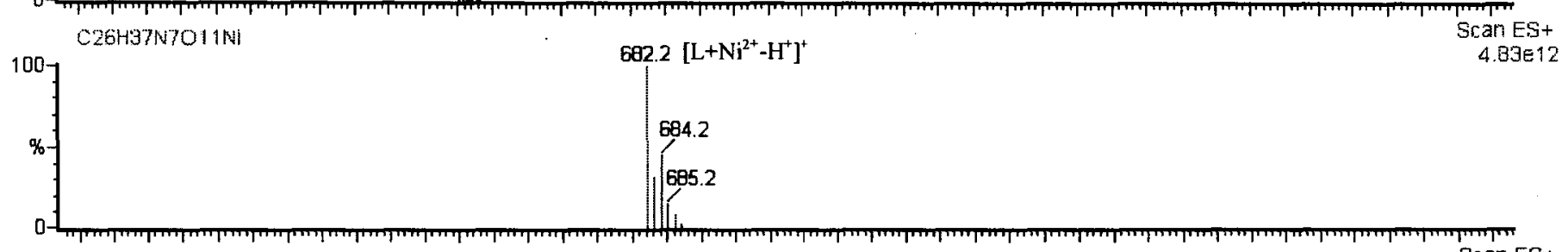

c

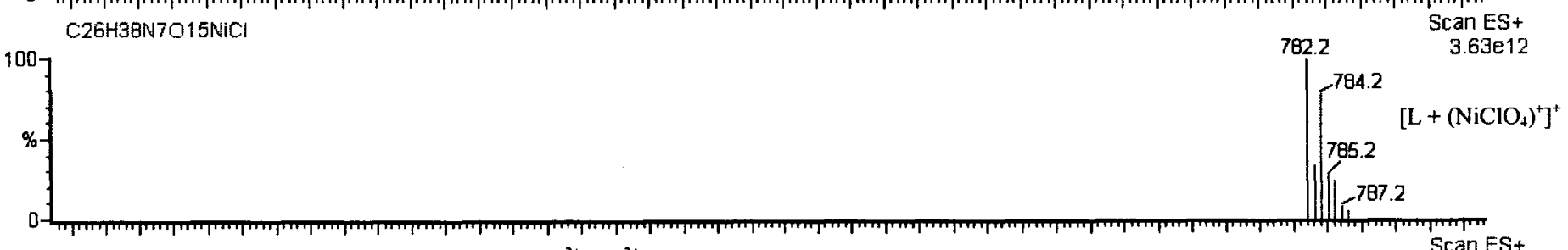

d

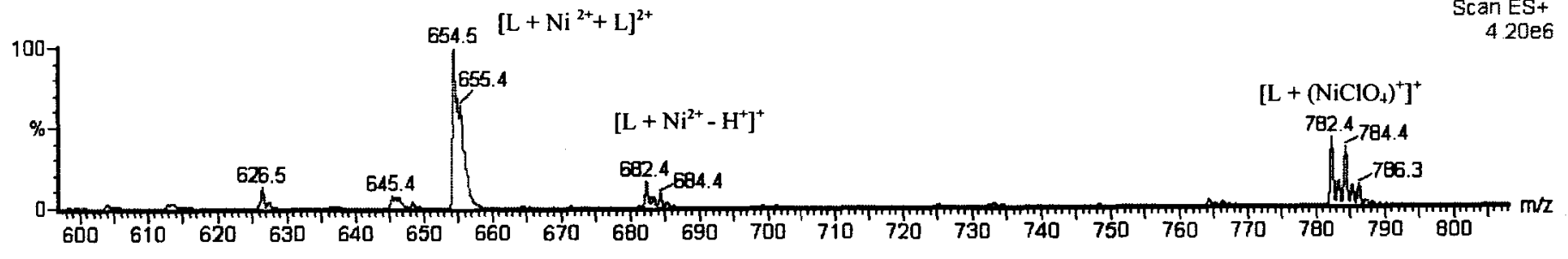


Figure $40 \quad$ ESI-MS study of the peptide $\mathrm{E} \cdot(\mathrm{L}) \mathrm{Zn}^{2+}$ complex

(40a (top) Calculated spectrum for $\mathrm{C}_{26} \mathrm{H}_{37} \mathrm{~N}_{7} \mathrm{O}_{11} \mathrm{Zn} ; 40 \mathrm{~b}$ (bottom) Experimental spectrum of the peptide $\mathrm{E} \cdot \mathrm{Zn}^{2+}$ complex) C26H37N7011Zn
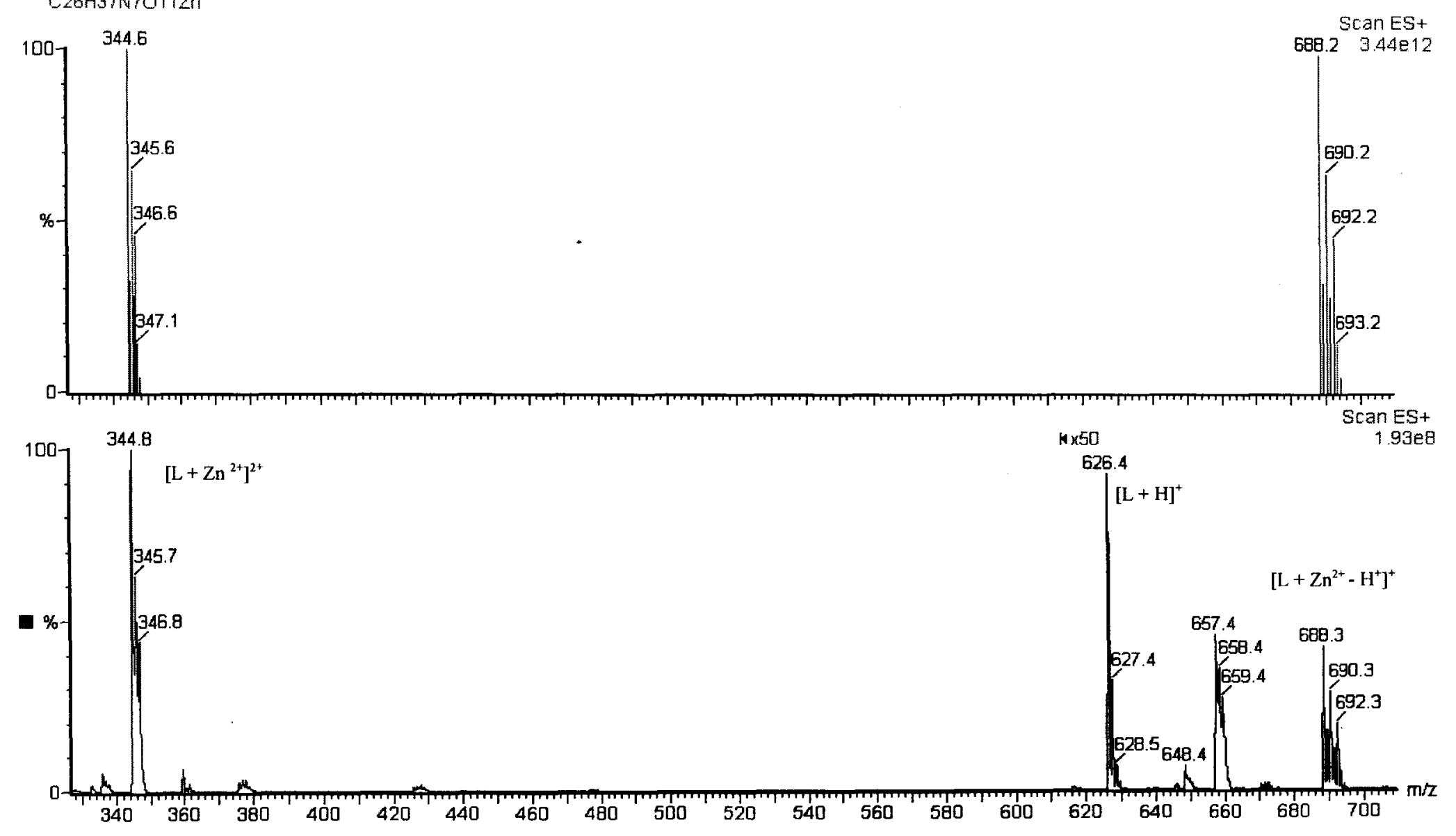
Figure 41 ESI-MS study of the peptide $\mathrm{E} \cdot(\mathrm{L}) \mathrm{Zn}^{2+}$ complex (higher mass region)

(41a (top): Calculated spectrum for $\mathrm{C}_{26} \mathrm{H}_{37} \mathrm{~N}_{7} \mathrm{O}_{11} \mathrm{Zn} ; 41 \mathrm{~b}$ (middle): Calculated spectrum for $\mathrm{C}_{26} \mathrm{H}_{38} \mathrm{~N}_{7} \mathrm{O}_{15} \mathrm{ClZn}$;

41c (bottom): Experimental spectrum of peptide $\mathrm{E} \cdot \mathrm{Zn}^{2+}$ complex (higher mass region)
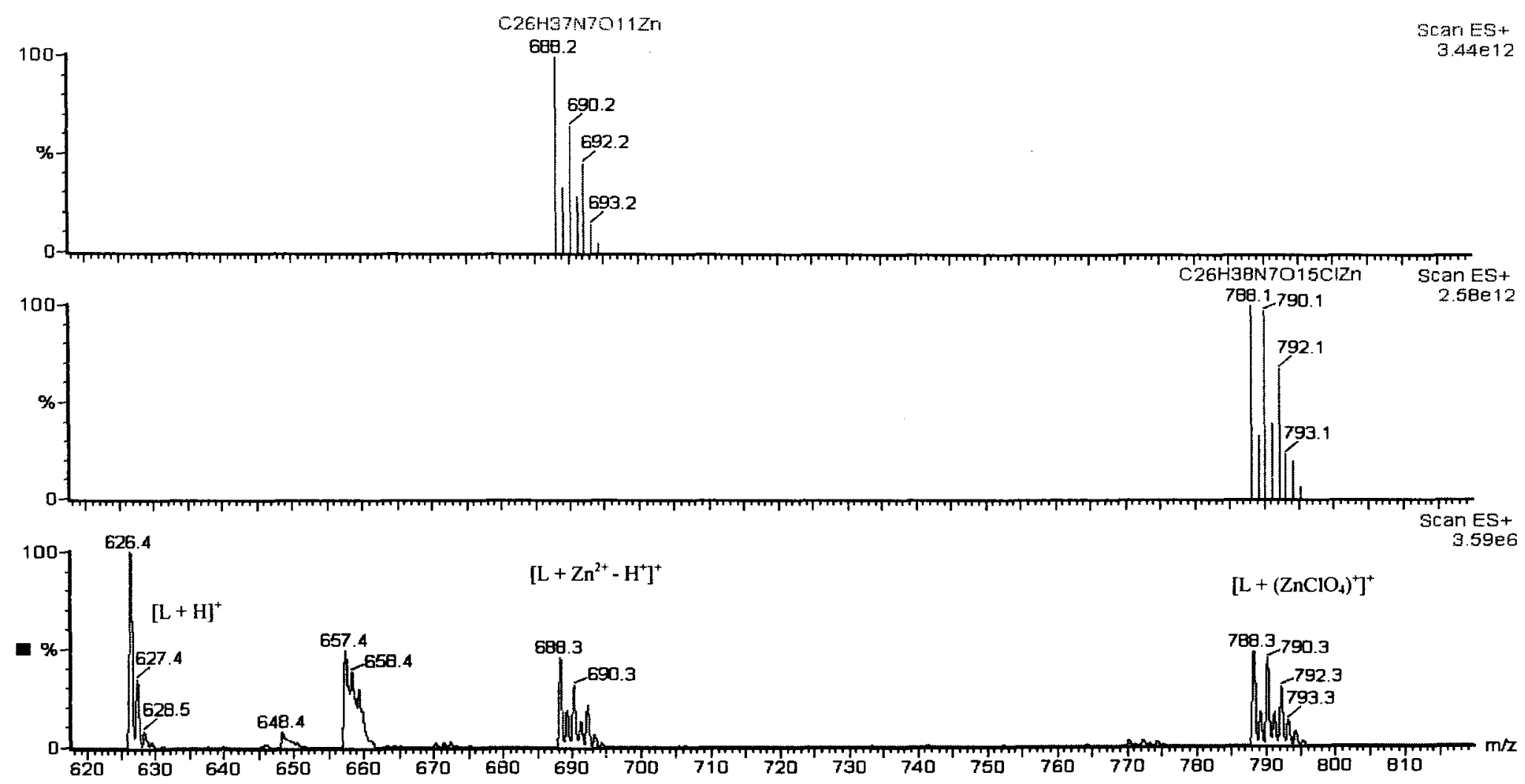
Figure 42 ESI-MS study of the peptide $\mathrm{E}(\mathrm{L}) \cdot \mathrm{Fe}^{3+}$ complex

(42a (top) Calculated spectrum for $\mathrm{C}_{26} \mathrm{H}_{36} \mathrm{~N}_{7} \mathrm{O}_{11} \mathrm{Fe} ; 42 \mathrm{~b}$ (bottom) Experimental spectrum of the peptide $\mathrm{E} \cdot \mathrm{Fe}$ (III) complex)

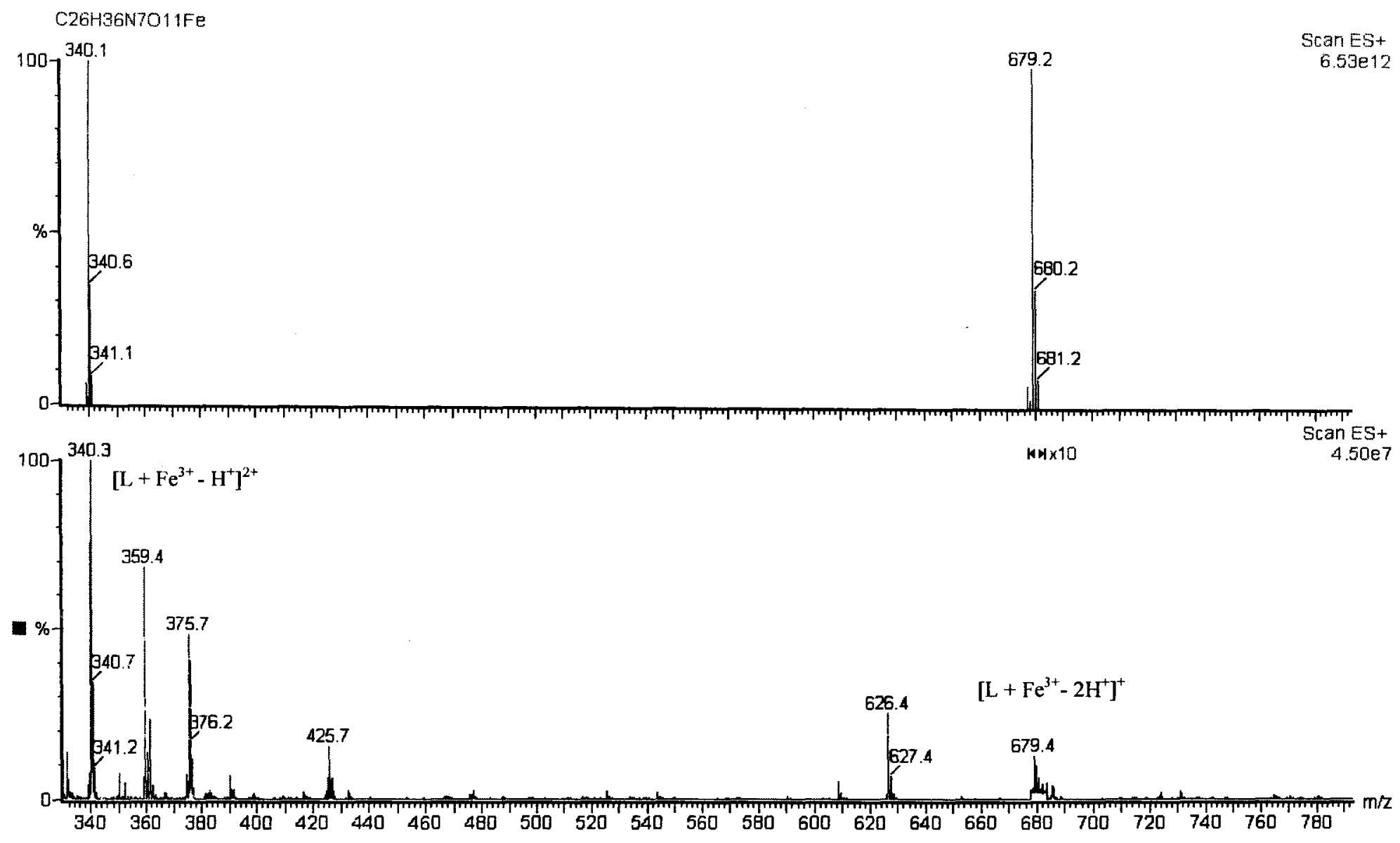


Figure 43a ESI-MS study of complexes of peptide $\mathrm{E}(\mathrm{L})$ with $\mathrm{Fe}\left(\mathrm{ClO}_{4}\right)_{3}, \mathrm{Ni}\left(\mathrm{ClO}_{4}\right)_{2}$ and $\mathrm{Zn}(\mathrm{ClO})_{2}$

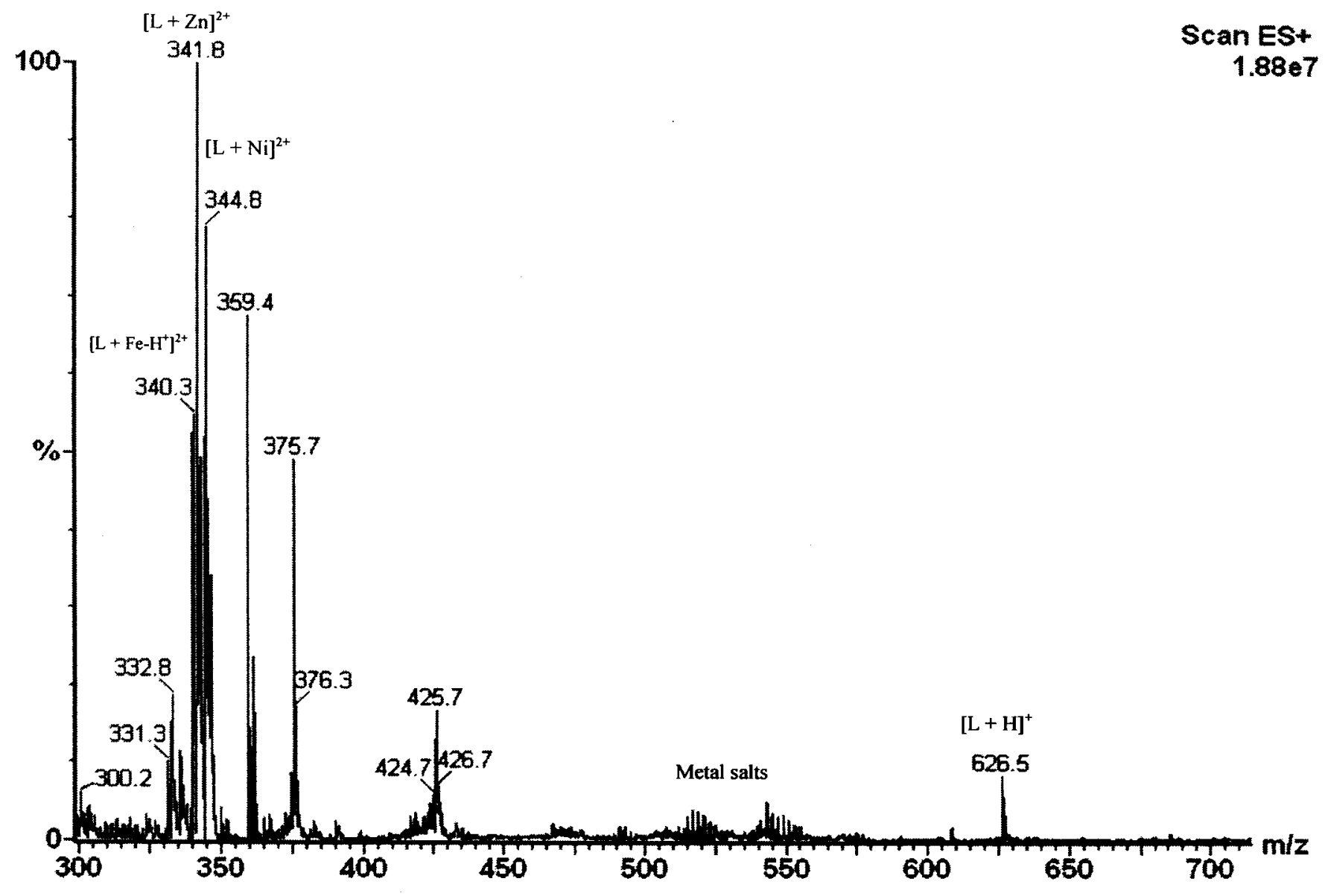


Figure 43b-e ESI-MS study of complexes of peptide $\mathrm{E}(\mathrm{L})$ with $\mathrm{Fe}\left(\mathrm{ClO}_{4}\right)_{3}, \mathrm{Ni}\left(\mathrm{ClO}_{4}\right)_{2}$ and $\mathrm{Zn}\left(\mathrm{ClO}_{4}\right)_{2}$ (lower mass region) (43b: Calculated spectrum for $\mathrm{C}_{26} \mathrm{H}_{36} \mathrm{~N}_{7} \mathrm{O}_{11} \mathrm{Fe} ; 43 \mathrm{c}$ : Calculated spectrum for $\mathrm{C}_{26} \mathrm{H}_{37} \mathrm{~N}_{7} \mathrm{O}_{11} \mathrm{Zn}$; 43d: Calculated spectrum for $\mathrm{C}_{26} \mathrm{H}_{37} \mathrm{~N}_{7} \mathrm{O}_{11} \mathrm{Ni}$; 43e: Experimental spectrum of complexes of peptide $\mathrm{E}$ with $\mathrm{Fe}\left(\mathrm{ClO}_{4}\right)_{3}, \mathrm{Ni}\left(\mathrm{ClO}_{4}\right)_{2}$ and $\left.\mathrm{Zn}\left(\mathrm{ClO}_{4}\right)_{2}\right)$

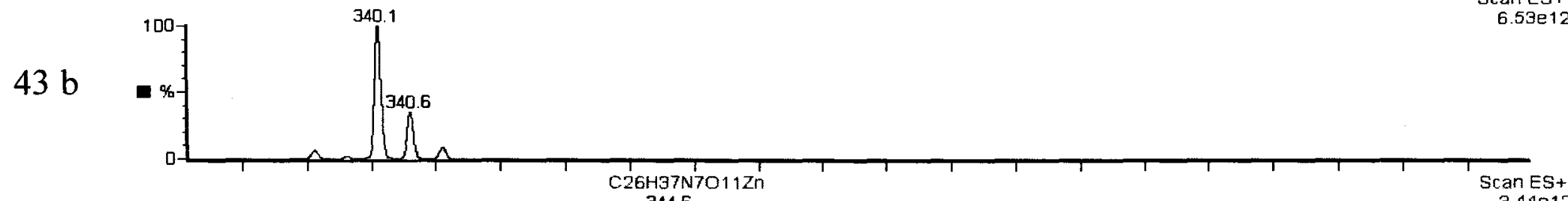

$43 \mathrm{c}$

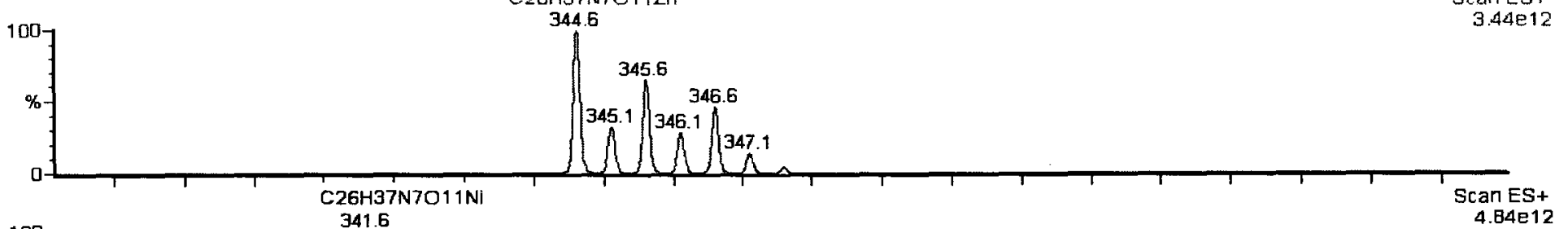

$43 d$

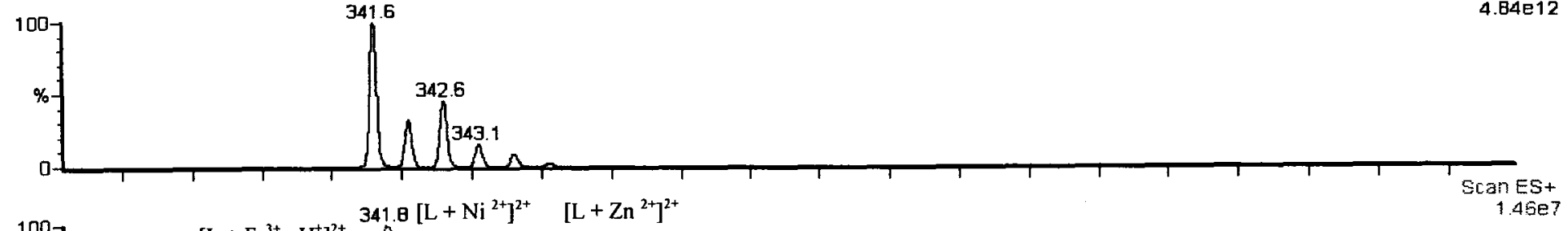

43 e

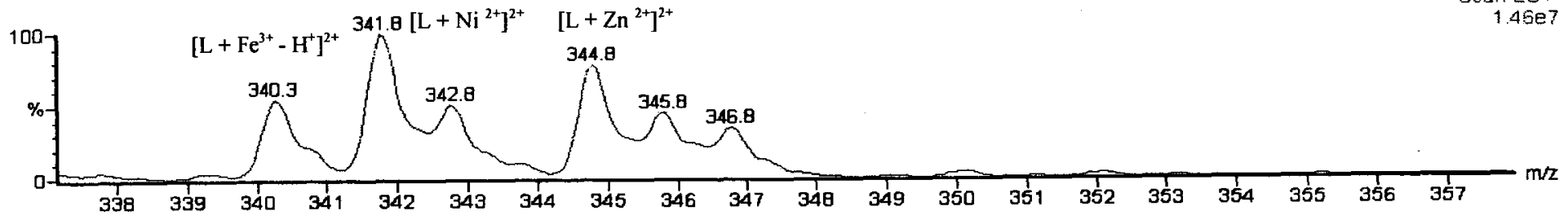




\section{Metal Binding Study of Peptide H (Ac-Gly ${ }_{1}-\mathrm{Glu}_{2}(\mathrm{NHOH})-\mathrm{D}-\mathrm{Pro}_{3}-$}

\section{Gly $_{4}$-Glu 5 (NHOH)-D-Pro 6 -NH NH $_{2}$ with ESI-MS}

As with peptide $\mathrm{E}$, peptide $\mathrm{H}$ single metal binding was studied by ESI-MS. However, these individual complex spectra gave a rather complicated pattern, since large fragment ion peaks were observed, and they were further examined by MS/MS. These results will be discussed in the peptide fragmentation section. The data for the peptide $\mathrm{H}$ metal mixture competitive study was more straightforward and is outlined here (Figure 44 - 47). In the following section, $\mathrm{L}$ refers to the free ligand hydroxamic acid peptide $\mathrm{H}$.

Based on the need of experiments free ligand (peptide $\mathrm{H}$ ) was mixed with metal ions $\mathrm{Fe}^{3+}, \mathrm{Zn}^{2+}$ and $\mathrm{Ni}^{2+}$ in different ratios in water-acetonitrile (1:1) solution. Formic acid was added to adjust the $\mathrm{pH}$ value to 5 . Figure 44 illustrates the ESI-MS spectrum of peptide $\mathrm{H}$ binding to metal mixtures in different ratios. First, the free ligand was mixed with metal salts in the ratio of peptide $\mathrm{H}: \mathrm{Fe}^{3+}: \mathrm{Ni}^{2+}: \mathrm{Zn}^{2+}=1: 1: 1: 1$, and only an $[\mathrm{L}+$ $\left.\mathrm{Fe}^{3+}-2 \mathrm{H}^{+}\right]^{+}$ion was observed in the ESI-MS spectrum, which demonstrates that the ligand exclusively binds $\mathrm{Fe}(\mathrm{III})$. Neither the free ligand, nor peptide $\mathrm{H}$ bound with zinc or peptide $\mathrm{H}$ bound with nickel complex ions was observed. Second a mixture of peptide $H$ : $\mathrm{Fe}^{3+}: \mathrm{Ni}^{2+}: \mathrm{Zn}^{2+}=3: 1: 1: 1$ was subjected to ESI-MS; in this particular solution enough ligand is available for all the metal to bind. Nevertheless, the ESI-MS result demonstrated that $\left[\mathrm{L}+\mathrm{Fe}^{3+}-2 \mathrm{H}^{+}\right]^{+}$was still the predominant ion while an $\left[\mathrm{L}+\mathrm{Zn}^{2+}-\mathrm{H}^{+}\right]^{+}$ion was observed only in low intensity, and some free ligand molecular ion was also detected. Finally, the peptide $\mathrm{H}$ was introduced to a metal salt mixture in which $\mathrm{Fe}^{3+}$ was in very low concentration compared to other metals (peptide $\mathrm{H}: \mathrm{Fe}^{3+}: \mathrm{Ni}^{2+}: \mathrm{Zn}^{2+}=1: 0.1: 1: 1$ ). In this experiment, the peak of ion $\left[\mathrm{L}+\mathrm{Fe}^{3+}-2 \mathrm{H}^{+}\right]^{+}$is in similar intensity to the $\left[\mathrm{L}+\mathrm{Ni}^{2+}\right.$ - 
$\left.\mathrm{H}^{+}\right]^{+}$peak, and the $\left[\mathrm{L}+\mathrm{Zn}^{2+}-\mathrm{H}^{+}\right]^{+}$ion was twice as intense. Most of the peptide remained as a free ligand in this iron deficient environment. Then the peptide $\mathrm{H}$ was introduced in a mixture where $\mathrm{Ni}^{2+}$ and $\mathrm{Zn}^{2+}$ were in large excess compared to $\mathrm{Fe}^{3+}$ (peptide $\mathrm{H}: \mathrm{Fe}^{3+}: \mathrm{Ni}^{2+}: \mathrm{Zn}^{2+}=1: 1: 10: 10$ ), and only a peptide $\mathrm{H} \cdot \mathrm{Fe}(\mathrm{III})$ adduct was observed in this case (Figure 45). This observation demonstrated that peptide $\mathrm{H}$ binds $\mathrm{Fe}(\mathrm{III})$ to a much greater extent than $\mathrm{Zn}$ (II) or $\mathrm{Ni}(\mathrm{II})$ and the peptide $\mathrm{H} \cdot \mathrm{Fe}(\mathrm{III})$ complex is outstandingly stable. Fe(III) could not be replaced by divalent $\mathrm{Zn}$ (II) and $\mathrm{Ni}$ (II) ions in this experiment, even the divalent ions existing in much higher concentrations.

This hypothesis was further strengthened by the final experiment in this series. Peptide $\mathrm{H}$ was mixed with $\mathrm{Ni}\left(\mathrm{ClO}_{4}\right)_{2}$ and $\mathrm{Zn}\left(\mathrm{ClO}_{4}\right)_{2}$ in the ratio of 1: 1: 1 and free peptide, peptide $\mathrm{H} \cdot \mathrm{Ni}(\mathrm{II})$ and peptide $\mathrm{H} \cdot \mathrm{Zn}(\mathrm{II})$ peaks were observed in a ratio of $1: 1$ : 1.2 (relative peak abundance ratio) (Figure 46, top spectrum) in ESI-MS study. Then one equivalent $\mathrm{Fe}\left(\mathrm{ClO}_{4}\right)_{3}$ was introduced to the mixture, and, as shown in Figure 44 top spectrum, only peptide $\mathrm{H} \cdot \mathrm{Fe}$ (III) complex was detected (Figure 46, bottom spectrum). Therefore, no matter what the sequence of metal introduction to the ligand, the ligand showed a predominant preference for Fe(III), which can replace the pre-adducted metal thoroughly and effectively. Based on the ESI-MS experiment data obtained in these competitive metal binding exams, we conclude that metal binding preference of peptide $\mathrm{H}$ is $\mathrm{Fe}^{3+}>\mathrm{Zn}^{2+}>\mathrm{Ni}^{2+}$ at $\mathrm{pH}=5$.

To study the $\mathrm{pH}$ effect on peptide $\mathrm{H}$ metal binding behavior, we carried out one of the competitive metal binding experiments under more acidic conditions $(\mathrm{pH}=2)$. After comparing the ESI-MS spectra obtained at different $\mathrm{pH}$ values (Figure 47), we did not observe any major changes of peptide $\mathrm{H}$ metal selectivity, and the peptide $\mathrm{H}$ iron 
complex was still found to be the almost exclusive ligand-metal species. Therefore the dihydroxamic acid peptide was shown to be a very selective siderophore analogue with significant preference for $\mathrm{Fe}(\mathrm{III})$ compared to $\mathrm{Zn}(\mathrm{II})$ or Ni(II) between $\mathrm{pH} 25$. 
Figure 44 Metal binding selectivity test of peptide $H(L)$ and metal mixtures in different ratios
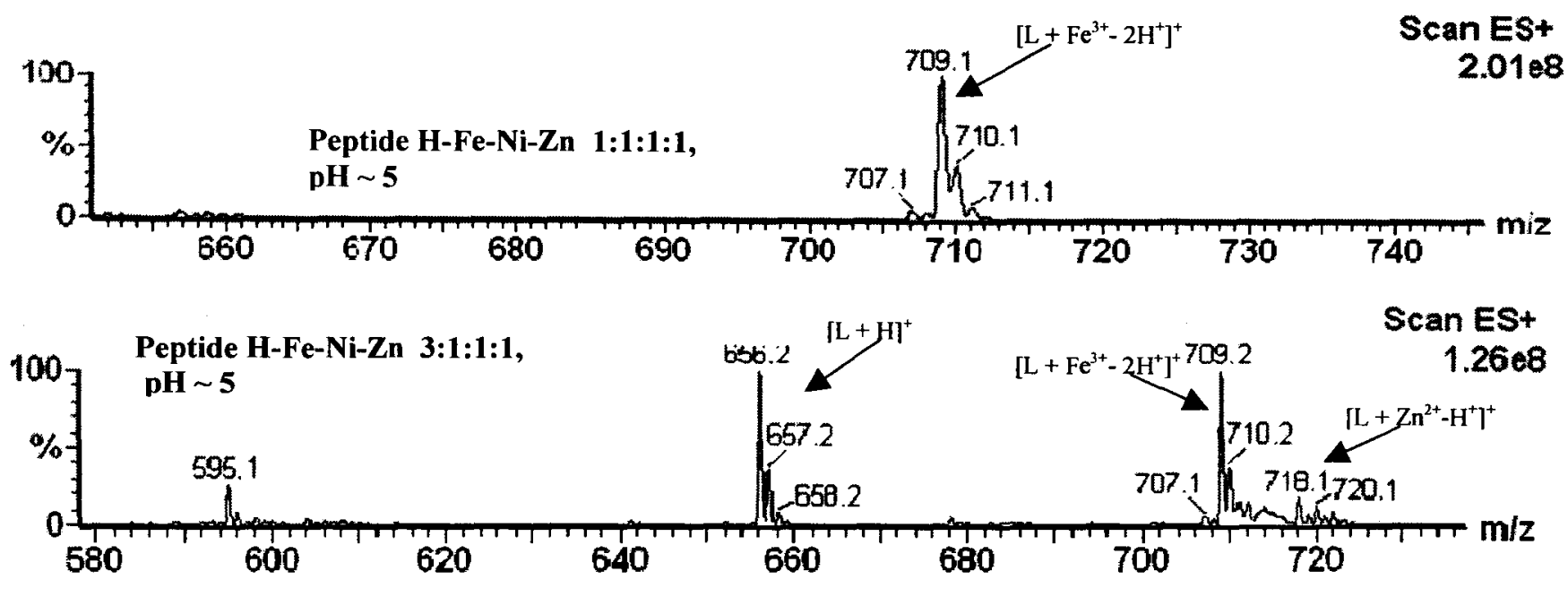

Peptide H-Fe-Ni-Zn 1: 0.1:1:1,

pH $\sim 5$

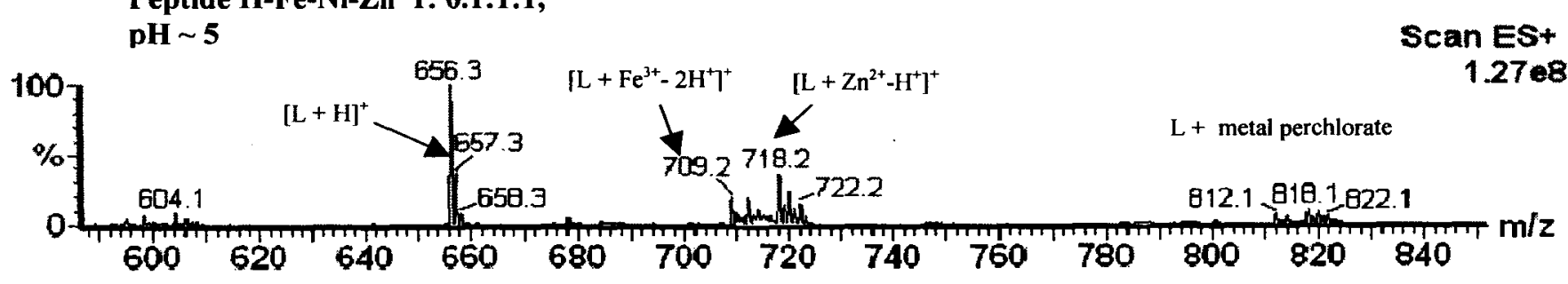

Scan ES+

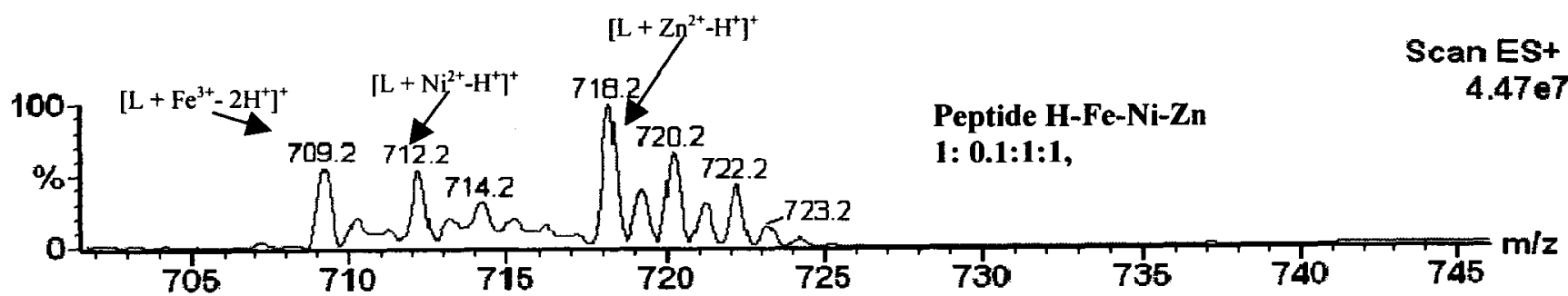


Figure 45 Metal binding selectivity test with peptide $\mathrm{H}(\mathrm{L})$ and metal mixtures (peptide $\mathrm{H}: \mathrm{Fe}^{3+}: \mathrm{Ni}^{2+}: \mathrm{Zn}^{2+}=1: 1: 10: 10$ ) (45a (top) Calculated spectrum for $\mathrm{C}_{26} \mathrm{H}_{38} \mathrm{~N}_{9} \mathrm{O}_{11} \mathrm{Fe} ; 45 \mathrm{~b}$ (bottom) Experimental spectrum of peptide $\mathrm{H} \cdot$ metal complex)

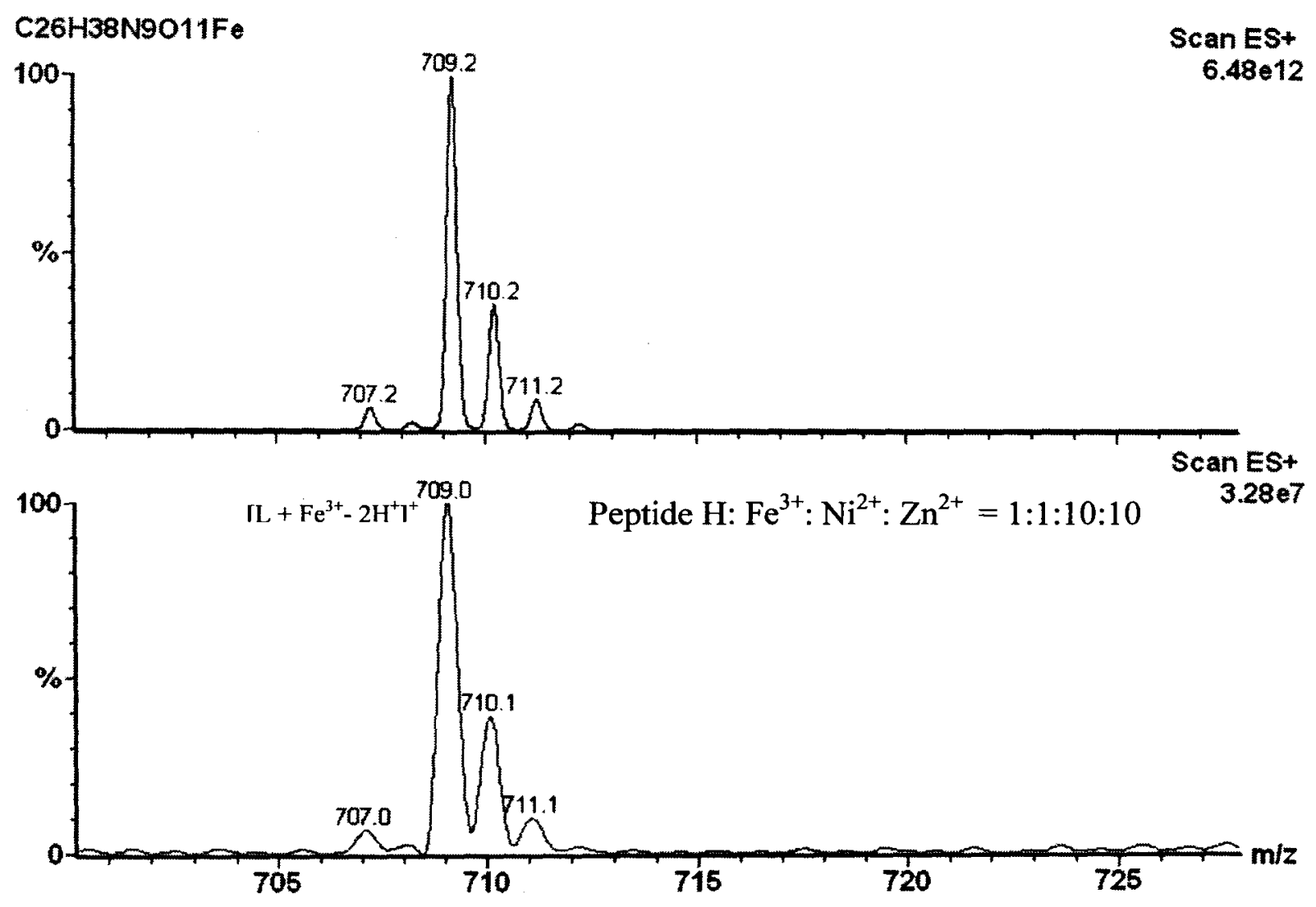


Figure 46 Metal binding selectivity comparison study of peptide H (L) with and without Fe (III)

Peptide $\mathrm{H}: \mathrm{Ni}: \mathrm{Zn}=1: 1: 1$

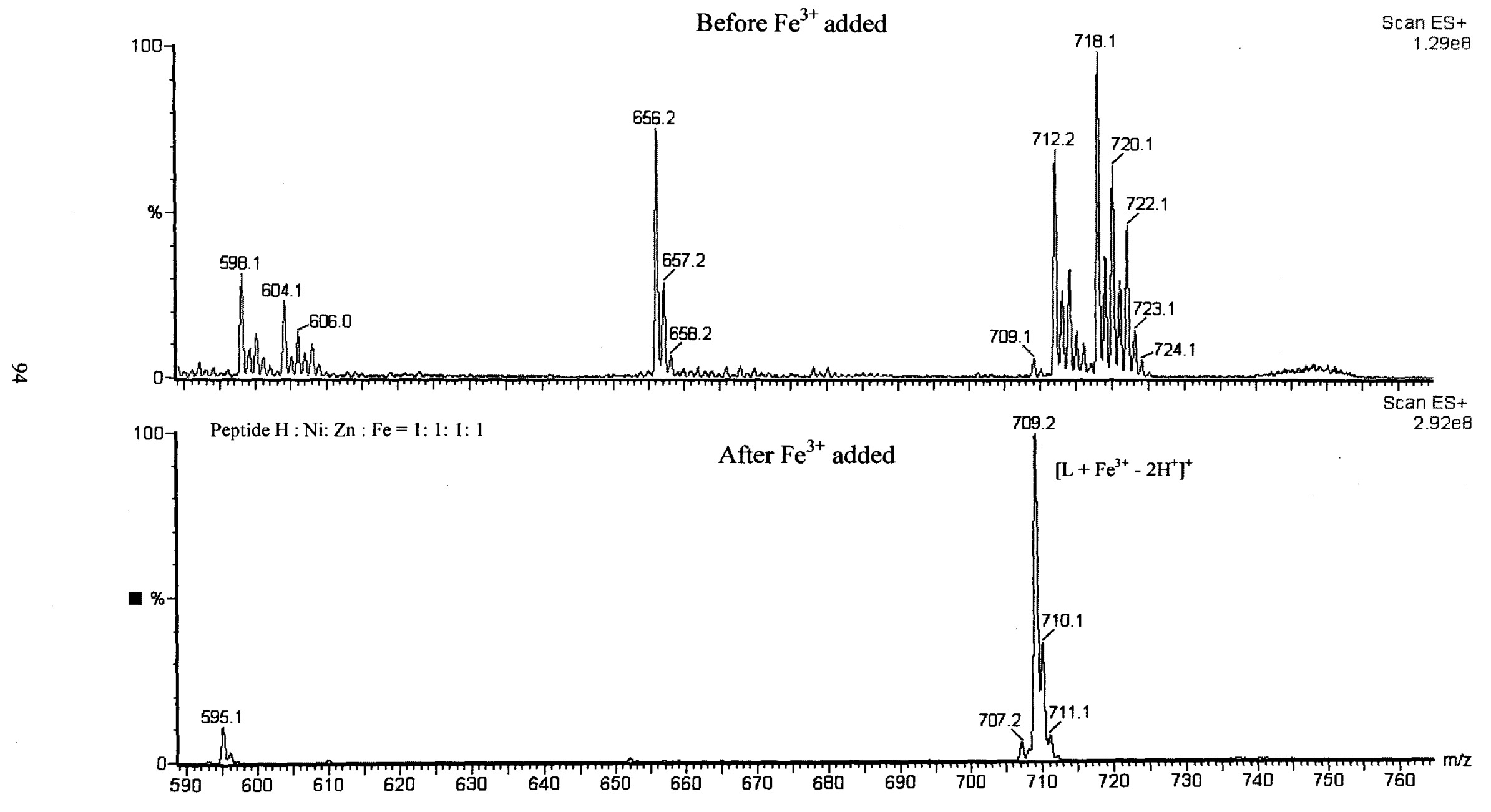


Figure 47 ESI-MS of peptide $\mathrm{H}(\mathrm{L})-\mathrm{Fe}^{3+}-\mathrm{Ni}^{2+}-\mathrm{Zn}^{2+}(1: 1: 1: 1)$ at $\mathrm{pH} \sim 5$ vs $\mathrm{pH} \sim 2$

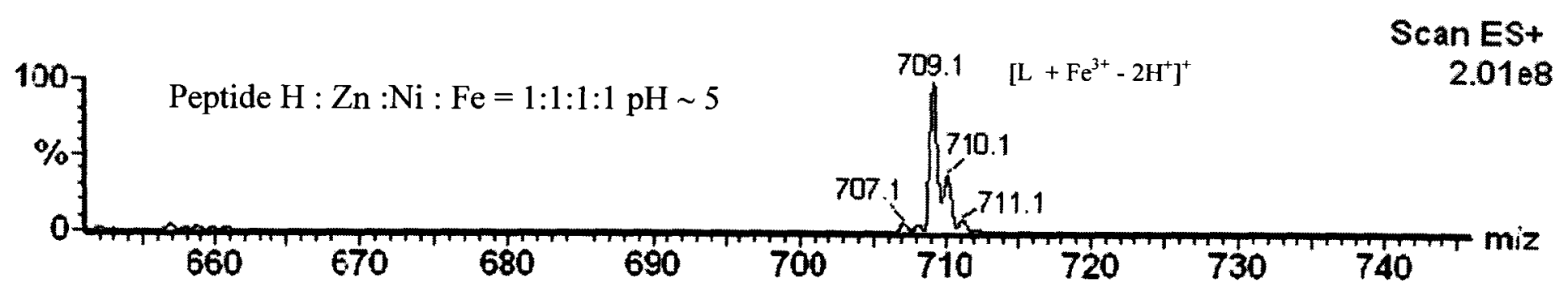

ư

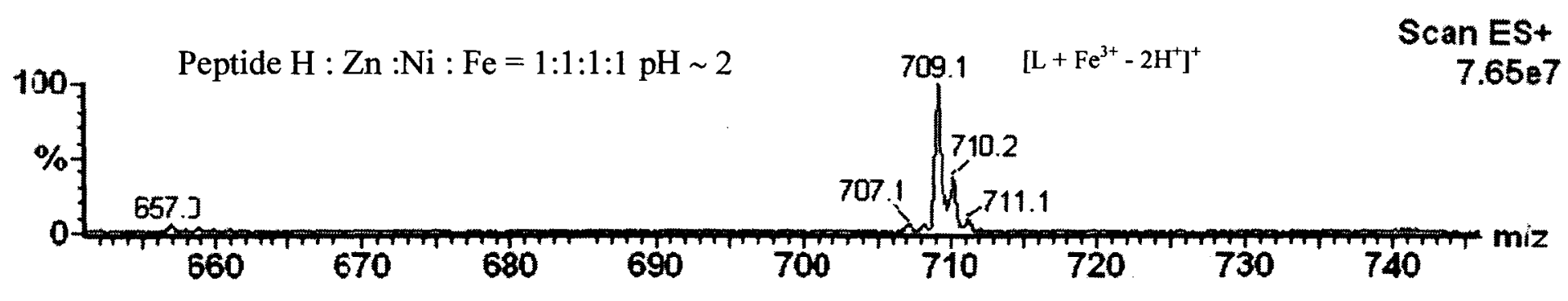




\section{Peptide Fragmentation (Tandem MS/ MS)}

The types of fragment ions observed in an MS/MS spectrum depend on the primary sequence, the amount of internal energy, how the energy was introduced and charge state. In low energy CID (collision induced dissociation) study, a peptide carrying fragments with positive charge one mainly along its backbone, generates predominantly sequential ions. A fragment is only detected if it carries at least one charge. Johnson modified the nomenclature of the fragment ions proposed by Roepstorff and Fohlman (Roepstorff and Fohlman, 1984) by defining the ion as either $a, b$ or $c$ when the charge is retained on the $\mathrm{N}$ terminal fragment, or either $x, y$ or $z$ when the charge in retain on the $\mathrm{C}$ terminal fragment. The cleavage can occur between a $\mathrm{C}-\mathrm{C}$ bond, giving $a$ and $x$ ions, between a C-N bond, giving $b$ and $y$ ions, or between a N-C bond, giving $c$ and $z$ ions (Figure 48) (Johnson, 1988). Subscripts indicate the number of residues in a fragment. For example, the following peptide containing four amino acid residues could be fragmented into $a_{1}-a_{3}, b_{1}-b_{3}, c_{1}-c_{3}, x_{1}-x_{3}, y_{1}-y_{3}$ and $z_{1}-z_{3}$, as eighteen ions in total.

Fragmentation of peptide $\mathrm{E}\left(\mathrm{Ac}-\mathrm{G}_{1} \mathrm{E}_{2} \mathrm{dP}_{3} \mathrm{G}_{4} \mathrm{E}_{5} \mathrm{dP}_{6}-\mathrm{NH}_{2}\right)$ was studied by tandem MS/MS. Based on the detected fragment ions shown in Figure 49, we proposed that the sites of peptide chain cleavage included the amide bonds between $\mathrm{Glu}_{2}-\mathrm{Pro}_{3}, \mathrm{Pro}_{3}-\mathrm{Gly}_{4}$, $\mathrm{Gly}_{4}-\mathrm{Glu}_{5}$ and $\mathrm{Glu}_{5}-\mathrm{Pro}_{6}$, and these cleavages could provide eight fragment ions (Figure 50). Five fragments were clearly detected and assigned with certain structures, but the $b_{2}$, $y_{2}$ and $y_{3}$ fragments were not observed. We found the amide bonds between Glu and Pro are the most fragile bonds in peptide $E$, since the detection of $b_{5}, y_{1}, y_{4}$ is the result of amide bond scission of $\mathrm{Glu}_{5}-\mathrm{Pro}_{6}$ or $\mathrm{Glu}_{2}-\mathrm{Pro}_{3}$. The fact that the tertiary proline amide 
could be transferred to the more stable secondary amine after the bond scission, could explain the bond scission between Glu and Pro.

Figure 48 Peptide fragment nomenclature

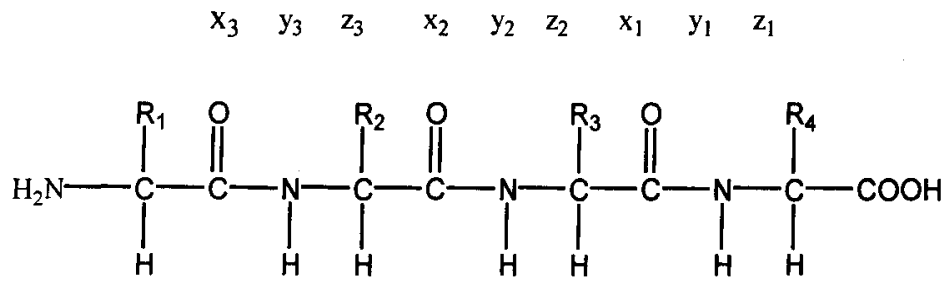

$\begin{array}{lllllllll}a_{1} & b_{1} & c_{I} & a_{2} & b_{2} & c_{2} & a_{3} & b_{3} & c_{3}\end{array}$<smiles>[R2]C=[NH+]C(=O)C([R7])N</smiles>

$a_{2}$<smiles>[R]C(N)C(=O)N([2H])C([R2])([R])C#[O+]</smiles>

$\mathrm{b}_{2}$<smiles>[R2]C([NH3+])N([2H])C(=O)C([R])([R])N</smiles>

$\mathrm{c}_{2}$<smiles>[R4]C(C(=O)O)C(=O)N([2H])C([R])[R3]</smiles><smiles>[R]C([NH3+])C(=O)N([2H])C([R2])([R])C(=O)O</smiles>

$\mathrm{y}_{2}$<smiles>[R3][CH+]C(=O)N([2H])C([R4])C(=O)O</smiles>

$\mathbf{Z}_{2}$

The fragment with a mass of 284 was shown as the most significant peak among the daughter peaks of 626 (Figure 49); however, this mass did not belong to any Cterminal or $\mathrm{N}$-terminal fragment of peptide $\mathrm{E}$ based on the peptide fragment nomenclature described in Figure 48. We boldly proposed that the fragment with a mass 
of 284 could be generated from a double cleavage of peptide E. If the amide bonds between $\mathrm{Glu}_{2}-\mathrm{Pro}_{3}$ and $\mathrm{Glu}_{5}-\mathrm{Pro}_{6}$ could be cleaved simultaneously, three fragments would be generated including Ac-Gly $-\mathrm{Glu}_{2}(\mathrm{~b} 2)$, $\mathrm{Pro}_{6}-\mathrm{NH}_{2}$ (y1) and $\mathrm{Pro}_{3}-\mathrm{Gly}_{4}-\mathrm{Glu}_{5}$ (with a mass of 284). Although no evidence of double cleavage to a peptide chain has been reported yet, we still could rationalize our proposal based on the unique properties of our peptides. Peptide E contained repetitive amino acids including two prolines in the sequence. In the process of ionization, the amide bonds between $\mathrm{Glu}_{2}$ and $\mathrm{Pro}_{3}$ and $\mathrm{Glu}_{5}$ and $\mathrm{Pro}_{6}$ are the equally most fragile links in the peptide, which has also been proven by other fragmentation routes of peptide $\mathrm{E}$ (Figure 50). Because of these similar properties, two amide bonds could be cleaved at the same time and provide three fragments including b2 and y1 and fragment 284 (proposed as PGE) (Figure 51). Later we did the fragmentation study of peptide $\mathrm{H}$, which is the hydroxamic acid analogue of peptide $\mathrm{E}$ and also contains the repetitive sequence involving Glu-Pro. Similar results were obtained in peptide $\mathrm{H}$ system, which further verified this double fragmentation proposal.

The fragment ion with a mass of 256 could originate from the fragment with a mass of 284 (PGE) by losing a water molecule (Figure 49). The fragmentation study of peptide $E$ illustrated the weakest link in peptide $E$ and demonstrated the possible fragment pieces in an MS/MS study. 
Figure 49 Daughter ions of peptide $\mathrm{E}(\mathrm{m} / \mathrm{z}=626.2)$

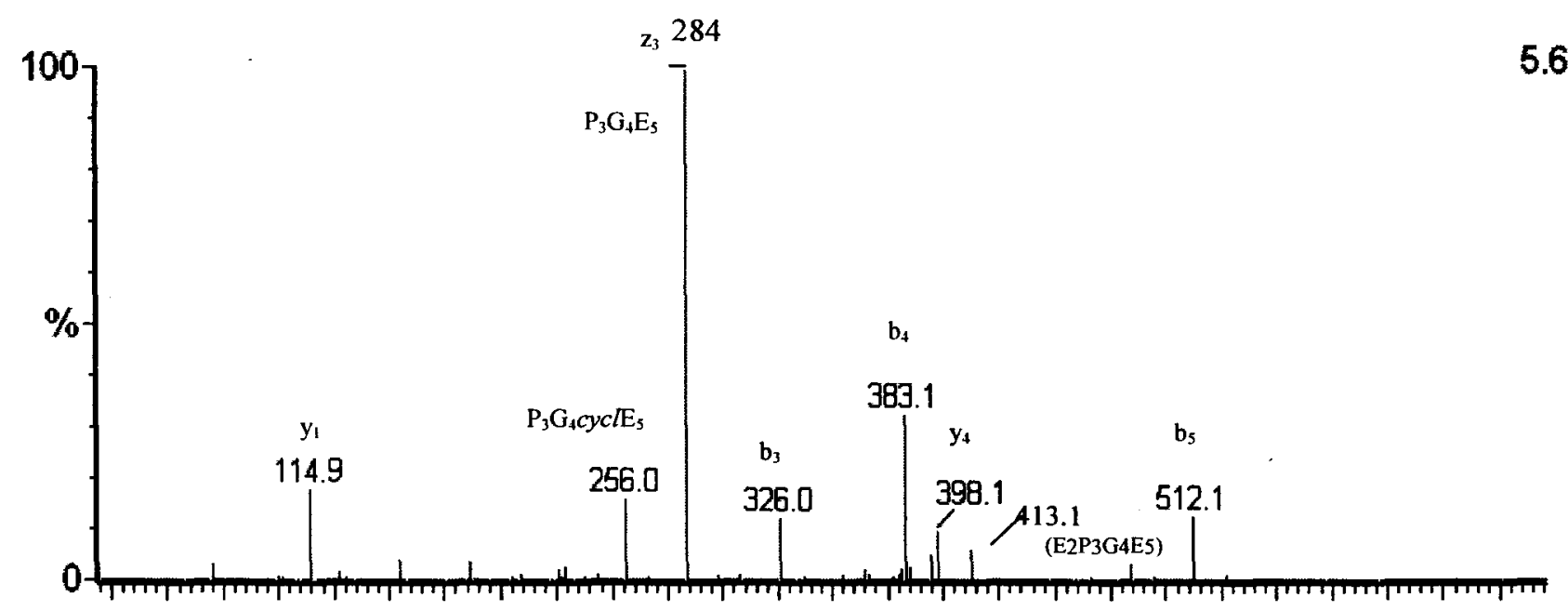


Figure 50 Proposed fragmentation route of peptide $\mathrm{E}\left(\mathrm{Ac}-\mathrm{GE}_{\mathrm{d}} \mathrm{PGE}_{\mathrm{d}} \mathrm{P}-\mathrm{NH}_{2}\right)$

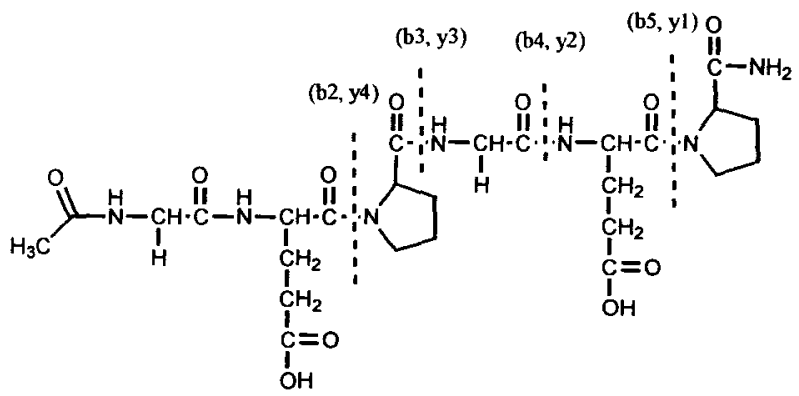

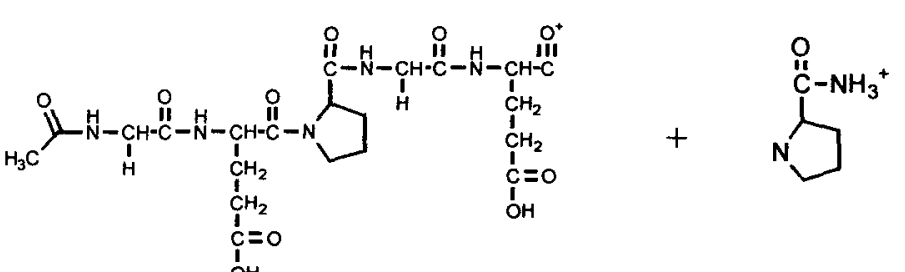

b5 $(\mathrm{m} / \mathrm{z}=512)$

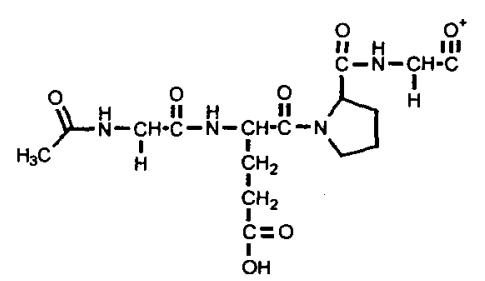

b4 $(\mathrm{m} / \mathrm{z}=383)$ $\mathrm{y} 1(\mathrm{~m} / \mathrm{z}=115)$

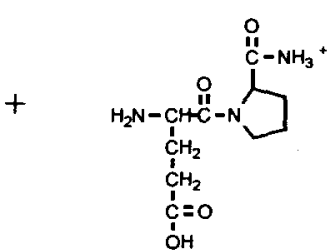

$\mathrm{y} 2(\mathrm{~m} / \mathrm{z}=243)$

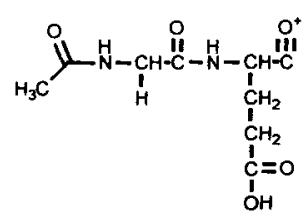

b2 $(m / z=229$, undetected $)$

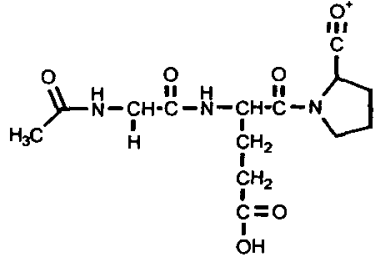

b3 $(\mathrm{m} / \mathrm{z}=326)$

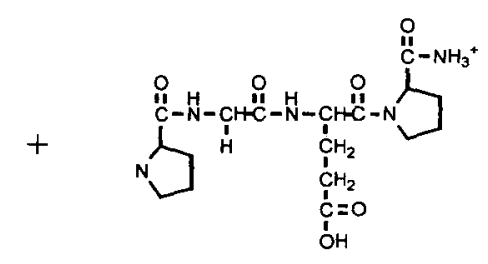

$\mathrm{y} 4(\mathrm{~m} / \mathrm{z}=398)$

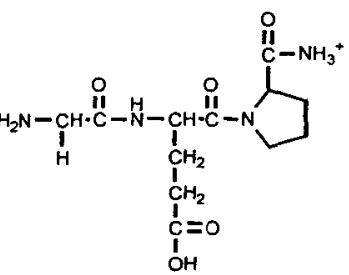

y3 $(\mathrm{m} / \mathrm{z}=301$, undetected $)$ 
Figure 51 Proposed double cleavage route of peptide E

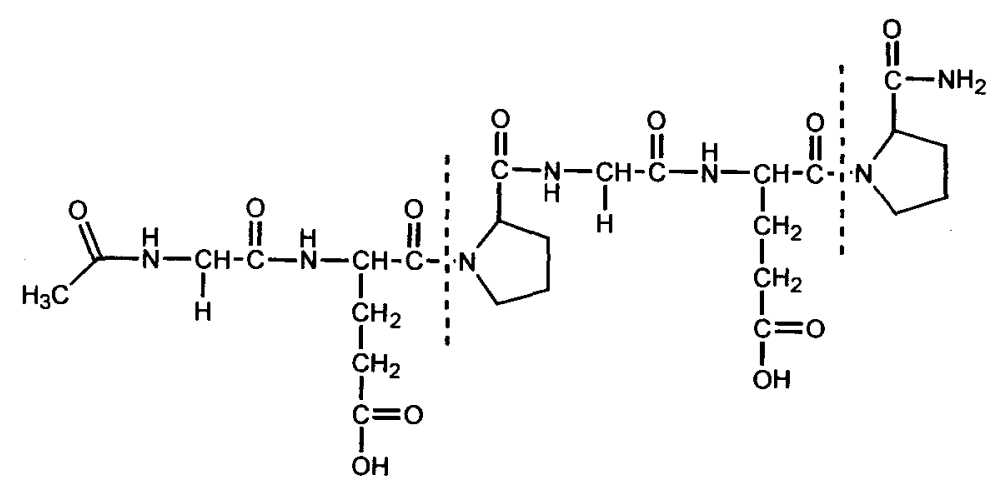

ㅎ
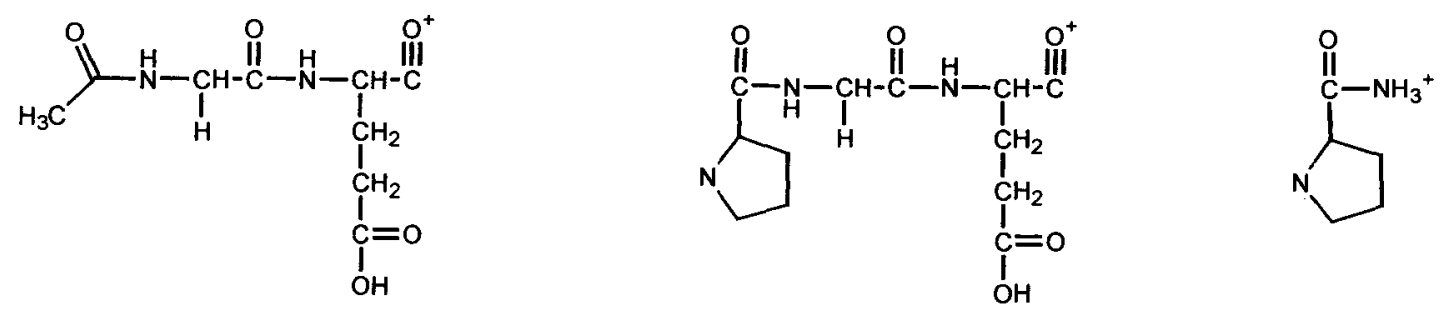

b2 $(\mathrm{m} / \mathrm{z}=229)$

$\operatorname{PGE}^{+}(\mathrm{m} / \mathrm{z}=284)$

yl $(\mathrm{m} / z=115)$ 
The CID experimental results for both free peptide $\mathrm{H}$ (Ac$\left.\mathrm{G}_{1} \mathrm{E}_{2}(\mathrm{NHOH}) \mathrm{dP}_{3} \mathrm{G}_{4} \mathrm{E}_{5}(\mathrm{NHOH}) \mathrm{dP}_{6}-\mathrm{NH}_{2}\right)$ and peptide $\mathrm{H}$ plus individual metals are summarized in Table 10 and Figure 52. The daughter peaks of peptide $\mathrm{H}$ molecular mass peak $(\mathrm{m} / \mathrm{z}=656)$ include fragment ions peaks shown at $542,509,413,380$ and 299 . As with peptide $\mathrm{E}$, the amide bond between $\mathrm{Glu}_{5}(\mathrm{NHOH})$ and $\mathrm{Pro}_{6}$ appears to be the most readily cleaved giving $\left[\mathrm{Ac}-\mathrm{G}_{1} \mathrm{E}_{2}(\mathrm{NHOH}) \mathrm{dP}_{3} \mathrm{G}_{4} \mathrm{E}_{5}(\mathrm{NHOH})\right]^{+}\left(\mathrm{b}_{5}\right)$ with a mass of 542 and $\left[\text { Pro- } \mathrm{NH}_{2}\right]^{+}\left(\mathrm{y}_{1}\right)$ with a mass of 115 (Figure 54). We assume that the fragment ion $\mathrm{b}_{5}$ can self-cyclize into a more stable N-hydroxysuccimide cation, which also has a mass of 542, thus both linear or cyclic ions can account for fragment 2 observed in MS/MS (Figure 55). Fragment 3 appeared to be the result of fragment 1 (linear or cyclized form) losing an $\mathrm{NHOH}$ group on either the $\mathrm{Glu}_{2}(\mathrm{NHOH})$ or $\mathrm{Glu}_{5}(\mathrm{NHOH})$ residue by path 1,2 or 3 (Figure 55). Therefore, there could be three kinds of ions matching the mass of 509 (Fragment 3) as shown in Figure 55. In this self-cyclization process the glutamine backbone $\mathrm{N}$ could attack its glutamine hydroxamate side chain carbonyl group, followed by elimination of the $\mathrm{NHOH}$ group, resulting in the formation of a stable five-membered lactam ring.

The amide bond cleavage between $\mathrm{Glu}_{2}(\mathrm{NHOH})$ and $\mathrm{Pro}_{3}$ provided fragment 6 and fragment 12. For fragment 6 , the glutamic acid backbone $\mathrm{N}$ could attack its hydroxamate side chain carbonyl group, and $\mathrm{NHOH}$ group was the leaving group, resulting in the final formation of lactam fragment ion 8 (Figure 56). 
Figure 52 ESI study of peptide $\mathrm{H}$ with varying ionization voltages providing fragments for MS/ MS analysis

(top spectrum, daughter peaks of the peptide $\mathrm{H}$ molecular ion peak $(\mathrm{m} / \mathrm{z}=656)$;

bottom spectrum, parent peak of the fragment ion peak $(\mathrm{m} / \mathrm{z}=299)$

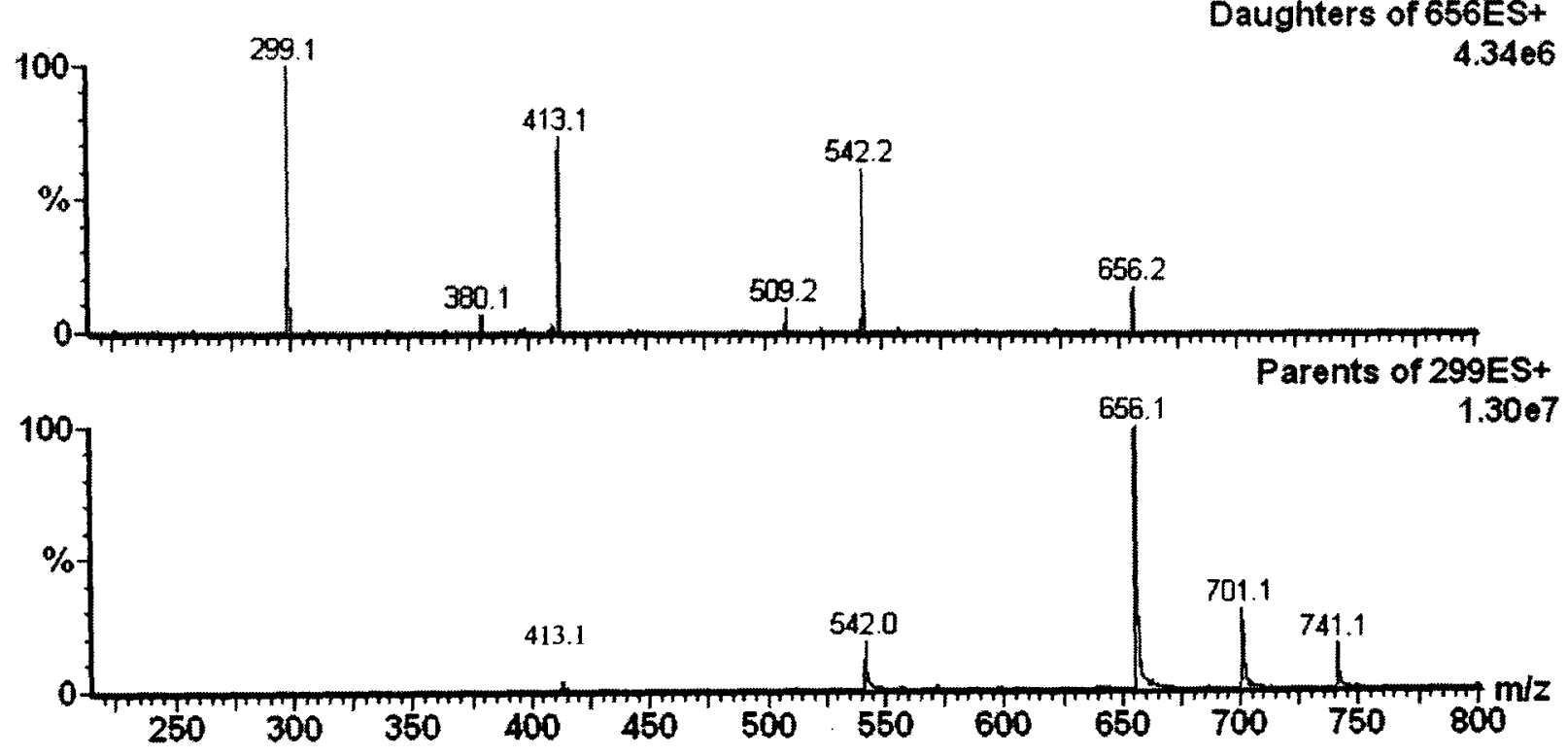


Figure 53 ESI-MS study of peptide $\mathrm{H}$ (53a) and the CID experiment of the peak of [peptide $\mathrm{H}+\mathrm{H}]^{+}(53 \mathrm{~b}$ and c)

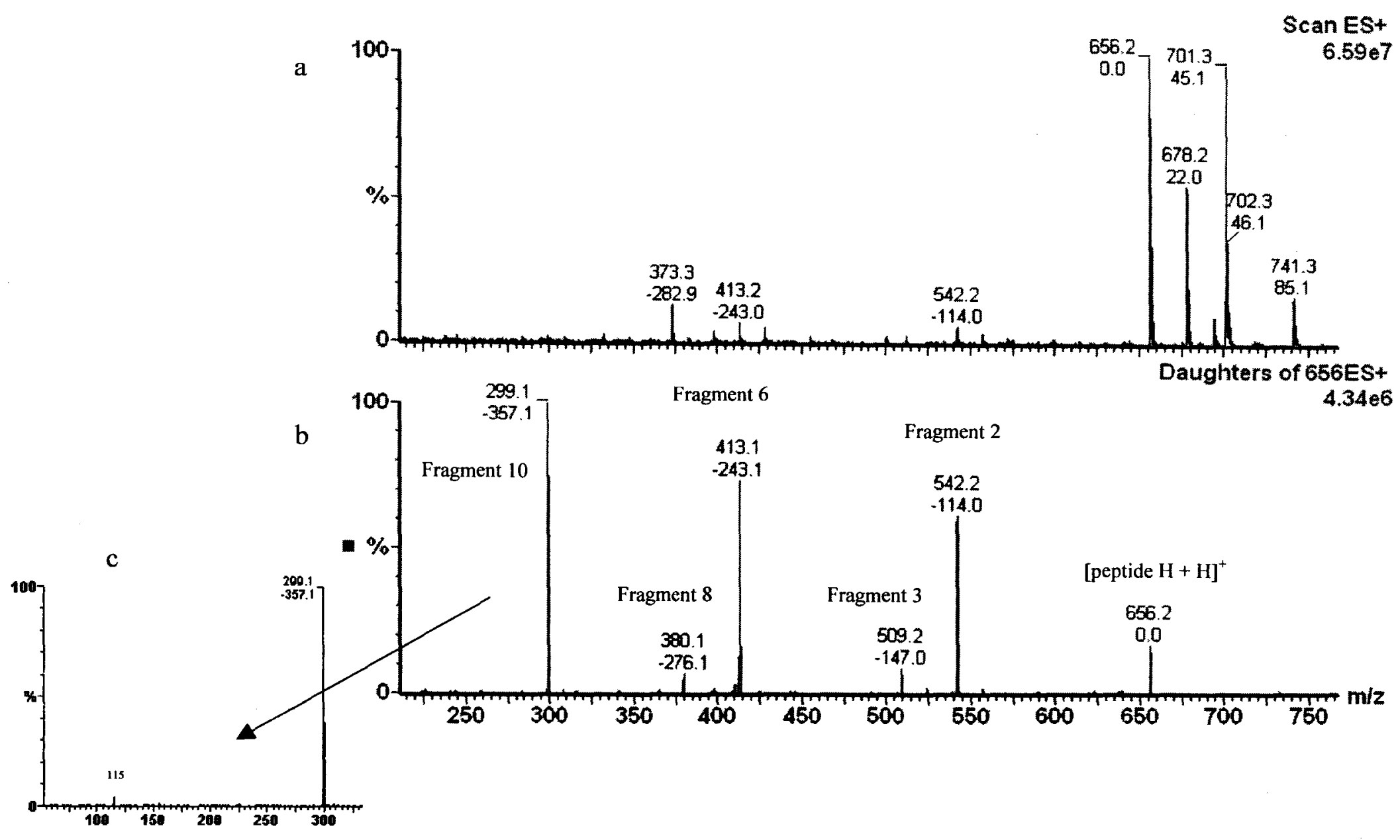


Figure 54 Proposed fragmentation path of peptide $\mathrm{H}$ to generate fragment 2 through C-terminal cleavage

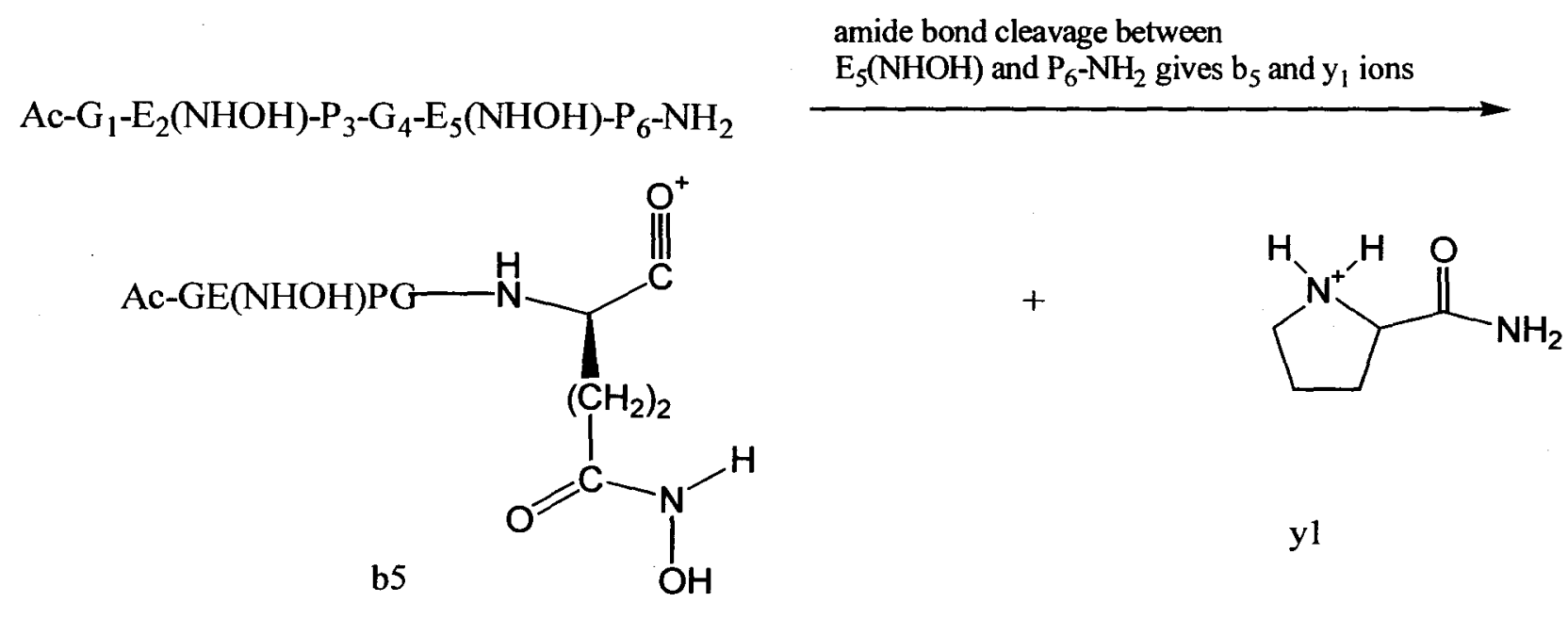

Fragment $2, \mathrm{~m} / \mathrm{z}=542$

Fragment $11, \mathrm{~m} / \mathrm{z}=115$

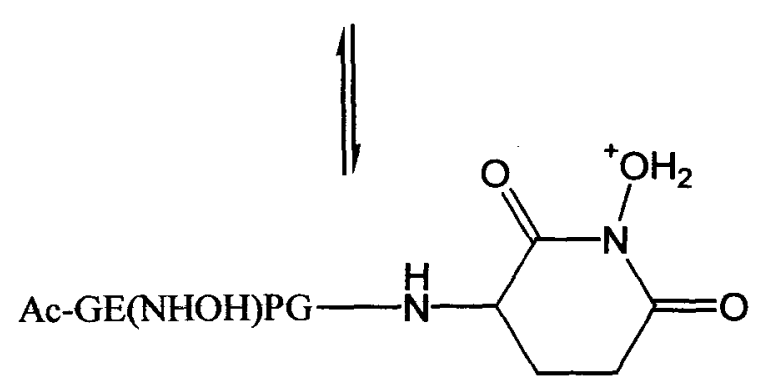

Fragment $2, \mathrm{~m} / \mathrm{z}=542$ 
Figure 55 Proposed fragmentation path of peptide $\mathrm{H}$ to generate fragment 3 through side chain cyclization

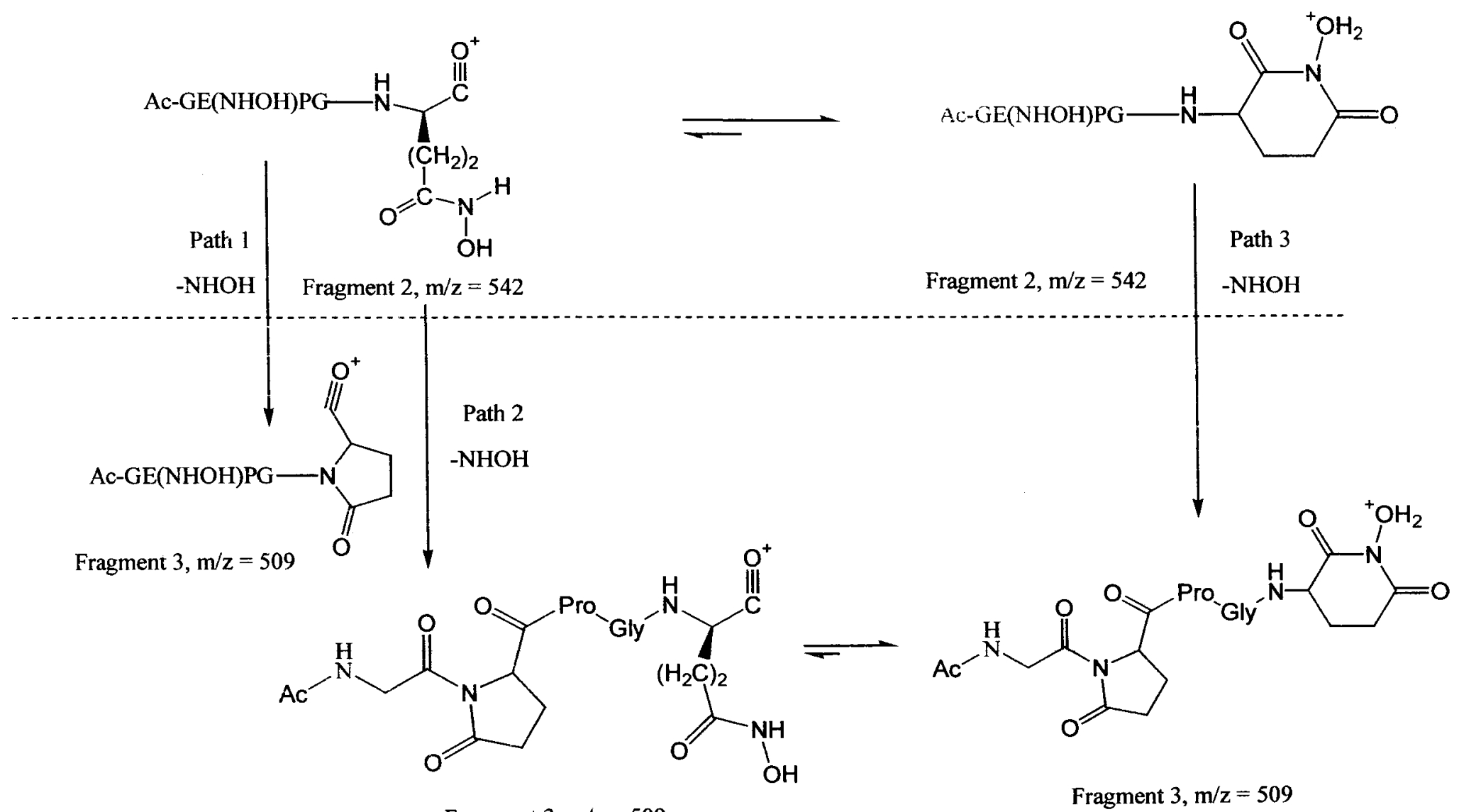

Fragment $3, \mathrm{~m} / \mathrm{z}=509$ 
Figure 56 Proposed fragmentation path of peptide $H$ to generate fragments 6 and 12 through cleavage between $\mathrm{E}_{2}(\mathrm{NHOH})$ and $\mathrm{P}_{3}$ and fragment 8 via fragment 6 side chain cyclization

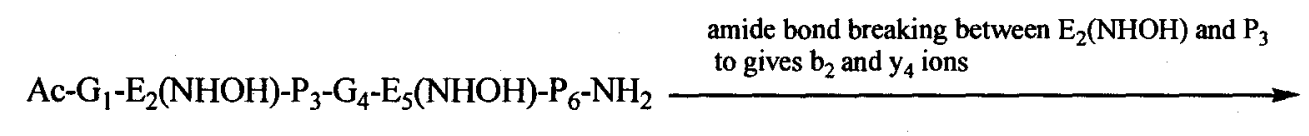

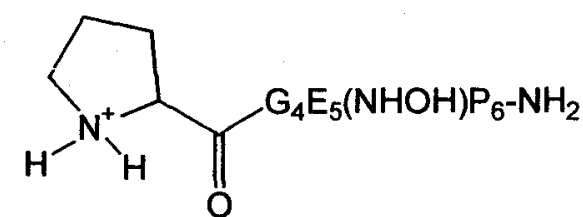

Fragment $6\left(y_{4}\right), m / z=413$

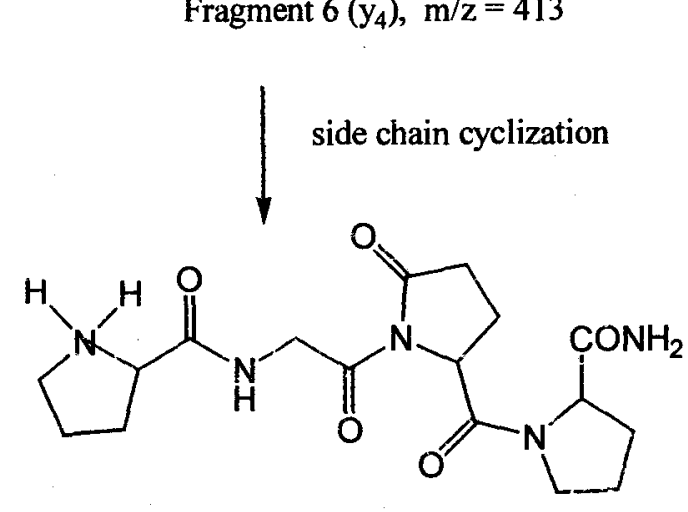

Fragment $8, m / z=380$

\section{Ac- $\mathrm{G}_{1}-\mathrm{E}_{2}^{+}(\mathrm{NHOH})$}

Fragment $12\left(b_{2}\right), m / z=244$

(1) 
All the observed daughter peaks of peptide $\mathrm{H}$ molecular ion peak $(\mathrm{m} / \mathrm{z}=656)$ except the peak with a mass of 299 have been assigned with respective fragment ions. In determining the structure of fragment $10(\mathrm{~m} / \mathrm{z}=299)$, we compared the fragment ions of peptide $E$ and peptide $H$ and discovered that fragment 10 in peptide $H$ could be the counterpart of double cleavage fragment PGE $(\mathrm{m} / \mathrm{z}=284)$ in peptide $\mathrm{E}$.

We observed that mass 299 could be mass 284 plus $15(\mathrm{NH})$, that fragment 10 $(\mathrm{m} / \mathrm{z}=299)$ must have the same amino acid composition as its glutamic acid analogue fragment ion with a mass of 284 , and have $\mathrm{CONHOH}$ group instead of $\mathrm{COOH}$ on glutamic acid side chain. Fragment ion with a mass of 284 was proposed as fragment ion $\left[\mathrm{P}_{3} \mathrm{G}_{4} \mathrm{E}_{5}\right]^{+}$in peptide E. Similarly, we deduced that fragment $10(\mathrm{~m} / \mathrm{z}=299)$ could be the product of double fragmentation including ion $\left[\mathrm{G}_{1} \mathrm{E}_{2}(\mathrm{NHOH}) \mathrm{P}_{3}\right]^{+},\left[\mathrm{E}_{2}(\mathrm{NHOH}) \mathrm{P}_{3} \mathrm{G}_{4}\right]^{+}$, $\left[\mathrm{P}_{3} \mathrm{G}_{4} \mathrm{E}_{5}(\mathrm{NHOH})\right]^{+},\left[\mathrm{G}_{4} \mathrm{E}_{5}(\mathrm{NHOH}) \mathrm{P}_{6}\right]^{+}$and $\left[\mathrm{CH}_{3} \mathrm{CO}-\mathrm{E}_{5}(\mathrm{NHOH}) \mathrm{P}_{6}-\mathrm{NH}_{2}\right]^{+}$the C-terminal residue after $\mathrm{Gly}_{4} \mathrm{~N}-\mathrm{C}$ bond cleavage. All of these fragments have the desired mass $(\mathrm{m} / \mathrm{z}=299)$.

The precursor (parent)-ion MS/MS was utilized in tracking the parent peaks of the defined fragment peak. Fragments with masses of 413, 542, 656, 701 and 741 were identified as the parent peaks of the ion with a mass of 299 (Figure 52, bottom spectrum). Fragments with the masses of 701 and 740 could be the peptide E metal adducts, which existed in the parent peptide sample, and will be discussed in detail. The fact that ion $\mathrm{P}_{3}{ }^{+} \mathrm{G}_{4} \mathrm{E}_{5}(\mathrm{NHOH}) \mathrm{P}_{6}$ (Fragment $\left.6, \mathrm{~m} / \mathrm{z}=413\right)$ could produce fragment $10(\mathrm{~m} / \mathrm{z} 299)$ is a clear evidence that fragment 10 should include C-terminal $\mathrm{Gly}_{4}$ and $\mathrm{Glu}_{5}(\mathrm{NHOH})$ in the tripeptide sequence. Therefore, we can eliminate the possibility of tripeptides $\mathrm{G}_{1} \mathrm{E}_{2}(\mathrm{NHOH}) \mathrm{P}_{3}$ and $\mathrm{E}_{2}(\mathrm{NHOH}) \mathrm{P}_{3} \mathrm{G}_{4}$ as fragment 10 . The identification of fragment 10 
among the structures $\mathrm{P}_{3} \mathrm{G}_{4} \mathrm{E}_{5}(\mathrm{NHOH}), \mathrm{G}_{4} \mathrm{E}_{5}(\mathrm{NHOH}) \mathrm{P}_{6}$ and $\mathrm{CH}_{3} \mathrm{CO}-\mathrm{E}_{5}(\mathrm{NHOH}) \mathrm{P}_{6}-\mathrm{NH}_{2}$ (Figure 57) was achieved through fragmentation study of fragment 10.

Figure 57 Structure of $\mathrm{PGE}(\mathrm{NHOH}), \mathrm{GE}(\mathrm{NHOH}) \mathrm{P}$ and $\mathrm{CH}_{3} \mathrm{CO}-\mathrm{E}(\mathrm{NHOH}) \mathrm{P}-\mathrm{NH}_{2}$<smiles>O=C(CC[C@H](C#[O+])NC(=O)CNC(=O)[C@@H]1CCCN1)NO</smiles>

$\mathrm{PGE}^{+}(\mathrm{NHOH})$<smiles>NCC(=O)N[C@@H](CCC(=O)NO)C(=O)N1CC[C@H](C=[Co])C1</smiles>

$\mathrm{GE}^{+}(\mathrm{NHOH}) \mathrm{P}$<smiles>CC(=O)N[C@@H](CCC(=O)NO)C(=O)N1CC[C@H](C(N)=O)C1</smiles>

${ }^{+} \mathrm{CH}_{3} \mathrm{CO}-\mathrm{E}(\mathrm{NHOH}) \mathrm{P}-\mathrm{NH}_{2}$

Among the daughter fragments of fragment 10 , the fragments corresponding to a proline immonium ion $(\mathrm{m} / \mathrm{z}=70)$ and a glutamic acid satellite ion $(\mathrm{m} / \mathrm{z}=145)$ were detected in Figure 58. We also observed a fragment with a mass of 126.9, representing the residue Pro- $\mathrm{N}^{+} \mathrm{H}=\mathrm{CH}_{2}$. Fragment ion Pro- $\mathrm{N}^{+} \mathrm{H}=\mathrm{CH}_{2}$ is the product of glycine $\mathrm{C}-\mathrm{C}$ bond cleavage in fragment 10 , which illustrated the existence of P-G sequence in fragment 10. Neither the double cleaved fragment $\mathrm{G}_{4} \mathrm{E}_{5}(\mathrm{NHOH}) \mathrm{P}_{6}$ nor the $\mathrm{N}-\mathrm{C}$ bond cleaved fragment $\mathrm{CH}_{3} \mathrm{CO}-\mathrm{E}_{5}(\mathrm{NHOH}) \mathrm{P}_{6}-\mathrm{NH}_{2}$ contains the sequence Pro-Gly, and only two kinds of tripeptide, $\mathrm{E}_{2}(\mathrm{NHOH}) \mathrm{P}_{3} \mathrm{G}_{4}$ and $\mathrm{P}_{3} \mathrm{G}_{4} \mathrm{E}_{5}(\mathrm{NHOH})$, can generate residue Pro$\mathrm{N}^{+} \mathrm{H}=\mathrm{CH}_{2}$. Since the sequence $\mathrm{G}_{4} \mathrm{E}_{5}(\mathrm{NHOH}) \mathrm{P}_{6}-\mathrm{NH}_{2}$ had already been eliminated as a possible structure by an earlier peak MS/MS study, we concluded that fragment 10 was 
$\mathrm{P}_{3} \mathrm{G}_{4} \mathrm{E}_{5}(\mathrm{NHOH})$. The MS/MS study of daughter peak of fragment 10 also supported this conclusion.

Fragment $\mathrm{P}_{3} \mathrm{G}_{4} \mathrm{E}_{5}(\mathrm{NHOH})$ could be obtained from the pathway described in Figure 59. After simultaneous amide bond cleavage between $\mathrm{Glu}_{2}-\mathrm{Pro}_{3}$ and $\mathrm{Glu}_{5}-\mathrm{Pro}_{6}$, fragment ions with a mass of 244 and 115 would have been generated in addition to fragment 10 . We detected the fragment ion with a mass of 115 by MS/MS (Figure 53, lower mass region); however, the peak at 244 was not among peptide $\mathrm{H}$ daughter peaks. Nonetheless, we observed a peak with the mass of 244 in low relative abundance among daughter peaks of the species with a mass of 701 (one of the peptide $\mathrm{H}$ adducts) (Figure 60 ), and we can assume that the fragment ion with a mass of 244 originated from peptide $\mathrm{H}$ as ion $\mathrm{b}_{2}$. Therefore, all fragment ions generated in this pathway were detected in peptide $\mathrm{H}$ and peptide $\mathrm{H}$ adduct MS/MS experiments, which could be used as a solid evidence to support the proposed structure of fragment 10 . This conclusion is consistent with the double fragmentation product $\mathrm{P}_{3} \mathrm{G}_{4} \mathrm{E}_{5}(\mathrm{~m} / \mathrm{z}=284)$ in peptide $\mathrm{E}$, and this unique double fragmentation has not been reported in any published literature to the best of our knowledge. The uniqueness of our system involving two proline residues in symmetric sequence can explain this significant double fragmentation. The amide bonds between prolines and glutamic acids were the most easily broken sites in peptide $\mathrm{E}$ and $\mathrm{H}$, which was demonstrated previously. Instead of being the unstable tertiary amide bond, the double cleavage could generate two more stable secondary amine residues, which could be the driving force of double cleavage for peptide $\mathrm{E}$ and $\mathrm{H}$. The similar double cleavage was also observed in the peptide $H$ metal complexes system, which will be discussed later. 
In conclusion, the amide bond between glutamic acid and proline was the most fragile bond in both peptide $\mathrm{E}$ and peptide $\mathrm{H}$, and the simultaneous cleavage of two of these bonds generated fragment $\mathrm{P}_{3} \mathrm{G}_{4} \mathrm{E}_{5}$ or $\mathrm{P}_{3} \mathrm{G}_{4} \mathrm{E}_{5}(\mathrm{NHOH})$ from peptide $\mathrm{E}$ or $\mathrm{H}$. It is worth noting that fragment $\mathrm{P}_{3} \mathrm{G}_{4} \mathrm{E}_{5}(\mathrm{NHOH})$ is the smallest detected and identified metal binding fragment for peptide $\mathrm{H}$ and bears only one metal binding site. Therefore, the detection of fragment 10 metal complex could enable us to locate the stronger metal binding site between $\mathrm{Glu}_{2}(\mathrm{NHOH})$ and $\mathrm{Glu}_{5}(\mathrm{NHOH})$.

Figure 58 Fragment $10(\mathrm{~m} / \mathrm{z}=299)$ in MS/MS Study

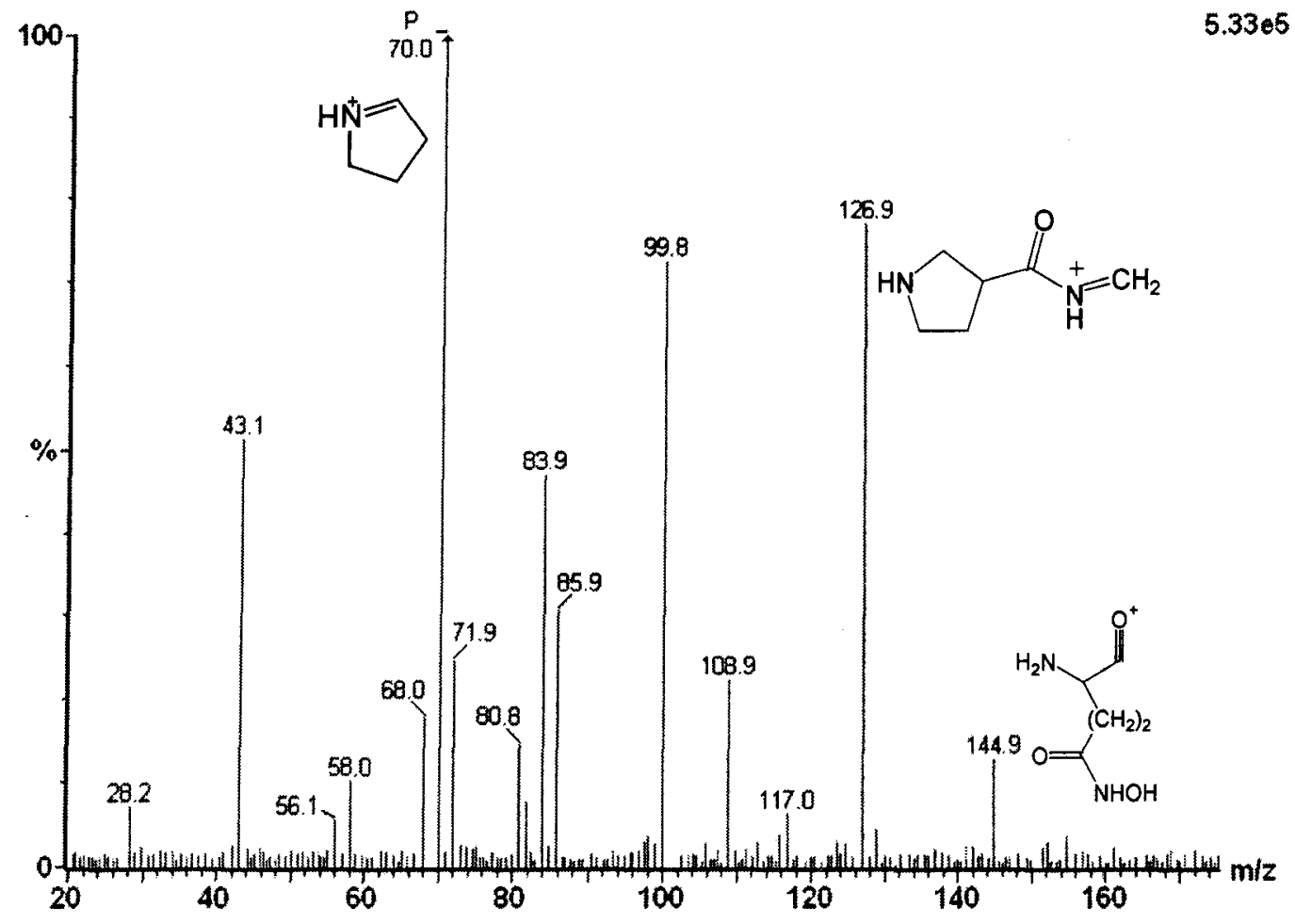


Figure 59 Proposed fragmentation path to give fragment ion with a mass of 299

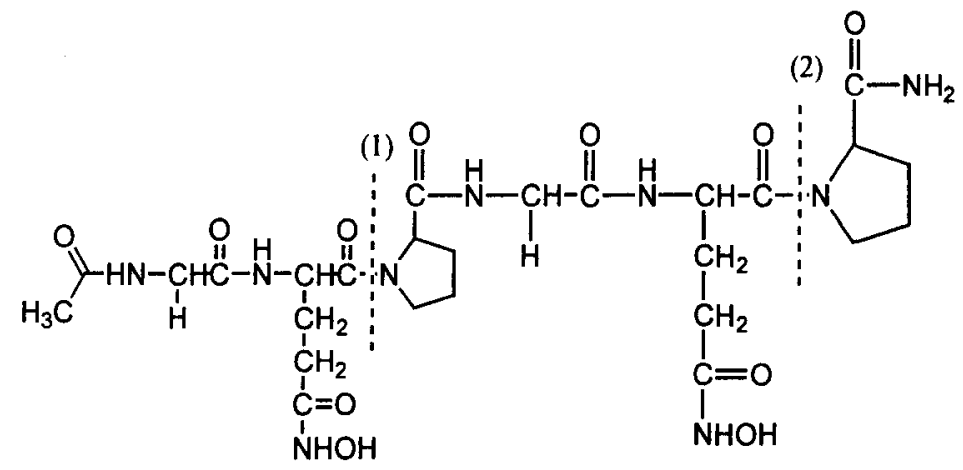

double cleavage at site 1 and site 2

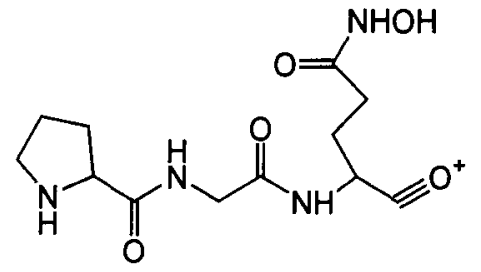

$\operatorname{PGE}^{+}(\mathrm{NHOH}), \mathrm{m} / \mathrm{z}=299$<smiles>CC(=O)NCC(=O)NC(C=[O+])CCC(=O)NO</smiles>

$\mathrm{Ac}-\mathrm{GE}^{+}(\mathrm{NHOH}), \mathrm{m} / \mathrm{z}=244$<smiles>NC(=O)C1CCC[NH+]1</smiles>

Pro- $\mathrm{NH}_{3}{ }^{+}, \mathrm{m} / \mathrm{z}=115$ 
Table 10 ESI-MS data from CID individual fragments of peptide $\mathrm{H}$

$\left(\mathrm{Ac}-\mathrm{Gly}_{1} \mathrm{Glu}_{2}(\mathrm{NHOH})_{\mathrm{d}} \mathrm{Pro}_{3} \mathrm{Gly}_{4} \mathrm{Glu}_{5}(\mathrm{NHOH})_{\mathrm{d}} \mathrm{Pro}_{6}-\mathrm{NH}_{2}\right)$,

along with the metal (Ni(II), $\mathrm{Zn}(\mathrm{II})$ and $\mathrm{Fe}(\mathrm{III}))$ adducts

\begin{tabular}{|c|c|c|c|c|c|}
\hline Fragment & $\begin{array}{c}\text { Mass } \\
\text { Difference }\end{array}$ & $\begin{array}{c}\text { Peptide } \mathrm{H}+\mathrm{H}^{\mathrm{a}} \\
(656)\end{array}$ & $\begin{array}{c}\text { Peptide } \mathrm{H}+\mathrm{Ni}^{2+b} \\
\text { (712) }\end{array}$ & $\begin{array}{c}\text { Peptide } \mathrm{H}+\mathrm{Zn}^{2+c} \\
\text { (718) }\end{array}$ & $\begin{array}{c}\text { Peptide } \mathrm{H}+\mathrm{Fe}^{3+d} \\
\text { (709) }\end{array}$ \\
\hline 1 & -33 & - & 679 & 685 & - \\
\hline 2 & -114 & 542 & 598 & 604 & 595 \\
\hline 3 & -147 & 509 & 565 & 571 & - \\
\hline 4 & -149 & - & - & - & 560 \\
\hline 5 & -189 & - & - & - & 520 \\
\hline 6 & -243 & 413 & 469 & 475 & 466 \\
\hline 7 & -275 & - & - & - & 434 \\
\hline 8 & -276 & 380 & 436 & 442 & - \\
\hline 9 & -291 & - & - & 427 & - \\
\hline 10 & -357 & 299 & 355 & 361 & 352 \\
\hline
\end{tabular}

a: reference Figure 53a; b: reference Figure 64b; c: reference Figure $65 \mathrm{~b}$; d: reference Figure 68 (bottom spectrum)

In the ESI-MS spectrum of peptide $\mathrm{H}$ (Figure 53, top spectrum), we found an unassigned peak with a mass of 701 detected with significant height. To verify that the ion with a mass of 701 originated from peptide $\mathrm{H}$, we performed a MS/MS study of peak 701 and found its fragment peaks (Figure 60) are in almost the same pattern as the daughter peaks of 656 (Figure 53, bottom spectrum). Thus, the peptide species with a mass of 701 was in the same peptide sequence as peptide $\mathrm{H}$. We first proposed that this peptide species should contain peptide $H$ adducted with two sodium ions (structure 1 in Figure 61), which has the correct mass but one more charge and did not agree with $\mathrm{m} / \mathrm{z}$ 
equaling of 701 . We also suggested the structure 2 with the deprotonated $\mathrm{NHOH}$ group and the peptide $\mathrm{H}$ sodium complex bearing an overall positive charge of one but with a mass of 700 (Figure 61). Therefore, the structure of the species with $\mathrm{m} / \mathrm{z}=701$ is still unclear.

Figure 60 CID study of molecular ion $(\mathrm{m} / \mathrm{z}=701)$

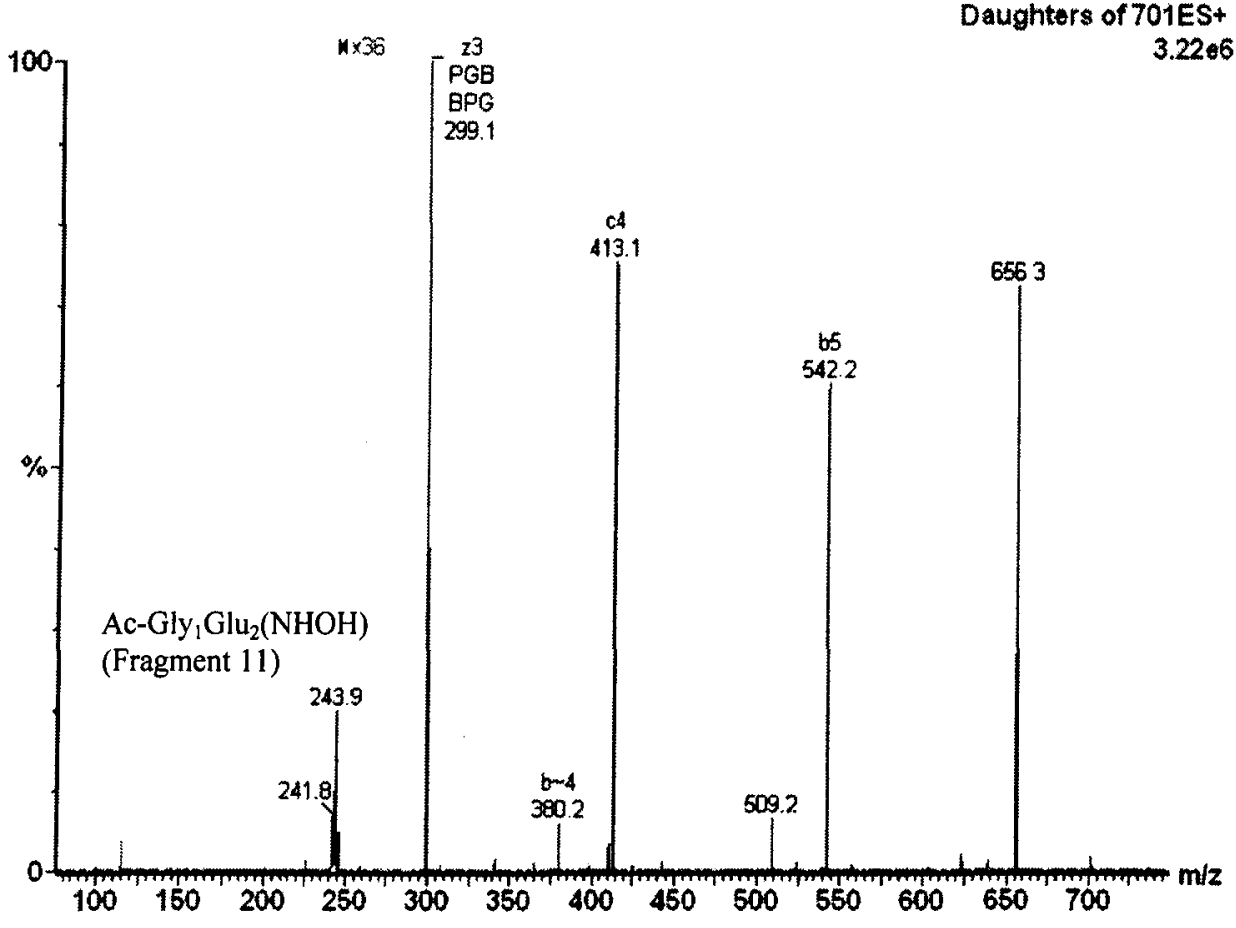

Figure 61 Possible structures of the molecular ion with a mass of 701

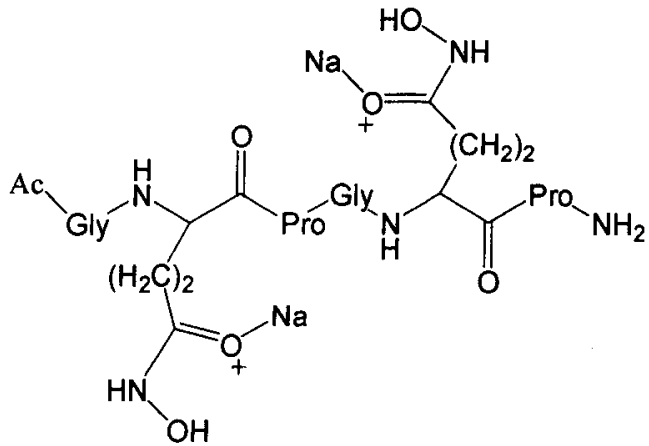

Structure 1

$$
\mathrm{C}_{26} \mathrm{H}_{41} \mathrm{~N}_{9} \mathrm{Na}_{2} \mathrm{O}_{11}{ }^{2+}
$$

Calculated Mass: 701.27

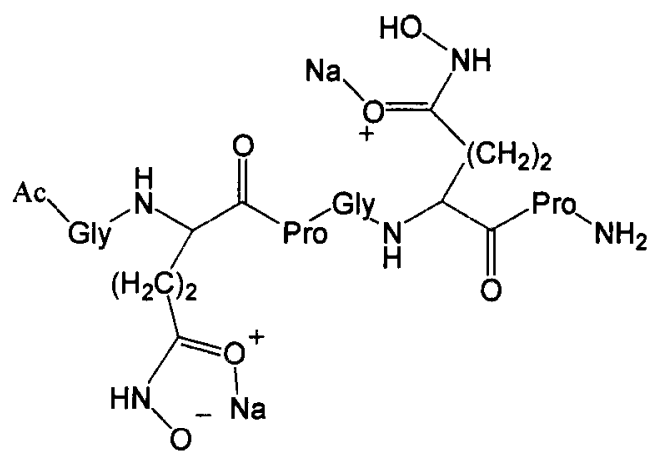

Structure 2

$$
\mathrm{C}_{26} \mathrm{H}_{40} \mathrm{~N}_{9} \mathrm{Na}_{2} \mathrm{O}_{11}{ }^{+}
$$

Calculated Mass: 700.26 


\section{Peptide $\mathrm{H} \cdot$ Metal Adducts Fragmentation}

Next we studied the peptide metal complex fragmentation by ESI-MS to locate the metal binding site of the hydroxamate peptide (Figure $64-66$ ). L was used to refer the free ligand hydroxamic acid peptide $\mathrm{H}$, and $\mathrm{M}$ referred to divalent cation $\mathrm{Ni}(\mathrm{II})$ or $\mathrm{Zn}(\mathrm{II})$.

Divalent cation nickel and zinc provided similar pattern of fragments in CID experiments. Hydroxamate peptide $\mathrm{H}$ has two metal binding sites, and both glutamic acid hydroxamate side chains could be deprotonated and come toward to each other to form a tetradentate binding pocket to hold the divalent cation $\left(\left[\mathrm{L}+\mathrm{Ni}^{2+}-\mathrm{H}^{+}\right]^{+}(\mathrm{m} / \mathrm{z}=712)\right.$ and $\left.\left[\mathrm{L}+\mathrm{Zn}^{2+}-\mathrm{H}^{+}\right]^{+}(\mathrm{m} / \mathrm{z}=718)\right)$ (Figure 62). However, one arm may have the stronger binding of the metal, which will be discussed later.

In peptide $\mathrm{H}$ metal adducts fragmentation routes, the $\mathrm{C}$-terminal cleavage of Pro$\mathrm{NH}_{2}$ group could give fragment $2 \cdot \mathrm{M}^{2+}$ ions (Figure 62). Upon ionization one hydroxamate group underwent self-cyclization to lose the $\mathrm{NHOH}$ metal chelator group, and only one hydroxamic acid group remained as bidentate ligand donor towards the divalent cation, the binding mode of which is depicted as fragment $3 \cdot \mathrm{Ni}$ (II) or $\mathrm{Zn}$ (II) complexes (Figure 62).

As mentioned before, the peptide chain of free peptide $\mathrm{H}$ could have cleaved between $\mathrm{Glu}_{2}(\mathrm{NHOH})$ and $\mathrm{Pro}_{3}$ and provided the sequence $\left[\mathrm{Pro}_{3}-\mathrm{Glu}_{4}(\mathrm{NHOH})-\mathrm{Gly}_{5}-\right.$ Pro $\left.6-\mathrm{NH}_{2}\right]^{+}$(fragment $6(\mathrm{~m} / \mathrm{z}=413)$ ) (Figure 64 , spectrum 3). In the case of the peptide metal complex, peaks at 469 (Figure 64, spectrum 2) and 475 (Figure 65 spectrum 2) are the fragment $6 \mathrm{Pro}_{3}-\mathrm{Glu}_{4}(\mathrm{NHOH})-\mathrm{Gly}_{5}-\mathrm{Pro}_{6}-\mathrm{NH}_{2}$ binding with $\mathrm{Ni}^{2+}$ and $\mathrm{Zn}^{2+}$ separately. Since the N-terminal fragment Ac-Gly $-\mathrm{Glu}_{2}(\mathrm{NHOH})(\mathrm{m} / \mathrm{z}=244)$ did not show up as 
adducts with metal ions in the CID experiment of peptide $\mathrm{H}$ nickel or zinc complexes, we concluded that after the amide bond scission, the metal stayed with $\mathrm{C}$ terminal peptide fragment instead of $\mathrm{N}$ terminal peptide fragment. This result suggested that $\mathrm{Ni}(\mathrm{II})$ and $\mathrm{Zn}(\mathrm{II})$ bind $\mathrm{C}$-terminal $\mathrm{Glu}_{5}(\mathrm{NHOH})$ more tightly than $\mathrm{N}$-terminal $\mathrm{Glu}_{2}(\mathrm{NHOH})$. The double fragmentation of peptide $\mathrm{H} \cdot \mathrm{Zn}(\mathrm{II})$ or $\mathrm{Ni}(\mathrm{II})$ complexes was observed in the same mode of free ligand peptide $\mathrm{H}$. The detection of fragment $10\left(\mathrm{P}_{3} \mathrm{G}_{4} \mathrm{E}_{5}(\mathrm{NHOH})\right) \cdot \mathrm{M}(\mathrm{II})$ complexes is a clear evidence that the $\mathrm{C}$-terminal metal binding site has stronger metal binding capability than the $\mathrm{N}$-terminal metal binding site (Figure 63). Fragment 8 could be generated through side chain cyclization of fragment 6 ; however, due to the unavailability of hydroxamic acid side chains, we could not determine the metal binding mode of fragment $8 \cdot \mathrm{M}(\mathrm{II})$ complex. The fragment with a mass of 427 was observed as one of the peptide $\mathrm{H} \cdot \mathrm{Zn}$ (II) complex daughter peaks, and the assignment of this peak is still under investigation.

The coordination structure of the peptide $\mathrm{H}$ fragment ion adducting with metal complexes is not well understood in our study. We proposed that the zinc and nickel in these fragment metal complexes would retain the same tetrahedron coordination geometry that solution phase metal possesses. In peptide $\mathrm{H}$ and fragment 2 metal complexes, $\mathrm{M}(\mathrm{II})$ binds with two bidentate hydroxamate chelators to form the fourcoordinated metal complex (Figure 62). Since fragments 1, 3,6 and 10 only have one hydroxamate metal chelator, $\mathrm{Ni}$ (II) and $\mathrm{Zn}$ (II) have to bind two more ligands to satisfy a tetrahedron geometry. The vacant coordination site of $\mathrm{Ni}$ and $\mathrm{Zn}$ metal could be occupied by solvent molecules, which were eliminated in the ionization process in gas phase and gave only the mass of a peptide fragment and a metal ion. Alternatively, other functional 
groups besides the hydroxamic acid side chain could coordinate the central metal (zinc or nickel) in these fragments (fragment 1,3,6 and 10) to provide a four-coordinate metalligand complex, and the details of the structure remained unclear. Overall the peptide $\mathrm{H}$. $\mathrm{M}(\mathrm{II})$ complexes (M: Ni(II) and $\mathrm{Zn}(\mathrm{II})$ ) experienced similar fragmentation processes to free peptide $\mathrm{H}$. Although only one hydroxamate metal binding site remained in the ligand, one hydroxamate group still functioned as the potent chelator in binding divalent cation $\mathrm{Zn}(\mathrm{II})$ and $\mathrm{Ni}(\mathrm{II})$. 
Figure 62 Proposed fragmentation route for the peptide H M(II) complex (L: free peptide H, M: Ni or Zn)

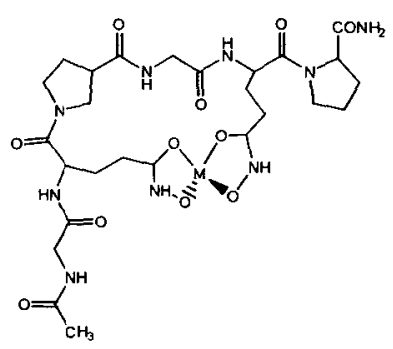

Peptide $\mathrm{H} \cdot \mathrm{M}(\mathrm{II})$

$\left[\mathrm{LM}^{2+}-\mathrm{H}^{+}\right](\mathrm{m} / \mathrm{z}=712$ or 718$)$

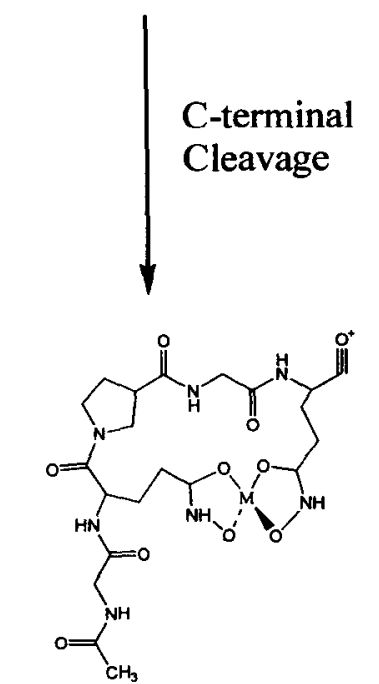

Side Chain Cyclization

Fragment $2 \cdot M(\mathrm{II}), \mathrm{m} / \mathrm{z}=598$ or 604
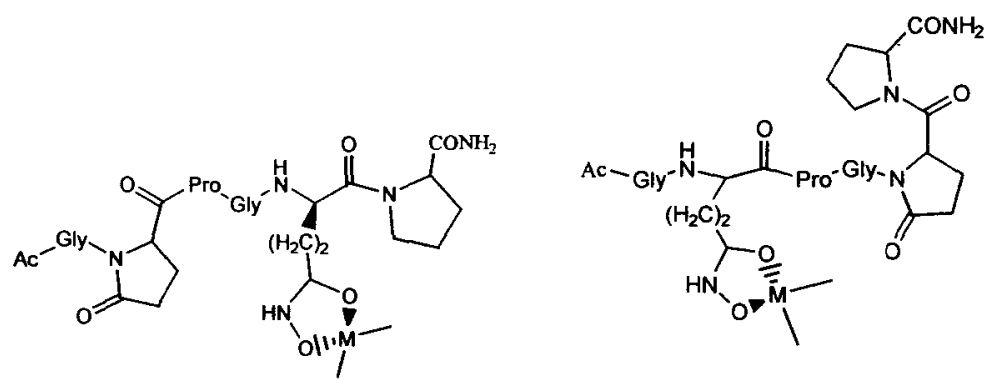

Fragment $1 \cdot M($ II), $(\mathrm{m} / \mathrm{z}=679$ or 685$)$

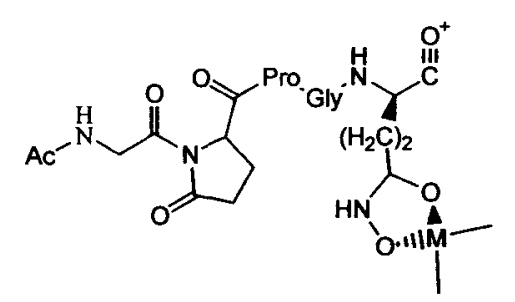

Fragment $3 \cdot M$ (II) $(\mathrm{m} / \mathrm{z}=565$ or 571$)$ 
Figure 63 Continued Proposed Fragmentation route for the peptide $H \cdot M(I I)$ complex (M: Ni or $\mathrm{Zn}$ )

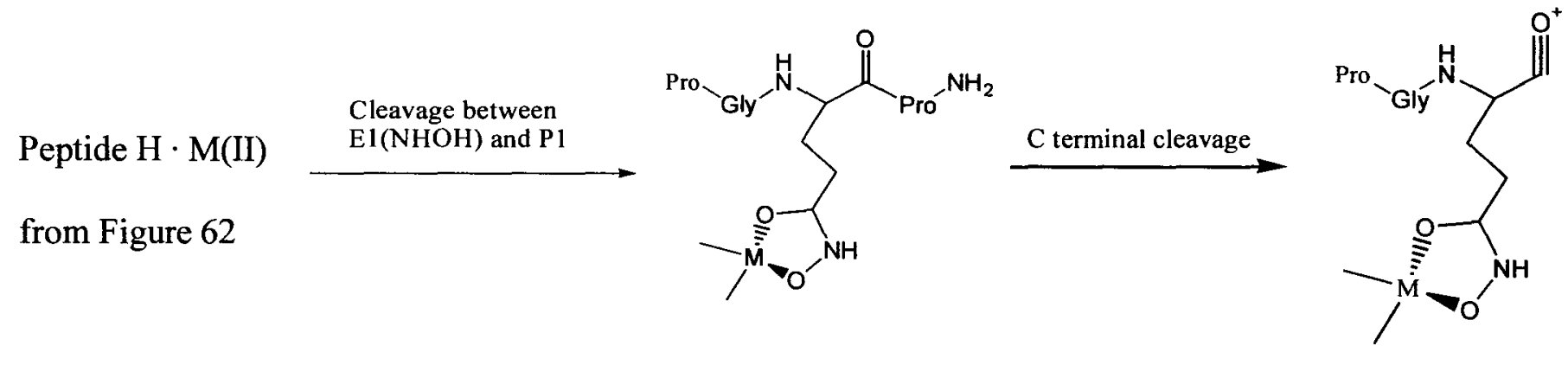

Fragment 6 .

Fragment $10 \cdot$

M(II)

M(II)
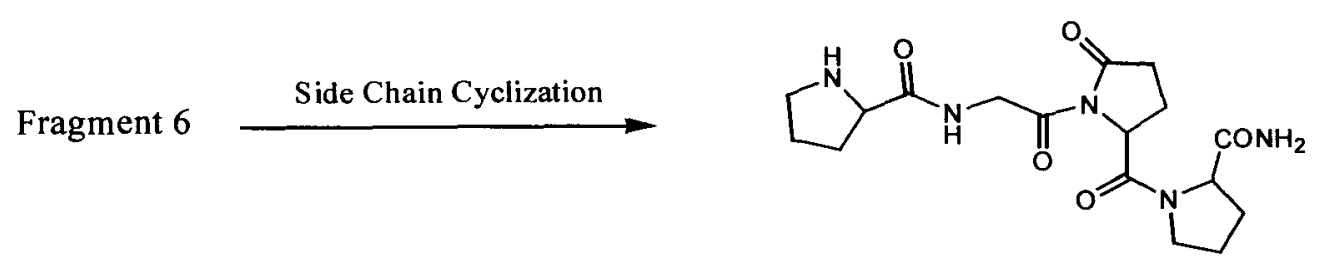

Fragment $8 \cdot M(I I), m / z=436$ or 442$)$

Proposed structure of Fragment 8

(Metal binding site is not determined) 
Figure 64 ESI-MS and MS/MS studies of peptide $\mathrm{H} \cdot \mathrm{Ni}(\mathrm{II})$ vs MS/MS study of free peptide $\mathrm{H}$ (64a: ESI-MS spectrum of peptide $\mathrm{H} \cdot \mathrm{Ni}(\mathrm{II}), 64 \mathrm{~b}$ : CID experiment of peptide $\mathrm{H} \cdot \mathrm{Ni}(\mathrm{II})$ molecular ion peak and 64c: CID experiment of peptide $\mathrm{H}$ molecular peak)
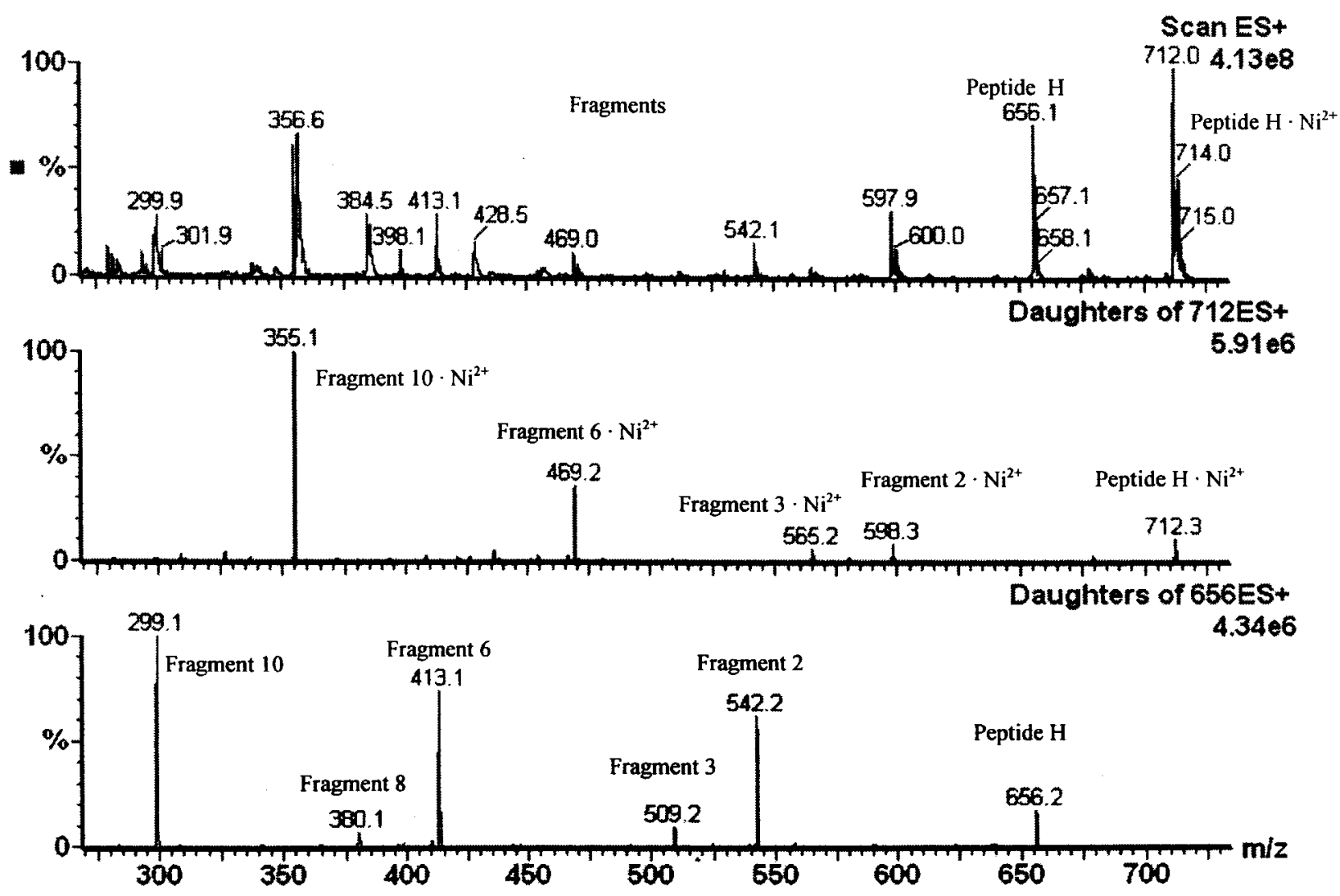
Figure 65 ESI-MS and MS/MS studies of peptide $\mathrm{H} \cdot \mathrm{Zn}$ (II)

(65a: ESI-MS spectrum of peptide $\mathrm{H} \cdot \mathrm{Zn}(\mathrm{II}), 65 \mathrm{~b}$ : CID experiment of peptide $\mathrm{H} \cdot \mathrm{Zn}(\mathrm{II})$ molecular ion peak and 65c: CID experiment of peptide $\mathrm{H}$ molecular peak)

$\mathbf{a}$

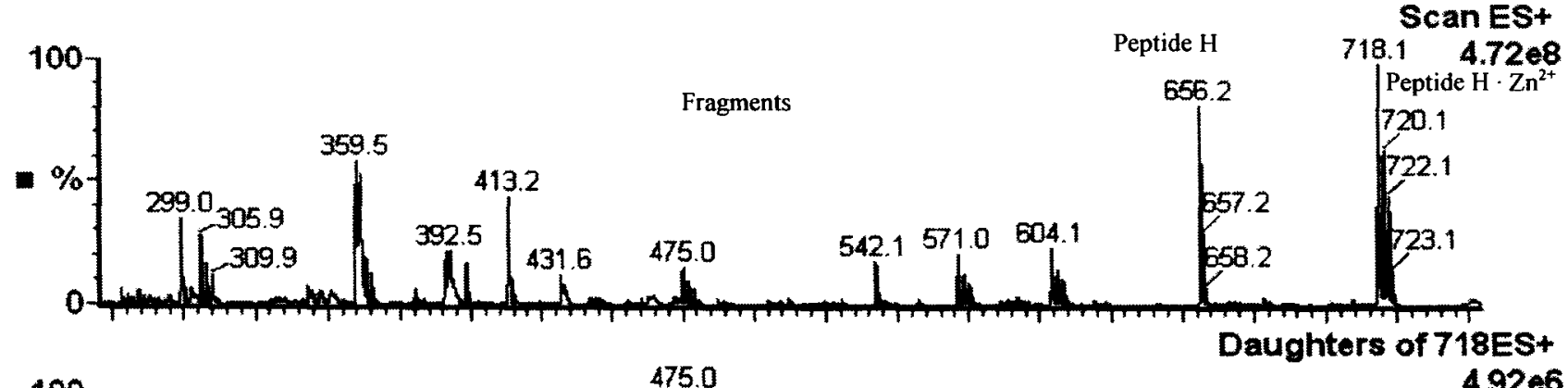

b

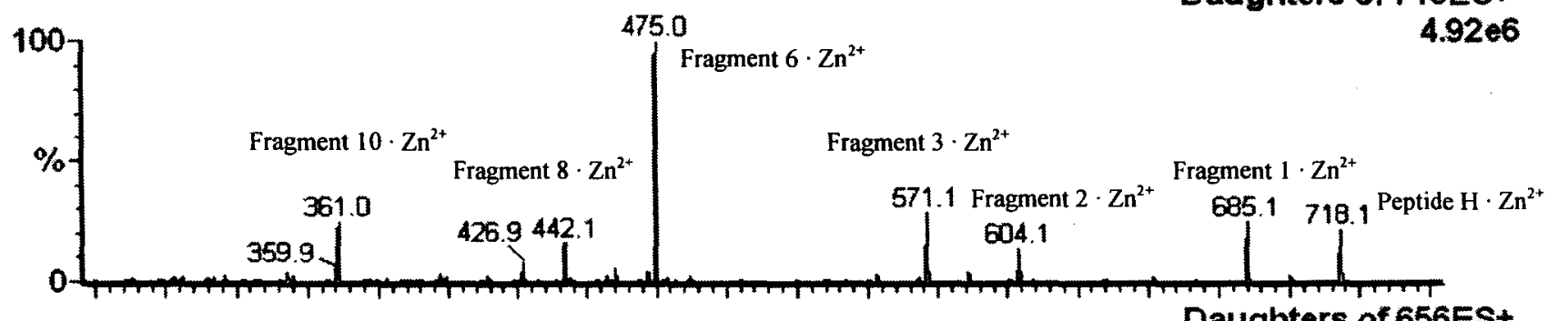

c

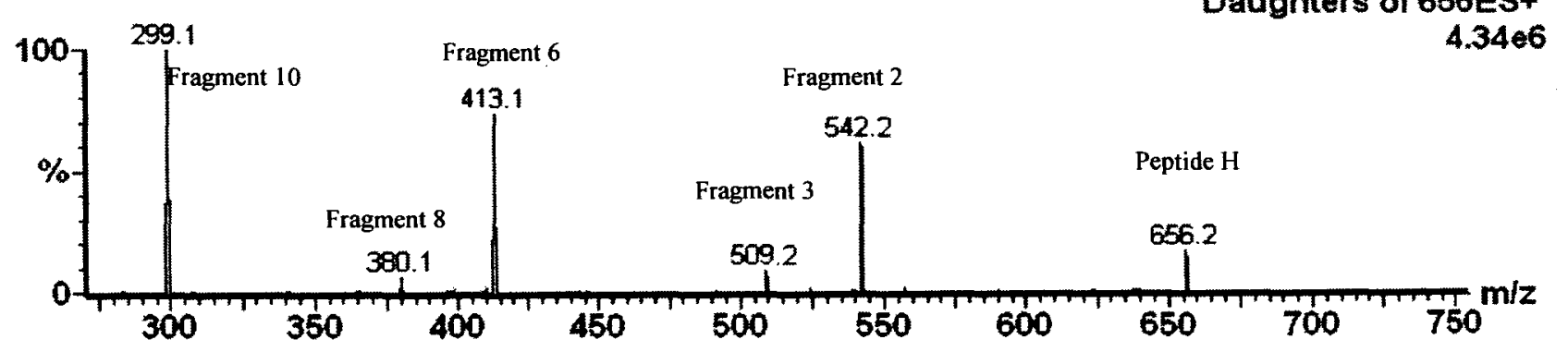


A single hydroxamic acid group behaves as a typical bidentate donor towards various metal ions, and the bihydroxamic acids in our system could function as tetradentate ligands to bind $\mathrm{Ni}$ and $\mathrm{Zn}$. Being a trivalent ion. $\mathrm{Fe}(\mathrm{III})$ usually participates in a six-coordinate complex with octahedral geometry. Hydroxamate type siderophores generally possess two or three hydroxamate functional groups, which are able to form stable hexacoordinate iron (III) complexes ( $\mathrm{FeL}$ or $\mathrm{Fe}_{2} \mathrm{~L}_{3}$, respectively). For example, alcalign is a 20 membered macrocylic dihydroxamate siderophore, which forms a 1: 1 ferric complex $\left(\mathrm{FeL}^{+}\right)$under acidic conditions and 2: 3 ferric complexes $\left(\mathrm{Fe}_{2} \mathrm{~L}_{3}\right)$ at and above neutral $\mathrm{pH}$ (Hou, 1998). The tetradentate ligand does not assume the preferred octahedral coordination geometry of $\mathrm{Fe}$ (III) by forming a simple 1:1 complex. In order to completely encapsulate the metal ion, a dihydroxamate siderophore must at minimum form a binuclear metal complex with a stoichiometry of $\mathrm{Fe}_{2} \mathrm{~L}_{3}$.

In this study, dihydroxamic acid peptide $H$ was mixed with ferric ion in a 1: 1 ratio in water/acetonitrile solution at $\mathrm{pH} 5$ and formed a $\mathrm{FeL}^{+}$complex, which was detected as an ion $\left[\mathrm{L} \cdot \mathrm{Fe}^{3+}-2 \mathrm{H}^{+}\right]^{+}(\mathrm{L}$ : peptide $\mathrm{H})$ with a mass of 709 in ESI-MS (Figure 66). The center Fe atom could octahedrally coordinate with two C-O oxygens, two N-O oxygens from peptide $\mathrm{H}$ and two solvent molecules (Figure 67). The two solvent molecules could be detached from the metal in the process of ionization; therefore, we just observed iron binding with peptide H complex in MS study. 
Figure 66 ESI-MS study of peptide $\mathrm{H} \cdot \mathrm{Fe}(\mathrm{III})$

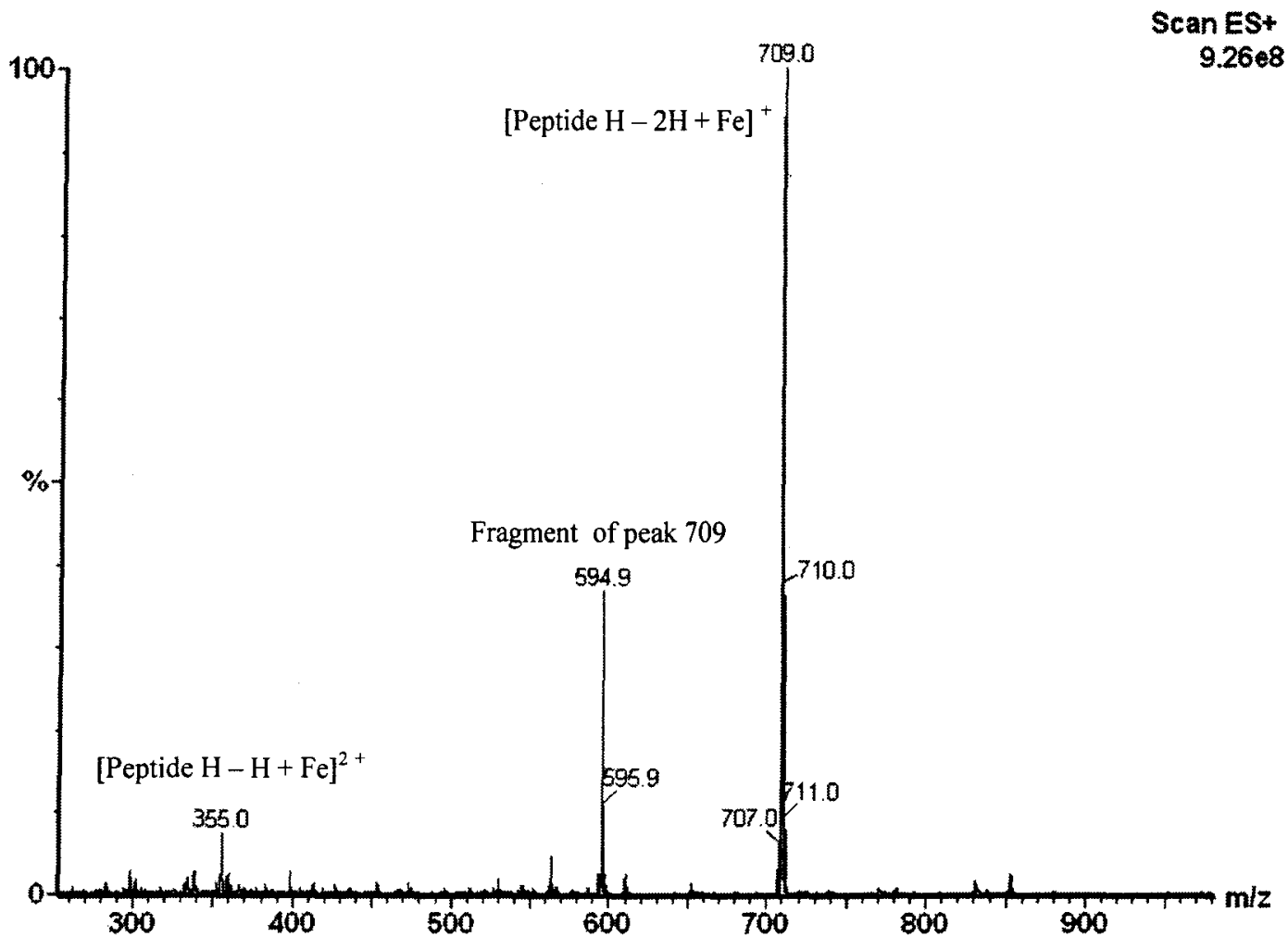

We also studied the peptide $\mathrm{H} \cdot \mathrm{Fe}(\mathrm{III})$ complex fragmentation process and found some similarities between peptide $\mathrm{H} \cdot \mathrm{Fe}(\mathrm{III})$ fragmentation route and peptide $\mathrm{H} \cdot \mathrm{Ni}(\mathrm{II})$ and peptide $\mathrm{H} \cdot \mathrm{Zn}(\mathrm{II})$ fragmentation pathes. For example, the C-terminal amino acid cleavage occurred in both the peptide $\mathrm{H} \cdot \mathrm{Fe}$ (III) complex (Figure 69) and the peptide $\mathrm{H}$. $\mathrm{Ni}(\mathrm{II}) / \mathrm{Zn}$ (II) complex (Figure 69 and Table 10). The amide bond cleavage between $\mathrm{Glu}_{2}(\mathrm{NHOH})$ and $\mathrm{Pro}_{3}$ was also observed in peptide $\mathrm{H}$ iron complex and provided fragment 6 iron adduct in an MS/MS study. In the complex $\mathrm{P}_{3} \mathrm{G}_{4} \mathrm{E}_{5}(\mathrm{NHOH}) \mathrm{P}_{6}-\mathrm{NH}_{2}$. $\mathrm{Fe}(\mathrm{III})(\mathrm{m} / \mathrm{z}=466)$, the metal iron stayed in the C-terminal peptide fragment, which demonstrates that the $\mathrm{C}$-terminal binding site $\mathrm{Glu}_{5}(\mathrm{NHOH})$ has the stronger ironchelating capability than the $\mathrm{N}$-terminal binding site $\mathrm{Glu}_{2}(\mathrm{NHOH})$. This observation is consistent with what we found in nickel and zinc complexes. The double fragmentation is 
represented by the complex molecular fragment $10 \cdot \mathrm{Fe}$ (III) (with a mass of 352 ) and shows that the C-terminal binding site is the major chelator in the dihydroxamate ligand peptide $\mathrm{H}$. However as it was shown in Figure 69, the fragment iron complexes coordination structure was not determined in our study. The vacant coordination site of the center $\mathrm{Fe}$ atom could be occupied by the solvent molecule in water/ acetonitrile solution before ionization with the octahedral geometry being lost in the gas phase to provide the complexes (Figure 69) and thus resulting in the complexes having partially encapsulate central iron atom.

Figure 67 Proposed structure of peptide $\mathrm{H} \cdot \mathrm{Fe}$ (III)

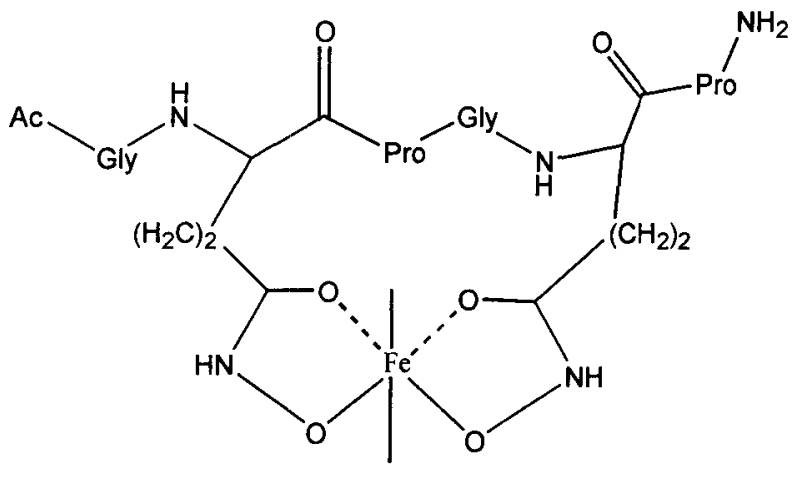

$\left[\mathrm{L} \cdot \mathrm{Fe}^{3+}-2 \mathrm{H}^{+}\right]^{+}(\mathrm{m} / \mathrm{z}=709)$

Among the daughter peaks of fragment 709 , the peaks at 560, 520 and 434 are remained unassigned. First, we confirmed that all of the peaks are peptide fragments 
binding with Fe(III) by comparing the MS/MS spectra of complex with a mass of 709 and a mass of 707 (one of the isotopes of the peptide $\mathrm{H} \cdot \mathrm{Fe}(\mathrm{III})$ adduct) (Figure 68). All the counterparts of peaks at 560,520 and 434 in MS/MS study of the complex with a mass of 709 were observed with less than two masses among daughter peaks of 707 . We tentatively assigned the fragment with a mass of 434 as fragment 8 adducting with $\mathrm{Fe}(\mathrm{III})$, which has the formula $\mathrm{C}_{17} \mathrm{H}_{24} \mathrm{FeN}_{5} \mathrm{O}_{5}{ }^{2+}$ with the mass 434.11 (Figure 69). Obviously, this structure does not satisfy $\mathrm{m} / \mathrm{z}=434$ which was observed in MS/MS study.

Figure 68 M/MS study of the peak at $707 v s$ the peak at 709

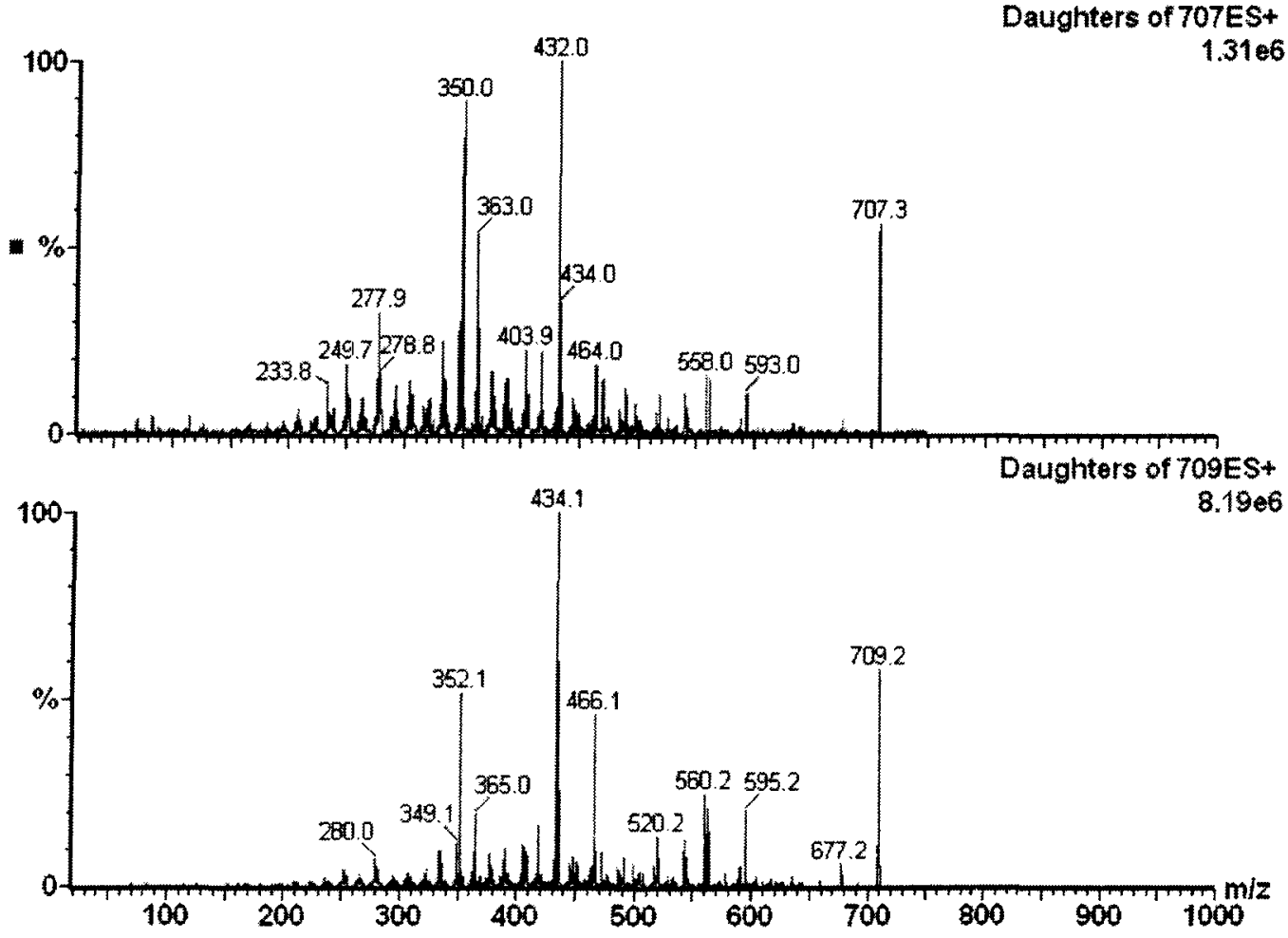


Figure 69 Proposed structure of peptide $\mathrm{H}(\mathrm{L}) \cdot \mathrm{Fe}^{3+}$ and the resulting fragments

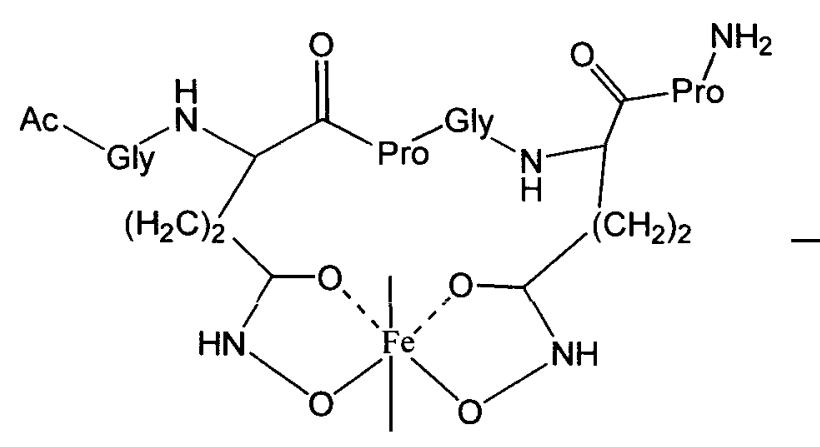

$\left[\mathrm{L} \cdot \mathrm{Fe}^{3+}-2 \mathrm{H}^{+}\right]^{+}(\mathrm{m} / \mathrm{z}=709)$

$\bar{\alpha}$

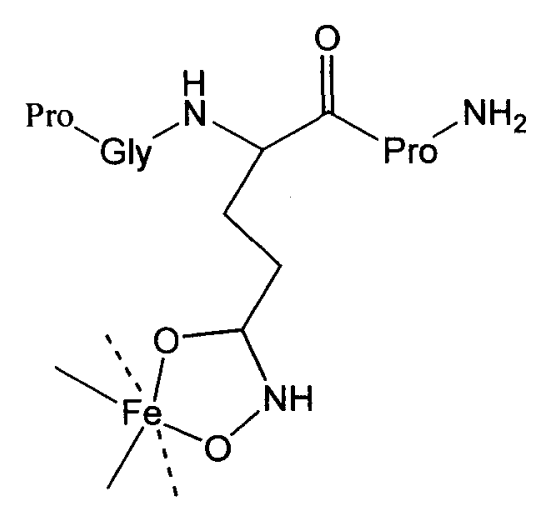

Fragment 6. $\mathrm{Fe}(\mathrm{III})$ $\mathrm{m} / \mathrm{z}=466$<smiles>CP1(C)(C)ON=C(CCC(C=[O+])NC(=O)CNC(=O)C2CCCN2)O1</smiles>

Fragment 10· $\mathrm{Fe}(\mathrm{III})$

$\mathrm{m} / \mathrm{z}=352$

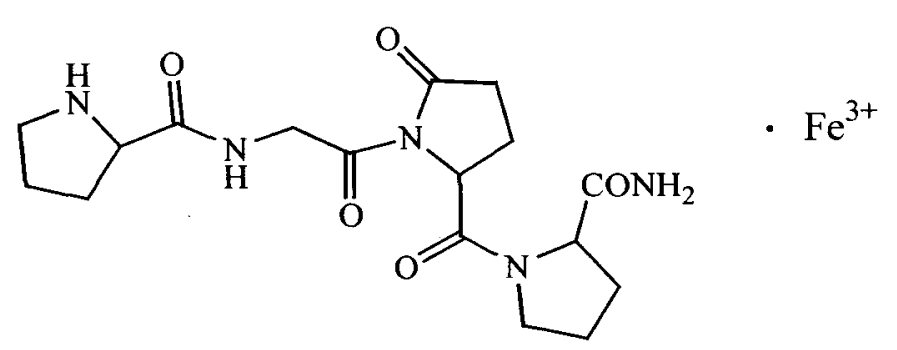

[Fragment $\left.8 \cdot \mathrm{Fe}^{3+}-2 \mathrm{H}^{+}\right]^{2+}$

$\mathrm{C}_{17} \mathrm{H}_{24} \mathrm{FeN}_{5} \mathrm{O}_{5}{ }^{2+}$

Calculated Mass: 434.11 


\section{Conclusion}

In this study we designed and synthesized two acetylated amidated symmetric hexapeptides with two carboxylic acids or two hydroxamate functional groups as metal chelators. The preparation was carried out by using solid phase peptide synthesis and the hydroxamate functional groups were introduced by condensing side chain acids with $\mathrm{O}$ benzylhydroxylamine. ESI-MS proved to be an efficient tool to study peptide metal selectivity, which could not be clearly interpreted in earlier MALDI-TOF MS experiments. An MS/MS study was used to locate the stronger metal binding site between the two metal chelating groups in one ligand.

In a peptide competitive metal binding study, we did not observe any significant preference of peptide $\mathrm{E}$ (diacid) towards cations $\mathrm{Fe}(\mathrm{III}), \mathrm{Ni}(\mathrm{II})$ and $\mathrm{Zn}$ (II) (Figure 43 a and e). However, metal selectivity studies of bihydroxamate peptide $\mathrm{H}$ demonstrated that the chelators were almost exclusively selective to $\mathrm{Fe}(\mathrm{III})$ in the presence of $\mathrm{Ni}(\mathrm{II})$ and $\mathrm{Zn}(\mathrm{II})$, and the selectivity was $\mathrm{pH}$ independent in the range of $\mathrm{pH} 2 \sim 5$ (Figure 4447).

In the ESI-MS spectra of peptide $\mathrm{H} \cdot \mathrm{Ni}(\mathrm{II})$ and peptide $\mathrm{H} \cdot \mathrm{Zn}(\mathrm{II})$, the free peptide $\mathrm{H}$ peak was observed with significant intensity. A large number of fragment ion peaks were also found in addition to the peptide $\mathrm{H}$ metal complex peak (Figure 64 and Figure 65). These fragments were generated upon ionization with a voltage between 4-5 $\mathrm{e}^{8}$ and belonged to daughter peaks of both free peptide $\mathrm{H}$ and peptide $\mathrm{H}$ metal complexes. A much simpler spectrum was obtained in the peptide $\mathrm{H} \cdot \mathrm{Fe}(\mathrm{III}) \mathrm{MS}$ study (Figure 66), since no free ligand peak was observed and only one fragment peak was detected in addition to the complex molecular ion peak. The $\mathrm{Fe}(\mathrm{III}) \cdot$ peptide $\mathrm{H}$ complex survived a

much stronger voltage $\left(9.26 \mathrm{e}^{8}\right)$ in the process of ionization than other complexes did. 
Therefore, the conclusion could be drawn that peptide $\mathrm{H}$ formed a much more stable complex with $\mathrm{Fe}^{3+}$ than with $\mathrm{Ni}^{2+}$ or $\mathrm{Zn}^{2+}$, and peptide $\mathrm{H}$ thus has a significant preference to $\mathrm{Fe}(\mathrm{III})$ compared to $\mathrm{Zn}(\mathrm{II})$ or $\mathrm{Ni}(\mathrm{II})$, as previously seen in the competitive metal binding studies.

By utilizing the ESI-MS/MS technique, the most fragile amide bonds in the hexapeptides peptide $\mathrm{E}$ and peptide $\mathrm{H}$ (free ligands) were determined to be located between glutamic acid and proline. These bond scissions provided C-terminal fragment (Ac-Gly-Glu-D-Pro-Gly-Glu ${ }^{+}$or $\quad$ Ac-Gly-Glu(NHOH)-D-Pro-Gly-Glu ${ }^{+}$), N-terminal fragment (D-Pro ${ }^{+}-\mathrm{Gly}-\mathrm{Glu}-\mathrm{D}-\mathrm{Pro}-\mathrm{NH}_{2}$ or $\mathrm{D}-\mathrm{Pro}^{+}-\mathrm{Gly}-\mathrm{Glu}(\mathrm{NHOH})-\mathrm{D}-\mathrm{Pro}-\mathrm{NH}_{2}$ ) and a double cleavage produced the fragment D-Pro-Gly-Glu ${ }^{+}$or D-Pro-Gly-Glu ${ }^{+}(\mathrm{NHOH})$ for peptide $\mathrm{E}$ and peptide $\mathrm{H}$ (Figure 50, 51, 56 and 59). Also, an intramolecular cyclization ($\mathrm{NHOH}$ ) involving the hydroxamate side chain was verified in an MS/MS study (Figure 52, Table 10).

Fragmentation of the hydroxamic acid containing peptide $\mathrm{H} \cdot \mathrm{Ni}(\mathrm{II})$ and peptide $\mathrm{H}$ - $\mathrm{Zn}$ (II) followed a similar pathway as the free ligand peptide $\mathrm{H}$, except that the intramolecular cyclization (-NHOH) was not always accompanied by bond scission (Figure 62, Table 10). We also proposed that the C-terminal Glu(NHOH) metal chelation strengthens the amide bond between $\mathrm{Glu}_{5}-\mathrm{Pro}_{6}$ to some extent; and therefore, $\mathrm{N}$-terminal glutamic hydroxamate side chain cyclization occurs before $\mathrm{Glu}_{5}-\mathrm{Pro}_{6}$ bond cleavage. In the ESI-MS spectra of peptide $\mathrm{H} \cdot \mathrm{Ni}(\mathrm{II})$ and peptide $\mathrm{H} \cdot \mathrm{Zn}(\mathrm{II})$, an $\mathrm{N}$-terminal fragment and a double cleavage fragment were observed once again in concern with metal binding. Since only one metal binding site, $\mathrm{Glu}_{5}(\mathrm{NHOH})$, exists in these fragments, this result demonstrated that the C-terminal binding site $\left(\mathrm{Glu}_{5}(\mathrm{NHOH})\right)$ has a stronger chelation 
capability than the $\mathrm{N}$ terminal $\left(\mathrm{Glu}_{2}(\mathrm{NHOH})\right)$ metal binding site in peptide $\mathrm{H}$, when this ligand binds to $\mathrm{Ni}(\mathrm{II})$ or $\mathrm{Zn}(\mathrm{II})$.

The peptide $\mathrm{H} \cdot \mathrm{Fe}(\mathrm{III})$ complex showed a more complicated fragmentation pathway. Only some elements of the fragmentation of the complex could be explained in this study. The Glu-Pro amide bond scission was observed to provide a C-terminal fragment and an $\mathrm{N}$-terminal fragment, as well as the double cleavage fragment. This observation enabled us to locate the stronger iron chelator site as we have seen for nickel and zinc. However, no hydroxamate side chain cyclization was observed with the iron complex, which can be explained by the fact that the hydroxamate ligand binding Fe(III) complex is more stable than the divalent ions adducts.

In general, it is clear that the hydroxamate peptide has a very high selectivity for $\mathrm{Fe}(\mathrm{III})$ over $\mathrm{Zn}(\mathrm{II})$ and $\mathrm{Ni}(\mathrm{II})$, and the potential of the peptide to strongly bind other trivalent metal ions besides iron can be studied in future work. The symmetry of the model peptide chain used for these studies led to some difficulties in fragment sequence determination and metal binding site location. This problem could be overcomed by introducing isotopically labeled amino acids to assist in the analysis if the fragment from multiple metal binding sites is found in the same ligand.

\section{E Experimental Section}

Instruments and materials

The $\mathrm{N}^{\alpha}$-Boc-protected amino acids, $\mathrm{N}^{\alpha}$-Fmoc-protected amino acids and BOP coupling reagent were purchased from Advanced Chem Tech (Louisville, KY). HOBt was from Quantum Technologies and TFA was from Halocarbon Products Corp. The 
pMBHA resin (1.2meq/g) was a gift from Peptides International (Louisville). DMF was the solvent used in coupling reaction and was purchased from Fisher and distilled by standard protocol before usage.

The RP-HPLC analysis was performed on a Hitachi $655 \mathrm{~A}$ system, which was equipped with L-5000 controller and D-200 integrator. A Vydac 4.6-250mm C18 column was used for analytical HPLC with detection at $220 \mathrm{~nm}$. The peptides were eluted with a linear acetonitrile/water gradient with a constant concentration of TFA $(0.05 \% \mathrm{v} / \mathrm{v})$ and the separations were monitored by UV detector set at $220 \mathrm{~nm}$. HF cleavage of peptides from resin was carried out in a Kel-F HF apparatus (Peptide Institute, Osaka). The sequence of the peptides was verified by MALDI-TOF MS. Peptide metal binding experiments were carried out using both matrix-assisted laser desorption ionization time of flight (MALDI-TOF) spectrometer (Voyager-DE ${ }^{\mathrm{TM}}$ Pro) and a micromass quartoLCZ triple-quadrupole mass spectrometer (ESI-MS).

\section{Synthesis of Ac-Gly-Glu-D-Pro-Gly-Glu-D-Pro-NH2}

(1) Preparation of Boc-D-Pro-MBHA resin (3)

Prior to the addition of the first amino acid to the solid support, the MBHA resin (3 g, $3.6 \mathrm{mmol}$ ) was swelled in $20 \mathrm{~mL}$ DIEA/DMF (1:9) solvent for $30 \mathrm{~min}$. DMF was then filtered off. An anhydrous DMF solution (25 mL) of Boc-D-Pro-OH (3.10 g, 14.4 mmol), BOP (6.37 g, $14.4 \mathrm{mmol})$ and $\operatorname{HOBt}(1.95 \mathrm{~g}, 14.4 \mathrm{mmol})$ was charged with DIEA $(5 \mathrm{~mL}, 28.8 \mathrm{mmol})$. The mixture was introduced to the pre-swollen resin in the reaction vessel and allowed to shake for $1 \mathrm{~h}$. Afterwards the solvent was removed, and the resin was washed with DMF $(3 \times 1 \mathrm{~min}), \mathrm{MeOH}(3 \times 1 \mathrm{~min})$ and DCM $(3 \times 1 \mathrm{~min})$. A 
ninhydrine (Kaiser test) showed the complete loading of Boc-D-Pro-OH to the resin and the resin ready for future coupling.

(2) Preparation of Gly-Glu-D-Pro-MBHA resin (4)

The entire batch of resin $3(1.2 \mathrm{meq} / \mathrm{g}$; approximate $3 \mathrm{~g})$ was treated with $30 \mathrm{~mL}$ $50 \%$ TFA (TFA/ $\mathrm{CH}_{2} \mathrm{Cl}_{2} /$ anisole: $50 / 45 / 5$ ) for $30 \mathrm{~min}$ to deprotect the Boc group. Next Boc-Glu(OBn)-OH (4.86 g, $337.4 \mathrm{mmol})$ and Boc-Gly-OH (2.52 g, $175.2 \mathrm{mmol})$ were coupled to the resin by following the traditional Boc cycle (Chapter 1 Table 5). The $\mathrm{N}-$ terminal protecting group (tert-butyloxycarbonyl group) on glycine was removed by TFA again and the resin was dried and split for further reaction.

(3) Preparation of Ac-Gly-Glu-D-Pro-Gly-Glu-D-Pro-MBHA resin (5)

A portion of the tripeptide-resin (4) $(2.0 \mathrm{~g}, 1.8 \mathrm{mmol})$ was used for the next step, and Boc-D-Pro-OH, Boc-Glu(OBn)-OH and Boc-Gly-OH were coupled to the resin successively using the standard protocol as described in Table 5. After removing Nterminal Boc group with $50 \%$ TFA, the resin was stirred in $15 \mathrm{~mL}$ acetic acid and $7 \mathrm{~mL}$, DIEA in $10 \mathrm{~mL}$ DCM. The success of the acetylation of the resin was again monitored by a Kaiser test. The resin was washed with DCM and dried in vacuo overnight.

(4) Preparation of Ac-Gly-Glu-D-Pro-Gly-Glu-D-Pro- $\mathrm{NH}_{2}$ (1)

In a Kel-HF reaction vessel, $1.5 \mathrm{~mL}$ of anisole was added along with $2.4 \mathrm{~g}$ of dried resin 5 and the resin was cleaved by anhydrous $\mathrm{HF}$ at $0{ }^{\circ} \mathrm{C}$. The solid was washed with ether to remove organic byproducts and anisole, and the cleaved peptide was extracted with $25 \%$ acetic acid. After lyophilization $570 \mathrm{mg}$ white powder was obtained. Yield: $48 \%$. 


\section{Synthesis of Ac-Gly-Glu(NHOH)-D-Pro-Gly-Glu(NHOH)-D-Pro-NH}

(1) Preparation of Fmoc-Gly-Glu(O-tBu)-D-Pro-Gly-Glu(O-tBu)-D-ProMBHA resin (6)

First, MBHA resin $(1 \mathrm{~g}, 1.2 \mathrm{mmol}$, substitution= $1.2 \mathrm{meq} / \mathrm{g})$ was swelled in DIEA/DCM: 1/9 overnight. Next, the different Fmoc amino acid building blocks, FmocD-Pro-OH (1.23 g, $3.6 \mathrm{mmol})$, Fmoc-Glu(tBu)-OH (1.53 g, $3.6 \mathrm{mmol})$, Fmoc-Gly-OH (1.07 g, $3.6 \mathrm{mmol})$, Fmoc-D-Pro-OH (1.23 g, $3.6 \mathrm{mmol})$, Fmoc-Glu(tBu)-OH (1.53 g, 3.6 mmol), Fmoc-Gly-OH (1.07 g, $3.6 \mathrm{mmol})$ were coupled to the resin one by one by following the Fmoc cycle as shown in Table 5. Reagents including BOP (1.53 g, 3.6 $\mathrm{mmol})$, HOBt $(0.49 \mathrm{~g}, 3.6 \mathrm{mmol})$ and DIEA $(1.26 \mathrm{~mL}, 7.2 \mathrm{mmol})$ were used in every coupling cycle for the condensation reaction.

(2). Preparation of Ac-Gly-Glu(O- $t$ Bu)-D-Pro-Gly-Glu(O- $t$ Bu)-D-Pro-MBHA $\operatorname{resin}(7)$

The N-terminal Fmoc protected hexapeptide resin 6 was treated with 25\% piperidine/DMF for $30 \mathrm{~min}$ followed by wash with $\mathrm{DMF}, \mathrm{MeOH}$ and DCM. The peptide was acetylated on its $\mathrm{N}$-terminus by shaking with $3.4 \mathrm{~mL}$ ( $36 \mathrm{mmol})$ acetic anhydride and $6.3 \mathrm{~mL}$ ( $36 \mathrm{mmol})$ DIEA in $20 \mathrm{~mL}$ DCM overnight.

(3). Preparation of Ac-Gly-Glu(NHOBn)-D-Pro-Gly-Glu(NHOBn)-D-ProMBHA resin (8)

Starting with the acetylated peptide resin 7 , the $t$-Butyl groups on the glutamic acid side chains were removed using three treatments of $30 \mathrm{~mL} 70 \%$ TFA (TFA/ $\mathrm{CH}_{2} \mathrm{Cl}_{2} /$ anisole: $70 / 25 / 5$ ) for 30 min each time. The resin was neutralized by using $10 \%$ DIEA/ $\mathrm{CH}_{2} \mathrm{Cl}_{2}(3 \times 1 \mathrm{~min})$ and washed with $\mathrm{DCM}$ and $\mathrm{MeOH}$. O- 
benzylhydroxylamine $(1.15 \mathrm{~g}, 7.2 \mathrm{mmol})$ was recovered from $\mathrm{NH}_{2} \mathrm{OBn} \bullet \mathrm{HCl}$ by stirring in DMF with DIEA (1.2 mL, $7.2 \mathrm{mmol})$. Coupling reagents BOP (3.19 g, $7.2 \mathrm{mmol})$, HOBt $(0.97 \mathrm{~g}, 7.2 \mathrm{mmol})$ and DIEA $(1.2 \mathrm{~mL}, 7.2 \mathrm{mmol})$ were added to the resin along with $\mathrm{NH}_{2} \mathrm{OBn}$ and the suspension was stirred for two hours. The resin was washed and dried in vacuo.

(4) Preparation of Ac-Gly-Glu(NHOH)-D-Pro-Gly-Glu(NHOH)-D-Pro- $\mathrm{NH}_{2}$

The dry hydroxamate peptide resin $\mathbf{8}$ was put into a Kel-F HF apparatus and stirred with $10 \mathrm{~mL}$ anhydrous $\mathrm{HF}$ and $0.05 \mathrm{~mL}$ anisole at $0{ }^{\circ} \mathrm{C}$ for $1 \mathrm{~h}$. $\mathrm{HF}$ was evaporated and the solid was washed with $20 \mathrm{~mL}$ ether three times. The resin was dried in air before the peptide was extracted with $25 \%$ acetic acid. The crude peptide (390 $\mathrm{mg}$ ) was obtained after lyophilization from aqueous acetic acid. The crude peptide was purified through a $\mathrm{C}-18$ column using a step gradient from $2 \%-8 \%$ acetonitrile at $2 \%$ increments and the desired product was eluted at $8 \%$ acetonitrile. Purified peptide ( 200 mg) was obtained, and it gave a positive hydroxamate test, changing $\mathrm{FeCl}_{3}$ solution from yellow to red. Yield: $28 \%$.

\section{General Procedure for Metal Binding Studies}

Individual metal binding test: The peptide and a metal perchlorate were mixed in $50 \mu \mathrm{l}$ deionized water to provide a 1: 1 equivalent $(0.6 \mu \mathrm{mol})$ solution. The aqueous solution was mixed with one equivalent acetonitrile and formic acid was added to adjust $\mathrm{pH}$ to 5 before it was applied directly to ESI-MS. The aqueous solution was mixed with $\alpha$-cyano-4-hydroxycinnamic acid matrix in water $(0.1 \% \mathrm{TFA})$ : acetonitrile (1:2) solution. 
Competition metal binding study: The peptide and metal perchlorate mixtures with the desired ratios were dissolved in $50 \mu$ deionized water in different equivalents according to the experimental needs. The aqueous solution was mixed with one equivalent acetonitrile and the $\mathrm{pH}$ value was adjusted to 5 by adding formic acid and the solution was applied directly to ESI-MS. 


\section{REFERENCES}

Aota, S., Nomizu, M. \& Yamada, K.M. (1994). The short amino acid sequence Pro-HisSer-Arg-Asn in human fibronection enhances cell-adhesive function. J. Biol. Chem. 269(40), 24756-24761

Baht, U., Deppe, A., Karas, M.,.Hillenkmamp, F. \& Giessmann, U. (1992). Mass spectrometry of synthetic polymers by UV-matrix-assisted laser desorption/ionization. Anal. Chem. 64(22), 2866- 2869

Barker, J. (1999). In Mass Spectrometry, New York: John Wiley \& Sons, NY

Barlaam, B., Koza, P. \& Berriot, J. (1999). Solid-phase synthesis of hydroxamic acid based TNF- $\alpha$ convertase inhibitors. Tetrahedron 55, 7221-7232

Beavis, R.C. \& Chait, B.T. (1990). High-accuracy molecular mass determination of proteins using matrix-assisted laser desorption mass spectrometry. Anal. Chem. 62(17), $1836-1840$

Blair, S.M., Kempen, E.C., Brodbelt, J.S. (1998). Determination of binding selectivities in host-guest complexation by electrospray/quadrupole ion trap mass spectrometry.J. Am. Soc, Mass Spectrom. 9(10), 1049-1059

Bodanszky, M. \& Martinez, J. (1978). Side Reactions in peptide synthesis IX. Suppression of the formation of aminosuccinyl peptides with additives. Int.J. Peptide Protein Res. 12(5), 277-83 
Brewer, D. \& Lajoie, G. (2000). Evaluation of the metal binding properties of the histidine-rich antimicrobial peptides histatin 3 and 5 by electrospray ionization mass spectrometry. Rapid Commun. Mass Spectrom. 14(19), 1736-1745.

Budzikiewicz, H. (2001). Siderophore-antibiotic conjugates used as trojan horses against Pseudomonas aeruginosa. Current Topics in Medicinal Chemistry. 1(1), 73-82.

Carpino, L.A. \& EI-Faham, A. (1995). Tetramethylfluroformamidinum hexafluorophosphate: a rapid-acting peptide coupling reagent for solution and solid phase peptide synthesis. J. Am. Chem. Soc. 117, 5401-5402.

Carrano, C.J., Drechsel, H., Kaiser, D., Jung, G., Matzanke, B., Winkelmann, G., Rochel, N. \& Albrecht-Gary, A. (1996). Coordination chemistry of the carboxylate type siderophore rhizoferrin: the iron(III) complex and its metal analogs. Inorg. Chem. $35,6429-6436$.

Chen, J.J, Teesch, L.M. \& Spatola, A.F. (1996). Using cyclic peptide mixtures as probes for metal ion host -guest interactions. Lett. Peptide Sci. 3, 17-24.

Chen, J.J. \& Spatola, A.F. (1997). Solid phase synthesis of peptide hydroxamic acids. Tetrahedron Lett. 38 (9), 1511-1514.

Clarke, T.E., Tari, L.W.\& Vogel, H. J. (2001). Structural biology of bacterial iron uptake systems. Curr. Top. Med. Chem. 11 (1), 7-30.

Cohen, S.L. \& Chait, B.T. (1996). Influence of matrix solution conditions on the MALDI-MS analysis of peptides and proteins. Anal. Chem. 68(1), 31-37.

Crumbliss, A.L. (1991). In CRC handbook of microbial iron chelates, Winkelmann, G. Ed., Boca Raton, USA: CRC Press., 177-233.

Drechsel, H. \& Jung, G (1998). Peptide Siderophores. J. Peptide Sci. 4, 147-181. 
Floyd, C.D., Lewis, C.N., Patel, S.R. \& Whittaker, M. (1996). A Method for the synthesis of hydroxamic acids on solid phase. Tetrahedron Lett. 37 (44), 8045-8048.

Furumai, R., Komatsu, Y., Nishino, N., Khochbin, S., Yoshida, M. \& Horinouchi, S. (2001). Potent histone deacetylase inhibitors built from trichostatin A and cyclic tetrapeptide antibiotics including trapoxin. Proc. Natl. Acad. Sci, 98(1): 87 - 92.

Goolsby, B.J., Brodbelt, J.S., Adou, E., Blanda, M. (1999). Determination of alkali metal ion binding selectivities of calixarenes by matrix-assisted laser desorption ionization and electrospray ionization in a quadrupole ion trap. Int. J. Mass Spectrom. $193(2 / 3)$, 197-204.

Grigg, R., Major, J.P., Martin, F.M. \& Whittaker, M. (1999). Solution and solid-phase synthesis of hydroxamic acids via palladium catalyzed cascade reactions. Tetrahedron Lett. 40, 7709-7711.

Harris, W.R., Carrano, C.J., Cooper, S.R., Sofen, S. R., Avdeef, A.E., McArdle, J.V., and Raymond, K.N., (1979). Isolation, characterization, and formation constants of ferric aerobactin.. J. Am. Chem. Soc. 101, 2722-2727.

Hojo, K., H., Susuki, Y., Maeda, M., Okazaki, I., Nomizu, M., Kamada, H., Yamamoto, Y., Nakagawa, S., Mayumi, T. and Kawasaki, K., (2001). Amino acids and peptide. part 39: a bivalent poly(ethyleneglycol) hybrid containing an active site (RGD) and its synergistic site (PHSRN) of fibronectin. Bioorg. \& Med. Chem. Lett. 11, 1429-1432.

Hou, Z., Raymond, KN, O'Sullivan, B. and Esker, T.W., (1998). A preorganized siderophore: Thermodynamic and structural characterization of Alcaligin and 
Bisucaberin, microbial macrocyclic dihydroxamate chelating agents. Inorg. Chem. $37,6630-6637$.

Hu, J. \& Miller, M.J. (1997). Total Synthesis of a Mycobactin S, a Siderophore and Growth Promoter of Mycobacterium Smegmatis, and Determination of its Growth Inhibitory Activity against Mycobacterium tuberculosis. J. Am. Chem. Soc. 119, $3462-3468$.

Hynes, R.O. 1990. In Fibronectins. New York: Springer-Verlag, NY

Johnson, RS, Martin, SA and Biemann, K. (1988). Collision-induced fragmentation of $(\mathrm{M}+\mathrm{H})^{+}$ions of peptides. Side chain specific sequence ions. Int. J. Mass Spectrom. Ion Processes 86, 137-154.

Jaquinod, M., Leize, E., Potier, N., Albrecht, A., Shanzer, A. \& Dorsselaer, A.V. (1993). Characterisation of non-covalent complexes by electrospray mass spectrometry Tetrahedron Lett. 34 (17), 2771-2774.

Jespersen, S., Niessen, W.M.A., Tjaden, U.R. \& Van der Greef, J. (1995). Quantitative bioanalysis using matrix-assisted laser desorption/ionization mass spectrometry. $J$. Mass Spectrom. 30 (2), 357-364.

Karlström, A. \& Undén, A. (1996). A new protecting group for aspartic acid that minimizes piperidine-catalyzed aspartimide formation in Fmoc solid phase peptide synthesis. Tetrahedron Lett. 37 (24), 4243-4246.

Karlström, A. \& Undén, A. (1995). The 2,4-dimethyl-3-pentyl ester as a new protecting group for aspartic acid that prevents base-catalyzed aspartimide formation in solid phase peptide synthesis. Tetrahedron Lett. 36(22), 3909-3912. 
Karas, M., Bahr, U., Ingendoh, A. \& Hillenkamp, F. (1989). Laser-desorption mass spectrometry of 100,000-250,000-Dalton proteins. Angew. Chem., Int. Ed. Engl. 101(6), 805-806.

Karas M., \& Hillenkamp, F. (1988). Laser desorption ionization of proteins with molecular masses exceeding 10,000 daltons. Anal. Chem. 60(20), 2299- 2301.

Karunaratne, V., Hoveyda, H.R. \& Orvig, C. (1992). General method for the synthesis of trishydroxamic acids. Tetrahedron Lett. 33 (14), 1827-1830.

Kornblihtt, A.R., Umezawa, K., Vibe, P.K. \& Baralle, F.E. (1985). Primary structure of human fibronectin: differential splicing may generate at least 10 polypeptides from a single gene. EMBOJ. 4(7), 1755-1759.

Krumme, D. \& Tschesche, H. (2002). Oxal Hydroxamic acid derivatives with inhibitory activity against matrix metalloproteinases. Bioorg. \& Med. Chem. Lett. 12, 933936.

Krumme, D., Wenzel, H. \& Tschesche, H. (1998). Hydroxamate derivatives of substrateanalogous peptides containing aminomalonic acid are potent inhibitors of matrix metalloproteinases. FEBS Lett. 436, 209-212.

Leahy, D.J., Aukhil, I. \& Erickson, H.P. (1996). $2.0 \AA$ crystal structure of a four-domain segment of human fibronectin encompassing the RGD loop and synergy region. Cell 84, 155-164.

Lippard, S. J. \& Berg, J. M. (1994). In Principles of bioinorganic chemistry. Principles Liu, Z.D. \& Hider, R.C. (2002). Design of clinically useful iron(III)-selective chelators. Medicinal Research Reviews 22 (1), 26-64. 
Livant, D.L., Brabec, R.K., Kurachi, K. Allen, D.L., Wu, Y. Haaseth, R, Andrews, P., Ethier, S. \& Markwart, S. (2000a). The PHSRN sequence induces extracellular matrix invasion and accelerates wound healing in obese diabetic mice. J. Clin. Invest. 105 (11), 1537-1545.

Livant, D.L., Brabec, R.K., Pienta, K.J., Allen, D.L, Kurachi, K., Makwart, S. \& Upadhyaya, A. (2000b). Anti-invasive, antitumorigenic, and antimetastatic activities of the PHSCN sequence in prostate carcinoma. Canc. Res. 60, 309-320.

Marshall, G.R., Reddy, P.A., Schall, O.F., Naik, A., Beusen, D.D., Ye, Y. \& Slomczynska, U. (2002). Combinatorial chemistry of metal-binding ligands. Advances in supramolecular chemistry. Gokel, G.W. Ed., St. Louis, MO, USA: Cerberus Press., 175-243.

Miller, M.J. (1989). Synthesis and therapeutic potential of hydroxamic acid based siderophores and analogues. Chem. Rev. 89, 1563-1579.

Mirgorodskaya, O.A., Kozmin, Y.P., Titov, M.I., Körner, R., Sönksen, C.P. \& Rospstorff, P. (2000). Quantitation of peptides and proteins by matrix-assisted laser desorption/ionization mass spectrometry using ${ }^{18} \mathrm{O}$-labeled internal standards. Rapid Commun. Mass Spectrom. 14, 1226-1232.

Miyamoto, S., Akiyama, S.K., \& Yamada, K.M. (1995). Synergistic roles for receptor occupancy and aggregation in integrin transmembrane function. Science 267 (5199), 883-885.

Neilands, J.B. (1995). Siderophores: structure and function of microbial iron transport compounds. J. Biol. Chem. 270 (45), 26723-26726. 
Ngoka, Lambert C.M. \& Gross, M.L. (2000). Location of alkali metal binding sites in endothelin A selective receptor antagonists, cyclo(D-Trp-D-Asp-Pro-D-Val-Leu) and cyclo(D-Trp-D-Asp-Prol-D-Ile-Leu), from multistep collisionally activated decompositions. J. Mass Spectrom. 35, 265-276.

Nikam, S, Kornberg, B., Johnson, D.R. \& Doherty, A.M. (1995). Synthesis of hydroxamic acids: $\mathrm{Pd} / \mathrm{BaSO}_{4}$ as a new catalyst for the deprotection of O-benzyl hydroxamates. Tetrahedron Lett. 36 (2), 197-200.

Offer, J., Quibell, M. \& Johnson, T. (1996). On-resin solid-phase synthesis of asparagines $\mathrm{N}$-linked glycopeptides: use of $\mathrm{N}$-(2-acetoxy-4-methoxybenzyl) (AcHmb) aspartyl amide-bond protection to prevent unwanted aspartimide formation. J. Chem. Soc., Perkin Trans. 1, 175-181.

Overberg, A., Hassengurger, A. \& Hillenkamp, F. (1992). in Mass Spectrometry in Biological Sciences: a Tutorial, edited by M. L. Gross, Kluwer, Dordrecht, 181197.

Pierschbacher, M.D., Ruoslahti, E. (1984). Cell attachment activity of fibronectin can be duplicated by small synthetic fragments of the molecule. Nature 309 (5963), 3033.

Pirrung, M.C. \& Chau, Joseph H.-L (1995). A convenient procedure for the preparation of amino acid hydroxamates from esters. J. Org. Chem. 60, 8084-8085.

Pollack, J.R. \& Neilands, J.B. (1970). Enterobactin, an iron transport compound from Salmonella typhimurim. Biochem. Biophys. Res. Commun. 38, 989-992. 
Porath, J., Carlsson, J., Olsson, I., Belfrage, G. (1975). Metal chelate affinity chromatography, a new approach to protein fractionation. Nature 258 (5536), 598-599.

Pramanik, B.N., Bartner, P.L., Mirza, U.A., Liu, Y. \& Ganguly, A.K. (1998). Electrospray Ionization Mass Spectrometry for the study of non-covalent complexes; an emerging technology.J. Mass Spectrom. 33, 911-920.

Przybylski, M. \& Gilocker, M.O. (1996). Electrospray mass spectrometry of biomacromolecular complexes with noncovalent interactions - new analytical perspectives for supramolecular chemistry and molecular recognition processes. Angew. Chem. Int. Ed. Engl. 35 (8), 806-826.

Rabanal, F., Pastor, J.J., Nicolas, E., Albericio, F. \& Giralt, E. (2000). Synthesis of aspartimide-free protected peptides on base-labile functionalized resins. Tetrahedron Lett. 41, 8093-8096.

Redick, S.D., Settles, D.L., Briscoe, G. \& Erickson, H.P. (2000). Defining fibronectin's cell adhesion synergy site by site-directed mutagenesis. J. Cell Biol. 149 (2), 521527.

Reid, R.T., Live, D.H., Faulkner, D.J. \& Bulter, A. (1993). A siderophore from a marine bacterium with an exceptional ferric ion affinity constant. Nature $366,455-458$.

Roepstorff, P. \& Fohlman, J. (1984). Proposal for a common nomenclature for sequence ions in mass spectra of peptides. Biomed Mass Spectrom, 11 (11), 601

Romanovskis, P. \& Spatola, A.F. (1998). Preparation of head-to-tail cyclic peptides via side chain attachment: implications for library synthesis. J. Peptide Res. 52, 356374. 
Shanzer, A. \& Libman, J. (1991). CRC handbook of microbial iron chelates, Winkelmann, G. Ed., Boca Raton, USA: CRC Press, 309-338.

Smith, M.J., Shoolery, J.N., Schwyn, B., Holden, I. \& Neilands, J.B. (1985). Rhizobactin, a structurally novel siderophore from Rhizobium meliloti. J. Am. Chem. Soc. 107, $1739-1743$.

Snow, G. A. (1970). Mycobactins: iron chelating growth factors from mycobacterium. Microbiol. Rev. 43, 99-125.

Snow, G. A. (1965). Isolation and structure of mycobactin T, a growth factor from Mycobacterium tuberculosis. Biochem. J. 97, 166-175.

Spatola, A.F., Darlak, K. Romanovskis, P. (1996). Cyclic Peptide Libraries: Reducing Epimerization in Medium Sized Rings During Solid Phase Synthesis. Tetrahedron Lett., 37, 591-594.

Stahl, B, Steup, M., Karas, M. \& Hillenkamp, F. (1991). Analysis of neutral oligosaccharides by matrix-assisted laser desorption ionization mass spectrometry. Anal. Chem. 63(14), 1463-1466.

Thiken, A.; Winkelmann, G. (1992). Rhizoferrin: a complexone type siderophore of the Mucorales and Entomophthorales (Zygomycetes). FEBS Microbiol. Lett, 73 (1-2), $37-41$.

Volz, J., Bosch, F., Wunderlin, M., Schuhmacher, M., Melchers, K., Bensch, K, Steinhilber, K., Schäfer, K., Tóth, G., Penke, B. \& Przybylski, M. (1998). Molecular characterization of metal-binding polypeptide domains by electrospray ionization mass spectrometry and metal chelate affinity chromatography. $J$. Chromatogr. A, 800(1), 29-37. 
Wade, J.D., Mathieu, M.N., Macris, M., Tregear, G.W. (2000). Base-induced side reactions in Fmoc-solid phase peptide synthesis: minimization by use of piperazine as $\mathrm{N}^{\alpha}$-deprotection reagent. Lett. Peptide Sci. 7(2), 107-112.

Yamada, K.M. (2000). Fibronectin peptides in cell migration and wound repair. J. Clin. Invest. 105 (11), 1507-1509.

Yokokawa, F., Izumi, K., Omata, J. \& Shioiri, T. (2000). Total synthesis of Amamistatin A, an antiproliferative linear peptide from an actinomycete. Tetrahedron 56(19), $3027-3034$. 


\section{APPENDIX}

\section{GLOSSARY OF ABBREVIATIONS}

\begin{tabular}{|c|c|}
\hline$\AA$ & angstrom \\
\hline $\mathrm{AA}$ & amino acid \\
\hline $\mathrm{AcHmb}$ & N-(2-acetoxyl-4-methoxybenzyl) \\
\hline $\mathrm{AcOH}$ & acetic acid \\
\hline Asp & aspartic acid \\
\hline Arg & arginine \\
\hline Asn & asparagine \\
\hline Asu & aminosuccinic acid \\
\hline Boc & $t$-butyloxycarbonyl \\
\hline BOP & $\begin{array}{l}\text { benzotrizaole-1-yl-oxy-tris-(dimethylamino) phosphonium } \\
\text { hexafluorophosphate }\end{array}$ \\
\hline $\mathrm{Bn}$ & benzyl \\
\hline $\mathrm{C}$ & cysteine \\
\hline CAD & collisionally activated decomposition \\
\hline $\mathrm{CC}$ & collision cell \\
\hline CID & collision induced dissociation \\
\hline $\mathrm{CHCl}_{3}$ & chloroform \\
\hline Cys & cysteine \\
\hline
\end{tabular}




\begin{tabular}{|c|c|}
\hline$\delta$ & chemical shift \\
\hline $\mathrm{D}$ & aspartic acid \\
\hline $\mathrm{Da}$ & dalton \\
\hline DCC & dicyclohexylcarbodiimide \\
\hline DCM & dichloromethane \\
\hline DIC & diisopropylcarbodiimde \\
\hline DIEA & diisopropylethylamine \\
\hline DMF & dimethylformamide \\
\hline EDC & 1-(3-Dimethylaminopropyl)-3-ethyl-carbodiimide hydrochloride \\
\hline ESI-MS & electrospray ionization-mass spectrometry \\
\hline EtOAc & ethyl acetate \\
\hline EtOH & ethanol \\
\hline $\mathrm{F}$ & phenylalanine \\
\hline $\mathrm{FeCl}_{3}$ & ferric chloride \\
\hline Fmoc & fluorenylmethoxycarbonyl \\
\hline $\mathrm{FmOH}$ & $\alpha$-fluorenylmethanol \\
\hline $\mathrm{FN}$ & fibronectin \\
\hline $\mathrm{g}$ & gram \\
\hline G & glycine \\
\hline Gln & glutamine \\
\hline Glu & glutamic acid \\
\hline Gly & glycine \\
\hline $\mathrm{h}$ & hour \\
\hline
\end{tabular}


histidine

$\mathrm{HBr} \quad$ hydrogen bromide

His histidine

HF hydrogen fluride

HMFS $\quad N$-[9-hydroxylmethyl]-2-fluorenyl]succinamic acid

HOBt 1-hydroxybenzotriazole monohydrate

HPLC high performance liquid chromatography

LD laser desorption

Leu leucine

m $\quad \operatorname{milli}\left(10^{-3}\right)$

$\mathrm{M} \quad \mathrm{mol} / \mathrm{L}(\mathrm{molar})$

meq milliequivalent per dry gram

MALDI-TOF MS Matrix Assisted Laser Desorption Ionization - Time of Flight Mass Spectrometry

MMP matrix metalloproteinase

$\mathrm{MeOH} \quad$ methanol

Mpe $\quad \beta$-3-methylpent-3-yl

$\mathrm{Mg} \quad$ milligram

$\min \quad$ minute

mmol millimolar

$\mathrm{N} \quad$ aparagine

$\mathrm{NaHCO}_{3} \quad$ sodium bicarbonate

$\mathrm{NaSO}_{4} \quad$ sodium sulfate 


\begin{tabular}{|c|c|}
\hline $\mathrm{n}-\mathrm{BuOH}$ & $n$-butanol \\
\hline NMR & nuclear magnetic resonance \\
\hline NTA & nitrilotriacetic acid \\
\hline $\mathrm{P}$ & proline \\
\hline $\mathrm{pH}$ & negative logarithm of hydrogen ion activity \\
\hline Phe & phenylalaine \\
\hline$p \mathrm{MBHA}$ & para-methylbenzhydrylamine \\
\hline Pro & proline \\
\hline $\mathrm{R}$ & arginine \\
\hline $\mathrm{RF}$ & radio frequency \\
\hline RP-HPLC & reverse phase-high performance liquid chromatorgraphy \\
\hline $\mathrm{Rt}$ & retention time \\
\hline $\mathrm{S}$ & serine \\
\hline SDS-PAGE & sodium dodecylsulfate-polyacrylamide gel electrophoresis \\
\hline Ser & serine \\
\hline SPPS & solid phase peptide synthesis \\
\hline$t-\mathrm{Bu}$ & tert-butyl \\
\hline TFA & trifluororacetic acid \\
\hline TFFH & tetramethylflurorformamidinum hexafluorophosphate \\
\hline THF & tetrahydrofuran \\
\hline TLC & thin layer chromatography \\
\hline Thr & theronine \\
\hline$\Gamma \mathrm{c}$ & toluenesulfonyl \\
\hline
\end{tabular}


tryosine

Xan

xanthenyl 


\title{
CURRICULUM VITAE
}

NAME: Yingchuan Susan Sun

\author{
ADDRESS: 11 Bertlee Dr \\ Huntington Station \\ NY, 11746
}

DOB: $\quad$ Tianjin, P.R.China - Nov 09, 1975

\author{
EDUCATION \\ \& TRAINING: $\quad$ B.S., Pharmacy \\ China Pharmaceutical University \\ 1993-1997
}

